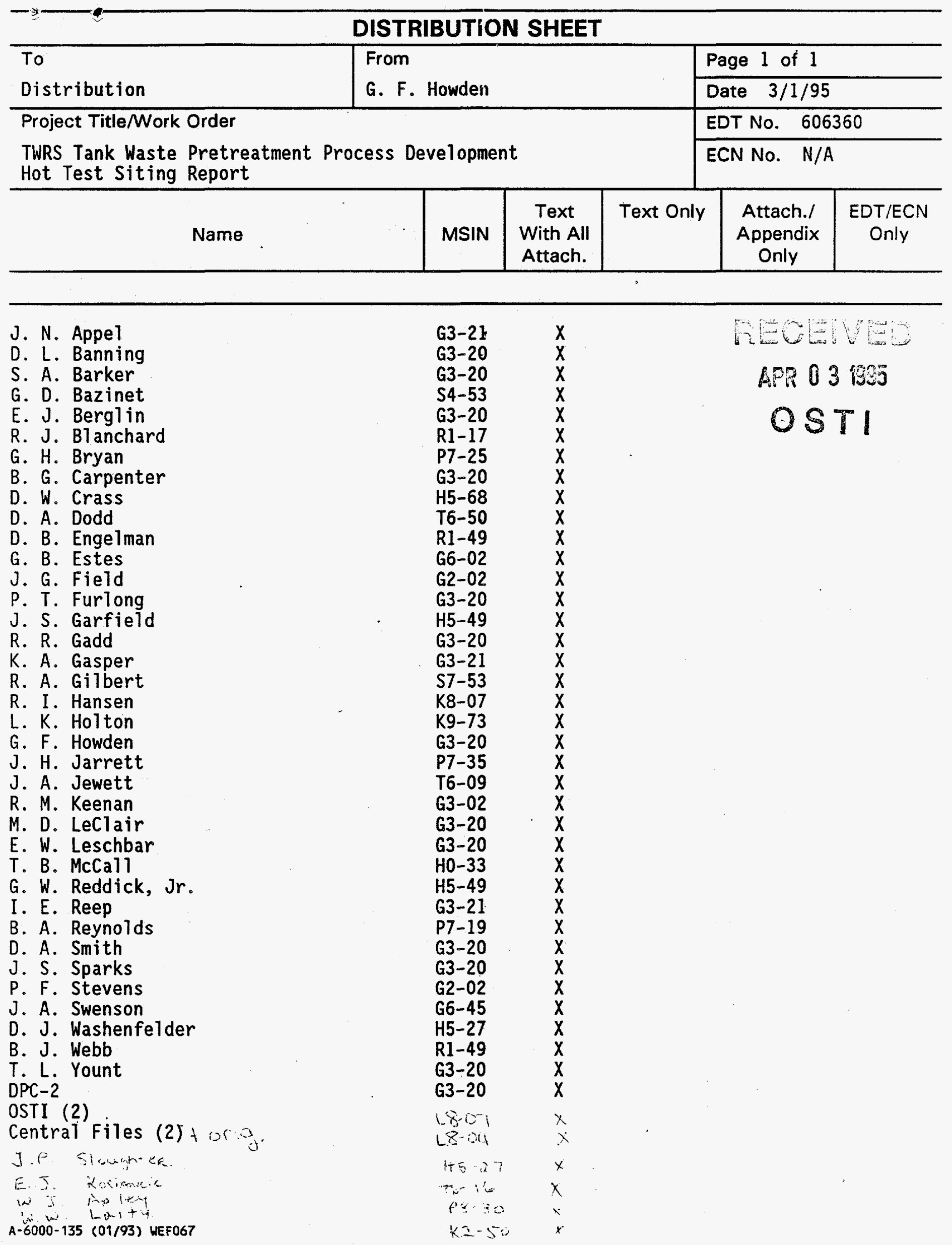




\section{DISCLAIMER}

Portions of this document may be illegible in electronic image products. Images are produced from the best available original document. 


\begin{tabular}{|l|l|}
\hline 2. To: (Receiving Organization) & 3. From: Coriginatin \\
IPM Project & IPM Program \& \\
\hline 5. Proj./Prog./Dept./Div.: & 6. Cog. Engr.: \\
IPM/TWRS & G. F. Howden \\
\hline
\end{tabular}

8. Originator Remarks:

Revised document is submitted for final approval of recommended facility allocations for performing hot test work, and sample retrieval infrastructure development to support the test program and Project design.

11. Receiver Remarks:

4. Related EDT No.:
604341
$\begin{gathered}\text { 7. Purchase Order No.: } \\ N / A\end{gathered}$
9. Equip./Component No.:
N/A

10. System/Bldg./Facility:

$N / A$

12. Major Assm. Dwg. No.: $N / A$

13. Permit/Permit Application No.: $N / A$

14. Required Response Date: $2 / 27 / 95$

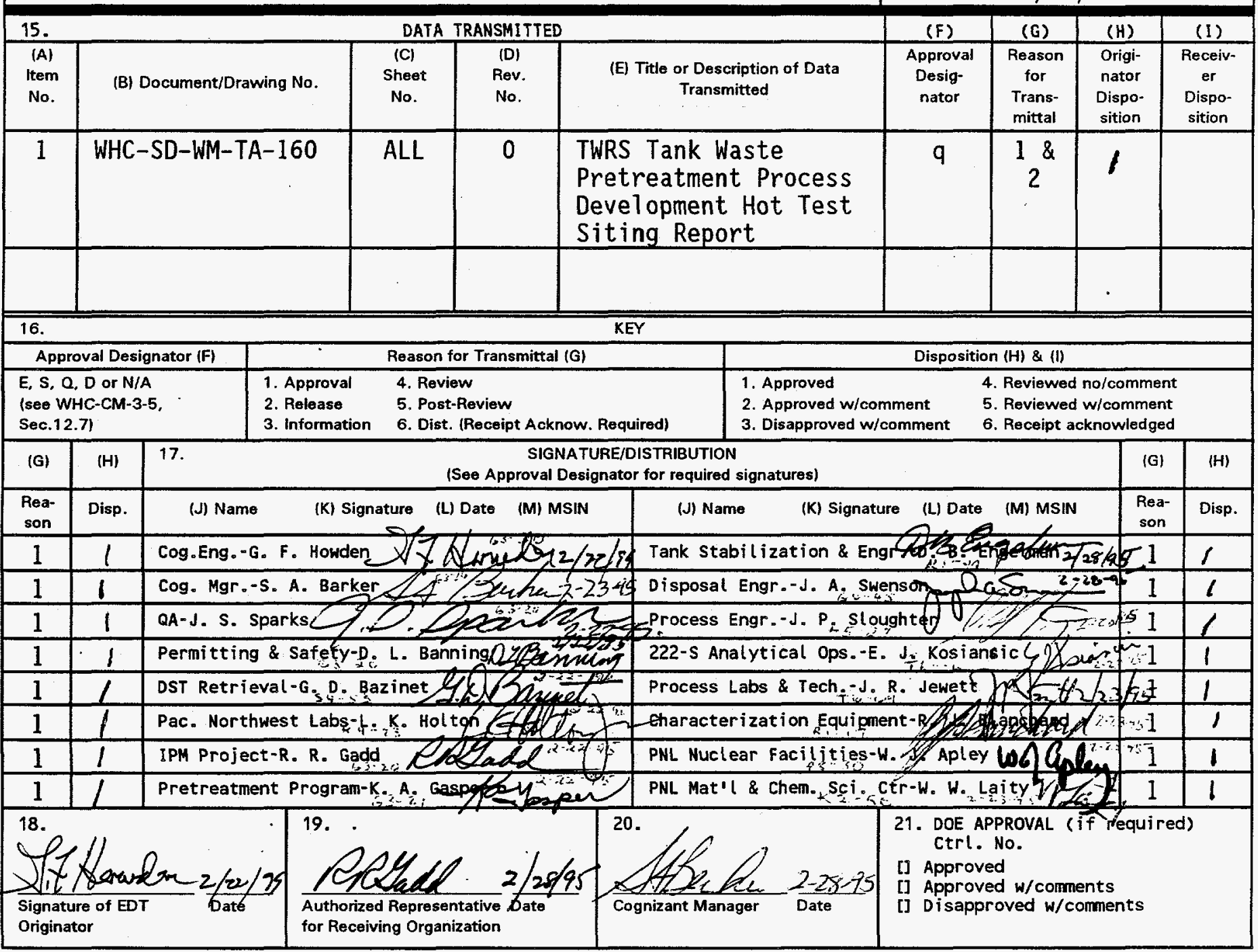




\section{WSTRUCTIONS FOR COMPLETION OF THE ENGINEERING DATA TRANSMITTAL (USE BLACK INK OR TYPE)}

\begin{tabular}{|c|c|}
\hline BLOCK & TITLE \\
\hline (1)* & EDT \\
\hline (2) & To: (Receiving Organization) \\
\hline (3) & From: (Originating Organization) \\
\hline (4) & Related EDT No. \\
\hline$(5)^{*}$ & Proj./Prog./Dept./Div. \\
\hline$(6)^{*}$ & Cognizant Enginear \\
\hline (7) & Purchase Order No. \\
\hline$(8)^{\circ}$ & Originator Remerks \\
\hline (9) & Equipment/Component No. \\
\hline (10) & System/Bidg./Facility \\
\hline (11) & Receiver Remerks \\
\hline (12) & Mejor Assm. Dwg. No. \\
\hline (13) & Pormit/Pormit Application No. \\
\hline (14) & Required Response Date \\
\hline
\end{tabular}

(15) Dete Trenamitted
(A)* Item Number
(B): Document/Drawing No.
(C)" Sheet No.
(D) Rov. No.
(E) Title or Description of Dats Transmitted
(F) Impact Lovel
(G) Reeson for Transmittel
(H) Originator Diaposition
(l) Receiver Disposition

(16) Key

(17) Signature/Oistribution
(G) Reason
(H) Disposition
(J) Name
(K) - Signeture
(L) - Date
(M) * MSIN

(18) Signeture of EDT Originator

(19) Authorized Representative for Receiving Organization

(20)* Cognizant Manager

(21)* DOE Approval
- Pro-essigned EDT number.

- Enter the individual's neme, title of the organization, or entity (e.g., Distribution) that the EDT is being transmitred to.

- Enter the title of the organization originating and tranemitting the EDT.

- Enter EOT numbers which relate to the data being tranamitted.

- Enter the Project/Progrem/Department/Division title or Project/Progrem acronym or Project Number, Work Order Number or Organization Code.

- Enter the neme of the individual identified as being responsible for coordinating dieposition of the EDT.

- Enter related Purchase Order (P.O.) Numbar, if availeble.

- Enter speciel of additional commonts concerning trensmittal, of "Key" retrieval words may be entered.

- Enter equipment/component number of affected item, if appropriate.

- Enter appropriate system, building or facility number, if appropriate.

- Entor spocial of additional commente concerning transmittal.

- Enter applicable drawing number of major assembly, if appropriate.

- Enter applicable permit or permit application number, if appropriate.

- Enter the dete a response is required from individuels identified in Block 17 (Signature/Distribution).

- Enter sequential number, beginning with 1, of the information listed on EDT.

- Enter the unique identification number assigned to the document of drawing being trensmitted.

- Enter the sheet number of the information being transmitted. If no sheet number, leave blank.

- Enter the revision number of the information being transmitted. If no revision number, leave blank.

- Enter the title of the document or drewing or a brief description of the subject if no title is identified.

- Enter the appropriate Impact Level (Block 15). Also, indicate the appropriate approvels for oach item listed, i.e. SQ, ESQ, etc. Use NA for non-engineering documents.

- Enter the eppropriate code to identify the purpose of the date transmittal (see Block 16 ).

- Enter the eppropriate disposition code (see Block 16).

- Enter the appropriate disposition code (see Block 16 ).

- Number codes used in completion of Blocks 15 (G), (H), and (I), and 17 (G), (H) (Signature/Distribution).

- Enter the code of the raeson for tranamittal (Biock 16).

- Enter the code for the dieposition (Block 16).

- Enter the signature of the individual completing the Disposition $17(H)$ and the Transmittal.

- Obtain appropriate sionoture(8).

- Enter date signature is obteined.

- Enter MSIN. Note: If Distribution Sheot is used, show entire distribution fincluding that indicated on Page 1 of the EDT) on the Distribution Sheot.

- Enter the signature and date of the individual originating the EDT (entered prior to tranamittal to Receiving Orgenizationj. If the EDT originator is the cognizant engineer, sign both Blocks 17 and 18 .

- Enter the signature and date of the individual identified by the Receiving Organizetion as authorized to approve disposition of the EDT and acceptence of the date tranamitted, as applicable.

- Enter the signature and date of the cognizant managor. (This signature is authorization for release.)

- Enter DOE epprovel (if required) by letter mumber and indicate DOE action.

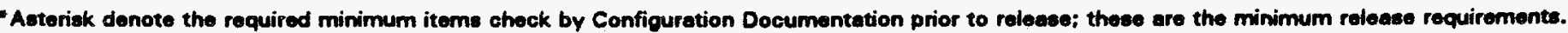




\section{RELEASE AUTHORIZATION}

Document Number: WHC-SD-WM-TA-160, Rev. 0

$\begin{array}{ll}\text { Document Title: } & T \text { Tank Waste Remediation-System-Tank Waste } \\ & \text { Pretreatment Process Development Hot Test Siting } \\ \text { Report }\end{array}$

Release Date: $\quad 3 / 07 / 95$

This document was reviewed following the procedures described in WHC-CM-3-4 and is:

APPROVED FOR PUBLIC RELEASE

WHC Information Release Administration Specialist:
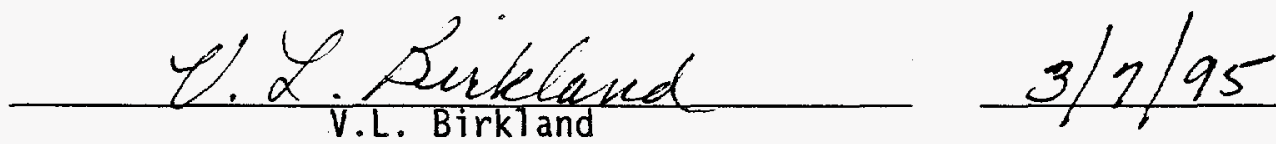

TRADEMARK DISCLAIMER. Reference herein to any specific commercial product, process, or service by trade name, trademark, manufacturer, or otherwise, does not necessarily constitute or imply its endorsement, recommendation, or favoring by the United States Government or any agency thereof or its contractors or subcontractors.

This report has been reproduced from the best available copy. Available in paper copy and microfiche. Printed in the United States of America. Available to the U.S. Department of Energy and its contractors from:

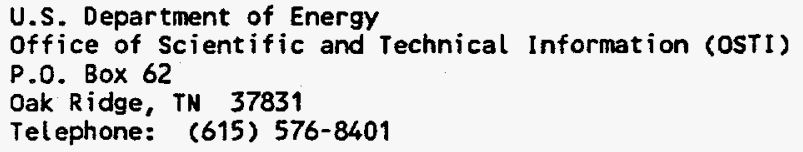

U.S. Department of Commerce National Technical Information Service (NTIS) 5285 Port Royal Road

Springfield, VA 22161

Telephone: (703) 487-4650 


\begin{tabular}{|l|l|c|}
\hline $\begin{array}{l}\text { 2. Title } \\
\text { TWRS Tank Waste Pretreatment Process Development } \\
\text { Hot Test Siting Report }\end{array}$ & WHC-SD-WM-TA-160 & 4. Rev No. \\
\hline $\left.\begin{array}{l}\text { 5. Key Words } \\
\begin{array}{l}\text { Test facilities, test requirements, testing } \\
\text { support, testing infrastructure, hot test, actual } \\
\text { waste, tank waste, pretreatment, IPM Project, } \\
\text { initial pretreatment module, pretreatment, } \\
\text { pretreatment process testing. }\end{array}\end{array}\right)$ 6. Author \\
\hline
\end{tabular}

\section{Abstract}

This report is the sixth in a series that have assessed the hot testing requirements for TWRS pretreatment process development and identified the hot testing support requirements. This report, based on the previous work, identifies specific hot test work packages, matches those packages to specific hot cell facilities, and provides recommendations of specific facilities to be employed for the pretreatment hot test work. Also identified are serious limitations in the tank waste sample retrieval and handling infrastructure. Recommendations are provided for staged development of 500 $\mathrm{mL}, 3 \mathrm{~L}, 25 \mathrm{~L}$ and $4000 \mathrm{~L}$ sample recovery systems and specific actions to provide those capabilities.

8. RELEASE STAMP

OFFICIAL.RELEASE BY VHC

DATE MAR 071995

35 
WHC-SD-WM-TA-160

Revision 0

\title{
TANK WASTE REMEDIATION SYSTEM TANK WASTE PRETREATMENT PROCESS DEVELOPMENT HOT TEST SITING REPORT
}

\author{
G. F. Howden \\ D. L. Banning \\ D. A. Dodd \\ D. A. Smith \\ P. F. Stevens \\ Westinghouse Hanford Company \\ R. I. Hansen \\ B. A. Reynolds \\ Pacific Northwest Laboratory
}

February 1995

\section{DISCLAIMER}

\begin{abstract}
This report was prepared as an account of work sponsored by an agency of the United States Government. Neither the United States Government nor any agency thereof, nor any of their employees, makes any warranty, express or implied, or assumes any legal liability or responsibility for the accuracy, completeness, or usefulness of any information, apparatus, product, or process disclosed, or represents that its use would not infringe privately owned rights. Reference herein to any specific commercial product, process, or service by trade name, trademark, manufacturer, or otherwise does not necessarily constitute or imply its endorsement, recommendation, or favoring by the United States Government or any agency thereof. The views and opinions of authors expressed herein do not necessarily state or reflect those of the United States Government or any agency thereof.
\end{abstract}


WHC-SD-WM-TA-160

Revision 0

\section{ACKNOWLEDGMENT}

The extra commitment and effort that was provided by the following Westinghouse Hanford Company (WHC) and Pacific Northwest Laboratory (PNL) staff in developing strategies, conducting field evaluations, preparing and processing large amounts of data, and writing this report have been invaluable, and are acknowledged with deep appreciation:

D. A. Dodd, WHC

B. A. Reynolds, PNL

P. A. Ombrellaro, WHC

R. I. Hansen, PNL.

The supporting efforts of the following WHC staff in site evaluations and preparation of data for this report are also acknowledged with appreciation:

D. L. Banning

P. F. Stevens

D. A. Smith

J. S. Sparks

C. R. Stroup. 


\section{EXECUTIVE SUMMARY}

The Tank Waste Remediation System pretreatment and treatment missions require extensive testing of processes and equipment to qualify them for use in the production facility designs.

In January 1994, the pretreatment facility project, known as Project $W-236 B$, Initial Pretreatment Module, began an investigation to identify the types and amount of testing that would be needed to support the project design work. The objective was to determine the availability of existing facilities to perform the hot test work, and the infrastructure (sampling, casks, staff, etc.) to support the testing.

This report is the sixth in a series that have defined the major issues requiring testing and the needed strategies and capabilities to resolve those issues. The study considered a full spectrum of possible pretreatment testing and used test scaling that should bound the actual testing required. The report's recommendations are based on technical and schedular considerations. Because planning of the detailed pretreatment tests is incomplete at this time, the study did not attempt to make cost trade-off assessments for siting of the test work. The detailed test plans and final space allocations will be shaped by test specific cost considerations.

This report identifies groups of issues requiring testing for resolution and matches them to Hanford site and offsite hot cell space.

Recommended siting for the test work is as follows:

Building number
$325 A$
$325 B$
324 Radiochemical
Engineering
324 Shielded
Materials Facility
$222-5$
$222-5$
$222-5$
Los Alamos National
Laboratory

\section{Building number} Laboratory

\section{Cel1 \\ $A+B+C$}

SAL

D

East

$1 F$

IIA

IEI

Wing 9

\section{Test description}

Ion-exchange testing with 10to $45-\mathrm{mL}$ columns with provision for 200-mL columns, if required

Settle/decant tests

Transuranic monitor tests

Filtration tests

Centrifugation tests

Organic defunctionalization

Ion-exchange tests, $S r, T c$ and TRU

Sludge wash tests 


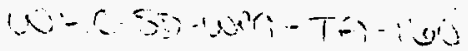

$$
\begin{aligned}
& \text { kich }
\end{aligned}
$$

This report also identifies a significant deficiency in infrastructure to recover and handle needed actual tank waste samples in the 1- to 4,000-L/sample size range. Because of the time needed to develop increasingly larger sample retrieval capabilities, interim cold test data and smaller scale hot test data will be employed to help validate assumptions made by the Architect-Engineer during conceptual and early definitive design work.

Recommended are actions needed for staged development of the sample retrieval capability, such that the current scale of hot testing can be escalated as the sample retrieval capability increases.

An early calendar year 1995 commitment of resources is needed to develop the tank waste sample retrieval and handling equipment and infrastructure in the $500 \mathrm{~mL}, 3 \mathrm{~L}, 25 \mathrm{~L}$ and 100 to $4000 \mathrm{~L}$ capability to support the required testing schedule.

The 100 to 4000 L capability is based on utilizing a 4000 liter shielded transporter vehicle currently being procured by Waste Tank Plant Engineering as a means of emergency removal of liquids from a leaking single shell tank. It's pretreatment test support mission will be retrieval and transportation of a number of supernatant and slurry samples in the 100 to $500 \mathrm{~L}$ range and return of test effluents to the tank farms. If required by future test plans, it would also provide the capability to handle larger samples. Some Program investment will be required for a portable load/unload capability at the tank farms and fixed unloading facilities at the test facilities. A further analysis of the testing need for the larger samples $(\geq 100 \mathrm{~L})$ and the risk of not performing those tests is planned before procurement of equipment for this system.

It is also recommended that the 324 Building, radiochemical engineering Cel1 $C$ be outfitted to receive the 25-L sampler cask and perform those functions to recover the sample for transhipment to the user and service the sampler for reuse. The 222-S Laboratory will provide equivalent service for the 500-mL and $3-L$ samplers. 
WHC-SD-WM-TA-160

Revision 0

\section{CONTENTS}

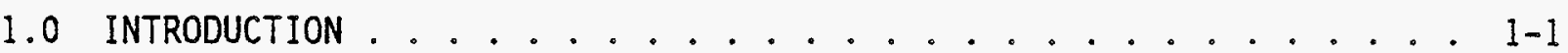

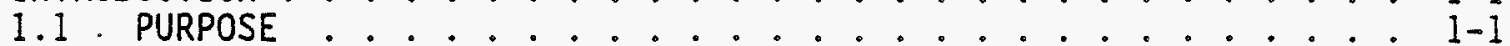

1.2 TECHNICAL BASIS .................. . . . $1-2$

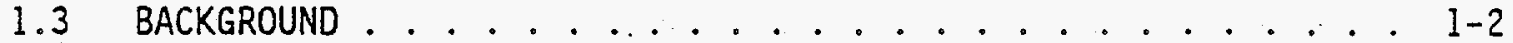

1.4 CURRENT STATUS ....................... 1 . .

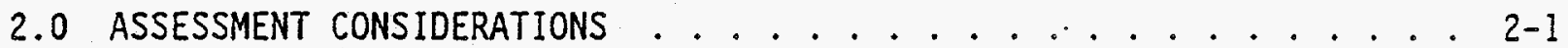

2.1 NEEDED SAMPLE SIZES, QUANTITY, AND TIMING ......... . . 2-1

2.2 PRESENT SAMPLE RETRIEVAL SIZE AND QUANTITY CAPABILITY . . . . 2-6

2.3 EXPANDED SAMPLING CAPABILITY WITHIN CY $1995 \ldots \ldots$. . . . . . . . 2-6

2.4 EXPANDED SAMPLING CAPABILITY - 18-MONTH SCHEDULE . . . . . . 2-7

2.5 SAMPLE TRANSPORTATION CASK AVAILABILITY ......... . 2-8

2.6 SAMPLE TRANSHIPMENT CAPABILITY .............. . 2-10

2.7 SAFETY DOCUMENTATION AND ENVIRONMENTAL PERMITTING . . . . . $2-11$

2.7.1 Safety Documentation . . . . . . . . . . . . . 2-11

2.7.2 National Environmental Policy Act of 1969

Documentation ............... 2-12

2.7.3 Resource Conservation and Recovery Act of 1976

Permitting ................ 2-12

2.7.4 Air Permits . . . . . . . . . . . . . . . . 2-13

2.8 CELL ACCESSIBILITY ON THE HANFORD SITE . . . . . . . . . 2-13

2.9 OTHER SITING CONSIDERATIONS . . . . . . . . . . . . . . 2-14

2.10 QUALITY ASSURANCE PROGRAM REVIEW . . . . . . . . . . . . 2-15

3.0 SITE EVALUATION METHODOLOGY SUMMARY . . . . . . . . . . . . . $3-1$

4.0 CONCLUSIONS AND DISCUSSION ....................... . . . . . . .

4.1 SITE/FACILITY RANKING METHODOLOGY . . . . . . . . . . . 4-1

4.2 FACILITY RANKINGS . . . . . . . . . . . . . . 4-1

4.3 TEST GROUP SITING RECOMMENDATIONS . . . . . . . . . . . . 4-1

4.3.1 Logic Exceptions . . . . . . . . . . . . . . . 4-14

4.3.2 Ion-Exchange Testing ............. 4-17

4.3.3 Filtration ............... . 4-17

4.3.4 Centrifugation and Filtration Testing ...... 4-17

4.3.5 Ion-Exchange Case 1 Group 2 Testing ........ . 4-18

4.3.6 Organic Defunctionalization Testing . . . . . . . . . 4-18

4.3.7 Settle/Decant Testing . . . . . . . . . . . . 4-18

4.3.8 Sludge Washing Tests ............. . 4-18

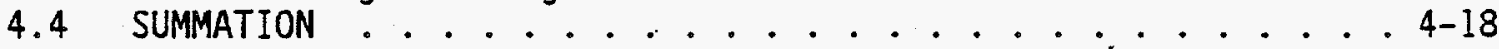

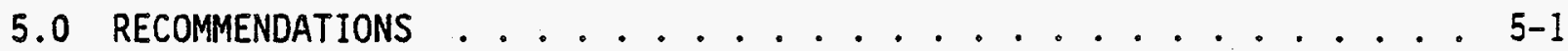

5.1 HOT CELL FACILITIES ................... . . . . . $5-1$

5.2 PERMITTING AND SAFETY ................ . . 5-2

5.3 RETRIEVAL EQUIPMENT, $<3 L$. . . . . . . . . . . . . . 5-2

5.4 RETRIEVAL EQUIPMENT, $25 \mathrm{~L} . . . . . . . . . . . .55-2$

5.5 RETRIEVAL EQUIPMENT, $100 \mathrm{~L}$ TO $4000 \mathrm{~L} \ldots \ldots 5-2$

5.6 TEST PLANNING .................. $5-3$

6.0 REFERENCES ........................ 6-1

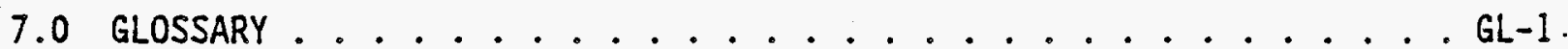




\section{WHC-SD-WM-TA-160 \\ Revision 0 \\ CONTENTS (cont)}

\section{APPENDIXES}

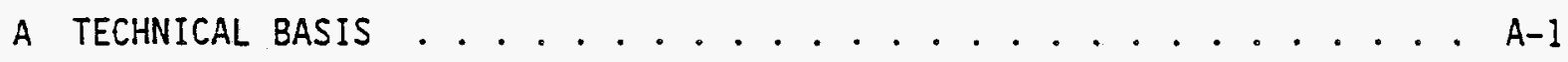

B HOT TESTING ISSUE DEFINITIONS AND GROUPING ........... B-1

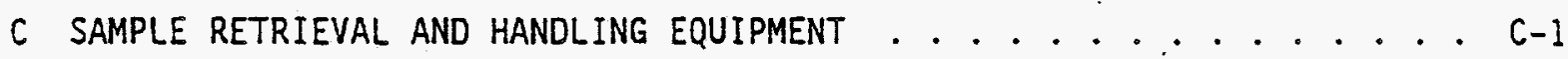

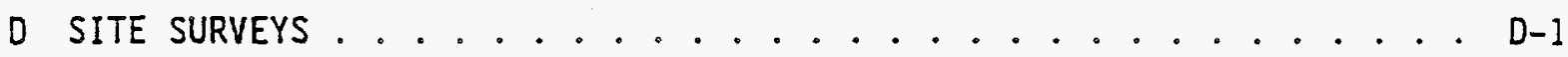

E SITE SURVEY ANALYSIS DATA ...................... E-1

F DECISION ANALYSIS METHODOLOGY AND SAMPLES ........... F-1

G RECORD OF KEY MEMORANDUMS ...................... . . . . . . 


\section{LIST OF FIGURES}

1-1 Investigative Study Process Block Diagram . . . . . . . . . . 1-3

2-1 Pretreatment Testing Waste Sample Requirements--Ion-Exchange Case 2 . . . . . . . . . . . . . . . . . . 2-2

2-2 Pretreatment Testing Waste Sample Requirements--Ion-Exchange Case I...................... 2-3

2-3 Pretreatment Testing Waste Sample Requirements--Ion-Exchange Case 2A..................... 2- . . . . . . . .

2-4 Pretreatment Testing Waste Sample Requirements--Ion-Exchange Case IA . . . . . . . . . . . . . . . . . . 2-5

4-1 Ranking of Hot Cells for Ion-Exchange 1-1........... . 4-3

4-2 Ranking of Hot Cells for Ion-Exchange 1-2........... 4-4

4-3 Ranking of Hot Cells for Ion-Exchange 2-1........... . 4-5

4-4 Ranking of Hot Cells for Sludge Wash Group 1 . . . . . . . . . . 4-6

4-5 Ranking of Hot Cells for STudge Wash Group 3 . . . . . . . . . 4-7

4-6 Ranking of Hot Cells for Sludge Wash Group 4 . . . . . . . . . . 4-8

4-7 Ranking of Hot Cells for Organic Destruction Group 1 . . . . . 4-9

4-8 Ranking of Hot Cells for Settle/Decant-1 . . . . . . . . . 4-10

4-9 Ranking of Hot Cells for Filtration Group 1 ........... . 4-11

4-10 Ranking of Hot Cells for Filtration Group 2.......... 4-12

4-11 Ranking of Hot Cells for Filtration Group 3 .......... 4-13

4-12 Ranking of Hot Cells for Centrifugation .......... 4-14 
WHC-SD-WM-TA-160

Revision 0

\section{LIST OF TABLES}

2-1 Fiscal Year 1995 Planned Large-Volume Sample Retrieval

Schedule - November 30, 1994 . . . . . . . . . . . . 2-7

2-2 Cask Descriptions ................... . . 2-9

2-3 Cask Capabilities for use at the Hanford Site. . . . . . . . 2-10

4-1 Facility Rankings................... . . 4-2

4-2 Test Group Siting Recommendations................4-15 
WHC-SD-WM-TA-160

Revision 0

\section{TANK WASTE REMEDIATION SYSTEM TANK WASTE PRETREATMENT PROCESS DEVELOPMENT HOT TEST SITING REPORT}

\subsection{INTRODUCTION}

Hanford Site tank waste will be pretreated to separate the low- and high-level fractions. The low-level waste (LLW) fraction, containing the bulk of the chemical constituents, must be processed into a vitrified waste product that will be disposed of onsite in accordance with current safety and environmental policy. The residual high-level waste (HLW) fraction from supernatant pretreatment (mainly cesium) will be combined with the HLW fraction from pretreatment of the tank sludges and solids, and immobilized as glass for disposal at a federal repository. Design of the tank waste sludge wash and solid/liquid separation functions, and the pretreatment facility (Project $W-236 B$, Initial Pretreatment Module [IPM]), requires facilities and support infrastructure to perform developmenta] and performance testing.

\subsection{PURPOSE}

The purpose of this report is to identify the hot testing capabilities available to support the design of the sludge washing, solid liquid separation, and pretreatment processes and facilities. This document will al so identify infrastructure development critically needed to support the testing programs.

This report is based on a study that investigated the availability and capabilities of hot laboratory facilities, hot cell facilities, and supporting infrastructure on U.S. Department of Energy (DOE) sites to perform the hot testing that was identified for the Tank Waste Remediation System (TWRS) solids/liquids separation and pretreatment functions (Howden 1994). The study also identified logical groupings of the tests needed to resolve 49 known open issues, and recommended candidate facilities and sites for performing the test work packages.

This report is the sixth in a series of coordinated reports that provide the following information.

- Broadly examined the testing needs of the pretreatment and vitrification functions (Howden 1994). This report identified and cataloged a number of issues for each pretreatment technology and for LLW vitrification. Each issue was one question that required varying combinations of cold or cold and hot testing to resolve and provide pretreatment facility design information. (In the following text, the sludge washing, solids/liquids separation, and radionuclide removal functions to supply feed to the low-level vitrification plant are generically referred to as "pretreatment.")

- Evaluated pretreatment test facility requirements and strategies (Reynolds 1994a). This report amplified the data on the 49 
WHC-SD-WM-TA-160

Revision 0

pretreatment issues provided by WHC-SD-WM-TA-156 (Howden 1994) and

incorporated test information need dates provided by the

pretreatment project's Architect-Engineer (A-E).

- Provided specific functional requirements for pretreatment hot testing facilities and sites (Reynolds 1994b). This report extracted from (Reynolds 1994a) information on the characteristics needed in hot test laboratories and hot cells and provided the basis for evaluating existing hot cell facilities in the DOE complex to do the required pretreatment test work.

- Provided criteria for evaluation of candidate hot test facilities and sites (Reynolds 1994c). This report developed spreadsheets for evaluating candidate hot cells for pretreatment testing.

- Provided an overall strategy for meeting the pretreatment facility design testing requirements, and the greater testing requirements for vitrification facility design, pretreatment, and vitrification facilities startup and operational support (Reddick 1994).

- This report documents the evaluation of candidate pretreatment testing sites and provides recommendations on the siting of test packages. This report also identifies facility and infrastructure upgrades critically needed to support the test work.

Figure 1-1 provides a block diagram of the investigative process that was employed during calendar year (CY) 1994 to develop this report and the other reports previously listed.

\subsection{TECHNICAL BASIS}

The basis for this and preceding parts of this study is the TWRS Pretreatment Program technical strategy as developed by Westinghouse Hanford Company (WHC) and the U.S. Department of Energy, Richland Operations Office (RL) (Appendix A-1). Appendixes A-2 and A-3 scope the volume of tank waste samples needed for testing, and the space requirements for ion-exchange work. For this assessment, 10- to 45- $\mathrm{mL}$ and $200-\mathrm{mL}$ ion-exchange column sizes were the assumed bounding requirements.

\subsection{BACKGROUND}

In January 1992, the first assessment was initiated to determine the need for additional hot test facilities and infrastructure to support TWRS tank waste pretreatment and immobilization process development. That work cuiminated in March 1993 with a report (Howden 1993) that surveyed the hot cells on the Hanford Site and assessed their suitability for a long-range hot testing support mission.

In March 1993; a recommendation was sent to RL (Hansrote 1993) to support immediate engineering work on development of a hot test facility and supporting infrastructure. The uncertainty about the TWRS technical approach resulting from the impending 1993 Tri-Party Agreement renegotiation (which 
WHC-SD-WM-TA- 160

Revision 0

Figure 1-1. Investigative Study Process Block Diagram.

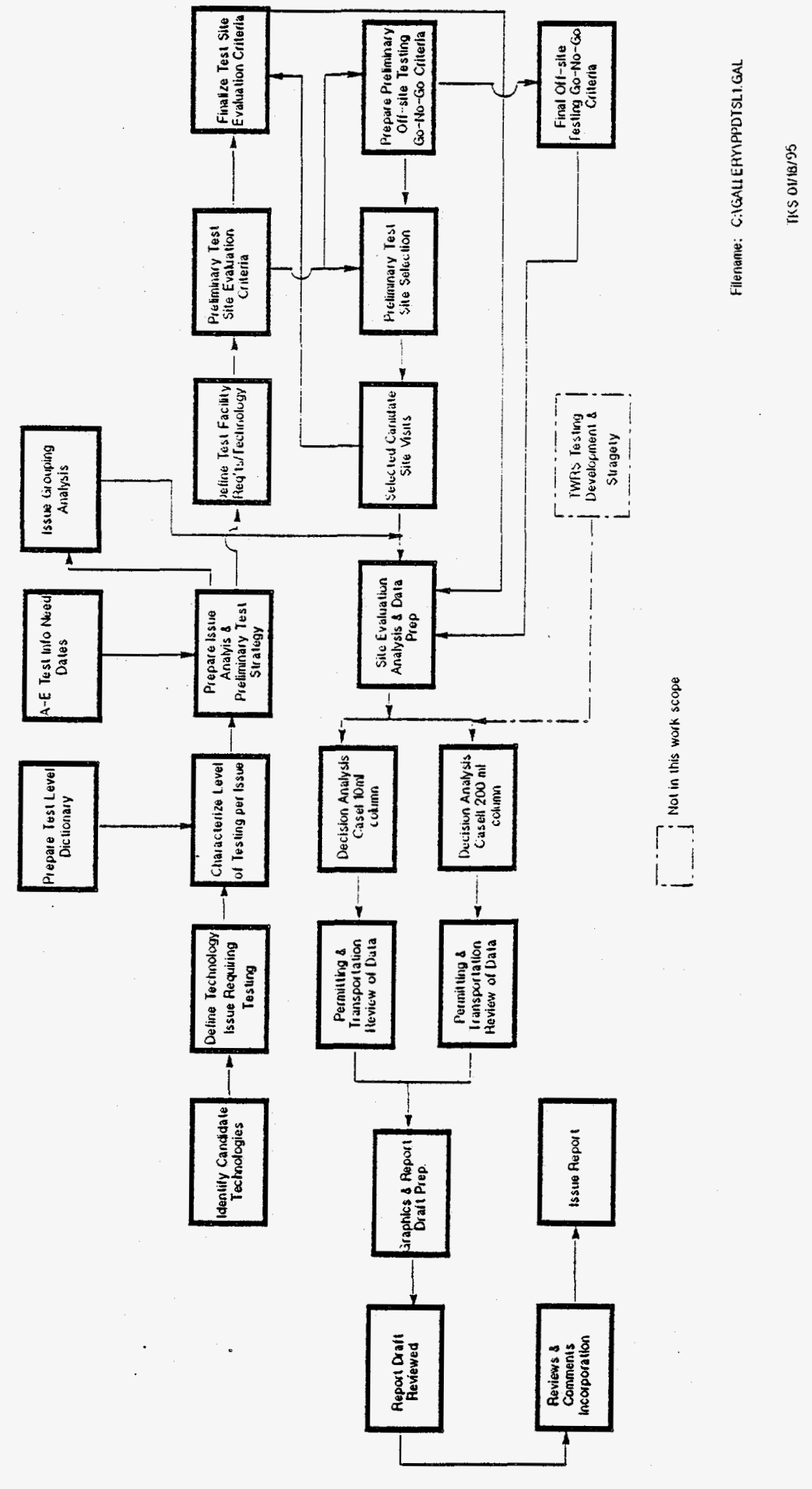


WHC-SD-WM-TA-160

Revision 0

began shortly thereafter) resulted in a decision to delay proceeding with the development of a hot test facility until a new technical strategy for waste tank remediation and disposition was established.

The fourth amendment to the Hanford Federal Facjijty Agreement and Consent Order (al so known as the Tri-Party Agreement [Ecology et al. 1994]), as approved by the stakeholder representatives in January 1994, significantiy redirected and expanded the previous Hanford Site cleanup goals and objectives to add the single-shell tanks (SST) to the work scope and redirect the disposition of LLW from a grout form to a vitrified glass waste form. With the signing of the revised Tri-Party Agreement in January 1994, this study was initiated by the TWRS Projects Department to redevelop an understanding of the technology issues and process development testing support needs of the newly revised technical strategy (Alumkal 1994) based on the revised Tri-Party Agreement.

\subsection{CURRENT STATUS}

There is adequate cold laboratory and other testing space at the Hanford Site and other national laboratories to support laboratory-scale pretreatment and vitrification process development test work, and larger-scale cold testing. There is, however, limited immediately available hot cell space for hot laboratory-, hot bench-, and larger-scale unit or integrated process testing with actual waste. Most of the available cell space falls into one of the following categories:

- Cannot be supplied with sufficient volumes of actual tank waste to perform the identified testing

- Must be cleaned out and refurbished

- Has never been used (Fuels and Materials Examination Facility [FMEF] at the Hanford Site) and must be outfitted.

Some of the hot cell space discussed in this document is in buildings that have little or no mission and are identified for DOE's decontamination and decommissioning program (Argonne National Laboratory-E, Building 200; Oak Ridge National Laboratory, Buildings 3047 and 3517) unless gainful1y utilized. A number of cells considered and discussed are in facilities partially committed to other missions. Finally, some hot cell space that was considered that will not be discussed further has been committed to other missions (Savannah River Laboratory and Sandia National Laboratory) or is already being decontaminated and decommissioned (Lawrence Livermore National Laboratory).

The current scale of hot testing is limited by the infrastructure to retrieve and handle actual tank waste samples. As of this writing, sampling capability is limited to $250-\mathrm{mL}$ samples of supernate, sludge, or salt cake using a coring sample system, and a 100-mL supernate and soft sludge "grab" sampling capability. There is no actual waste sampling capability or handling infrastructure to support the larger bench-scale testing needs of the TWRS disposal program. Work on this critical area is funded for fiscal year (FY) 1995 and outyears, however. Experience indicates that 12 to 24 months 
will be required (on receipt of funding) to develop needed 3-, 25-, and 4,000-L sampling infrastructures (equipment, facility modifications, trained staff, procedures, and permits) to support many of the tests assessed by this study. In the meantime, the testing can proceed but will be 1 imited in scope by the existing retrieval capability, which with extraordinary effort will be able to provide only a few liter size samples per year.

Most of the testing needed to provide meaningful input to the design of the IPM must be accomplished in the next 3 years. To meet this need, and considering the (approximately) 2- to 5-year lead time required to finance and construct new testing facilities and infrastructure, this study has focused on using existing capabilities at DOE sites and identifying the need for upgrades to enable their use.

A separate document will define the testing facility and infrastructure requirements to support the testing strategy outTined in WHC-SD-WM-SP-OOG, Testing and Development Strategy for the Tank Waste Remediation System (Reddick 1994) for the low- and high-level vitrification facility designs, and the startup testing needs of all three facilities. 
WHC-SD-WM-TA-160

Revision 0

This page intentionally left blank. 


\subsection{ASSESSMENT CONSIDERATIONS}

As briefly discussed earlier, a number of issues bound and limit the options for performing the pretreatment facility design testing. This section discusses the issues and provides recommendations for remedial action.

The bounding issues that have been identified and considered in this investigation are as follows:

- Needed sample sizes, quantity, and timing

- Present sample retrieval size and quantity capability

- Expanded sampling capability within CY 1995

- Expanded sampling capability in 18 to 24 months

- Sample transportation cask availability

- Sample transhipment capability

- Safety documentation and environmental permitting

- Cell accessibility on the Hanford Site

- Review of candidate sites' Quality Assurance Program.

The following sections will discuss each of these issues and as appropriate, provide recommendations for followup.

\subsection{NEEDED SAMPLE SIZES, QUANTITY, AND TIMING}

Figure 2-1 provides an approximation of the sample volume required each quarter of the next 3 years to support the pretreatment facility design testing using 200-mL ion-exchange columns for that test work. The data are derived from the catalog of issues (Appendix B-1) requiring hot testing, and test requirements (see Appendix B-2) which were based on PNL TWRSPP-94-096, Hanford Tank Waste Remediation Systems (TWRS) Waste Pretreatment Program Test Requirements Strategy and Issues (Reynolds 1994a). The data represent the approximate sample feed needed to respond to the IPM A-E's requested information avajlability dates as shown on the data sheets in Appendix B-1. The largest of these samples $(3,600 \mathrm{~L}$ per test) are to support ion-exchange testing of the crystalline silicotanates (CST) resin using $200-\mathrm{mL}$ column sizes and five repetitions with different wastes.

Figure 2-2 provides a similar presentation based on the same timing, but using 10- to 45-mL ion-exchange columns with the largest volume $(180 \mathrm{~L} /$ test and five test runs) also applied to testing the CST resin. Substantially larger quantities are needed for filter testing and centrifuge testing.

Because of the limited sample retrieval and handling infrastructure, neither of these schedules can be met except for tests requiring no more than a. few liters of sample material.

For comparison, Figures 2-3 and 2-4 provide the same data but on the probable basis that a $25-L$ retrieval capability will be unavailable until July 1996, and a 4,000-L capability will be unavailable until October 1996. It is also assumed that the earliest that samples $>100 \mathrm{~L}$ can be retrieved and handled is October 1996 using the 4,000-L transporter (Appendix C-4). As a result, white much cold-testing can be accomplished on all technologies, and 
WHC-SD-WM-TA-160

Revision 0

Figure 2-1. Pretreatment Testing Waste Sample

Requirements--Ion-Exchange Case 2.

Waste sample delivery volumes needed for tests to meet Architect-Engineer data dates. Basis: All tests with ion-exchange Case 2 at 200-mL columns.
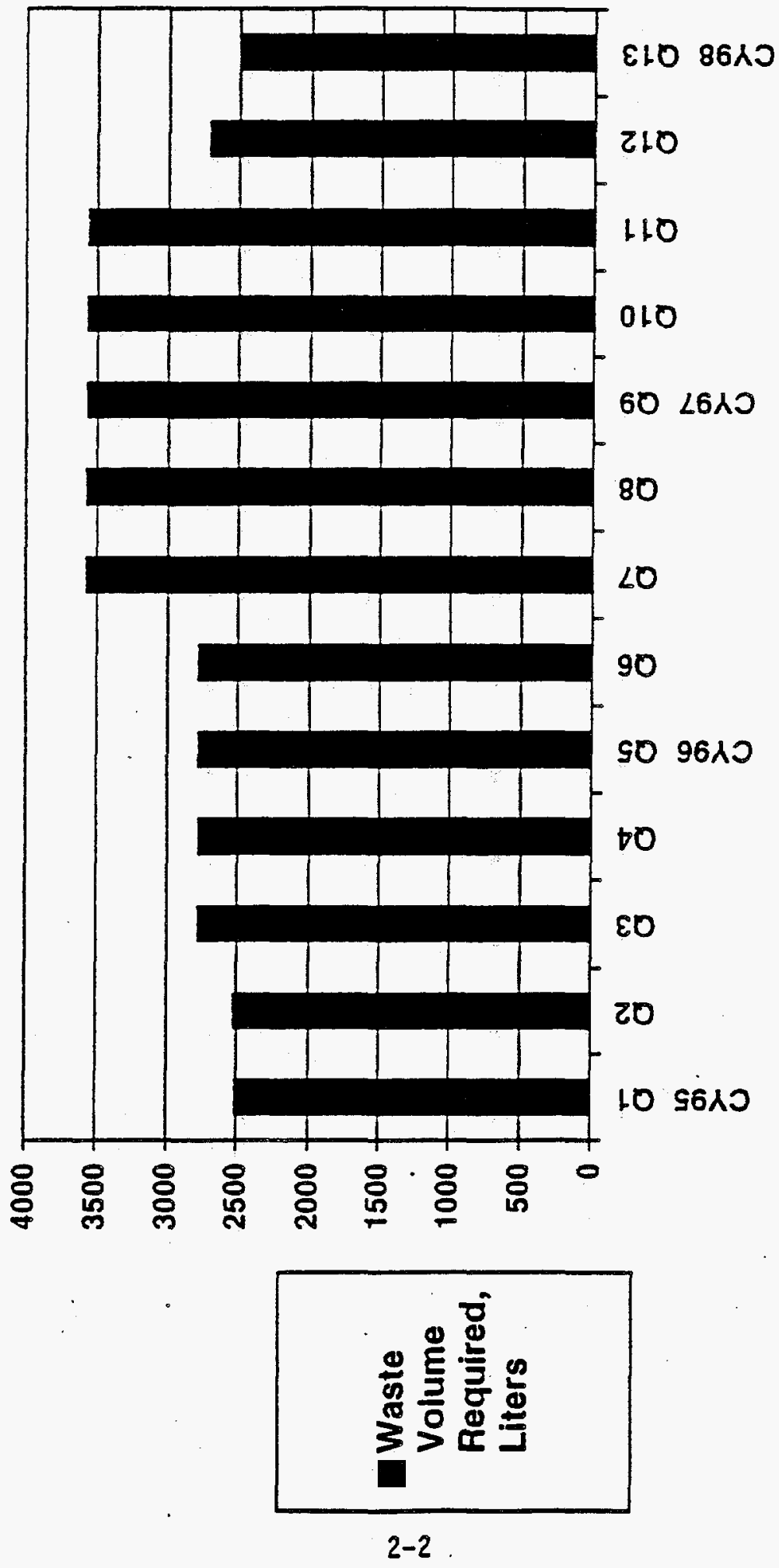


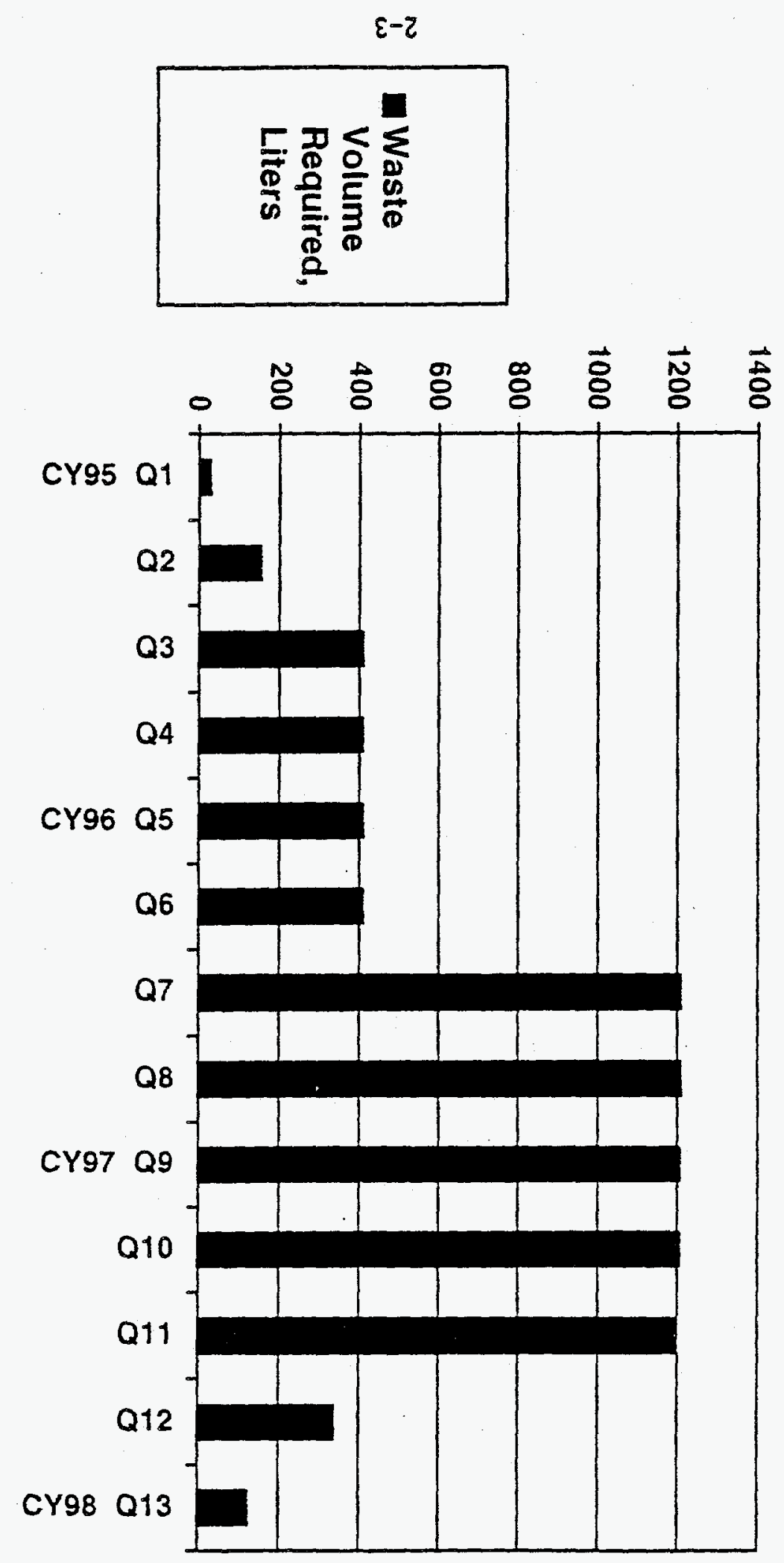

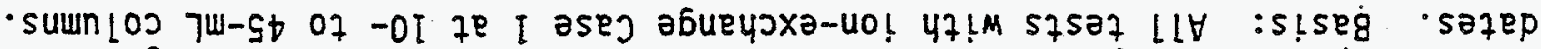

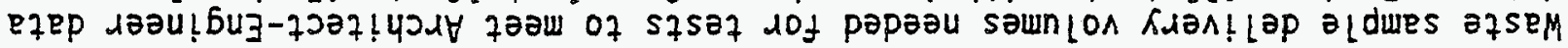

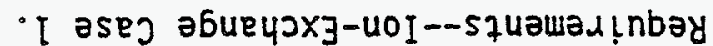

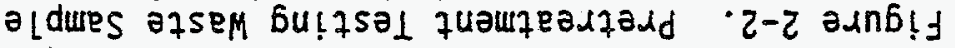




\section{WHC-SD-WM-TA-160 \\ Revision 0}

Figure 2-3. Pretreatment Testing Waste Sample Requirements--Ion-Exchange Case $2 \mathrm{~A}$.

Waste sample delivery volumes needed for tests to meet Architect-Engineer data dates. Basis: Ion-exchange Case 2. Tests requiring $>100 \mathrm{~L}$ deferred unti? October 1996.
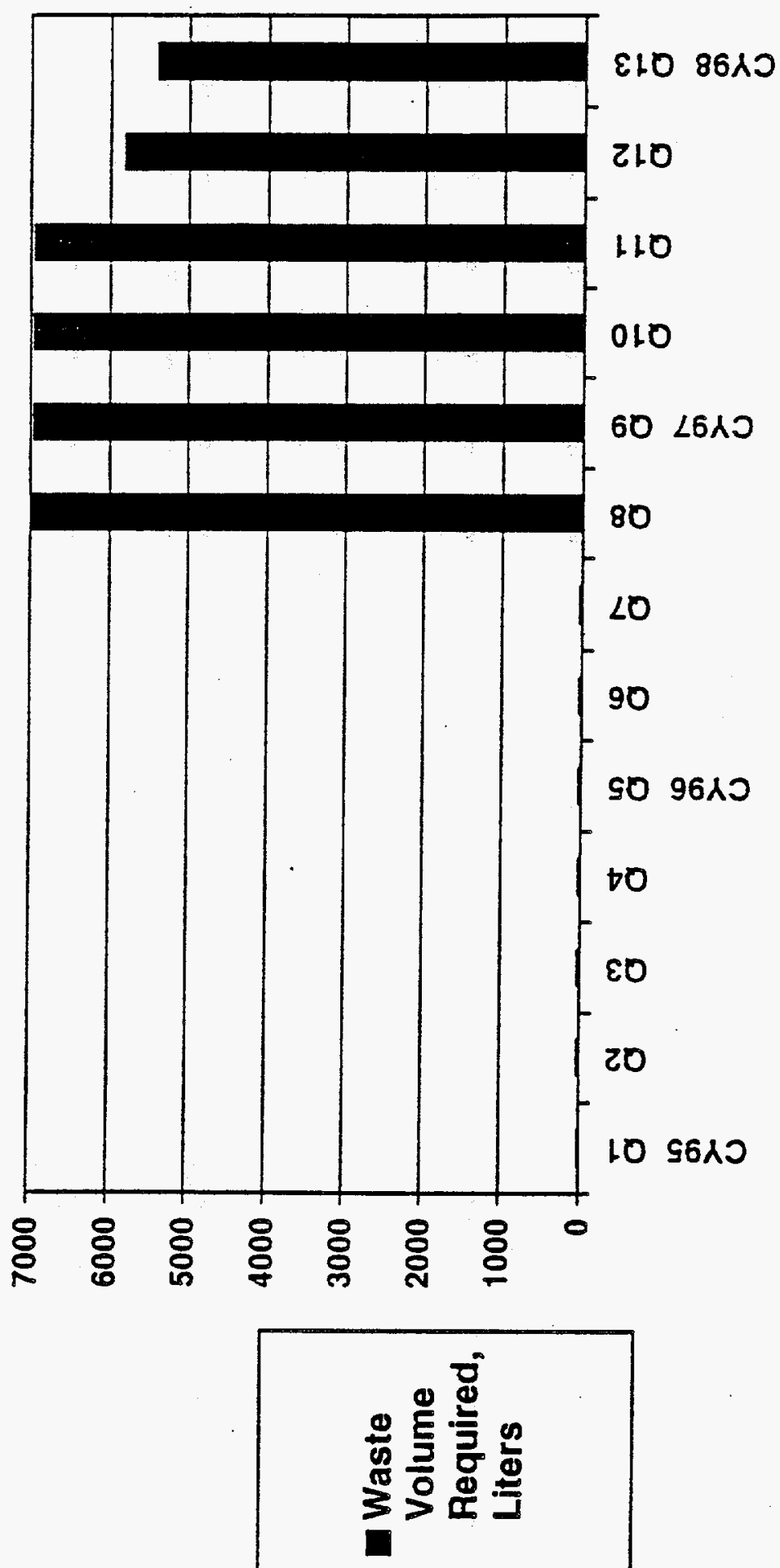
Figure 2-4. Pretreatment Testing Waste Sample Requirements--Ion-Exchange Case $1 \mathrm{~A}$.

Basis: Ion-exchange Case 1 . Tests requiring $>100 \mathrm{~L}$ deferred untit October 1996.
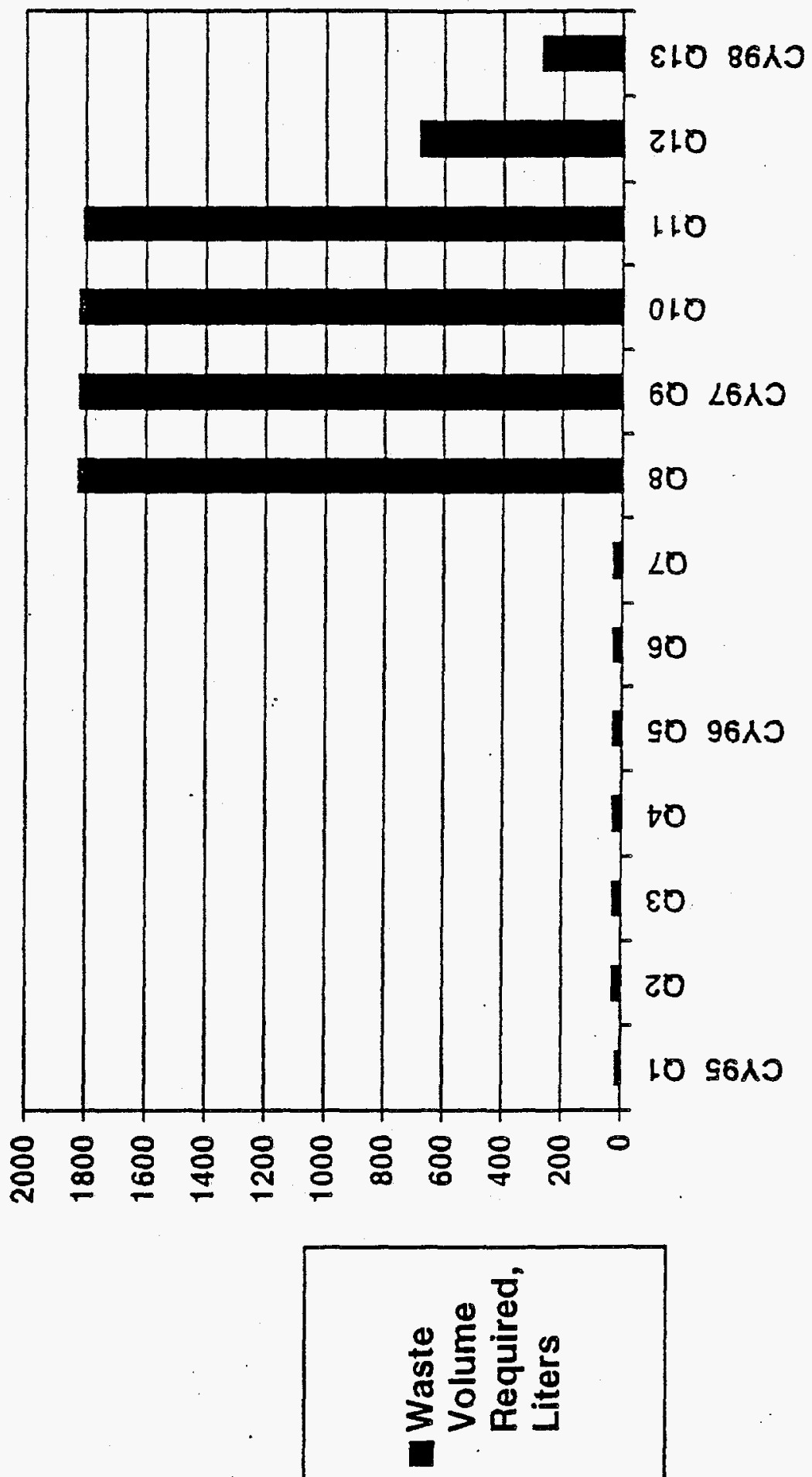
WHC-SD-WM-TA-160

Revision 0

some limited hot testing on some technologies during the next 18 to 21 months, most centrifugation, filtration, and ion-exchange hot testing will be delayed pending the availability of a 4,000-L transport capability starting around october 1996. However, its transporter procurement is in progress with delivery scheduled for December 1995. An October 1996 operational date is considered an achievable time frame for the supporting infrastructure (design and construction of load/unload capability, preparation of safety and environmental documentation, operating procedures and staff training) if started by early March 1995 :

An uncertainty that must be resolved while preparing the test plans is whether the test durations (estimated at about 200 days for five runs) and the delayed start date (October 1996) may force the use of parallel ion-exchange test lines, each using different resins.

\subsection{RRESENT SAMPLE RETRIEYAL SIZE AND QUANTITY CAPABILITY}

As discussed in Section 1.4, the present tank waste sampling capability is limited to $100-\mathrm{mL}$ grab samples and up to $250-\mathrm{mL}$ sludge and solids samples. Table 2-1 shows the current plan for retrieving larger samples to support pretreatment testing for FYs 1995 and 1996, and early FY 1997 using extraordinary effort and the existing sampling equipment. While this effort and the volumes retrieved are important to enable smaller scale hot testing to proceed, they are not adequate for projected needs discussed in Section 2.1. To enable test work to proceed, development of a spectrum of sampling tools and supporting systems is recommended. Presented below is a strategy for development that will support small-scale testing during CY 1995 and increasingly larger scale testing as progressively larger sampling capabilities become operational throughout $C Y$ 1996. In the long run, it will provide a selection of sampling capability to support a wide range of testing for the pretreatment mission and subsequent vitrification programs.

\subsection{EXPANDED SAMPLING CAPABILITY WITHIN CY 1995}

A 500-mL sampler is commercially available at a cost that may preclude reuse, i.e., it is more cost-effective to discard rather than clean and reuse. This unit will have applications beyond $C Y$ 1995, but its graatest benefit will be to help meet the retrieval schedule shown in Table 2-1. Pigs or casks will be a critical path issue for this capability.

Savannah River Plant (SRP) staff have fabricated a $3-L$ version of their 25- 1 sampler device (see photographs and figures in Appendix $C-1$ ). The mechanism and its operation are similar with the advantage that they are smaller in diameter and length. The radioactivity dose rate would be somewhat less than that emanating from a $25-L$ sampler; however, extensive shielding would stili be required. The weight of this sampler/container is within the capacity of hoisting systems available within the 222-5 Laboratory for handling and sample recovery. With aggressive effort, this unit could be operational by the end of CY 1995 or eariy CY 1996 using a boom crane to lower it into a tank riser until a more dedicated truck-mounted system (Appendix $\mathrm{C}-2$ ) is developed. The $3-1$ sampler would enable efficient recovery of all five of the 2- to $4-L$ samples for settle/decant testing, samples in 
Table 2-1. Fiscal Year 1995 Planned Large-Volume Sample Retrieval Schedule - November 30, 1994.

\begin{tabular}{|c|c|c|c|c|}
\hline Tank & $\begin{array}{c}\text { Additional } \\
\text { volume }\end{array}$ & Material & Method & Scheduled start \\
\hline C-107 & $1 \mathrm{~L}:$ & Sludge/saltcake & Push & January 1995 \\
\hline BY-109 & 1 core & Sludge/saltcake & Rotary & March 1995 \\
\hline AW-101 & $3 \mathrm{~L}$ & Supernate & Push & April 1995 \\
\hline AN-107 & $200 \mathrm{~mL}$ & Sludge/saltcake & Grab & May 1995 \\
\hline AN-107 & $5.1 \mathrm{~L}$ & Supernate & Grab & May 1995 \\
\hline C-106 & $600 \mathrm{~mL}$ & Sludge/saltcake & Rotary & June 1995 \\
\hline AP-105 & $6.1 \mathrm{~L}$ & Supernate & Grab & August 1995 \\
\hline AN-102 & $15 \mathrm{~L}$ & Supernate & Grab & September 1995 \\
\hline AN-105 & $5 \mathrm{~L}$ & Supernate & Push. & November 1995 \\
\hline S-107 & $1,000 \mathrm{~mL}$ & Sludge/saitcake & Push & February 1996 \\
\hline BX-109 & $200 \mathrm{~mL}$ & Sludge/saltcake & Push & February 1996 \\
\hline TX-105 & 1 core & Saltcake & Rotary & April 1996 \\
\hline AW-105 & $850 \mathrm{~mL}$ & Supernate & Push & June 1996 \\
\hline B-109 & $400 \mathrm{~mL}$ & Sludge/saitcake & Push & September 1996 \\
\hline A-103 & $1,000 \mathrm{~mL}$ & Sludge/saltcake & Push & January 1997 \\
\hline
\end{tabular}

Source: G. D. Forehand message to G. F. Howden, November 30, 1994, Westinghouse Hanford Company, Richland, Washington.

the 2- to 10-L range for all three organic defunctionalization tests, and one 15- $L$ ion-exchange test sample, recovered resulting in acceleration of those schedules by at least 6 months, compared with waiting for the 25-L sampler capability discussed in Section 2.4.

\subsection{EXPANDED SAMPLING CAPABILITY - 18-MONTH SCHEDULE}

The capability to retrieve 25-L samples using the SRP sampler concept (Appendixes $\mathrm{C}-1$ and $\mathrm{C}-2$ ) could be available within 18 months. This effort will be more extensive because new transfer casks and intermediate containers will have to be designed and qualified, a portable tank riser interface device designed and fabricated, a sampler receiving and service cell set up, permits and procedures prepared, and operating staff trained. A working model of the SRP 25-L sampler is onsite and the WHC Transportation \& Packaging engineering staff have prepared packaging design criteria for the sampler's transfer cask and container. 
WHC-SD-WM-TA-160

Revision 0

The 25-L sampler capability would enable efficient recovery of ten $25-L$ samples and one (early) 100-L sample for filtration testing, an early $100-L$ sample for centrifugation, and nine 15-L samples for more advanced ionexchange testing.

The above sample data for the $500-\mathrm{mL}$ through the $25-\mathrm{L}$ sampler should be considered as minimum quantities because testing often identifies other issues with testing requirements.

The sample data in Appendix B-2 indicate an estimated 14 to 20 samples with volumes ranging from 100 to $3,600 \mathrm{~L}$. Those volumes cannot reasonably be taken on a steady basis by any of the previously discussed sampling equipment. The WHC Tank Farms Maintenance organization has purchased a French-built LR-56 high-activity, over-the-road transporter with a capacity of 4,000 L. Figures and data on this system can be found in Appendix $\mathrm{C}-3$. The transporter is scheduled for delivery in December 1995. The LR-56 is for onsite use, including the 300 Area. (This transporter was considered for shipping large samples to other DOE sites for testing, but WHC Transportation \& Packaging engineering staff have indicated that an environmental impact statement would have to be prepared for use of the transporter off the Hanford Site. The time required for that activity is beyond the time window of the test work. Also, as discussed in Section 2.5, indications are that some states would oppose the use of the transporter on their highways.)

With authorization by early March 1995, design and construction of a relocatable load and unload capability for use at the several tank farms and fixed receiving facilities in the 324 and 325 Buildings could be completed to start beneficial use of the system for hauling samples by october 1996 . The acceptability of the concept of a routinely used transportable load/unload capability for use at the tank farms hinges on the successful resolution of safety and containment issues that may arise during the design phase.

Because the unit has been purchased to make emergency transfers from a leaking tank, it will only be available on a fast turnaround bas is and cannot be used as a storage or processing vessel at a test site. Cost of the transporter is about $\$ 2$ million. Further assessment of peak demand for samples may dictate procurement of a second unit that would also provide a backup for tank farms emergency situations and a capability for removing existing high-activity waste from tanks in Buildings 324 and 325.

\subsection{SAMPLE TRANSPORTATION CASK AVAILABILITY}

Several types of shipping containers are, or soon will be, available and qualified for offsite shipment of small samples of tank wastes. These casks are shown in Table 2-2.

The WHC Packaging Engineering staff have been working to obtain DOE approval to permit the PAS-1 (Appendix C-4) cask to carry up to $4 \mathrm{~L}$ of liquid radioactive material on public roadways. Approval of the cask Certificate of Compliance is expected by early $\mathrm{CY}$ 1995. The PAS-1 Certificate of Compliance would allow the transportation of $4 \mathrm{~L}$ of liquid radjoactive material per cask for a total of $16 \mathrm{~L}$ per month during at least part of $C Y 1995$. Packaging Engineering staff have indicated that the PAS-1 may be readily modified 
WHC-SD-WM-TA-160

Revision 0

Table 2-2. Cask Descriptions.

\begin{tabular}{|l|c|c|c|}
\hline \multicolumn{1}{|c|}{ Name } & Type & Capacity & Quantity/avai]ability \\
\hline $\begin{array}{l}\text { WHC Tiquid sample } \\
\text { package* }\end{array}$ & A & $4 \mathrm{~L}$ & $6+$ \\
\hline Warthog & A & $250 \mathrm{~mL}$ & $1-10$ by May 1995 \\
\hline Hedgehog & A & $400 \mathrm{~mL}$ & $1+$, certified by March 1995 \\
\hline PAS-1 & B & $4 \mathrm{~L}$ & 2, certified by March 1995 \\
\hline
\end{tabular}

*This package is unshielded.

WHC = Westinghouse Hanford Company

internally to carry up to $8 \mathrm{~L}$ /cask, provided hydrogen generation limits are not exceeded during the transportation time. An added permitting effort would be required to increase the capacity and would take an estimated 8 to

12 months to accomplish. Offsite shipment capacity during CY 1995 will therefore be limited to about $16 \mathrm{~L}$ per month, possibly doubling by mid-CY 1996.

The transportation of tank wastes was determined to be the limiting factor for performing larger scale $(>30$ to $50 \mathrm{~L}$ ) testing off the Hanford Site. Two interstate highway routes are available for moving tank waste samples from the Hanford Site to other sites. The closest route to the Idaho National Engineering Laboratory (INEL), Los Al amos National Laboratory (LANL), and Oak Ridge National Laboratory (ORNL) would be via Interstate 80 through Oregon. Oregon State Department of Transportation (OSDT) representatives have indicated in recent meetings that the OSDT would support the shipment of up to four PAS-1 cask shipments per month of tank waste samples to the other northwest states (Stroup 1994); however, the OSDT representatives have indicated that they probably would not support the shipment of larger waste samples. As a result, this analysis is based on a maximum shipment of 30 to 50 L of waste to a site (approximately 1 I/2 months' shipping capacity) for a specific group of tests.

This limit per group of tests would allow up to eight other similar-sized samples to be shipped each year to one or more DOE sites. All sites except ORNL have indicated that they would have to return the waste to the Hanford Site after completing any test work. Return of sample remains and secondary test wastes would not decrease the number samples that could be shipped from the Hanford Site.

Some added cask capability for handling smaller volume samplers would be required for onsite use, as shown in Table 2-3.

Providing casks to meet the need dates for the $500-\mathrm{mL}$ and $3-\mathrm{L}$ samplers is expected to require an aggressive effort. The time available to provide the 25-L sampler and 25-L sample casks is achievable on a more normal basis. Immediate action to design and procure these casks is recommended. 
WHC-SD-WM-TA-160

Revision 0

Table 2-3. Cask Capabilities for use at the Hanford Site.

\begin{tabular}{|c|c|c|}
\hline Description/application & $\begin{array}{c}\text { Quantity } \\
\text { (minimum) }\end{array}$ & Need date \\
\hline $500-m L$ sampler cask & 4 to 6 & May 1995 \\
\hline $3-L$ sampler cask & 4 to 6 & November 1995 \\
\hline $25-L$ sampler cask & 6 & May 1996 \\
\hline $25-L$ sample cask & 3 & July 1996 \\
\hline
\end{tabular}

\subsection{SAMPLE TRANSHIPMENT CAPABILITY}

A survey of the requirements and capability for receiving and handing the 500-mL, 3-L, and 25-L samplers indicated that the 222-S Laboratory staff would have the capability and interest in supporting the $500-\mathrm{mL}$ and $3-\mathrm{L}$

sampler servicing and sample transhipment mission. The facility does not have the structural features or crane capacity to enable its use to service the 25-L sampler. A new location will be required for that unit.

An initial scoping of the requirements for a window-type cell to receive and handle the 25- $L$ sampler, its maintenance, and the repackaging of the sample is as follows:

- About 5.6 to $6.5 \mathrm{~m}^{2}$ of floor space

- A means of top entry into the cell for the sampler

- An incell crane with a 0.45 -metric ton minimum capacity

- A crane above the cell capable of handling a 9-metric ton cask.

It is recommended that the 222- 5 facility be designated as the transhipment point for the $500-\mathrm{mL}$ and $3-\mathrm{L}$ samplers. The Waste Encapsulation and Storage Facility (WESF), 324 radiochemical engineering (RCE) Cell $C$, and $325 \mathrm{~A} C$ Cell $B$ or $C$ have the above-listed attributes that would enable their use for the 25-L transhipment function. The 324 RCE Cell $C$ is recommended by the hot testing site evaluation team for the mission based on its immediate availability, capability to meet the functional requirements, and low cost for access. The cell will need to be dedicated to this mission for 3 to 4 years.

Each facility that will receive samples via the LR-56 transporter will require a shielded interface capability, including enclosure for the vehicle during unload/reload activity and shielded/encased pipelines from the vehicle interface to receiving and effluent discharge tanks. Those facilities requiring this capability will be identified and discussed in Sections 4.0 and 5.0.

Preliminary discussions have been held with the Waste Tank Plant Engineering representative regarding design of a load/unload capability at one or more of the tank farm sites. An engineering study is required and recommended to provide a safety analysis and the design functions and requirements of this capability within the next 2 months. 
WHC-SD-WM-TA-160

Revision 0

\subsection{SAFETY DOCUMENTATION AND ENVIRONMENTAL PERMITTING}

The following sections identify safety documentation and permitting requirements that may affect the time required to make a facility operational for testing. Bolded text indicates facjijty development project hold points that will have to be observed in schedule development.

\subsubsection{Safety Documentation}

The safety analysis documentation requirements for each candidate facility are based on the status of the current facility safety documentation and the potential hazard of the proposed activity.

The status of the facility safety documentation is assessed based on (1) conformance to current criteria established in DOE Orders 5480.23 (DOE 1992a) and 5481.1B (DOE 1986), and (2) the similarity of the proposed activity to the facility operations evaluated in the safety documentation. the safety documentation meets the current criteria and the evaluation of the facility operations encompasses the proposed activity, no new safety documentation would be required. This is the likely case for the performance of laboratory-scale testing. If the safety documentation is not current (e.g., WESF/B Plant), any upgrades required will depend on the similarity of the proposed activities with the current facility operation. If the hazards of the proposed activity are not bounded by the current facility operations, an additional accident analysis will be required. Approval of the safety documentation in this case will require that the documentation be upgraded to current safety analysis criteria.

The hazard of the activity is affected by the quantity of material at risk and the energy sources present in the process which could disperse the material.

Small quantities ( $<10 \mathrm{~L}$ ) of high-activity waste are not expected to exceed the Category 3 threshold specified in DOE-STD-1027-92 (DOE 1992b). The applicable safety documentation requirements are specified in DOE Order 5481.1B for facilities whose inventories do not exceed Category 3 limits. The safety documentation requirements for facilities whose inventories do exceed Category 3 limits are specified in DOE Order 5480.23. Large quantities $(>1,000 \mathrm{~L})$ of high-activity waste could exceed the Category 2 threshold specified in DOE-STD-1027-92. Facilities whose inventories exceed the Category 2 levels (e.g., ion-exchange Case 2 testing) are required to include a greater amount of detail on the potential accidents and their consequences.

Energy sources associated with the proposed activities are considered in determining the potential hazards associated with the facility. Energetic reactions (e.g., ion exchange), which could increase the dispersal of hazardous material, require a greater amount of analysis. 
WHC-SD-WM-TA-160

Revision 0

\subsubsection{National Environmental Policy Act of 1969 (NEPA) Documentation}

The NEPA documentation is required to be in place before (1) detailed design, (2) committing irretrievable funds, and (3) construction or equipment installation. The NEPA is regulated by the DOE.

The NEPA documentation will be required for any testing with actual tank waste. If the planned activities are not covered under existing NEPA documentation, additional NEPA documentation will be required. The specific NEPA documentation required cannot be determined until the actual location and extent of the testing activities are known. However, it appears a categorical exclusion (CX) would be required. A CX would be required if the waste is tested at the Hanford Site or shipped to another site. If the waste is shipped to another site, that site would require additional NEPA documentation to cover the activities conducted there (probabiy a CX). A CX will take approximately 3 months to prepare and approve. If a $C X$ is not sufficient and an environmental assessment is required, preparation and approval may take up to 12 months.

\subsubsection{Resource Conservation and Recovery Act of 1976 (RCRA) Permitting}

The RCRA permits would be required before any construction work related to the testing program is initiated and before equipment is installed in hot cells where construction is not required.

To meet RCRA regulations, the testing site will be required to obtain a research, development, and demonstration (RD\&D) permit or a treatability study (TS) exemption. A TS does not require a permit and can be obtained by obtaining permission to conduct the onsite tests from the Washington State Department of Ecology (Ecology) for the Hanford Site, or responsible state authority at other DOE sites. This can be done in 1 to 3 months. A TS exemption has waste quantity restrictions. The restrictions are a maximum of $1,000 \mathrm{~kg}$ of waste for each process being evaluated for each waste stream. It is uncertain whether Ecology will concur that wastes from separate tanks constitute different streams and whether a change in the process material (e.g., resin) constitutes a change in process. If the State did interpret all tank wastes as one waste stream, an RD\&D permit would be required. An additional $500 \mathrm{~kg}$ of waste can be used on a case-by-case basis if there (1) has been an equipment failure, (2) is a need to verify the results of a previous study, (3) is a need to study and analyze alternative techniques within a treatment process, or (4) is a need to further evaluate an ongoing TS to determine final specifications. If waste quantities $>1,500 \mathrm{~kg}$ per process per waste stream are needed, an RD\&D permit will be required.

The limitation on an RD\&D permit is the treatment of no more than $15,000 \mathrm{~kg}$ of waste per month. There is also a time limitation of 3 years, including permit renewa1s. An RD\&D permit would require approximately 12 months to obtain. The TS would be regulated by Ecology (in Washington State), while the RD\&D permit would be regulated by the U.S. Environmental Protection Agency (EPA). 
Similar requirements wit7 be required if the tests are conducted at other sites. All sites, regardless of location, would have to meet at a minimum the federal or state RCRA treatment and storage requirements.

\subsubsection{Air Permits}

The air permits would be required before construction or equipment installation.

Air permits required for the testing depend on the test location and the waste being tested. If the tests are conducted in a facility with existing air permits that cover the proposed activities, additional permitting may be unnecessary or the permits may only require amending. Depending on the waste, as many as four air permits could be required and, depending on the permit, would be regulated by the EPA, Ecology, or the State of Washington Department of Health. If the tests are conducted in an existing facility, air permits could probably be obtained within 9 months, while a new facility could require up to 17 months. Similar requirements would apply at other sites in other states.

It is recommended that a detailed assessment of the permitting status of those facilities/sites recommended in Sections 4.0 and 5.0 be initiated immediately to confirm status information received during this assessment study. Preparation of an RD\&D permit application must be initiated by April 1995 for the Case 2 ion-exchange test work because it will exceed the $1,500 \mathrm{~kg}$ per process limit as indicated in Appendix B-2.

\subsection{CELL ACCESSIBILITY ON THE HANFORD SITE}

The cells needed for this work are window-type cells outfitted with master/slave manipulators to support equipment installation, operation, analytical sample taking and handling, equipment troubleshooting, and in situ remedial action or repair.

Some cell space is available in the 222-S Laboratory with little cleanout required.

Cell space may be available in the WESF, but by the time permits are obtained to initiate cleanout and staffing is made avajlable, it will be early to mid-CY 1996 before the cells can be accessed for equipment installation for any application. That time delay is prohibitive.

Eighteen new cells in sizes ranging from 3.4 to $372 \mathrm{~m}^{2}$ are available in the FMEF in the 400 Area. Many of the smaller cells are stainless steel lined and have shielding windows, manipulators, and other equipment to outfit them available for installation. Some construction work would be required to complete. the cell ventilation systems and provide piping and tankage to interface with the LR-56 transporter and the cells. Because of the time required to design and permit needed work described, it would take 12 to 18 months to make the cells available for equipment installation, assuming the work was done using expense funding. Capital funding would add an additional year or more to the schedule. That time delay is also prohibitive. 
WHC-SD-HM-TA-160

Revision 0

Cells $C$ and $D$ in the 324 Building's RCE cell complex are available immediately. Cells in the Shielded Materials Facility (SMF) complex are available immediately, but require minor cleanout (East Cell) to major cleanout (South Cell) and modification to make them better suited for remote maintenance. The cells can now be entered for maintenance, cleanout, and. interior modification after removal of the source term. Some construction will be required to provide high-activity radioactive waste drains from the SMF cell complex and to provide large-volume sample transfer lines to the RCE and SMF cells for transferring waste from/to the LR-56 transporter.

In Buildings $325 \mathrm{~A}$ and $\mathrm{B}$, four cells are also available that have been or are now nearly cleaned and ready for a new mission. Some of these cells are available immediately for a new mission. They will require installation of some shielded piping between the truck dock and cells for transferring large samples from the LR-56 transporter.

Recommendations on use of these cells are provided in Sections 4.0 and 5.0 .

\subsection{OTHER SITING CONSIDERATIONS}

Early in the site evaluation, the issue of comparatively ranking the attributes of a compact processing unit (CPU) for doing hot testing with those of window-type hot cells was discussed by the evaluation team. Based on current knowiedge of the facility functional needs for doing hot testing, the tight schedule for performing the test work, and the significantly higher cost of designing and building a CPU-housed process, the evaluation team decided that the most flexible and less costly testing option is to use existing window-type hot cells to the extent they are available. The findings to date are that there are enough window-type hot cells available to exceed the current need. The development of a 4,000-L aboveground sample transport system that is now in progress at the Hanford Site supports this decision by providing the capability for high flow rate testing (should it be required), in fixed window-type cells. The 4,000-L transporter also provides access to a larger range of tank wastes than would be possible with a CPU located at a tank farm.

The use of the Plutonium Uranium Extraction (PUREX) and B Plant canyon or canyon cells was considered but discarded early in the assessment. The basis for this judgement was as follows:

- Staffed access to the canyons is very difficult and is minimized for personnel safety (as low as reasonably achievable). Setting up a shielded enclosure at canyon floor level for containment and operation of a test would be difficult to access, and would have to essentially operate in a full remote, non-contact mode of operation and maintenance. Sample taking could be manually accomplished but with higher staff exposure for canyon entry.

- All pipelines between the tank farms and PUREX or B Plant are single wa11 concrete-encased lines that do not meet current double containment requirements. They are operated on a limited basis for waste transport from the plants. When they were operated for tank 
waste transfers, their operation generated about 80,000 to $160,000 \mathrm{~L}$ of 7 ine preheat and flush water per transfer. A minimum pipeline transfer was considered to be about $40,000 \mathrm{~L}$ of waste.

- Use of the canyon cells or a new canyon floor level cell would require new and difficult to install doubly contained piping to/from the cell to a point a truck type transporter could access, and double containment for the test apparatus. It would also require nearly full remote, non-contact operation and maintenance. Use of below floor-level cells would require semi-remote sample recovery. All of these canyon set-ups would be more expensive and time consuming to establish than a window cell test set-up.

The use of the PUREX or B Plant canyons or canyon cells was therefore not considered practical for the scale of testing that has been identified.

\subsection{QUALITY ASSURANCE PROGRAM REVIEW}

The Quality Assurance Program Plan of each of the candidate sites was reviewed to ensure that data provided by their testing work would meet the IPM Project's minimum needs. The program attributes described in these plans were compared to the programmatic requirements described in 10 CFR 830 , "Nuclear Safety Management," Subpart A, "General Provisions," Section 830.120, "Quality Assurance Requirements." The review team concluded that the programs of the candidate sites meet the minimum programmatic requirements necessary to support the IPM Project design with qualified test data. Some coordination will be required with supporting sites to ensure uniform application. 
WHC-SD-WM-TA-160

Revision 0

This page intentionaliy left blank. 
WHC-SD-WM-TA-160

Revision 0

\subsection{SITE EVALUATION METHODOLOGY SUMMARY.}

Preliminary test facility functions and requirements for the hot testing process have been prepared to support the IPM Project design test work (Reynolds 1994b). The functions and requirements were organized into six categories of technologies: ion exchange, sludge washing, organic defunctionalization, settling/decanting, filtration, and centrifugation. This method was chosen to reduce the number of alternatives to be evaluated and make the evaluation problem more manageable.

The functions and requirements document was summarized into Assessment Matrices in (Reynolds 1994c). This report contained six detailed spreadsheets for the six technologies. In reviewing the spreadsheets, the evaluation team decided that nearly all sites and window-type cell facilities have common attributes that would score essentially the same in the evaluation. By eliminating those evaluation attributes from the spreadsheets, the spreadsheets were reduced to one common set of two pages and 12 criteria. These spreadsheets provided the basis for evaluating candidate sites and facilities.

Before initiating the site visits and evaluations, an initial four-stage screening of the candidate sites was implemented to focus the site visits and evaluations on those with the highest potential for support of the test program. The screening steps were as follows.

1. Working with the WHC analytical staff, an initial matrix of known site capabilities of the several DOE sites was prepared to identify those most likely to have the needed capability.

2. Personal contacts were made with key operations or program management staff (see Preliminary Hot Test Siting Evaluation, Appendix D-1) at the selected sites to solicit a preliminary indication of interest and an initial site survey was sent for review and response by return mait. A copy of the site survey format and spreadsheet of survey responses is included in Appendix D-1.

3. Following site visits to ORNL, LANL, INEL (ANL-W and Lockheed Idaho Technology Company [LITCO]) and hot cell facilities on the Hanford Site, and using a detailed data package from ANL-E, data sheets on key attributes of each site/facility were prepared (Appendix D). Also prepared were spreadsheets that show the logical groupings of several issues and the major test support requirements of each grouping (Appendix B-2). The test information need dates shown on these spreadsheets were provided by the IPM Project A-E in JuTy 1994 and were based on the schedule and Multi-Year Program Plan for the project (see the spreadsheets in Appendix B-2).

4. Using the site attribute data sheets (Appendix D-2) and the test grouping spreadsheets (Appendix B-2), a preliminary assessment of the candidate sites was made to el iminate those candidates that could not be provided with suitably sized waste samples (due to retrieval or transportation issues) or that did not meet minimum 
WHC-SD-WM-TA-160

Revision 0

cell requirements. The assessment sheets on the Hanford Site's 222-S Laboratory facility are included in Appendix $\mathrm{D}-3$ as an example.

The grouping of issues referred to in " 3 " above and shown on the tabies in Appendix B-2 were developed by the evaluation team using the following "rules."

1. Work on an issue (see Appendix B-1 for list of issues) will not be split between sites; that is, when an issue requires combination of cold and hot testing, the work will a 11 be done at the same site. The basis for this rule is avoidance of data correlation problems, reduced coordination, and administration costs.

2. Issues that can use the same radioactive sample(s) for resolution will be combined/grouped and will not be split between sites. The basis for this rule is avoidance of unnecessary retrieval and shipping of radioactive waste samples.

3. Issues that require an elaborate/costly hot laboratory or hot cell setup and can be resolved on the same setup as another issue(s) will be combined/grouped. The basis for this rule is avoidance of unnecessary test apparatus setup cost. The guidance for this rule is costs over $\$ 25,000$ per setup.

Those candidate sites successfuliy meeting this screening for each technology were analyzed to provide data for use by Pacific Northwest Laboratory's (PNL) Decision Analysis group to rank the hot cells at the several sites for suitability for each test group. Appendix $E$ provides summary spreadsheets of the evaluation scoring of all the candidate facilities and cells. 


\subsection{CONCLUSIONS AND DISCUSSION}

This section will present and discuss the computer decision analysis program ranking of the candidate hot testing sites and their hot cells. This section will also present the results of the site evaluation team's application of the site/facility ranking data. A brief description of each candidate hot cell facility and figures showing the facility arrangement are provided in Appendix.D-2.

\subsection{SITE/FACILITY RANKING METHODOLOGY}

The methodology of the series of supporting studies and site screenings was summarized in Section 3.0. On completion of the site evaluation data sheets described in Section 3.0 , those data were analyzed using a computer program applying the Multiattribute UtiTity theory (Clemen 1991; Keeney 1992). A detailed description of the ranking process is provided in Appendix $F$. The development of the measures and their scales was completed as part of the pre-site visit work. Following the site visits, the evaluation team met to develop the weights applied to the measures. Figures E-1 through E-14 in Appendix E display the scale values assigned to each measure by the two-person site/facility evaluation teams. Figures $E-1$ and $E-2$ also display the weights assigned to each measure by consensus of the fult site evaluation team.

\subsection{FACILITY RANKINGS}

Table 4-1 presents a tabulation of the weighted scoring of facilities evaluated under each technology testing group. A score of 100 would be the maximum score possible. Note that no scoring of offsite facilities was recorded for ion-exchange, filtration, and centrifugation testing. The reason was that anticipated waste shipping limits by adjacent states (Stroup 1994) would prohibit transportation of sufficient volumes of Hanford Site tank wastes to those sites to perform the tests.

The weighted scores of each facility shown on Table 4-1 were analyzed using the computer program to provide an overall ranking of all facilities for each technology.

The results of this ranking are shown on Figures 4-1 through 4-12 where the facilities are ladder ranked with the highest scoring facility/cell at the top.

\subsection{TEST GROUP SITING RECOMMENDATIONS}

The test siting evaluation team met to review the data provided in Figures 4-1 through 4-12 and to develop the recommendations for siting the specific test groups. The team decided that the facilities should be assigned based on their ranking relative to others in their test group, and based on a ladder ranking of the test groups that placed those requiring the largest tank waste samples at the top and the least at the bottom. The logic behind this decision was that those test groups that required the largest setups were the 


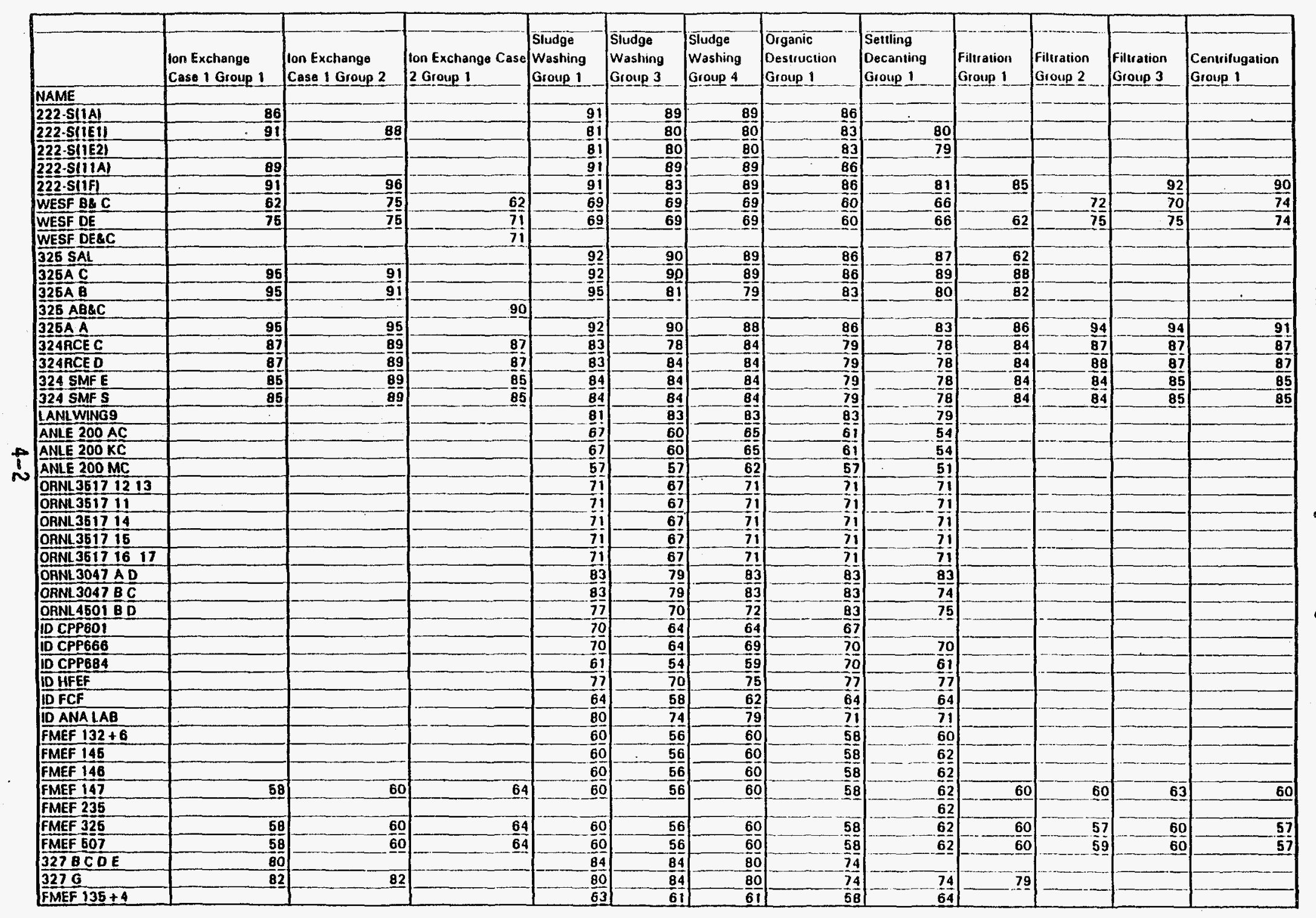


WHC-SD-WM-TA-160

Revision 0

Figure 4-1. Ranking of Hot Cells for Ion-Exchange 1-1.

Alternative Value

$325 \mathrm{~A} \mathrm{~A}$

95.22

$325 \mathrm{~A} \mathrm{~B}$

95.22

$325 \mathrm{~A} \mathrm{C}$

222-S(1F)

95.22

222-S(1E1)

90.93

90.89

222-S(11A)

88.56

324RCE D

87.35

324RCE C

87.35

222-S(1A)

86.48

324 SMF S

84.8

324 SMF E

84.8

$327 \mathrm{G}$

82.36

327 B C D E

80.09

WESF DE

WESF $\mathrm{B}+\mathrm{C}$

FMEF 507

75.17

75.17

57.67

FMEF 325

57.67

FMEF 147

57.67

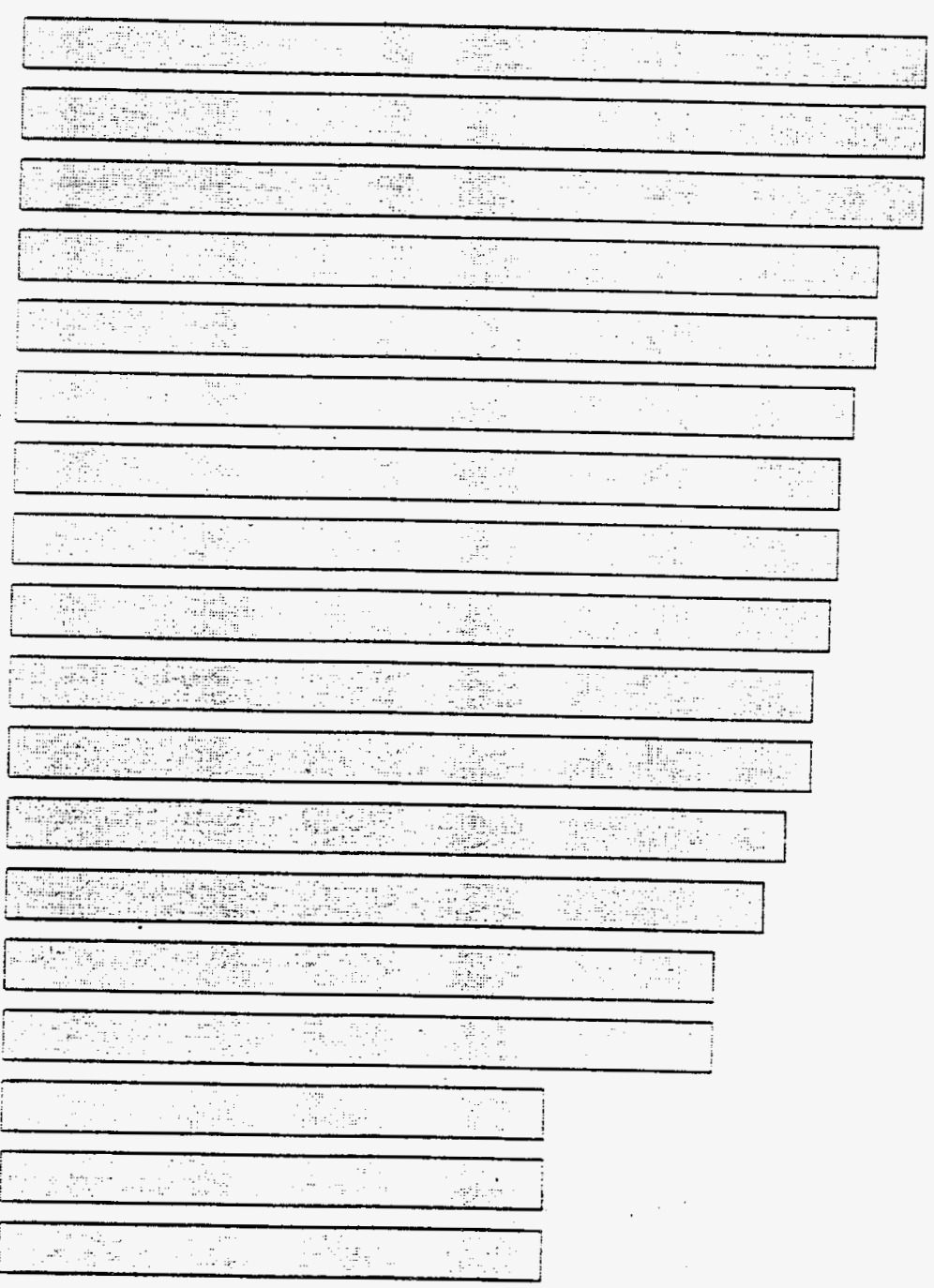


WHC-SD-WM-TA-160

Revision 0

Figure 4-2. Ranking of Hot Cells for Ion-Exchange 1-2.

$\begin{array}{ll}\text { Alternative } & \text { Value } \\ \text { 222-S }(1 F) & 95.7 \\ \text { 325A A } & 95.22 \\ \text { 325A B } & 91.48 \\ \text { 325A C } & 91.48 \\ \text { 324 SMF S } & 88.95 \\ \text { 324 SMF E } & 88.95 \\ \text { 324 RCE D } & 88.95 \\ \text { 324 RCE C } & 88.95 \\ \text { 222-S(1E1) } & 88.23 \\ \text { 327 G } & 82.36 \\ \text { WESF DE } & 75.17 \\ \text { WESF B }+C & 75.17 \\ \text { FMEF 507 } & 60.23 \\ \text { FMEF 325 } & 60.23 \\ \text { FMEF 147 } & 60.23\end{array}$

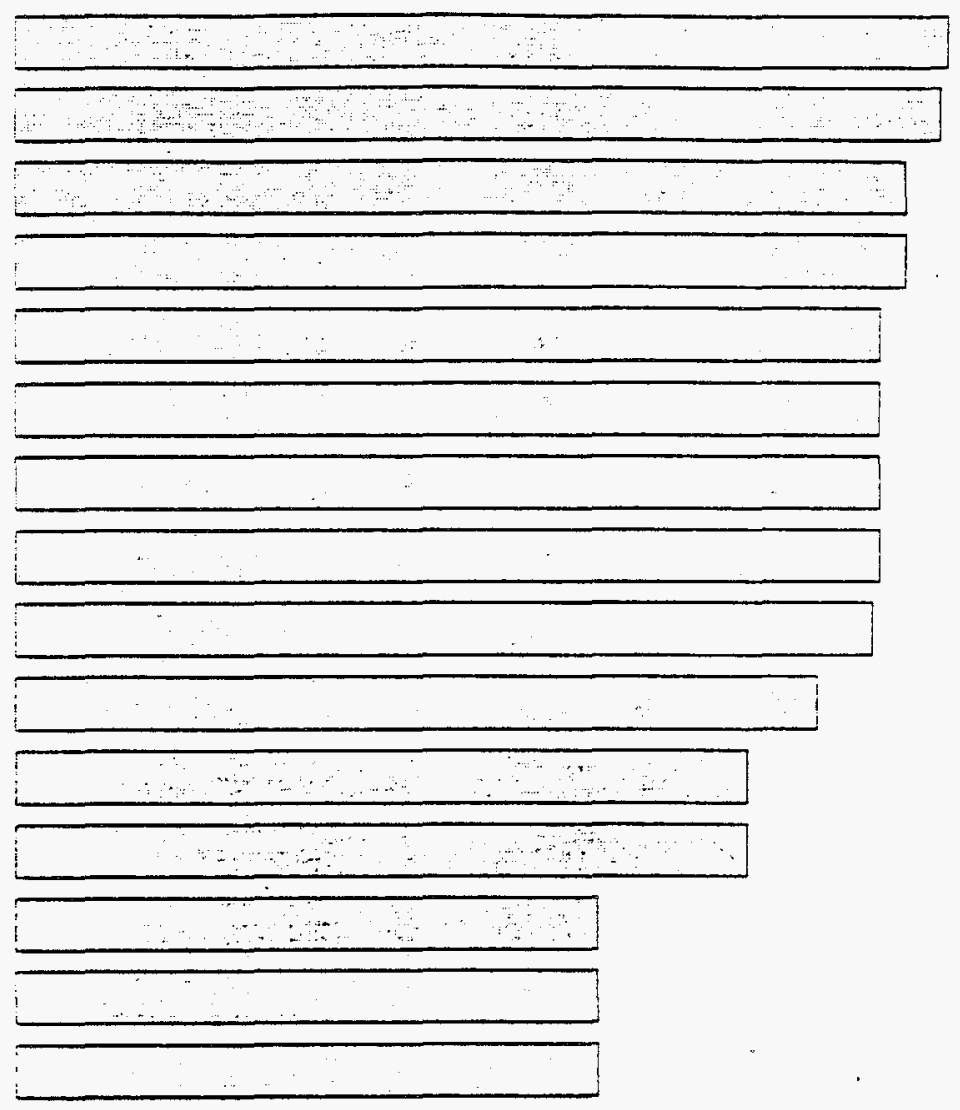


WHC-SD-WM-TA-160

Revision 0

Figure 4-3. Ranking of Hot Cells for Ion-Exchange 2-1.

$\begin{array}{ll}\text { Alternative } & \text { Value } \\ \text { 325 A+B+C } & 90.06 \\ \text { 324 RCE D } & 87.35 \\ \text { 324 RCE C } & 87.35 \\ \text { 324 SMF S } & 84.8 \\ \text { 324 SMF E } & 84.8 \\ \text { WESF DE+C } & 71.49 \\ \text { FMEF 507 } & 63.53 \\ \text { FMEF 325 } & 63.53 \\ \text { FMEF 147 } & 63.53\end{array}$

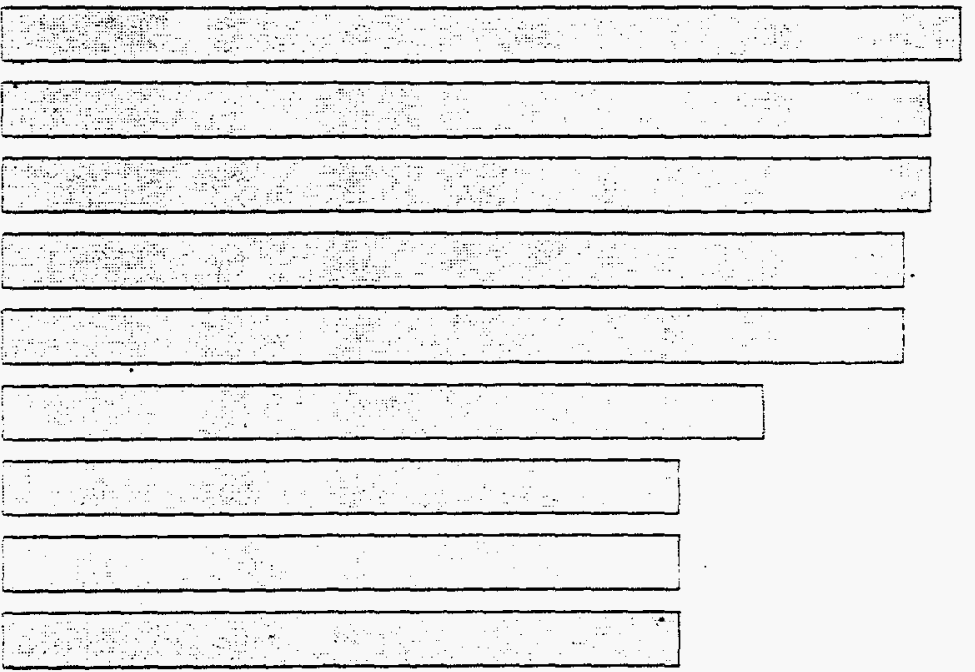


WHC-SD-WM-TA-160

Revision 0

Figure 4-4. Ranking of Hot Cells for Sludge Wash Group 1.

\begin{tabular}{|c|c|c|}
\hline Alternative & Vaiue & \\
\hline $325 \mathrm{~A} \mathrm{~B}$ & 95.22 & 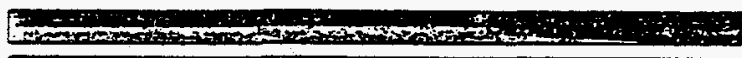 \\
\hline $325 \mathrm{~A} \mathrm{~A}$ & 92.04 & 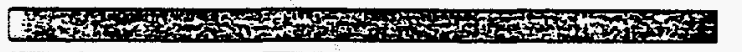 \\
\hline $325 \mathrm{AC}$ & 92.04 & 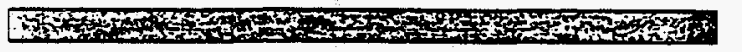 \\
\hline $325 \mathrm{SAL}$ & 92.04 & 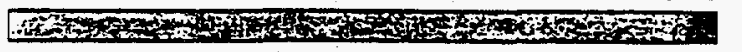 \\
\hline $222-S(1 F)$ & 90.93 & 4 (4) \\
\hline $222-S(11 A)$ & 90.93 & 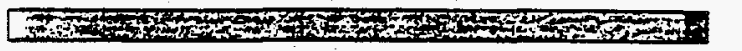 \\
\hline $222-S(1 A)$ & 90.93 & W is \\
\hline 324 SMF S & 84.18 & $x \rightarrow 3$ a \\
\hline 324 SMF E & 84.18 & 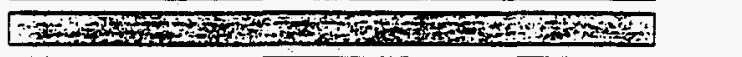 \\
\hline 327 B C D E & 83.6 & 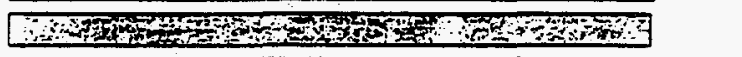 \\
\hline ORNL3047 B or C & 83.43 & 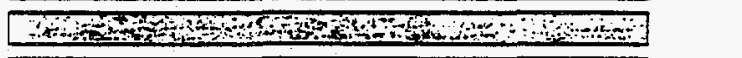 \\
\hline ORNL $3047 \mathrm{~A}$ or $\mathrm{D}$ & 83.43 & 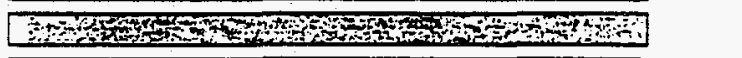 \\
\hline 324 RCE D & 82.58 & 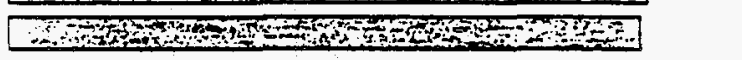 \\
\hline $324 \mathrm{RCE} C$ & 82.58 & 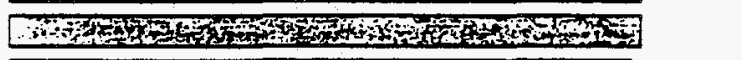 \\
\hline $222-S(1 E 2)$ & 81.39 & San \\
\hline $222-S(1 E I)$ & 81.39 & 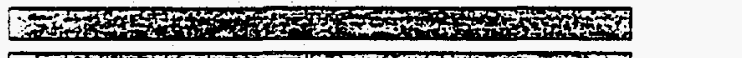 \\
\hline LANLWING9 & $81: 2$ & Forky \\
\hline ID ANA LAB & 80.09 & 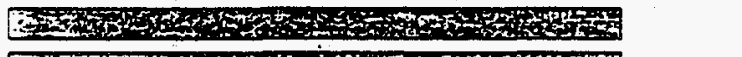 \\
\hline $327 \mathrm{G}$ & 80.03 & 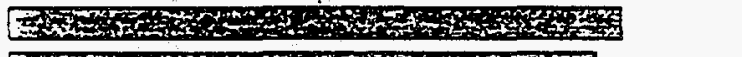 \\
\hline ID HFEF & 76.67 & Fond \\
\hline ORNL $4501 \mathrm{~B}$ or D & 76.61 & Wh \\
\hline ORNL3517 16 or 17 & 71.35 & 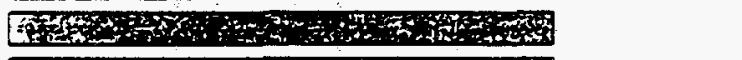 \\
\hline ORNL3517 15 & 71.35 & 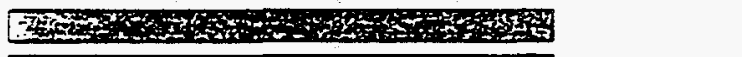 \\
\hline ORNL3517 14 & 71.35 & 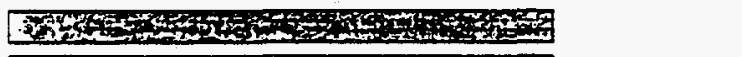 \\
\hline ORNL351711 & 71.35 & $P x x^{2}$ \\
\hline ORNL 351712 or 13 & 71.35 & 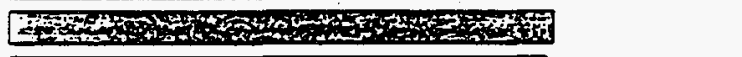 \\
\hline ID CPP666 & 70.4 & 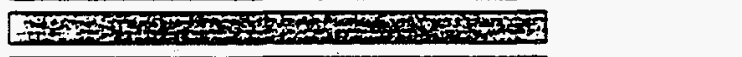 \\
\hline ID CPP601 & 70.4 & PNA \\
\hline WESF DE & 68.57 & 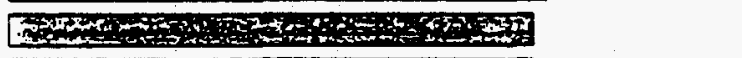 \\
\hline WESF B+C & 68.57 & 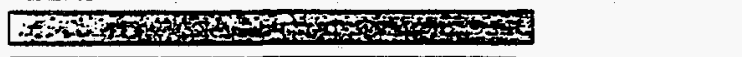 \\
\hline ANLE $200 \mathrm{KC}$ & 66.64 & 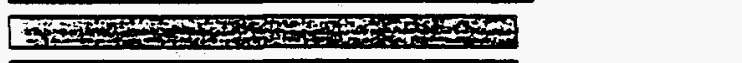 \\
\hline ANLE $200 \mathrm{AC}$ & 66.64 & 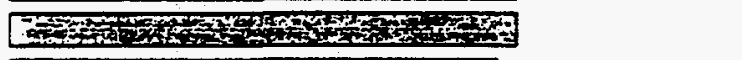 \\
\hline ID FCF & 64.02 & 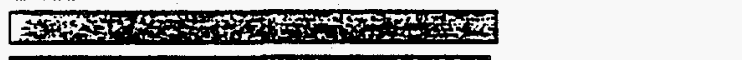 \\
\hline FMEF $135+4$ & 62.93 & 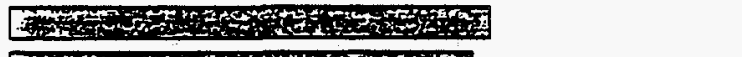 \\
\hline ID CPP684 & 60.87 & 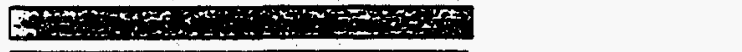 \\
\hline FMEF 507 & 60.23 & Fon \\
\hline FMEF 325 & 60.23 & 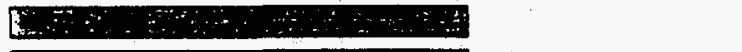 \\
\hline FMEF 147 & 60.23 & (n:? \\
\hline FMEF 146 & 60.23 & \\
\hline FMEF 145 & 60.23 & 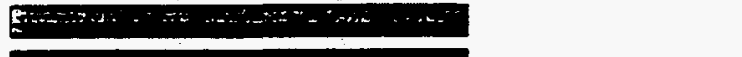 \\
\hline FMEF $132+6$ & 60.23 & \\
\hline ANLE $200 \mathrm{MC}$ & 57.1 & \\
\hline
\end{tabular}


Figure 4-5. Ranking of Hot Cells for Sludge Wash Group 3.

\begin{tabular}{|c|c|c|}
\hline Alternative & Value & \\
\hline $325 \mathrm{~A} \mathrm{~A}$ & 90.45 & 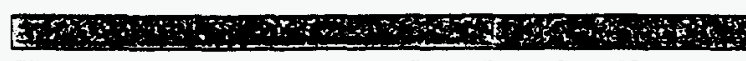 \\
\hline $325 \mathrm{~A} \mathrm{C}$ & 90.45 & 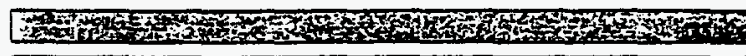 \\
\hline $325 \mathrm{SAL}$ & 90.45 & STH \\
\hline $222-S(11 A)$ & 89.33 & 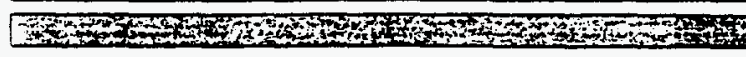 \\
\hline $222-S(1 \mathrm{~A})$ & 89.33 & 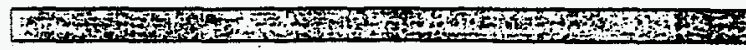 \\
\hline 324 SMF S & 84.18 & 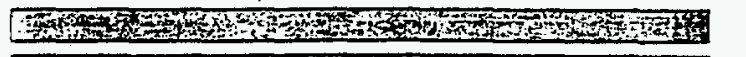 \\
\hline 324 SMF E & 84.18 & 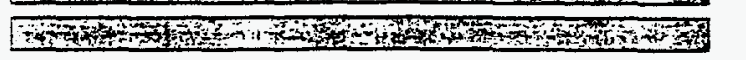 \\
\hline 324 RCE D & 84.18 & W \\
\hline $327 \mathrm{G}$ & 83.59 & 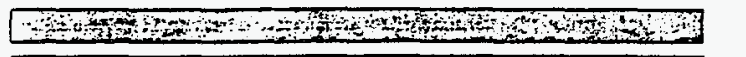 \\
\hline 327 B C D E & 83.59 & 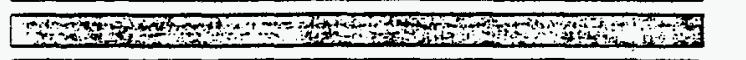 \\
\hline $222-S(1 F)$ & 82.98 & 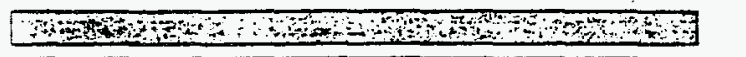 \\
\hline LANLWING9 & 82.8 & 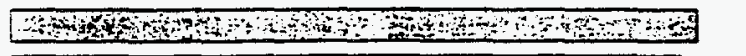 \\
\hline $325 \mathrm{~A} \mathrm{~B}$ & 80.91 & 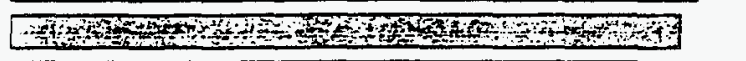 \\
\hline $222-S(1 E 1)$ & 79.8 & 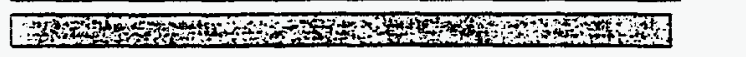 \\
\hline $222-S(1 E 2)$ & 79.8 & Fand \\
\hline ORNL3047 B or C & 78.65 & 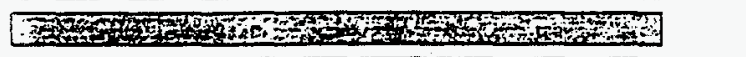 \\
\hline ORNL3047 A or D & 78.65 & 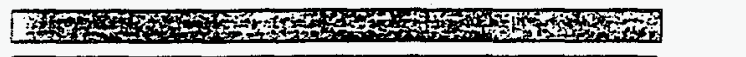 \\
\hline $324 \mathrm{RCE} \mathrm{C}$ & 77.82 & 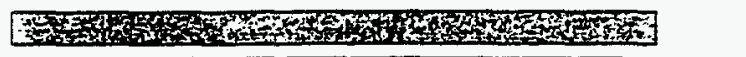 \\
\hline ID ANA LAB & 73.72 & A \\
\hline ID HFEF & 70.3 & 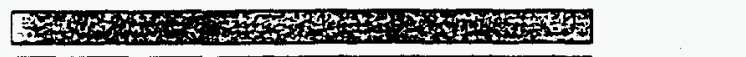 \\
\hline ORNL4501 B or D & 70.23 & 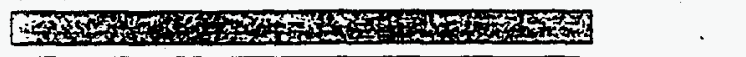 \\
\hline WESF DE & 68.57 & 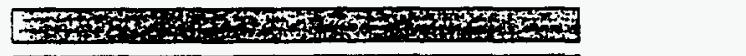 \\
\hline WESF $B+C$ & 68.57 & Fond \\
\hline ORNL 351716 or 17 & 66.56 & 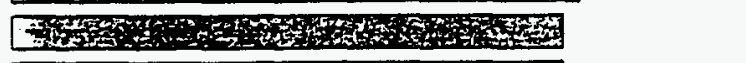 \\
\hline ORNL3517 15 & 66.56 & 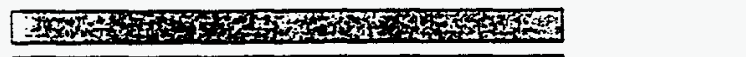 \\
\hline ORNL3517 14 & 66.56 & 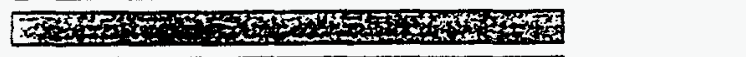 \\
\hline ORNL3517 11 & 66.56 & 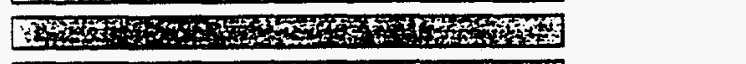 \\
\hline ORNL3517 12 or 13 & 66.56 & 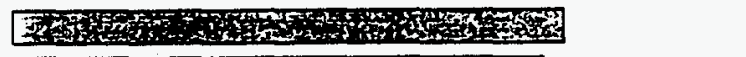 \\
\hline ID CPP666 & 64.03 & 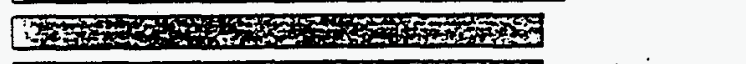 \\
\hline ID CPP601 & 64.03 & 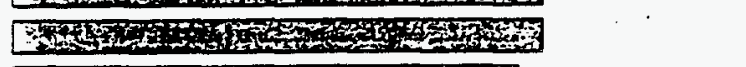 \\
\hline FMEF $135+4$ & 61.24 & 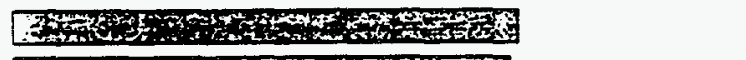 \\
\hline ANLE $200 \mathrm{KC}$ & 60.28 & Tys \\
\hline ANLE $200 \mathrm{AC}$ & 60.28 & 两 \\
\hline ID FCF & 57.65 & F \\
\hline ANLE $200 \mathrm{MC}$ & 57.1 & 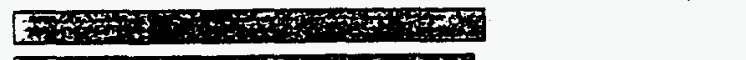 \\
\hline FMEF 507 & 55.83 & Fs: \\
\hline FMEF 325 & 55.83 & 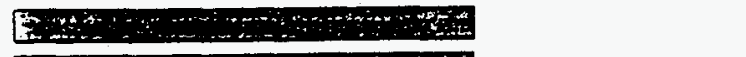 \\
\hline FMEF 147 & 55.83 & \\
\hline FMEF 146 & 55.83 & $8: ?$ \\
\hline FMEF 145 & 55.83 & 整是 \\
\hline FMEF $132+6$ & 55.83 & \\
\hline ID CPP684 & 54.49 & \\
\hline
\end{tabular}


WHC-SD-WM-TA-160

Revision 0

Figure 4-6. Ranking of Hot Cells for Sludge Wash Group 4.

\begin{tabular}{|c|c|c|}
\hline Alternative & Value & \\
\hline $325 \mathrm{~A} \mathrm{C}$ & 89.49 & 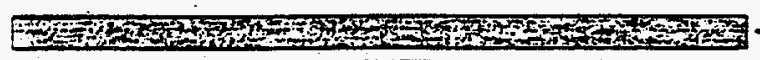 \\
\hline $325 \mathrm{SAL}$ & 89.49 & 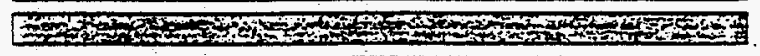 \\
\hline $222-S(1 F)$ & 89.33 & 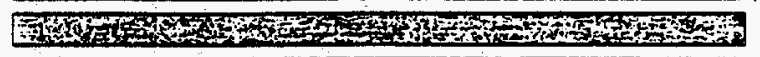 \\
\hline $222-S(11 \mathrm{~A})$ & 89.33 & 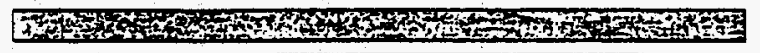 \\
\hline $222-S(1 A)$ & 89.33 & 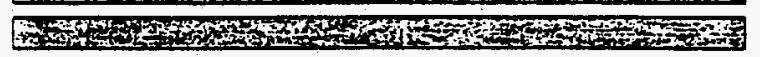 \\
\hline $325 \mathrm{~A} \mathrm{~A}$ & 87.89 & Y) \\
\hline 324 SMF S & 84.18 & FAn \\
\hline 324 SIMF E & 84.18 & Wis \\
\hline 324 RCE D & 84.18 & 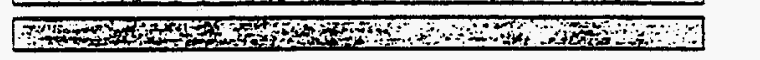 \\
\hline $324 \mathrm{RCE} \mathrm{C}$ & 84.18 & तNA3 \\
\hline ORNL3047 B or C & 83.43 & 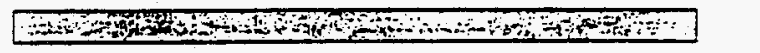 \\
\hline ORNL3047 A or D & 83.43 & 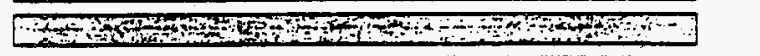 \\
\hline LANLWING9 & 82.8 & 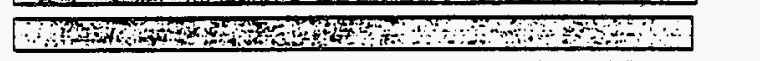 \\
\hline $327 \mathrm{G}$ & 80.03 & Faris \\
\hline $327 \mathrm{~B} \mathrm{C} \mathrm{DE}$ & 80.03 & 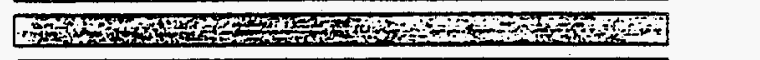 \\
\hline $325 \mathrm{~A}$ B & 79.95 & 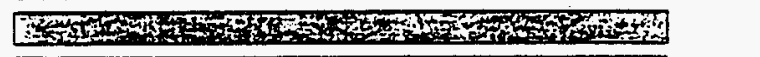 \\
\hline $222-S(1 E 1)$ & 79.8 & 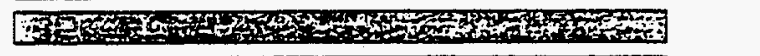 \\
\hline 222-S(IE2) & 79.8 & Fo' \\
\hline ID ANA LAB & 78.5 & 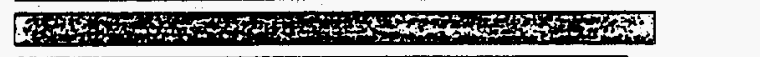 \\
\hline ID HFEF & 75.08 & 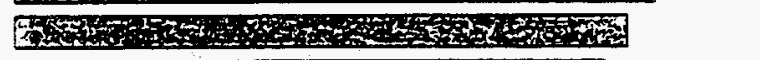 \\
\hline ORNL4501 B or D & 72.46 & Erats \\
\hline ORNL 351716 or 17 & 71.35 & 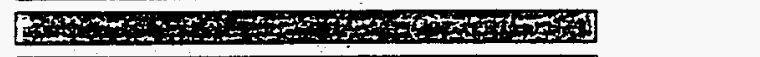 \\
\hline ORNL.3517 15 & 71.35 & 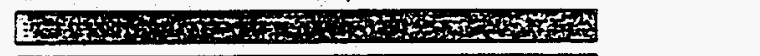 \\
\hline ORNL3517 14 & 71.35 & 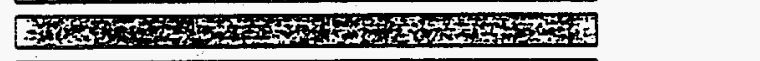 \\
\hline ORNL351711 & 71.35 & 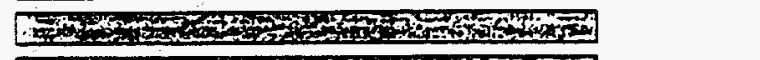 \\
\hline ORNL 351712 or 13 & 71.35 & 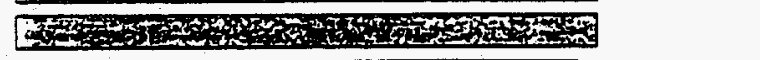 \\
\hline ID CPP666 & 68.81 & 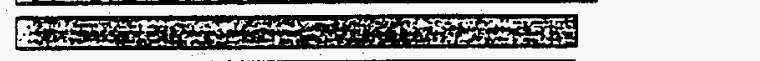 \\
\hline WESF DE & 68.57 & Zurg \\
\hline WESF B+C & 68.57 & 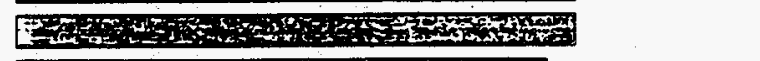 \\
\hline ANLE $200 \mathrm{KC}$ & 65.06 & 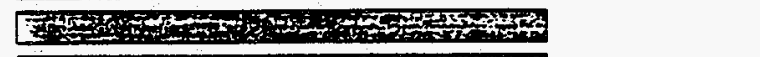 \\
\hline ANLE $200 \mathrm{AC}$ & 65.06 & 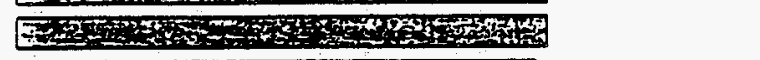 \\
\hline ID CPP601 & 63.62 & 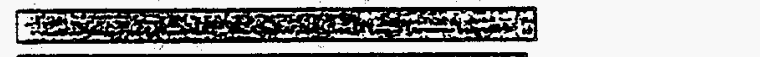 \\
\hline ID FCF & 62.43 & 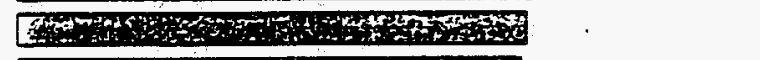 \\
\hline ANLE $200 \mathrm{MC}$ & 61.89 & 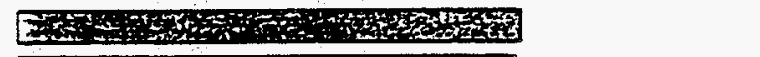 \\
\hline FMEF .135+4 & 61.24 & 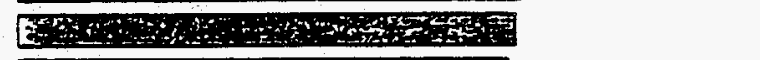 \\
\hline FMEF 507 & 60.38 & F \\
\hline FMEF 325 & 60.38 & $\therefore 2$ \\
\hline FMEF 147 & 60.38 & $2+2$ \\
\hline FMEF 146 & 60.38 & $4:-7: 9$ \\
\hline FMEF 145 & 60.38 & \\
\hline FMEF $132+6$ & 60.38 & \\
\hline ID CPP684 & 59.27 & \\
\hline
\end{tabular}


Figure 4-7. Ranking of Hot Cells for Organic Destruction Group 1.

\begin{tabular}{|c|c|c|}
\hline Altemative & Value & \\
\hline 222-S(IF) & 86.16 & 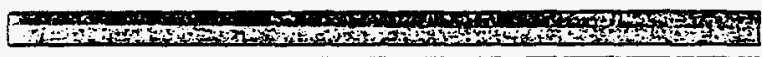 \\
\hline $222-S(11 \mathrm{~A})$ & 86.16 & 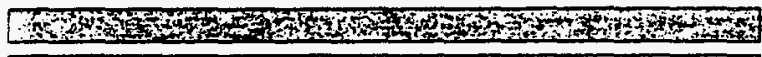 \\
\hline $222-S(1 A)$ & 86.16 & 737 \\
\hline $325 \mathrm{~A} \mathrm{~A}$ & 85.68 & 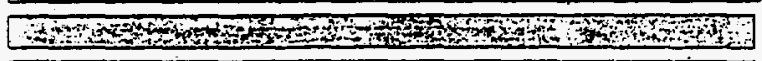 \\
\hline $325 \mathrm{~A} \mathrm{C}$ & 85.68 & 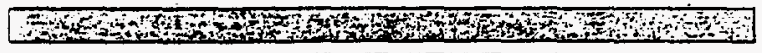 \\
\hline $325 \mathrm{SAL}$ & 85.68 & 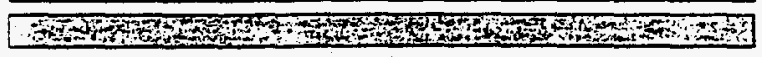 \\
\hline ORNL $4501 \mathrm{~B}$ or D & 83.43 & 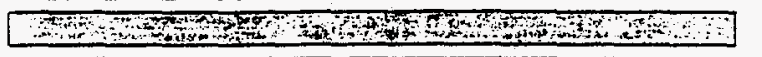 \\
\hline ORNL3047 B or C & 83.43 & 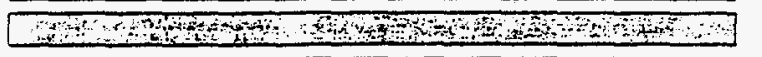 \\
\hline ORNL3047 A or D & 83.43 & 72, \\
\hline $222-S(1 E 2)$ & 82.99 & 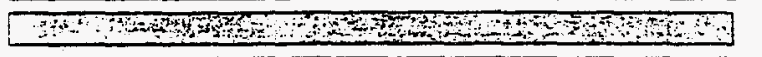 \\
\hline $222-S(\mid E I)$ & 82.99 & 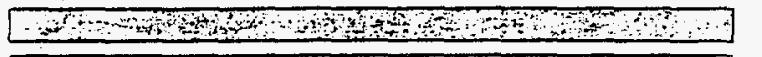 \\
\hline LANLWING9 & 82.8 & 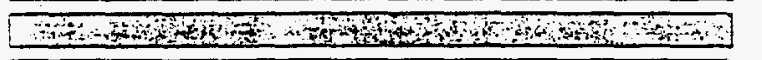 \\
\hline $325 \mathrm{~A} \mathrm{~B}$ & 82.51 & 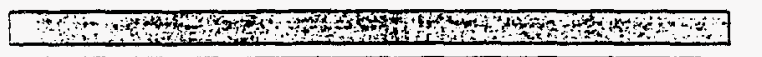 \\
\hline 324 SMF S & 79.41 & 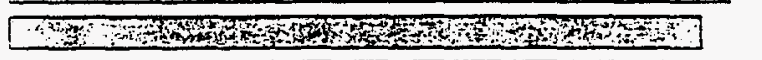 \\
\hline 324 SMF E & 79.41 & 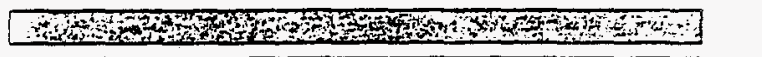 \\
\hline 324 RCE D & 79.41 & 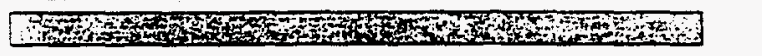 \\
\hline 324 RCE C & 79.41 & 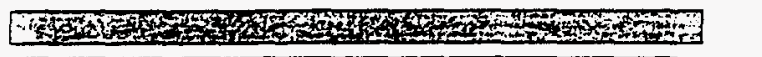 \\
\hline ID HFEF & 76.67 & 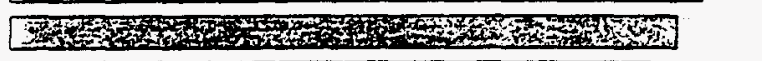 \\
\hline $327 \mathrm{G}$ & 73.67 & 78 \\
\hline 327 B C D E & 73.67 & 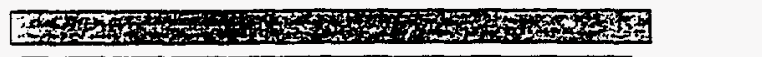 \\
\hline ORNL3517 16 or 17 & 71.35 & 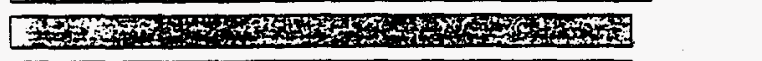 \\
\hline ORNL3517 15 & 71.35 & 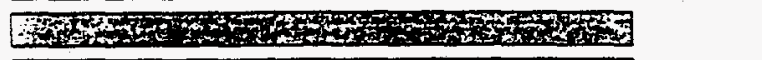 \\
\hline ORNL351714 & 71.35 & S- \\
\hline ORNL3517 il & 71.35 & 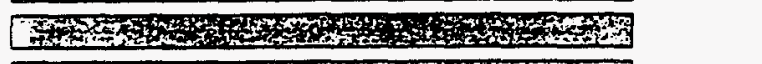 \\
\hline ORNL3517 12 or 13 & 71.35 & 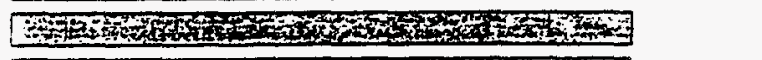 \\
\hline ID ANA LAB & 71.18 & 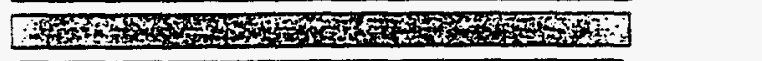 \\
\hline ID CPP684 & 70.4 & 7 \\
\hline ID CPP666 & 70.4 & 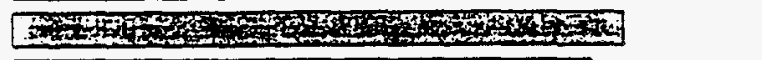 \\
\hline ID CPP601 & 66.76 & 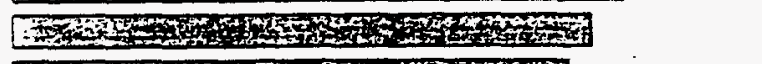 \\
\hline ID FCF & 64.02 & FA \\
\hline ANLE $200 \mathrm{KC}$ & 60.54 & 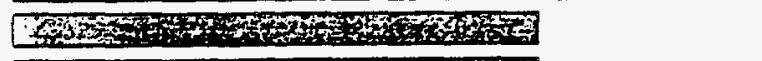 \\
\hline ANLE $200 \mathrm{AC}$ & 60.54 & 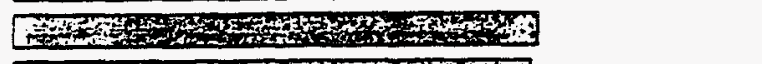 \\
\hline WESF DE & 59.79 & 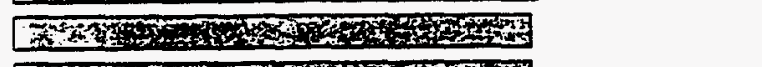 \\
\hline WESF B+C & 59.79 & G \\
\hline FMEF $135+4$ & 57.67 & 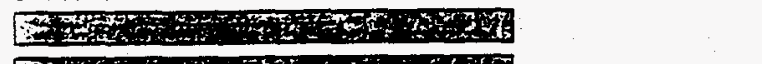 \\
\hline FMEF 507 & 57.67 & 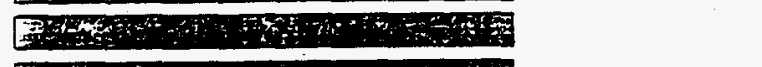 \\
\hline FMEF 325 & 57.67 & En: \\
\hline FMEF 147 & 57.67 & Esistion: \\
\hline FMEF 146 & 57.67 & 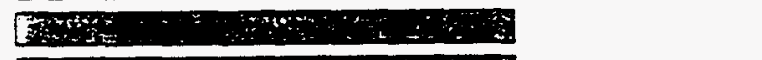 \\
\hline FMEF 145 & 57.67 & 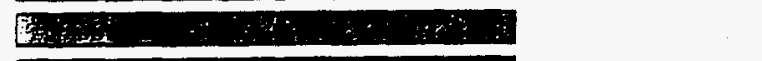 \\
\hline FMEF $132+6$ & $57.67^{\circ}$ & F \\
\hline ANLE $200 \mathrm{MC}$ & 57.36 & \\
\hline
\end{tabular}




$$
\begin{gathered}
\text { WHC-SD-WM-TA-160 } \\
\text { Revision } 0
\end{gathered}
$$

\begin{tabular}{|c|c|c|}
\hline Alternative & Value & \\
\hline $325 \mathrm{~A} \mathrm{C}$ & 89.13 & 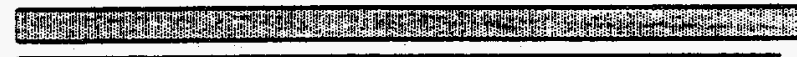 \\
\hline $325 \mathrm{SAL}$ & 87.11 & 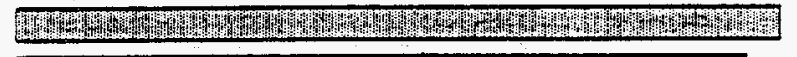 \\
\hline ORNL3047 A or D & 83.12 & 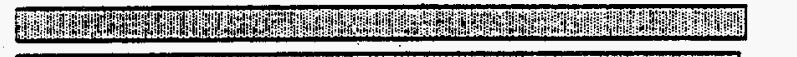 \\
\hline $325 \mathrm{~A} \mathrm{~A}$ & 82.51 & 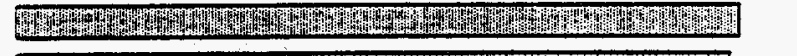 \\
\hline $222-S(1 F)$ & 81.39 & 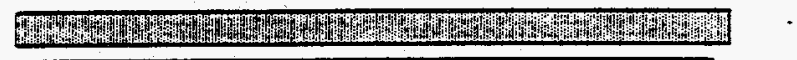 \\
\hline $325 \mathrm{~A} \mathrm{~B}$ & 79.6 & 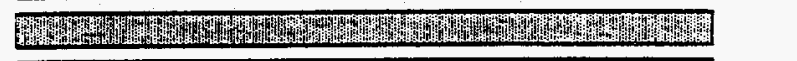 \\
\hline 222-S(1E1) & 79.56 & 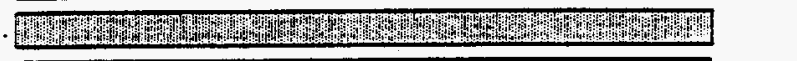 \\
\hline LANLWING9 & 79.37 & 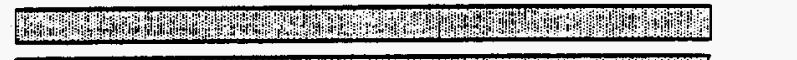 \\
\hline 222-S(1E2) & 79.11 & 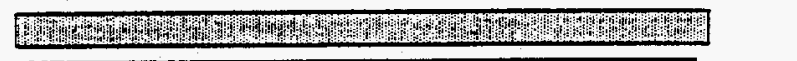 \\
\hline 324 SMF S & 77.82 & 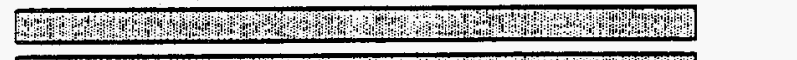 \\
\hline 324 SMF E & 77.82 & 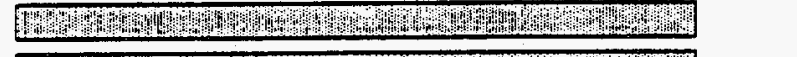 \\
\hline 324 RCE D & 77.82 & 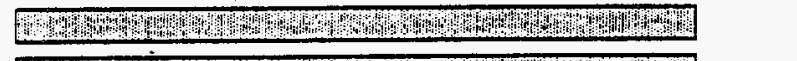 \\
\hline 324 RCE C & 77.82 & 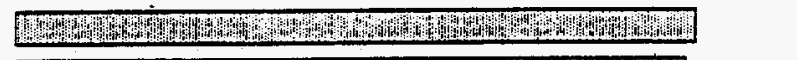 \\
\hline ID HFEF & 76.67 & 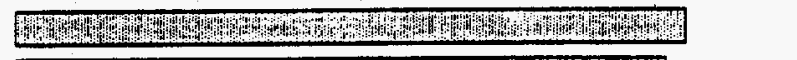 \\
\hline ORNL $4501 \mathrm{~B}$ or $\mathrm{D}$ & 74.53 & 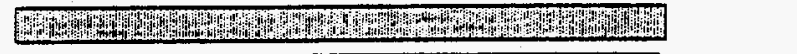 \\
\hline ORNL3047 B or C & 73.9 & 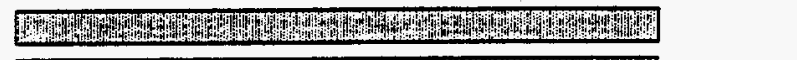 \\
\hline $327 \mathrm{G}$ & 73.67 & 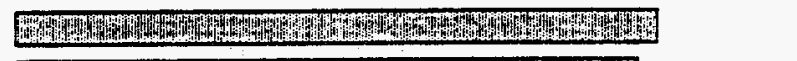 \\
\hline ORNL3517 15 & 71.35 & 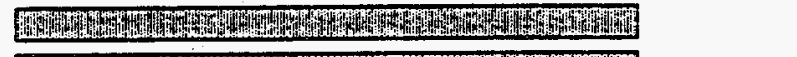 \\
\hline ORNL3517 14 & 71.35 & 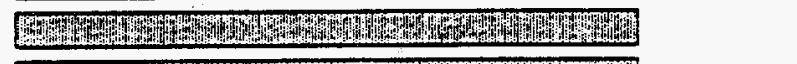 \\
\hline ORNL3517 11 & 71.35 & 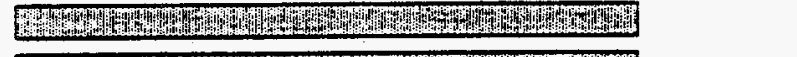 \\
\hline ORNL3517 12 or 13 & 71.35 & 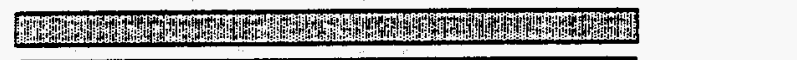 \\
\hline ID ANA LAB & 71.18 & 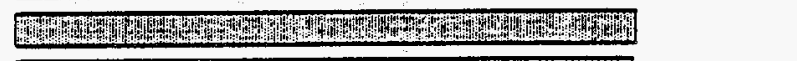 \\
\hline ORNL3517 16 or 17 & 71.03 & 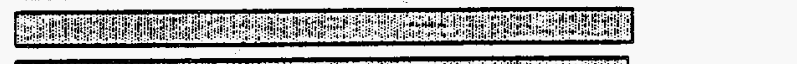 \\
\hline ID CPP666 & 70.4 & 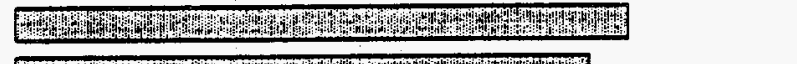 \\
\hline WESF DE & 66.02 & 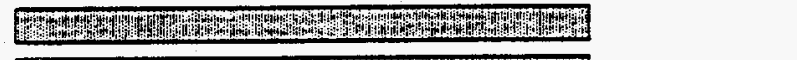 \\
\hline WESF $B+C$ & 66.02 & 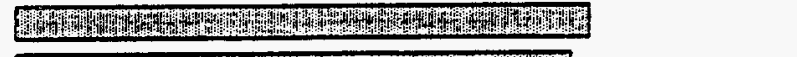 \\
\hline ID FCF & 64.02 & 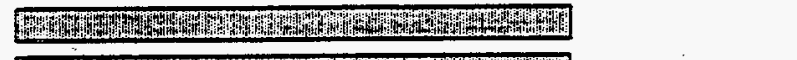 \\
\hline FMEF $134 \div 4$ & 63.79 & 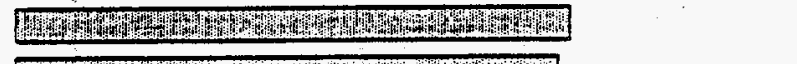 \\
\hline FEMF 507 & 62.45 & 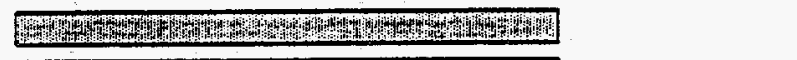 \\
\hline FMEF 325 & 62.45 & 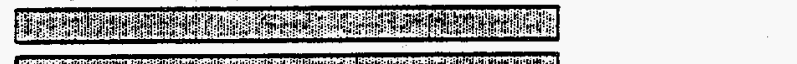 \\
\hline FMEF 235 & 62.45 & 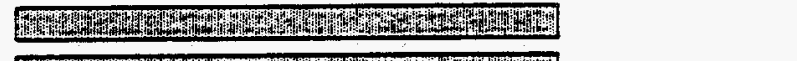 \\
\hline FMEF 147 & 62.45 & 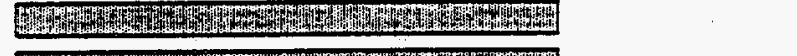 \\
\hline FMEF 146 & 62.45 & 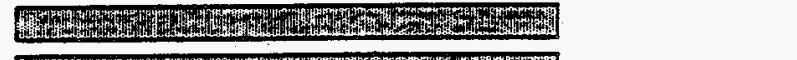 \\
\hline FMEF 145 & 62.45 & 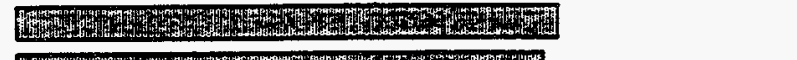 \\
\hline ID CPP684 & 60.87 & 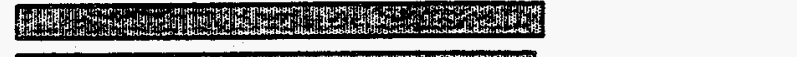 \\
\hline FMEF $132 \div 6$ & 60.07 & 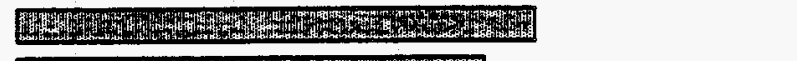 \\
\hline ANLE $200 \mathrm{KC}$ & 54.16 & 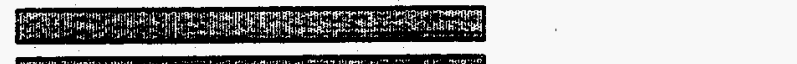 \\
\hline ANLE $200 \mathrm{AC}$ & 54.16 & 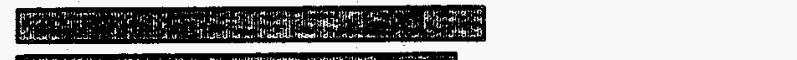 \\
\hline ANLE $200 \mathrm{MC}$ & 50.98 & 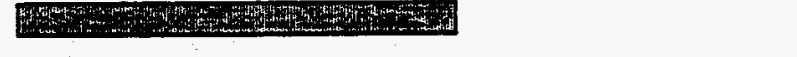 \\
\hline
\end{tabular}

Figure 4-8. Ranking of'Hot Cells for Settle/Decant-1. 
Figure 4-9. Ranking of Hot Cells for Filtration Group 1.

$\begin{array}{lc}\text { Alternative } & \text { Value } \\ \text { 325A C } & 87.99 \\ \text { 325A A } & 85.68 \\ \text { 222-S (1F) } & 84.57 \\ \text { 324 SMF S } & 84.18 \\ \text { 324 SMF E } & 84.18 \\ \text { 324 RCE D } & 84.18 \\ \text { 324 RCE C } & 84.18 \\ \text { 325A B } & 81.63 \\ \text { 327 G } & 79.18 \\ \text { WESF DE } & 62.34 \\ \text { WESF B+C } & 62.34 \\ \text { FMEF 507 } & 60.12 \\ \text { FMEF 325 } & 60.12 \\ \text { FMEF 147 } & 60.12\end{array}$

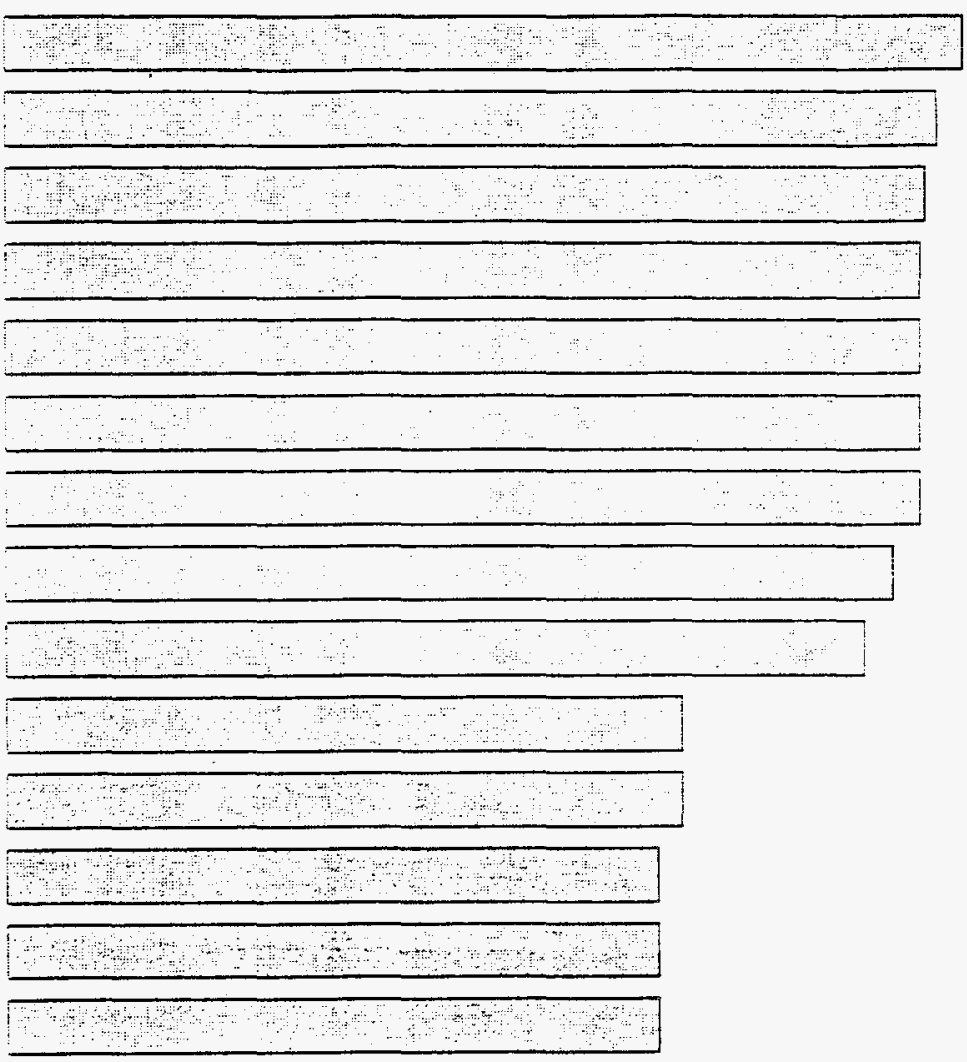


WHC-SD-WM-TA-160

Revision 0

Figure 4-10. Ranking of Hot Cells for Filtration Group 2.

$\begin{array}{ll}\text { Alternative } & \text { Value } \\ \text { 325A A } & 93.75 \\ \text { 324 RCE D } & 88.19 \\ \text { 324 RCE C } & 86.6 \\ \text { 324 SMF S } & 84.03 \\ \text { 324 SMF E } & 84.03 \\ \text { WESF DE } & 75.06 \\ \text { WESF B+C } & 71.63 \\ \text { FMEF 147 } & 60.26 \\ \text { FMEF 507 } & 59\end{array}$

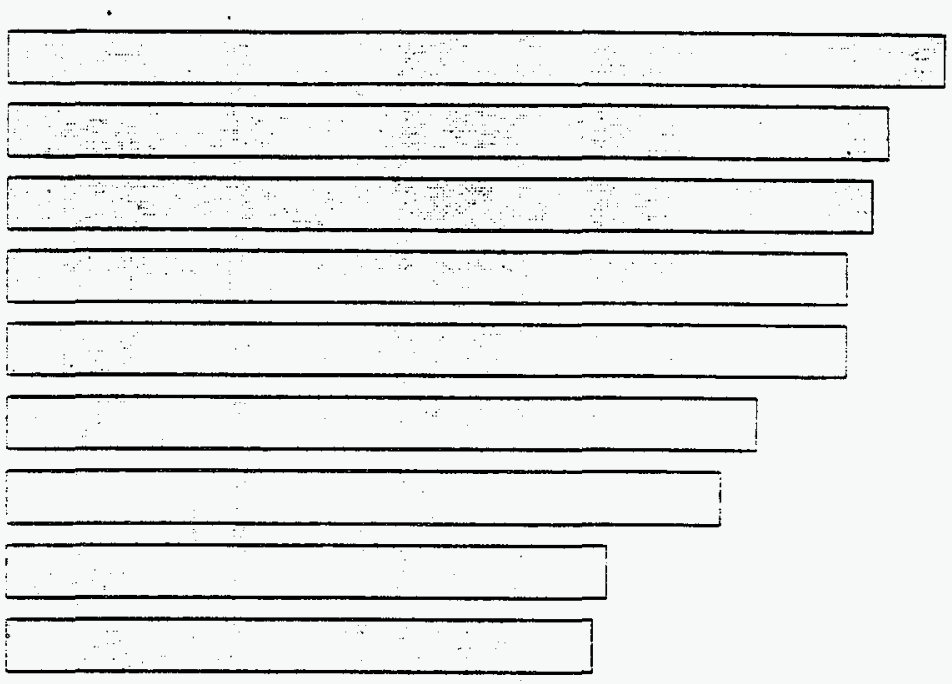


WHC-SD-WM-TA-160

Revision 0

Figure 4-11. Ranking of Hot Cells for Filtration Group 3.

Alternative Value

$325 \mathrm{~A} A$

222-S $(1 \mathrm{~F})$

94.08

324 RCE D

91.93

$324 \mathrm{RCE} C$

87.35

87.35

324 SMF S

84.8

324 SMF E

WESF DE

84.8

WESF $B+C$

75.06

FMEF 147

69.56

FMEF 507

63.3

60.12

FMEF 325

60.12

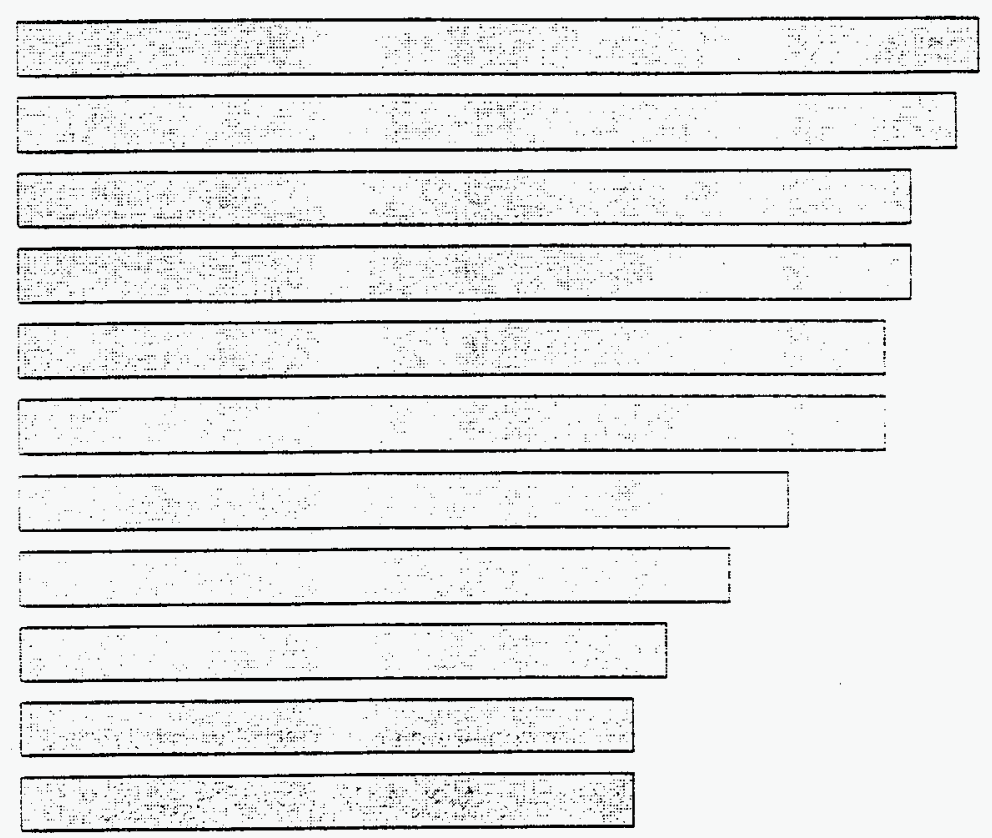


WHC-SD-WM-TA-160

Revision 0

Figure 4-12. Ranking of Hot Cells for Centrifugation.

$\begin{array}{ll}\text { Alternative } & \text { Value } \\ \text { 325A A } & 91.48 \\ \text { 222-S(1F) } & 89.64 \\ \text { 324 RCE D } & 87.35 \\ \text { 324 RCE C } & 87.35 \\ \text { 324 SMF S } & 84.8 \\ \text { 324 SMF E } & 84.8 \\ \text { WESF DE } & 74.04 \\ \text { WESF B+C } & 73.53 \\ \text { FMEF 147 } & 59.73 \\ \text { FMEF 507 } & 56.55 \\ \text { FMEF 325 } & 56.55\end{array}$

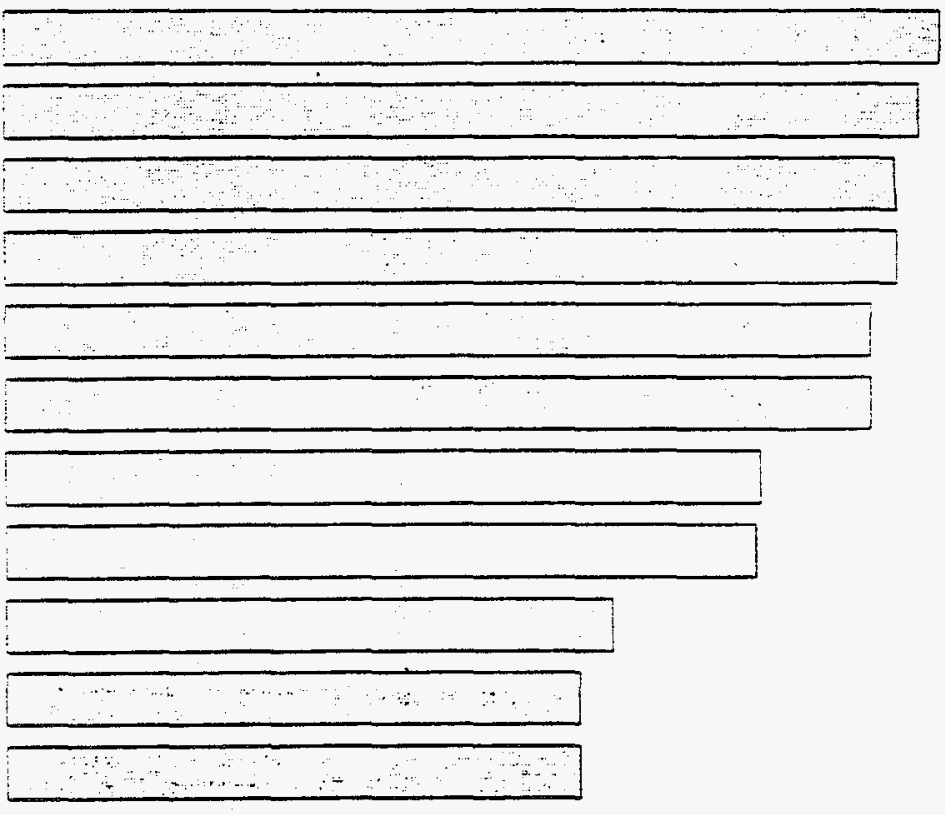

least flexible in fitting in with other work, and would need the most time to set up and operate. Therefore, they were spotted first and the others fit into the rest of the available cells based on their relative ranking. The basic rule of the exercise was that once a cell was assigned, it was no longer on the "availability" list even though the decision analysis for other (usually lower ranked) test groupings may also identify that cell as first choice. In that case, the next lower ranked and available cell was assigned. Exceptions to the logic applied in developing cell assignment recommendations are noted in Table 4-2.

Table 4-2 displays the results of this effort with the more difficult test setups at the top of the page, listed in descending order of complexity.

\subsubsection{Logic Exceptions}

As noted, two exceptions were made to the assignment logic. First, a cell to house the $25-L$ sampler servicing and transhipment function was considered a high priority due to its space and special cask access requirements, but it was not believed by the evaluation team to warrant one of the most highly ranked cells, such as Building 325A, Cell $\mathrm{A}$. Second, the Filtration Group 2 test is a performance test of the transuranic (TRU) monitor instrument development. While the volume of waste identified as needed to perform that test is larger than even the ion-exchange Case 2 test requirement, a measure of uncertainty about the future of the instrument led the evaluation team to rank it below the importance of the two ion-exchange test groups for cell assignment. 
Table 4-2. Test Group Siting Recommendations. (sheet 1 of 2)

\begin{tabular}{|c|c|c|c|c|c|c|c|}
\hline $\begin{array}{l}\text { Pretreatment } \\
\text { technology } \\
\text { infrastructure }\end{array}$ & $\begin{array}{l}\text { Test } \\
\text { group }\end{array}$ & $\begin{array}{l}\text { Sample } \\
\text { size/test } \\
\text { run }\end{array}$ & $\begin{array}{l}\text { Mo. test } \\
\text { runs/start } \\
\text { date }\end{array}$ & $\begin{array}{l}\text { Recommended test/ } \\
\text { infrastructure } \\
\text { location. }\end{array}$ & $\begin{array}{l}\text { First backup } \\
\text { location }\end{array}$ & Comments ${ }^{\star}$ & $\begin{array}{l}\text { Logic of exceptions to decision } \\
\text { analysis ranking of facilities }\end{array}$ \\
\hline $\begin{array}{l}25-L \text { sampler } \\
\text { service } \\
\text { facility }\end{array}$ & -- & $\cdots$ & $7 / 96$ & $\begin{array}{l}\text { Bldg } 324 \text { RCE } \\
\text { Cell C }\end{array}$ & WESF B \& C & $\begin{array}{l}\text { *If not used for ion } \\
\text { exchange Case } 2 \text {. No RCRA } \\
\text { required. Include in } \\
\text { NEPA. Hay require air } \\
\text { permit. }\end{array}$ & $\begin{array}{l}\text { Best access for cask handling, } \\
\text { sampler unl oading, and } \\
\text { maintenance. }\end{array}$ \\
\hline \multirow{2}{*}{$\begin{array}{l}\text { lon-exchange } \\
\text { Case } 2\end{array}$} & \multirow[t]{2}{*}{2} & \multirow[t]{2}{*}{$3,600 \mathrm{~L}$} & $3-9$ & \multirow{2}{*}{$\begin{array}{l}\text { Bldg } 325 A \\
\text { Cells } A+B+C\end{array}$} & \multirow{2}{*}{$\begin{array}{l}\text { Bldg } 322^{\circ} \text { RCE } \\
\text { Cell C }\end{array}$} & \multirow{2}{*}{$\begin{array}{l}\text { RCRA - } 1 \text { year for ROSD } \\
\text { permit. NEPA and air } \\
\text { required. }\end{array}$} & \multirow[t]{2}{*}{-- } \\
\hline & & & $10 / 96$ & & & & \\
\hline \multirow{2}{*}{$\begin{array}{l}\text { Ion-exchange } \\
\text { Case } 1\end{array}$} & \multirow{2}{*}{1} & \multirow[t]{2}{*}{$180 \mathrm{~L}$} & $3-9$ & \multirow{2}{*}{$\begin{array}{l}\text { Bldg 325A } \\
\text { Cell A }\end{array}$} & \multirow{2}{*}{$\begin{array}{l}\text { Bldg } 325 \mathrm{~A} \\
\text { Cells B \& C }\end{array}$} & \multirow{2}{*}{$\begin{array}{l}\text { RCRA treatability study. } \\
\text { NEPA and air review. }\end{array}$} & \multirow{2}{*}{$\begin{array}{l}\text { Potential for consolidation with } \\
\text { test group ion-exchange Case } 2 \text {. } \\
\text { Group } 1 .\end{array}$} \\
\hline & & & $10 / 96$ & & & & \\
\hline \multirow{2}{*}{$\begin{array}{l}\text { Filtration } \\
\text { (TRU monitor) }\end{array}$} & \multirow[t]{2}{*}{2} & \multirow{2}{*}{4,0001} & 1 & \multirow{2}{*}{$\begin{array}{l}\text { Bldg } 324 \text { RCE } \\
\text { Cell D }\end{array}$} & \multirow{2}{*}{ WESF B \& C } & \multirow{2}{*}{$\begin{array}{l}\text { No RCRA required. NEPA } \\
\text { and air evaluation needed. }\end{array}$} & \multirow{2}{*}{$\begin{array}{l}\text { First choice Cell } 325 A \text { - Cell A } \\
\text { assigned to ion-exchange Case } 2 \text {. } \\
\text { Second candidate, } 324 \text { SMF, not } \\
\text { used in favor of WESF because } \\
\text { design for WESF available; } 324 \text { SHF } \\
\text { more useful for other tests. }\end{array}$} \\
\hline & & & $10 / 96$ & & & & \\
\hline \multirow[t]{2}{*}{ Centrifugation } & \multirow[t]{2}{*}{1} & \multirow[t]{2}{*}{$100-500 \mathrm{~L}$} & 4 & \multirow{2}{*}{$\begin{array}{l}\text { Bldg 222-s } \\
\text { Cell 1F }\end{array}$} & \multirow{2}{*}{$\begin{array}{l}\text { Bldg } 324 \text { SMF- } \\
\text { East Cell }\end{array}$} & \multirow[t]{2}{*}{-. } & \multirow[t]{2}{*}{ - } \\
\hline & & & $10 / 96$ & & & & \\
\hline \multirow[t]{2}{*}{ Filtration } & \multirow[t]{2}{*}{3} & \multirow{2}{*}{$100 L / 25 L$} & $5 / 5$ & \multirow{2}{*}{$\begin{array}{l}\text { Bldg } 324 \text { SMF-East } \\
\text { Cell }\end{array}$} & \multirow{2}{*}{$\begin{array}{l}\text { Bldg } 324 \text { SMF- } \\
\text { South Cell }\end{array}$} & \multirow[t]{2}{*}{$\cdots$} & \multirow[t]{2}{*}{--} \\
\hline & & & $10 / 96 \& 7 / 96$ & & & & \\
\hline filtration & 1 & $1 \mathrm{~L} / 25 \mathrm{~L}$ & $5 / 5$ & Bldg 324 SMF-East & $\begin{array}{l}\text { Bldg } 324 \text { SMF- } \\
\text { South }\end{array}$ & $\begin{array}{l}\text { "If cell c not used for } \\
\text { ion-exchange Case ?. } \\
\text { Group } 1 .\end{array}$ & $\begin{array}{l}\text { Locate in same cell as filtration, } \\
\text { Group } 3 \text {. Use some of same } \\
\text { equipment. Part of Group } 1 \text { could }\end{array}$ \\
\hline & & & $7 / 95 \& 7 / 96$ & & & & $\begin{array}{l}\text { needed. Part of Group } 1 \text { and all } \\
\text { of Group } 3 \text { del ayed until July/Oct } \\
1998 \text { Häiting for large samples. }\end{array}$ \\
\hline Ion-exchange & 2 & $15 \mathrm{~L} / 150 \mathrm{~mL}$. & $10 / 4$ & Btdg 222-s & BIdg 324 SMF- & $-\cdot$ & -- \\
\hline & & & $7 / 96 \& 6 / 95$ & & & & \\
\hline Organic & 1 & $100 \mathrm{~mL} / 10 \mathrm{~L}$ & $15 / 1$ & Bidg $222-s$ & Bldg 222-S-1A & -. & $-\cdot$ \\
\hline zation & & & $1 / 95 \& 7 / 96$ & & & & \\
\hline Settle/decant & 1 & $2-41$ & 5 & Bldg 3258 & ORNL BIdg 3047 & -- & 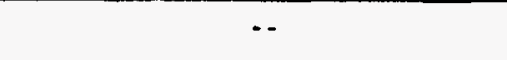 \\
\hline & & & $7 / 96$ & & & & \\
\hline
\end{tabular}


Table 4-2. Test Group Siting Recommendations. (sheet 2 of 2)

\begin{tabular}{|c|c|c|c|c|c|c|c|}
\hline $\begin{array}{l}\text { Pretreatment } \\
\text { technology } \\
\text { infrestructure }\end{array}$ & $\begin{array}{l}\text { Jest } \\
\text { group }\end{array}$ & $\begin{array}{l}\text { Sample } \\
\text { sixe/test } \\
\text { run }\end{array}$ & $\begin{array}{l}\text { Ho. test } \\
\text { runs/start } \\
\text { date }\end{array}$ & $\begin{array}{l}\text { Recommended test/ } \\
\text { infrastructure } \\
\text { location }\end{array}$ & $\begin{array}{l}\text { first backup } \\
\text { location }\end{array}$ & Corments s* & $\begin{array}{l}\text { Logic of exceptions to decision } \\
\text { analysis ranking of facilities }\end{array}$ \\
\hline \multirow[t]{2}{*}{ sludge wash } & \multirow[t]{2}{*}{1} & \multirow[t]{2}{*}{$40 \mathrm{~g}$} & 30 & \multirow[t]{2}{*}{$\begin{array}{l}\text { LAHL Hing } 9 \text { and } \\
\text { PNL }\end{array}$} & \multirow[t]{2}{*}{$\begin{array}{l}\text { Bldg 222-S } \\
\text { Cell iA }\end{array}$} & \multirow[t]{2}{*}{$-\cdot$} & \multirow{2}{*}{$\begin{array}{l}\text { Hork in progress at LANL Ning } 9 . \\
\text { Staff ing and work initiation } \\
\text { completed since } 12 / 1 / 94 \text {, otherwise } \\
\text { would have recommended } 222-\mathrm{s} \\
\text { Cell } 1 \mathrm{~A} \text {. }\end{array}$} \\
\hline & & & $12 / 94$ & & & & \\
\hline \multirow[t]{2}{*}{ sludge wash } & \multirow[t]{2}{*}{3} & \multirow[t]{2}{*}{$10 \mathrm{~mL}$} & 18 & \multirow{2}{*}{$\begin{array}{l}\text { LANL Hing } 9 \text { and } \\
\text { PNL }\end{array}$} & \multirow[t]{2}{*}{$\begin{array}{l}\text { Bldg } 222-s \\
\text { Cell iA }\end{array}$} & \multirow[t]{2}{*}{$\cdots$} & \multirow{2}{*}{$\begin{array}{l}\text { Hork in progress at LAML Wing } 9 . \\
\text { Staffing and work init lation } \\
\text { completed since } 12 / 1 / 94 \text {, otherwise } \\
\text { would have recommended } 222-\mathrm{s} \\
\text { cell } 1 \mathrm{~A} \text {. }\end{array}$} \\
\hline & & & $12 / 94$ & & & & \\
\hline \multirow[t]{2}{*}{ Sludge mash } & \multirow[t]{2}{*}{4} & \multirow[t]{2}{*}{$20 \mathrm{~mL}$} & 18 & \multirow{2}{*}{$\begin{array}{l}\text { LANL Ning } 9 \text { and } \\
\text { PNL }\end{array}$} & \multirow{2}{*}{$\begin{array}{l}\text { 8ldg 222-s } \\
\text { Cell 1A }\end{array}$} & \multirow[t]{2}{*}{$-\cdot$} & \multirow{2}{*}{$\begin{array}{l}\text { Work in progress at LAKL Wing } 9 . \\
\text { staffing and work initiation } \\
\text { completed since } 12 / 1 / 94 \text { otherwise } \\
\text { would have recommended } 222-5 \\
\text { Cell IA. }\end{array}$} \\
\hline & & & $12 / 94$ & & & & \\
\hline
\end{tabular}

LANL = Los Alamos National Laboratory

i $\quad$ MEPA $=$ Mational Environmental Policy Act of 1969

ORHL $=$ Oak Ridge Hat ional Laboratory

PHL $=$ Paciflc Morthwest Laboratory

RCE = Radiochemical engineering

RCRA = Resource Conservation and Recovery Act of 1976

RD\&D = Research, development, and demonstration

SMF = Shielded Materials Facility

WESF = Maste Encapsulation and Storage Facility 
WHC-SD-WM-TA-160

Revision 0

\subsubsection{Ion-Exchange Testing}

Considering these exceptions, the evaluation team debated the needs of the ion-exchange Case 2 and Case 1 testing simultaneously with the needs of the 25- $L$ sampler in arriving at the recommended cell assignments for those functions.

The test scenario for the ion-exchange test work was to perform $10-\mathrm{mL}$ cold ion-exchange column testing followed by $10-\mathrm{mL}$ hot testing of the resins. If successful, a $200-\mathrm{mL}$ cold test would be performed. If that proved successful, a full-scale cold test would be performed. If the 200-mL cold test identified problem areas or further uncertainty, the tests would be repeated at 200-mL scale using actual waste. As a result, it is recommended that the 325A Building, Cells $A, B$, and $C$, be committed to the ion-exchange test work. The cells initially will be set up to do the 10-mL column test, but with tankage installed in those cells to receive and handle samples for 200-mL column testing should that level of testing be required.

As noted in Table 4-2, the 10-mL test should fall in the range of a TS whereas the 200-mL tests will require an RD\&D permit, which takes about a year to obtain. It is recommended that work on obtaining the RD\&D permit be initiated by April 1995 to ensure its timely availability, if needed.

The actual sizing of the ion-exchange column tests has not been finalized. If the 10 - to $45-\mathrm{mL}$ range is accepted, one and possibly two of the three cells in the 325A complex would be available for other missions. The first alternative use of those cells is shown in the "First backup location" column.

\subsubsection{Filtration (TRU Monitor Testing)}

The recommended siting for the TRU monitor test was the 324 Building RCE cell complex, Cell D. As noted in the "Exceptions" column in Table 4-2, the first choice would have been the $325 \mathrm{~A}$ Building, Cell A, but that cell was identified for ion-exchange work. A second exception was the backup location identified as the WESF instead of the 324 SMF because a design for the WESF is available with some updating.

\subsubsection{Centrifugation and Filtration Testing}

The recommended siting for the centrifugation testing is the 222-S Laboratory Ce17. IF with a backup location in the 324 Building SMF-East Cel1. It is recommended that both filtration tests be set up in the same location because both could use most of the same equipment. As noted, larger scale flow testing will be delayed until mid-CY 1996 when the 25-L sampler system needs to become operational. As noted, the 324 SMF-East Cell is recommended for the filter testing. 
WHC-SD-WM-TA-160

Revision 0

\subsubsection{Ion-Exchange Case 1 Group 2 Testing}

This test uses 150-mL and 15-L samples. Placement of the work in the 222-S Laboratory, Cell lEI, will allow the small sample work to proceed on schedule. Initial 15-L samples may be provided by the $3-L$ sampler capability early in CY 1996. Later, 15-L samples will probabiy be retrieved with the 25-sampler and shipped in from the recommended 324 Building sampler service cell.

\subsubsection{Organic Defunctionalization Testing}

The recommended site for the organic defunctionalization testing is the 222-S Laboratory, Cell 11A, with Cell IA as a backup. This work will require $15100-\mathrm{mL}$ samples that can be readily supplied with the present sample infrastructure, and possibiy from the 222-s facility archived samples. One 10-L sample has been identified which could be supplied using the $3-L$ sampler capability that would be supported by the 222-S Laboratory.

\subsubsection{Settle/Decant Testing}

The recommended site for the settle/decant test work is the 3258 Building Shielded Analytical Laboratory cell. The recommended backup for this work was the 3047 Building, Cell A or D at ORNL: Needed sample sizes are five 2- to 4-L samples, which can be taken with the 3-L sampler and transhipped from the 222-S Laboratory to either location using the PAS-1 cask.

\subsubsection{Sludge Washing Tests}

The sludge washing tests, as noted in the tables in Appendix $B$, address 12 issues and are therefore more extensive than most of the technologies. The site evaluations rated 222-S Laboratory Cell $1 \mathrm{~A}$ as best suited for this work with the LANL Wing 9 facility rated slightly lower, but highly qualified. The LANL does have some needed laboratory equipment (ES-MS) not available at other sites except PNL. While this analys is was being developed and in the interests of meeting March, July, and September information need dates identified by the A-E, PNL's Office of Technology Development placed this work with LANL. The evaluation team fully supports that move and has concurred by listing LANL Wing 9 as its recommended location with the 222-S Laboratory, Cell IA as the backup.

\subsection{SUMMATION}

The scheduled test information need dates that have been identified by the IPM Project A-E require prompt commitment of facilities, staff, and funding to enable these test programs to move ahead at the needed pace. The activities required include preparation of detailed test plans based on this work, development of multiple sample retrieval and handling capabilities, facilities modifications to support sample receiving and test effluent management, design and fabrication of a wide range of test apparatus, 
extensive permitting reviews, preparation of an RD\&D permit and safety reviews, and aggressive performance of the tests.

The 324 Building SMF-South Cell has 11 window work stations that would be appropriate for other hot test work (e.g., enhanced sludge washing) if the inner cell partitions are removed and a shielded and encased transfer 1 ine is installed to the cell from the truck lock where a connection courd be made to the LR-56 transporter for waste and effluent transfers.

Although the cell is capable of personnel entry, it will take an estimated 6 to 8 months to clean it out. The cell 7 ighting and incell manipulators have been designed on the basis of personnel entry for repairs. That hardware will need modification for remote maintenance if the need arises to use the cell. A reassessment of the need for this cell should be performed when the test documentation is complete and the space requirements more clearly defined.

Section 5.0 provides a detajled action item 7 ist of recommendations for implementing this work. 
WHC-SD-WM-TA-160

Revision 0

This page intentionally left blank. 
WHC-SD-WM-TA-160

Revision 0

\subsection{RECOMMENDATIONS}

This section provides an action item list of recommendations to implement the findings and conclusions of the hot testing site evaluation team.

\subsection{HOT CELL FACILITIES}

- The hot cells recommended (Table 4-2) for the test work identified in this document should be committed and reserved solely for this effort.

While the study team was assured that the cells identified in this report were available for these missions, the team is aware that design work has been started for other applications of one cell. Firm commitments of these cells to the recommendations must be requested immediately and adhered to for the time it takes to make the cells operational for these test missions.

- A coordination team composed of Tank Farms Operations and Maintenance staff, test engineering staff, and IPM Project staff must be established and fully supported by their respective organizations to coordinate the design of the retrieval and transport systems and do the detailed planning required to enable the system operation when the equipment is available.

- An early assessment by the coordination team is needed to identify needed tank farm hardware (pumps, jumpers, etc.) that may require procurement and installation to support an October 1996 testing start date. This assessment should be followed by a general appraisal of requirements including staffing to ensure the success of the program.

- Cell cleanout and refurbishment now in progress in the $325 \mathrm{~A}$ complex should be complete by the first quarter of CY 1996. Design and installation of shielded and encased sample feed/effluent lines between the cells and the truck lock, and design and instaliation of sample and effluent tankage in the cells, should be complete by mid-CY 1996. Hot startup is planned for October 1996.

- Cleanout of the 324 Building RCE Cell D should be initiated. Cell C must be available for $25-L$ sampler servicing equipment installation by March 1996 and hot application by July 1996.

Cell $D$ should be ready for the TRU monitor installation in mid-CY 1996 and hot operation the last quarter of CY 1996. A means to transfer up to 4,000 L of high-activity waste from an LR-56 transporter in the truck lock to/from the cell will be required.

- Cleanout of the 324 SMF-East cell and upgrade of its lighting, master/slave manipulators, and crane for remote maintenance should be initiated for completion by May 1996. A shielded and encased waste transfer line is needed between the cell and the truck lock for transfer of five 100-L samples from the LR-56 transporter. 
WHC-SD-WM-TA- 160

Revision 0

- Requirements need to be developed by the end of February 1995 for safely field loading the LR-56 liquid waste transporter. Design and construction of facilities/equipment to enabie start of large-volume waste transfers are needed by October 1996.

\subsection{PERMITTING AND SAFETY}

- Preparation of an RD\&D permit for ion-exchange Case 2 testing in the 325A facility must be started by April 1995 to support hot testing by October 1996 should the larger scale testing be needed.

- The WHC Safety and Quality Assurance organizations must be intimately involved in developing the requirements and designs for the LR-56 loading/unloading facilities, and the 3 - and $25-L$ sampling systems to ensure ontime availability of those systems.

\subsection{RETRIEYAL EQUIPMENT, $<3$ L}

- An aggressive effort is needed to obtain the commercially available 500-mL sampler and locate casks capable of transferring the sampler to the 222-S Laboratory for servicing. A cell at the 222-S Laboratory must be identified for servicing and transhipment of samples to other site locations. The operational need date is July 1995 to support the aggressive CY 1995 multi-liter sampling plan.

- A similar effort is needed to develop the 3-L sample capability and servicing capability in the 222-S Laboratory, locate usable transfer casks, and provide and train operating staff. The operational need date is January 1996 or earlier.

\subsection{RETRIEYAL EQUIPMENT, $25 \mathrm{~L}$}

- A systems analysis of the 25-L sampler is needed by the end of March 1995 to provide a basis for interim and longer term development of this retrieval system.

- An operational system, including sampler, tank riser interface, means of insertion/removal/transfer to a cask, transfer cask and incell sampler servicing equipment, safety and operating procedures, and trained operating staff is needed by July 1996. Packaging design criteria have been prepared for the transfer cask.

\subsection{RETRIEVAL EQUIPMNENT, $100 \mathrm{~L}$ TO $4000 \mathrm{~L}$}

- A conceptual design study and safety analysis of a portable load/unioad capability for use at the tank farms is needed to define the requirments of this capability when used on a repetitive basis. 
WHC-SD-WM-TA-160

Revision 0

This design study and analysis are needed by Aprii, 1995 to support the development schedule for this capability.

- The 100 to 4000 L capability is based on utilizing a 4000 liter shielded transporter vehicle currently being procured by Waste Tank Plant Engineering as a means of emergency removal of liquids from a leaking single shell tank. It's pretreatment test support mission will be retrieval and transportation of a number of supernatant samples in the 100 to $500 \mathrm{~L}$ range and return of test effiuents to the tank farms. If required by future test plans, it would also provide the capability to handle larger samples.

- Infrastructure development to enable use of the transporter vehicle will include the portable hardware to enable field loading and unloading of the transporter at a tank farm, and fixed unload/reload capability and sample storage at the hot test facilites ( 324 and 325 Buildings) serviced by this equipment.

\subsection{TEST PLANNING}

- Individual test plans defining cold and hot testing are required for each of 49 issues that comprise the twe lve test groups identified in this report. As noted in Section 3.0, the test groups are groupings of individual or related issues for testing purposes that have common requirements that can be shared by the group to reduce overall testing cost and/or schedules. All plans should be available by the end of March 1995 to support test and facility design modification work and permit application preparation.

- Close involvement of the WHC Quality Assurance organization is needed to ensure that the data quality received from these tests are suitable for facility design and eventual qualification. 
WHC-SD-WM-TA-160

Revision 0

This page intentionally left blank.

5-4 
WHC-SD-WM-TA-160

Revision 0

\subsection{REFERENCES}

10 CFR 830, "Nuclear Safety Management," Code of Federal Regulations, as amended.

Clemen, R. T., 1991, Making Hard Decisions: An Introduction To Decision Analysis, Wadsworth Publishing Company, Belmont, California.

DOE, 1986, Safety analysis and Review System, DOE Order 5481.1B, U.S. Department of Energy, Washington, D.C.

DOE, 1992a, Nuclear Safety Analysis Reports, DOE Order 5480.23, U.S. Department of Energy, Washington, D.C.

DOE, 1992b, Hazard Categorization and Accident Analysis Techniques for Compliance with DOE Order 5480.23, Nuclear Safety Analysis Reports, DOE-STD-1027-92, U.S. Department of Energy, Washington, D.C.

Ecology, EPA, and DOE, 1994, Hanford Federal Facility Agreement and Consent Order, as amended, Washington State Department of Ecology,

U.S. Environmental Protection Agency, and U.S. Department of Energy, Olympia, Washington.

Howden, G. F., 1993, Pilot-Plant Hot Test Facility Siting Study, WHC-SD-WM-TA-143, Westinghouse Hanford Company, Richland, Washington.

Howden, G. F., D. E. Place, W. J. Powell, and M. Bullock, 1994, Tank Waste Remediation System Tank Waste Pretreatment and Vitrification Process Development Testing Requirements Assessment, WHC-SD-WM-TA-156, Rev. 0, Westinghouse Hanford Company, Richland, Washington.

Keeney, R. L., 1992, Value Focused Thinking: A Path to Creative Decision Making, Harvard University Press, Cambridge, Massachusetts.

National Environmental Policy Act of 1969, 42 USC 4321, et seq.

Place, D., 1994, personal communications.

Reddick, G. W., 1994, Testing and Development Strategy For the Tank Waste Remediation System, WHC-SD-WM-SP-006, Rev. 0, Westinghouse Hanford Company, Richland, Washington.

Resource Conservation and Recovery Act of 1976, 42 USC 6901, et seq.

Reynolds, B. A., 1994a, Hanford Tank Waste Remediation Systems (TWRS) Waste Pretreatment Program Test Requirements Strategy and Issues, PNL TWRSPP-94-096, Pacific Northwest Laboratory, Richland, Washington.

Reynolds, B. A., 1994b, Pretreatment Testing Support Facilities: Preliminary Functions and Requirements, PNL TWRSPP-94-109, Pacific Northwest Laboratory, Richiand, Washington. 
WHC-SD-WM-TA-160

Revision 0

Reynolds, B. A., 1994c, Pretreatment Testing Capability Assessment

Methodology, PNL TWRSPP-94-110, Pacific Northwest Laboratory, Richiand, Washington.

Stroup, C. R., 1994, "Meeting with States on Transportation of Hanford Tank Samples," E-Mail Memo, December 1, Westinghouse Hanford Company,

Richland, Washington (see Appendix G for a copy). 
WHC-SD-WM-TA-160

Revision 0

\title{
7.0 GLOSSARY
}

\author{
ABBREVIATIONS AND ACRONYMS \\ ANL Argonne National Laboratory \\ CST crystalline silicotanate \\ CX categorical exclusion \\ FY fiscal year \\ INEL Idaho National Engineering Laboratory \\ LANL LOS Alamos National Laboratory \\ LITCO Lockheed Idaho Technology Company \\ NEPA National Environmental Policy Act of 1969 \\ ORNL Oak Ridge National Laboratory \\ OSDT Oregon State Department of Transportation \\ PNL Pacific Northwest Laboratory \\ PUREX Plutonium Uranium Extraction \\ RCE radiochemical engineering \\ RCRA Resource Conservation and Recovery Act of 1976 \\ RD\&D research, development, and demonstration \\ SMF Shielded Materials Facility \\ SRL Savannah River Laboratory \\ SRP Savannah River Plant \\ TRU transuranic \\ TS treatability study \\ TWRS Tank Waste Remediation System \\ WESF Waste Encapsulation and Storage Facility \\ WHC Westinghouse Hanford Company
}


WHC-SD-WM-TA-160

Revision 0

This page intentionally left blank. 
WHC-SD-WM-TA- 160

Revision 0

APPENDIX A

TECHNICAL BASIS

$A-1$ 
WHC-SD-WM-TA-160

Revision 0

\section{CONTENTS}

AI TANK WASTE REMEDIATION SYSTEM PRETREATMENT PROGRAM TECHNICAL STRATEGY . . . . . . . . . . . . . . . . . . . . A-3

A2 ION-EXCHANGE TEST CELL SPACE ESTIMATE . . . . . . . . . . . . . A-9

A3 TESTING SAMPLE SIZE ESTIMATE . . . . . . . . . . . . . A-17

\section{LIST OF FIGURES}

A-1 Pretreatment Block Diagram . . . . . . . . . . . . . A-6

A-2 Ion-Exchange Test Cell Space Estimate . . . . . . . . . . A-11

\section{LIST OF TABLES}

A-1 Testing Sample Size Estimate . . . . . . . . . . . A-19 
WHC-SD-WM-TA- 160

Revision 0

APPENDIX AI

TANK WASTE REMEDIATION SYSTEM PRETREATMENT

PROGRAM TECHNICAL STRATEGY 
WHC-SD-WM-TA-160

Revision 0

This page intentionally left blank. 
Revision 0

APPENDIX A

TECHNICAL BASIS

\section{A1.0 TANK WASTE REMEDIATION SYSTEM PRETREATMENT PROGRAM TECHNICAL STRATEGY}

The pretreatment technical strategy was developed as part of the Tank Waste Remediation System rebaselining effort in fiscai year (FY) 1993, culminated in an agreed upon strategy in November and December 1993 and described in Gasper 1994. The technical strategy is in harmony with the fourth amendment to the Tri-Party Agreement and is graphically illustrated on Figure $A-1$, taken from that document. This strategy provides the following functional descriptions for the mission.

- Prepare tank wastes to provide suitable feeds to low-level waste (LLW) pretreatment and high-level waste (HLW) pretreatment processes.

- Pretreat prepared supernate to produce feed for LLW immobilization. (This function includes removal of radionuclides and product concentration to remove bulk chemicals including water.)

- Condition HLW sludges and transuranic tank waste sludges for immobilization and eventual disposal in a designated geological repository.

- Place separated radionuclides into a form that may be blended with pretreated HLW solids to become feed for HLW immobilization. follows.

Key assumptions of the pretreatment technical strategy are summarized as

- Current tank waste characterization information is sufficient for planning purposes.

- Sludge washing, leaching, and blending will be adequate to achieve an acceptably low HLW volume and composition. Acid dissolution and advanced separations are not required. Organic destruction is not required for organic content reduction.

- Sludge washing, leaching (including enhanced sludge washing) will be performed within the double-shell tanks.

- Waste witl be blended to increase waste loading in the LLW and HLW forms.

- The LLW feed stream to the LLW immobilization facility will be acceptable if the ${ }^{137} \mathrm{Cs}$ is reduced to $1 \mathrm{Ci} / \mathrm{m}^{3}$ in the resulting $\mathrm{LLW}$ glass and ${ }^{90} \mathrm{Sr}$ is removed when necessary. 
WHC-SD-WM-TA- 160

Revision 0

Figure A-1. Pretreatment Block Diagram.
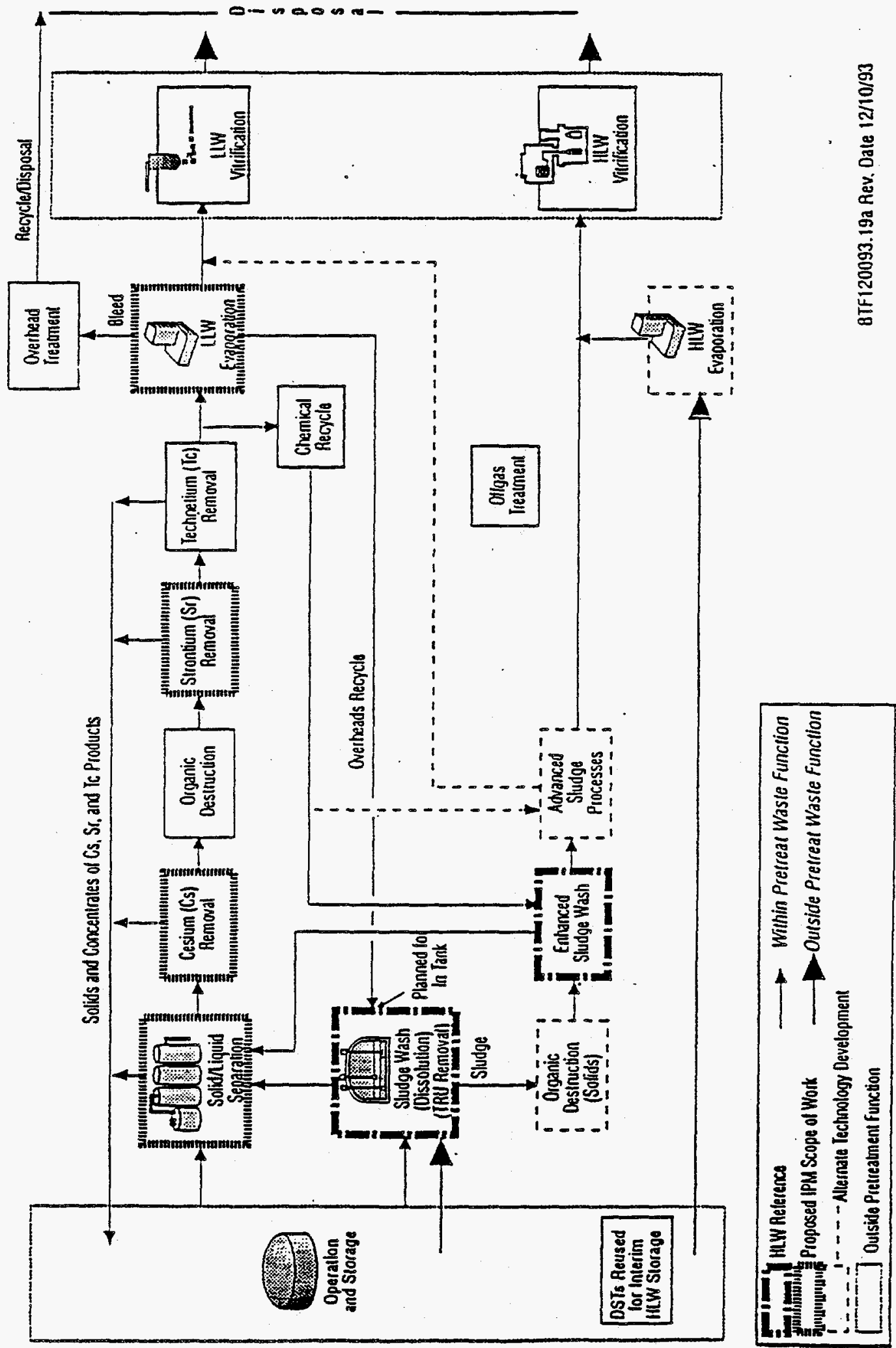
- Evaporators in the pretreatment facility will perform the volume reduction function.

The following are current baseline assumptions being used in the conceptual design of the pretreatment facility.

- Primary HLW/LLW separation will be carried out in existing underground waste tanks.

- The supernate $L L W$ feed stream will require separation of fine solids before other pretreatment functions.

- Removal of cesium and strontium are the primary pretreatment functions. Technetium removal may be required and for planning purposes is required.

- Organic destruction in support of radionuclide removal is assumed for planning purposes.

- Pretreatment product stream volume reduction is required but does not require development effort. 
WHC-SD-WM-TA-160

Revision 0

This page intentionally left blank.

A-8 
WHC-SD-WM-TA-160

Revision 0

APPENDIX A2

ION-EXCHANGE TEST CELL SPACE ESTIMATE 
WHC-SD-WM-TA-160

Revision 0

This page intentionally left blank. 
Figure A-2. Ion-Exchange Test Cell Space Estimate. (6 sheets)

DON'T SAY IT -- Write It!

To: BA Reynolds
Date: October 31, 1994

From: OE Kurath

Subject: Space Requirements for lX hot testing

I've attached some information reflecting a range of IX hot testing requirements. The space requirements are a strong function of the bed volume so I have presentad some ranges. My recommendation is to go as small as possible to reduce cost and waste requirements.

Summary Table - Hot Call Space Requirements, $\mathrm{ft}^{2}$

\begin{tabular}{|l|l|l|l|}
\hline & $\begin{array}{l}R-F=12 \mathrm{~mL} \\
C S-100=42 \mathrm{~mL}\end{array}$ & $\begin{array}{l}100 \mathrm{~mL} \\
\text { Coiumns }\end{array}$ & $\begin{array}{l}200 \mathrm{~mL} \\
\text { columns }\end{array}$ \\
\hline $\begin{array}{l}R-F, C S-100 \text { regenerable } \\
\text { system }\end{array}$ & 15 & 25 & 30 \\
\hline $\begin{array}{l}\text { R-F, CS-100 regenerable } \\
\text { system - tanks for CST } \\
\text { system }\end{array}$ & 25 & 70 & 95 \\
\hline
\end{tabular}

Nota: The $100 \mathrm{~mL} R-F, C S-100$ regenerable system can inandle $10 \mathrm{~mL}$ columns of CST (100 $\mathrm{nL}$ column system) or $20 \mathrm{~mL}$ columns of CST (200 $\mathrm{mL}$ column system).

Assumptions

1) I Feed tank and I LLW receiver tanks - $30 \mathrm{~L}$ (small column size), 200 b Feed tank (100 mL columns for R-F and CS-100, $10 \mathrm{~mL}$ column for CST's), 400 L (200 $\mathrm{mL}$ column for R-F, CS-100, $20 \mathrm{~mL}$ Column for CST's), $1800 \mathrm{~L}$ (CST's, $100 \mathrm{~mL}$ columns), 3200 (CST's $200 \mathrm{~mL}$ columns). Column rinse, wash and regeneration steps contribute minimal volume to LLA receiver tank. The tanks ara sized to allow one full loading $(1.5 \lambda)$ bed volumes of feed for both the $R-F$ and CS-100 resins pius head space. CST's would be a separate run because of the large volume requirements.

2) I heat exchanger for temperature control of feed tank and columns.

3) I eluant receiver tank - $50 \mathrm{~L}$. Assume 40 bed volumes of eluant per elution, the volume of eluant is $4 \mathrm{~L}$ per elution (100 $\mathrm{mL}$ column) and $8 \mathrm{~L}$ per $200 \mathrm{~mL}$ column pius space needed for neutralization of acidic eluant. $50 \mathrm{~L}$ is probably bigger than needed. 
WHC-SD-WM-TA-160

Revision 0

Figure A-2. Ion-Exchange Test Ce11 Space Estimate. (6 sheets)

4) 3 pumps

5) The feed tank size for CST's is based on SNL's sample request of $80 \mathrm{~L}$ for in-tank waste ( $10 \mathrm{~mL}$ column), waste is assumed (ny assumption) to be $10 \mathrm{M}$ sodium and difuted to 5 in sodium).

6) Waste voiume for [5T's is basad on an assumed $A$ of 1000 .

Note: nitric acid, sodium hydroxide, water are assumed to be added diractly to the process from the nonradioactive side of the hot call. In cell chemical supply ieed tanks are not required.

Table 2 Minimum Bed Volume - Casium In

\begin{tabular}{|l|l|l|}
\hline & R.F resin & $C S-100$ \\
\hline Minimum & $0.8 \mathrm{~mL}$ & $5.4 \mathrm{~mL}$ \\
\hline $\begin{array}{l}\text { Repilicate } 200 \mathrm{~mL} \\
\text { columns }\end{array}$ & $12 \mathrm{~mL}$ & $42 \mathrm{~mL}$ \\
\hline
\end{tabular}

E54-3000-101 (10/89) 
Figure A-2. Ion-Exchange Test Cell Space Estimate. (6 sheets)

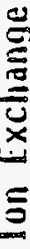

\begin{tabular}{|c|c|c|c|c|c|c|c|c|c|c|c|}
\hline 蒡 & 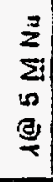 & 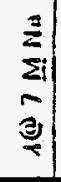 & 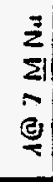 & 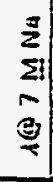 & 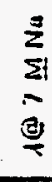 & 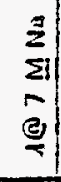 & 至 & 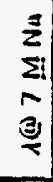 & 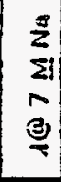 & 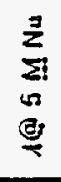 & 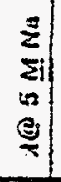 \\
\hline
\end{tabular}



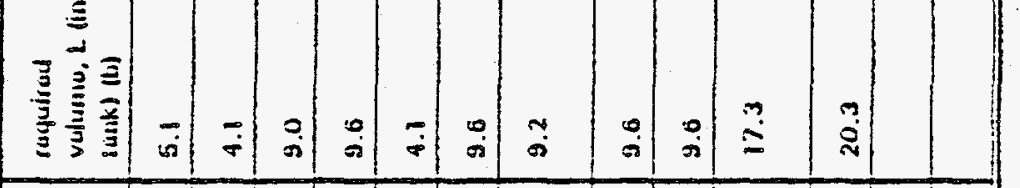

|

- 9 年

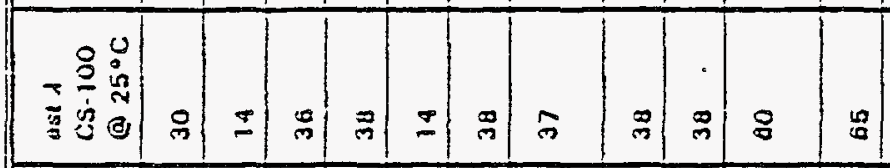

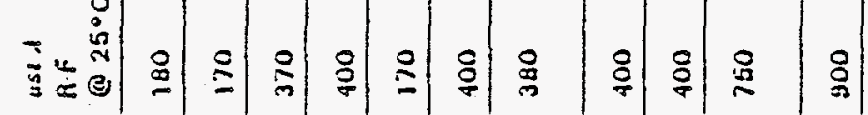

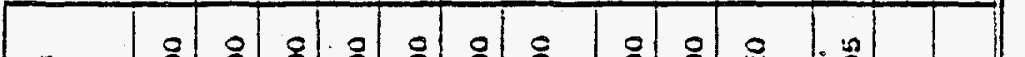

$气$

¿.

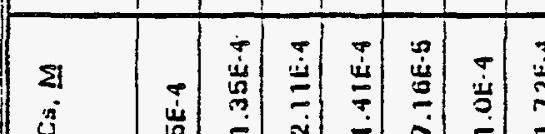

$i^{3}$

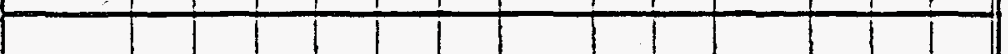

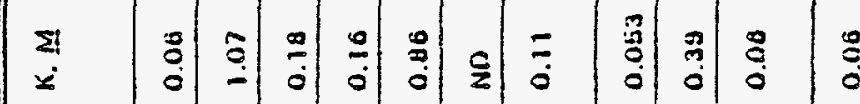

\begin{tabular}{|c|c|c|c|c|c|c|c|c|c|c|c|}
\hline $\begin{array}{l}\Sigma \\
i \\
\Sigma\end{array}$ & $\Omega$ & $=1$ & $\because$ & $\simeq$ & $\begin{array}{l}0 \\
: \\
:\end{array}$ & $\frac{2}{3}$ & $\stackrel{\check{I}}{\Xi}$ & 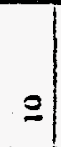 & $\stackrel{0}{\dot{I}}$ & $\therefore$ & ம) \\
\hline 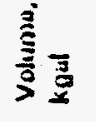 & $\frac{9}{\sigma}$ & $\bar{\Xi}$ & $\stackrel{9}{9}$ & $\stackrel{\mathbb{N}}{=}$ & $\overline{\boldsymbol{x}}$ & 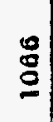 & $\stackrel{n}{5}$ & $\stackrel{0}{0}$ & 喜 & 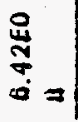 & $:$ \\
\hline$\underline{E}$ & 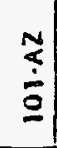 & $\begin{array}{l}3 \\
\vdots \\
\vdots \\
\vdots\end{array}$ & $\begin{array}{l}\vec{z} \\
\dot{a} \\
\vdots \\
\vdots\end{array}$ & $\begin{array}{l}7 \\
\vdots \\
\vdots \\
\vdots\end{array}$ & $\begin{array}{l}\frac{a}{a} \\
\dot{a} \\
\stackrel{a}{a}\end{array}$ & $\begin{array}{l}\tilde{z} \\
\dot{a} \\
\underline{\theta}\end{array}$ & 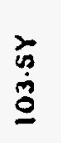 & $\begin{array}{l}z \\
\dot{u} \\
\dot{u} \\
\underline{3}\end{array}$ & $\begin{array}{c}z \\
\dot{a} \\
\vdots \\
0\end{array}$ & : & $:$ \\
\hline$\xi$ & 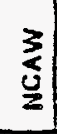 & & $\begin{array}{l}\text { 离 } \\
\vdots \\
0\end{array}$ & 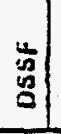 & 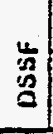 & $\vec{v}$ & $\ddot{8}$ & $\ddot{s}$ & 量 & 勇虽 & $\begin{array}{l}n \\
0 \\
\vdots \\
\vdots\end{array}$ \\
\hline
\end{tabular}

A-13

菑

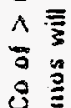

S

$\stackrel{5}{=} \frac{3}{3}$

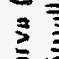

赵

言立

产紊

突

듬

豆

롤

旅

5

咅 8

亭

远

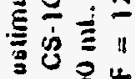

농

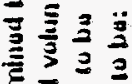

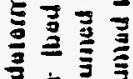

흘

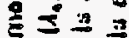

흘를

$2=\frac{3}{3}$

言总菏 
WHC-SD-WM-TA- 160

Revision 0

Figure A-2. Ion-Exchange Test Cell Space Estimate. (6 sheets)

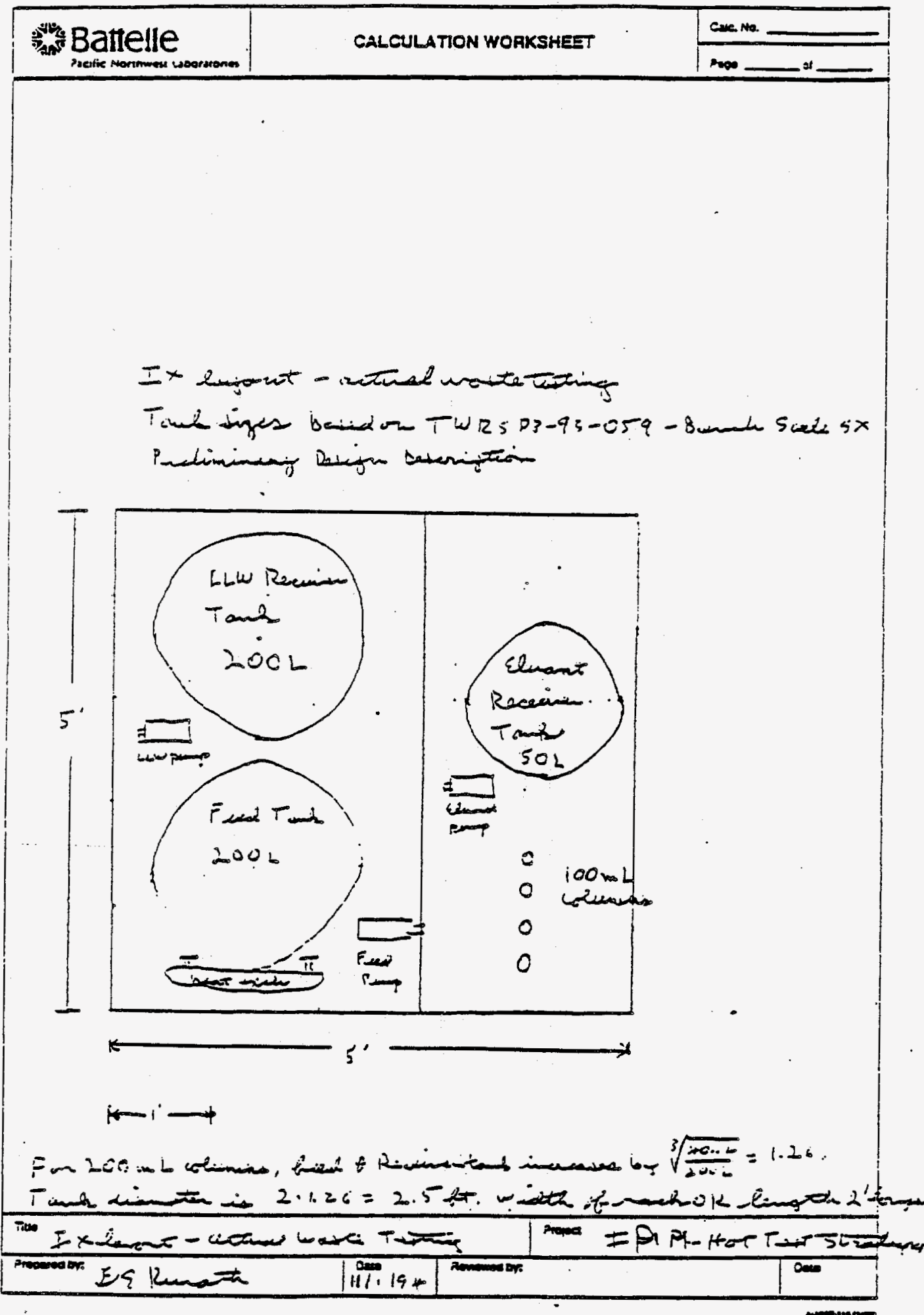


WHC-SD-WM-TA-160

Revision 0

Figure A-2. Ion-Exchange Test Cell Space Estimate. (6 sheets)

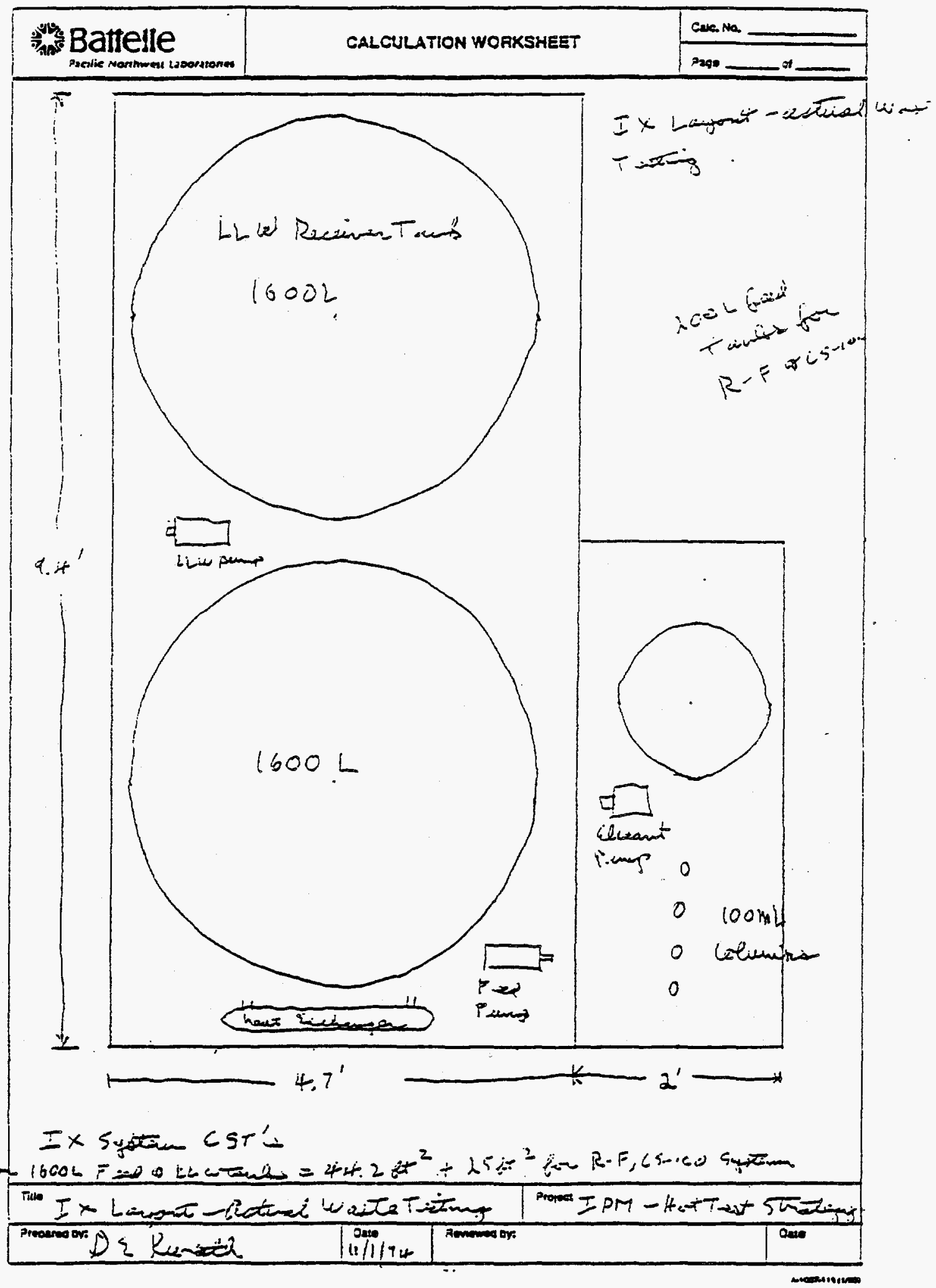


WHC-SD-WM-TA- 160

Revision 0

Figure A-2. Ion-Exchange Test Cell Space Estimate. (6. sheets)

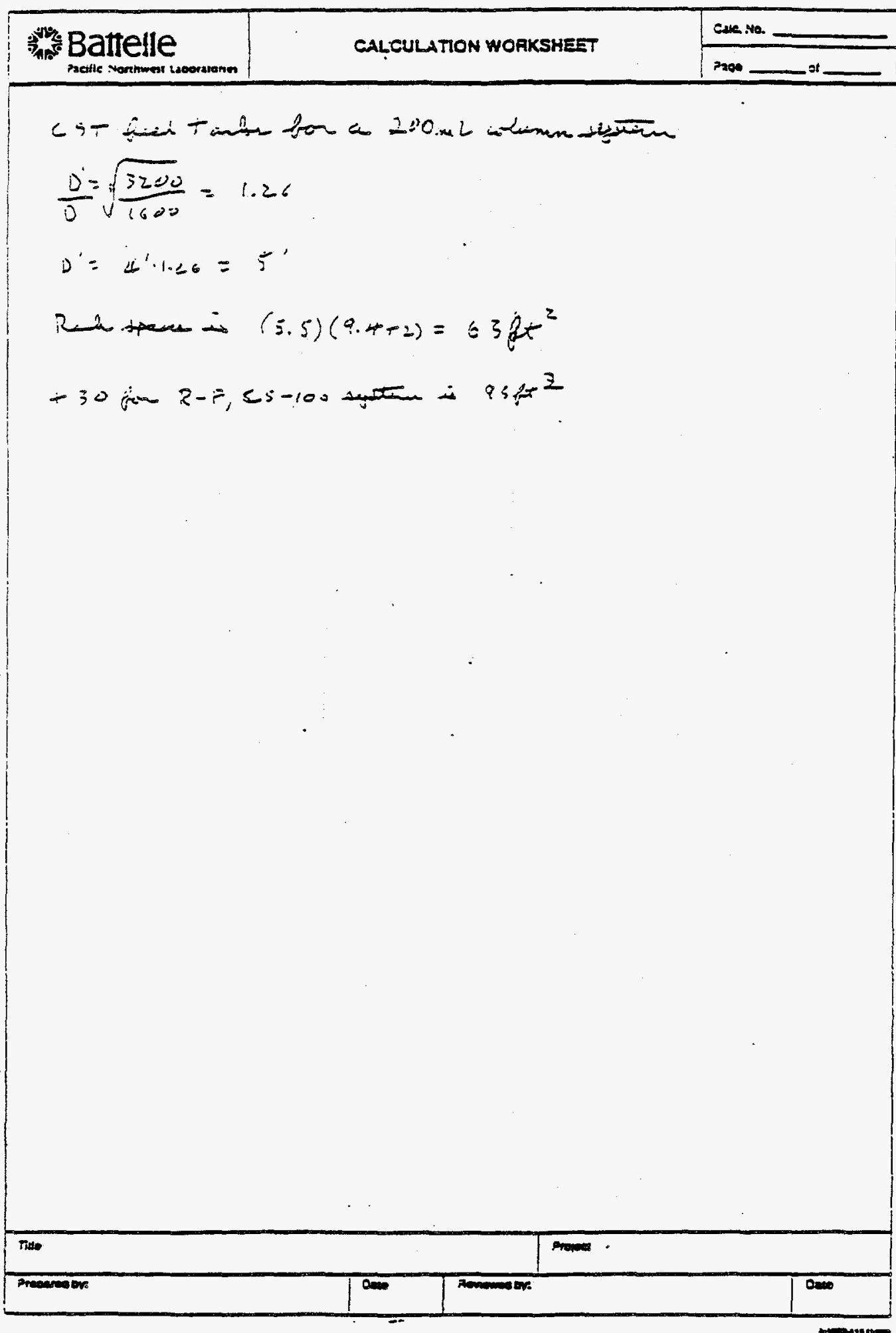

$A-16$ 
WHC-SD-WM-TA-160

Revision 0

APPENDIX A3

TESTING SAMPLE SIZE ESTIMATE

A-17 
WHC-SD-WM-TA- 160

Revision 0

This page intentionally left blank. 


$$
\begin{gathered}
\text { WHC-SD-WM-TA-160 } \\
\text { Revision } 0
\end{gathered}
$$

Table A-1. Testing Sample Size Estimate. (2 sheets)

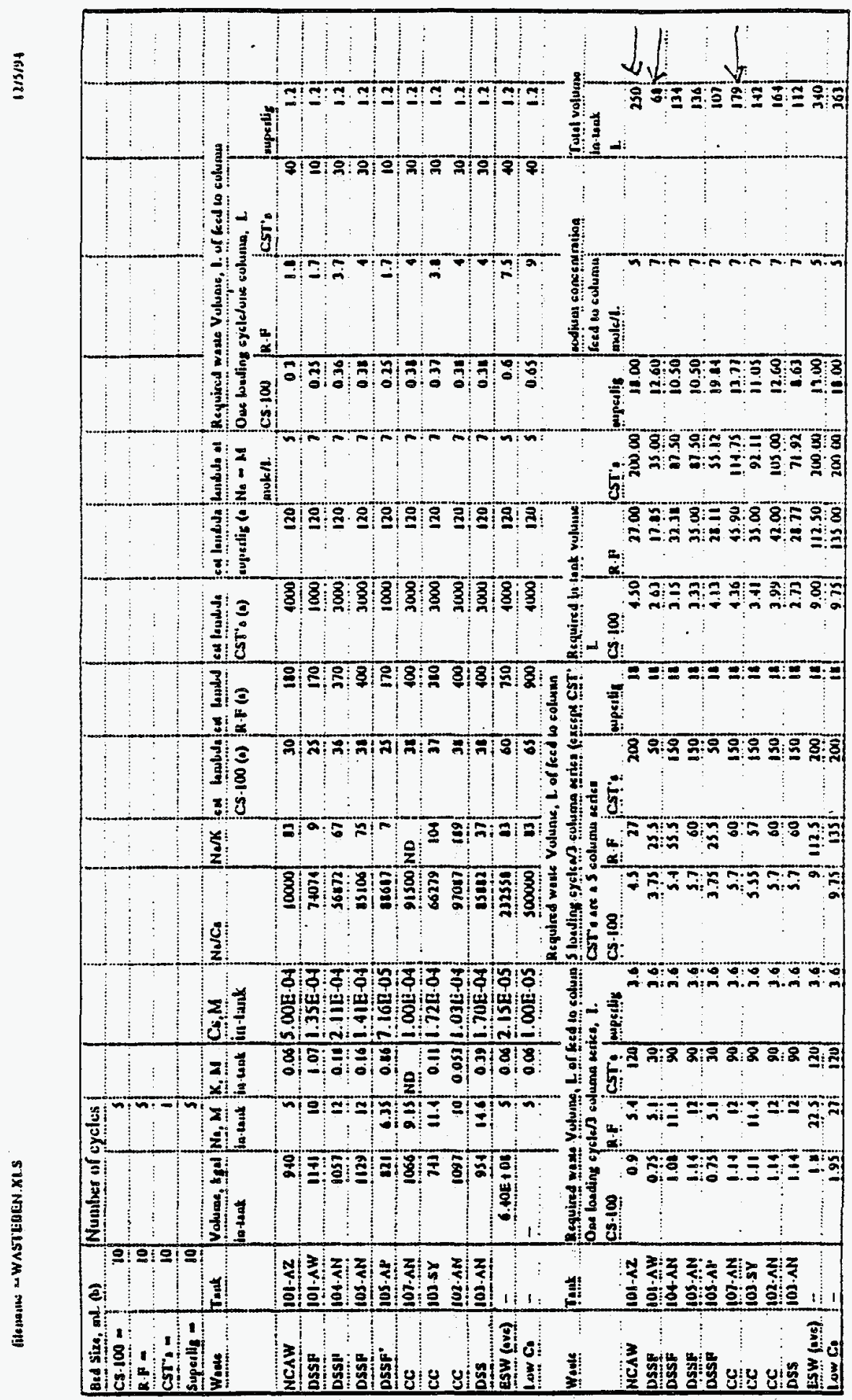


WHC-SD-WM-TA-160

Revision 0

\section{A4.0 REFERENCES}

Ecology, EPA, and DOE, 1994, Hanford Federal Facility Agreement and Consent Order, as amended, Washington State Department of Ecology,

U.S. Environmental Protection Agency, and U.S. Department of Energy, Olympia, Wastington.

Gasper, K. A., 1994, Hanford Tank Waste Remediation Systems (TWRS) Waste Pretreatment Program Strategy and Issues, WHC-SA-2140-FP, Westinghouse Hanford Company, Richland, Washington. 
WHC-SD-WM-TA- 160

Revision 0

This page intentionally left blank. 
WHC-SD-WM-TA-160

Revision 0

APPENDIX $B$

HOT TESTING ISSUE DEFINITIONS AND GROUPING

$B-1$ 
WHC-SD-WM-TA-160

Revision 0

\section{LIST OF TABLES}

B-1 Issue Group Definitions .................... B-3

B-2 Ion-Exchange 10- to 45-mL COL Case 1............. B-6

B-3 Ion-Exchange 200-mL COL Case 2.................. B-7

B-4 Sludge Wash ....................... . . B-8

B-5 Organic Destruction . . . . . . . . . . . . . . . . B-9

B-6 Settle/Decant ...................... B-10

B-7 Filtration ....................... . B-11

B-8 Centrifugation . . . . . . . . . . . . . . . . . . B-12 


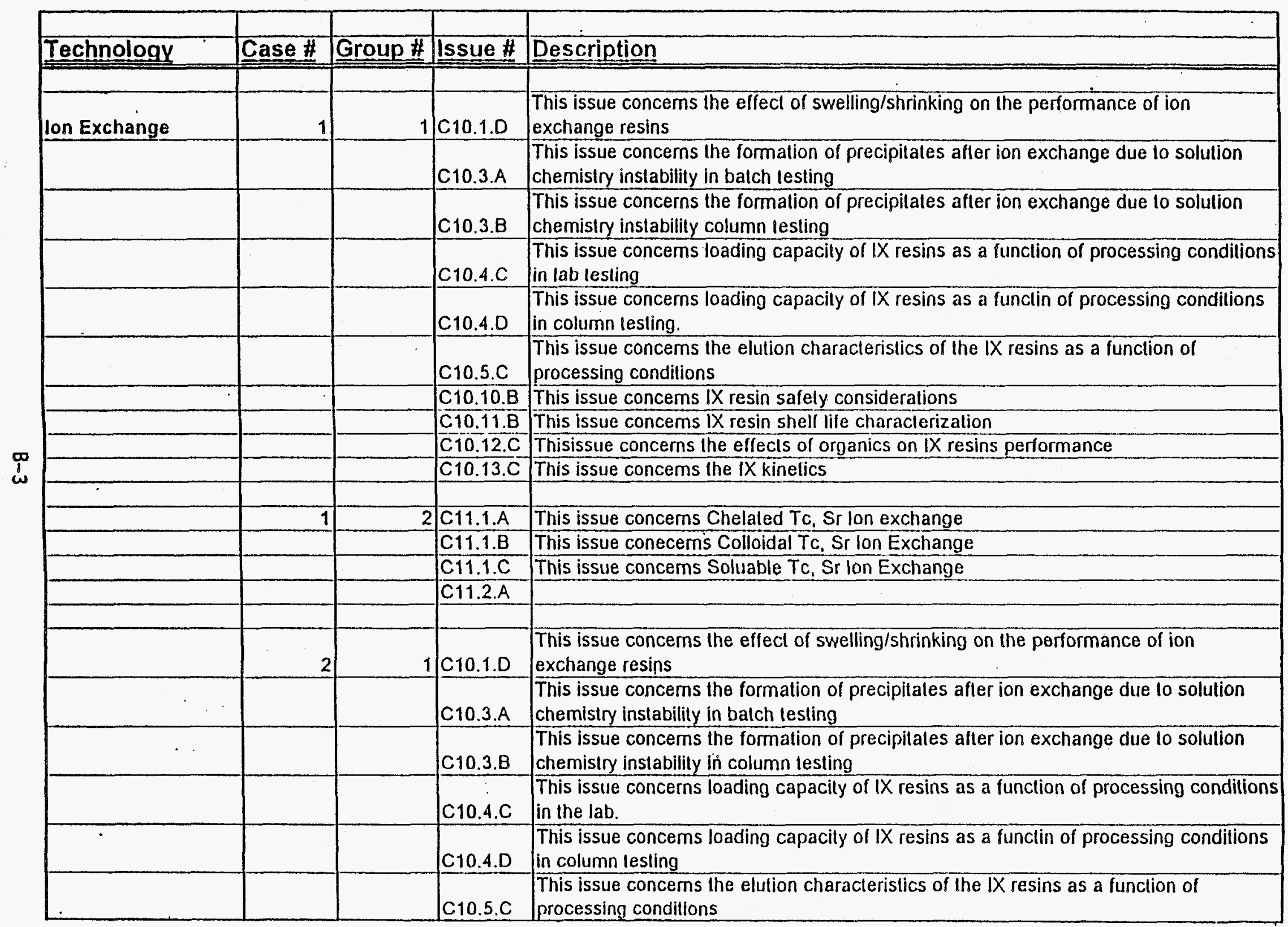




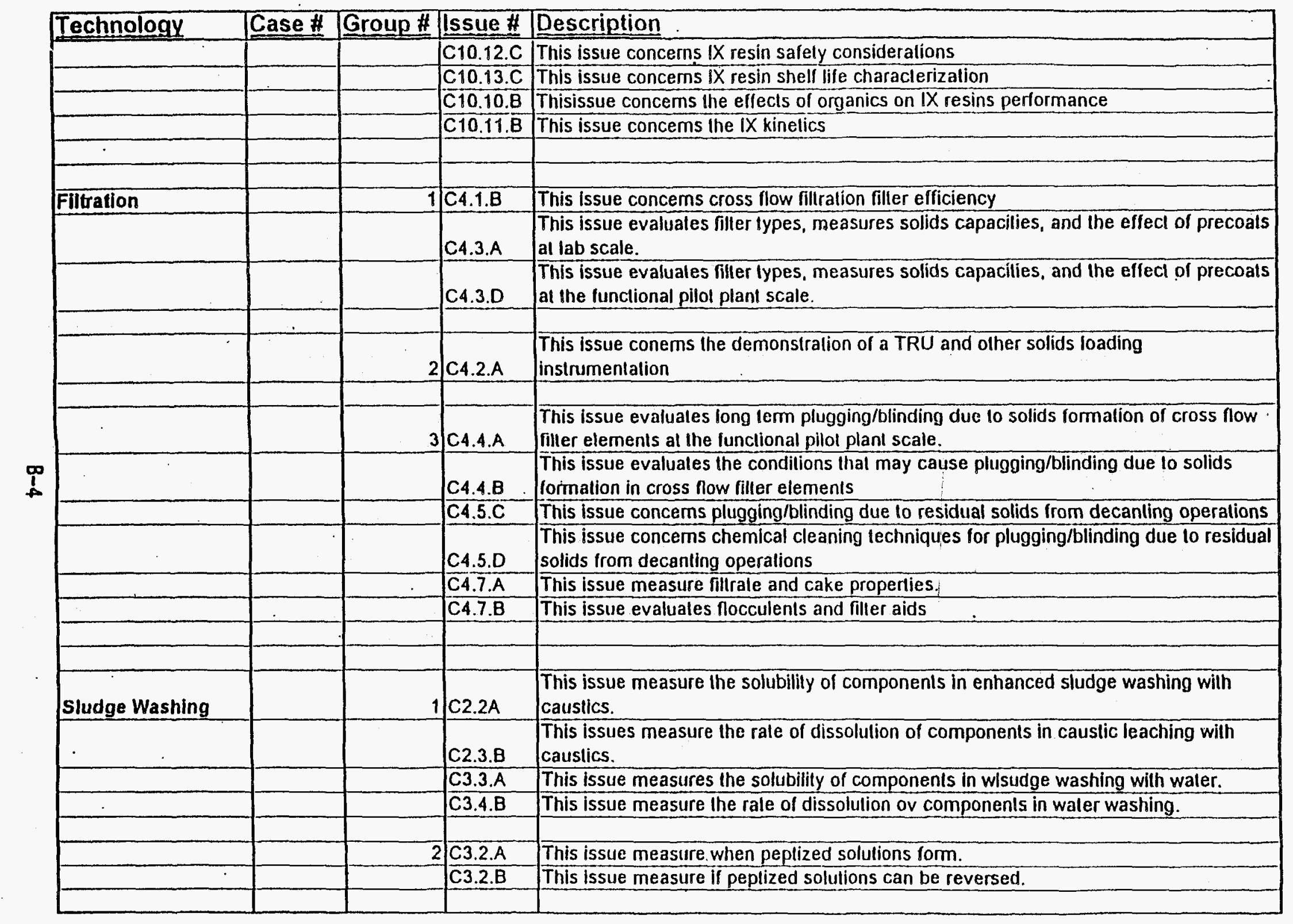




\begin{tabular}{|c|c|c|c|c|}
\hline Technology & Case \# & Group \# & Issue\# & Description \\
\hline & & & C11.3.A & $\begin{array}{l}\text { This issue measure the concentration of technetium and its valence states in tank } \\
\text { wastes. }\end{array}$ \\
\hline & & & & \\
\hline & & 4 & C11.5.A & This issue evaluate the form of $\mathrm{Sr}$ in the waste \\
\hline & & & $\mathrm{C} 11.5 . \mathrm{B}$ & This issue evaluate the Sr variablity in tank wastes. \\
\hline & & & C11.5.C & This issue evaluale a Sr removal by preciptation processes. \\
\hline & & & C11.5.D & This issue evaluate whether so removed by preciptalion process will re-dissolve. \\
\hline & & & C11.5.E & This issue evaluate processing paramelers for $S \mathrm{~s}$ removal by preciptation process \\
\hline & & & & \\
\hline \multirow[t]{3}{*}{ Centrifugation } & & 1 & $\overline{C 5.1 . A}$ & This issue measure the properties of cenlrifuge cake \\
\hline & & & C5.2.B & $\begin{array}{l}\text { This issue evaluales the influence of nocculents and addilives on centrifugation } \\
\text { performance }\end{array}$ \\
\hline & & & C5.3.B & This issue measure the performace of cenlrifuges. \\
\hline & & & & \\
\hline \multirow[t]{8}{*}{ Settling/Decanting } & & 1 & C1.1.A & This issue measure seflling rates of solids \\
\hline & & & C1.1.B & This issue evaluates setlling rate instrumentation \\
\hline & & & C1.2.A & This issue measures sellling rate dala. \\
\hline & & & C1.2.B & This issue characterizes the solids \\
\hline & & & & \\
\hline & & 2 & C1.3.A & This issue measure the radioaclivily as a funclionof particle size. \\
\hline & & & C1.4.A & This issue measure the changes to particle sizes following lank mixing. \\
\hline & & & & 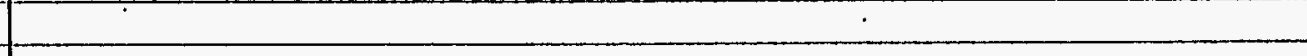 \\
\hline \multirow{3}{*}{ Organic Destruction } & & 1 & C7.1.A & This issue performs in-tank hydrolysis for organic destruclion \\
\hline & & & CB.10.C & This issue performs in-lank hydrolysis and determines changes to TRU/Sr partioning. \\
\hline & & & C8.10.D & THis issueperforms scaled-up in-tank hydrolysis for organic destruclion \\
\hline
\end{tabular}




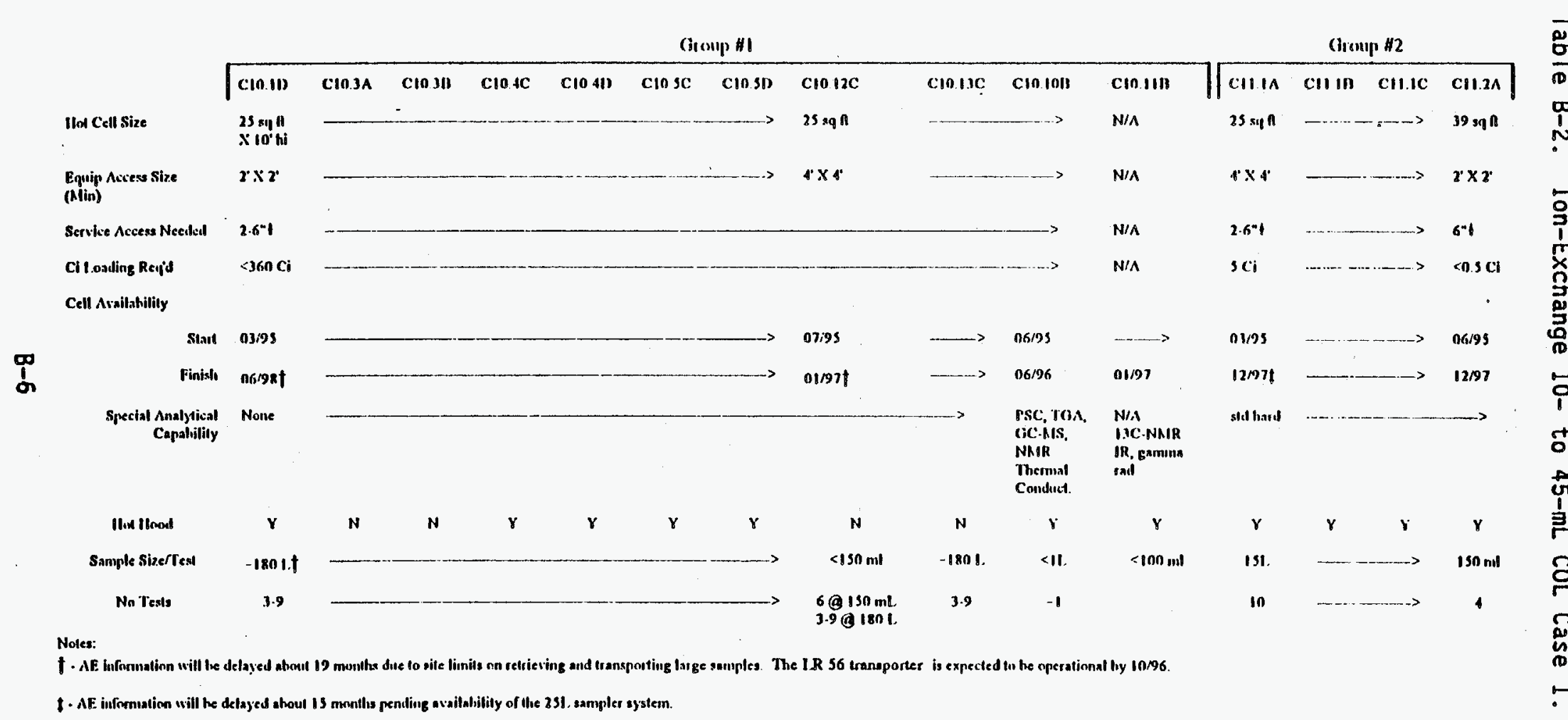

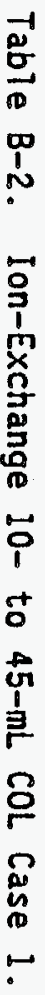


Table B-3. Ion-Exchange 200-mL COL Case 2.

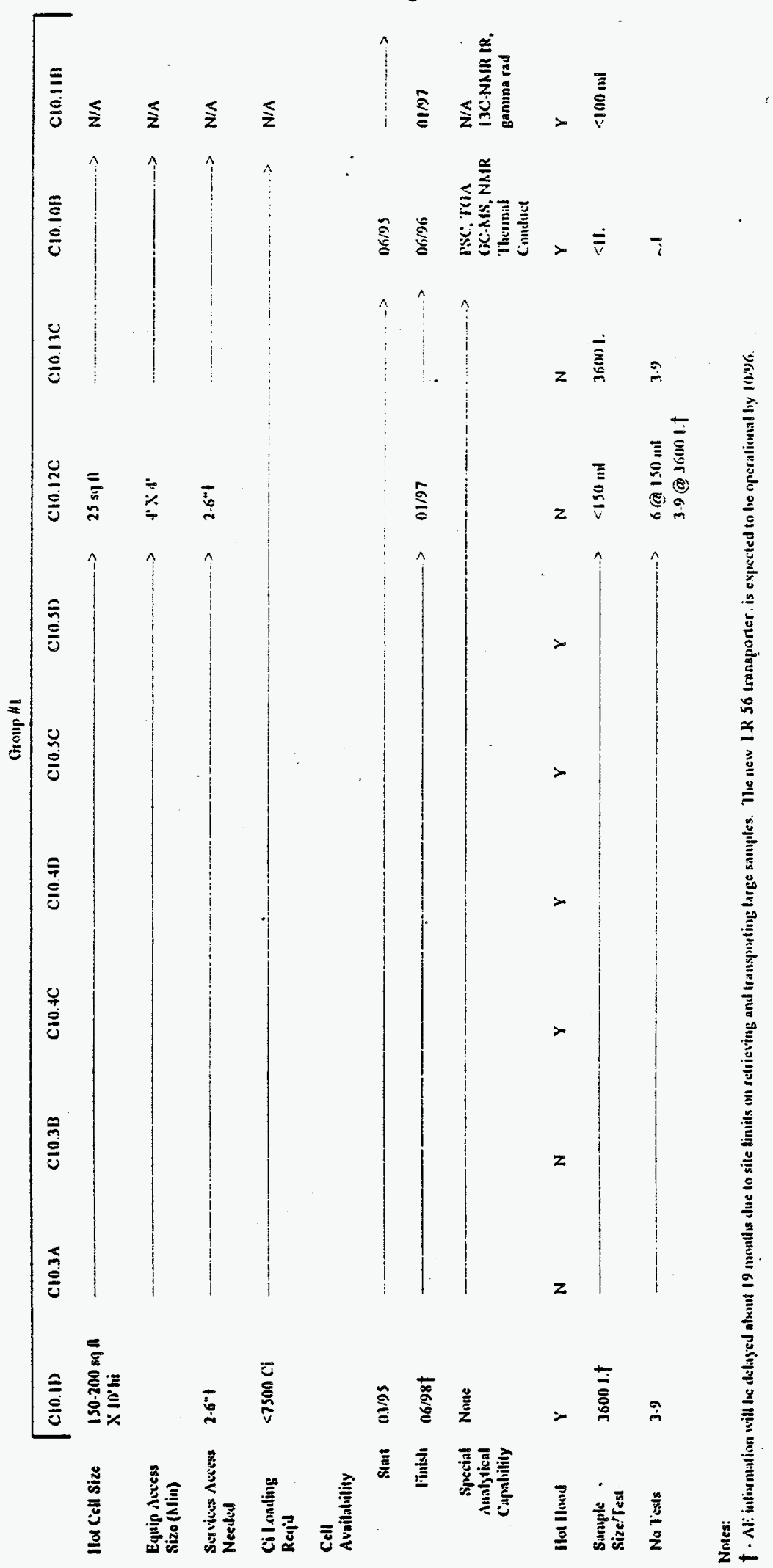




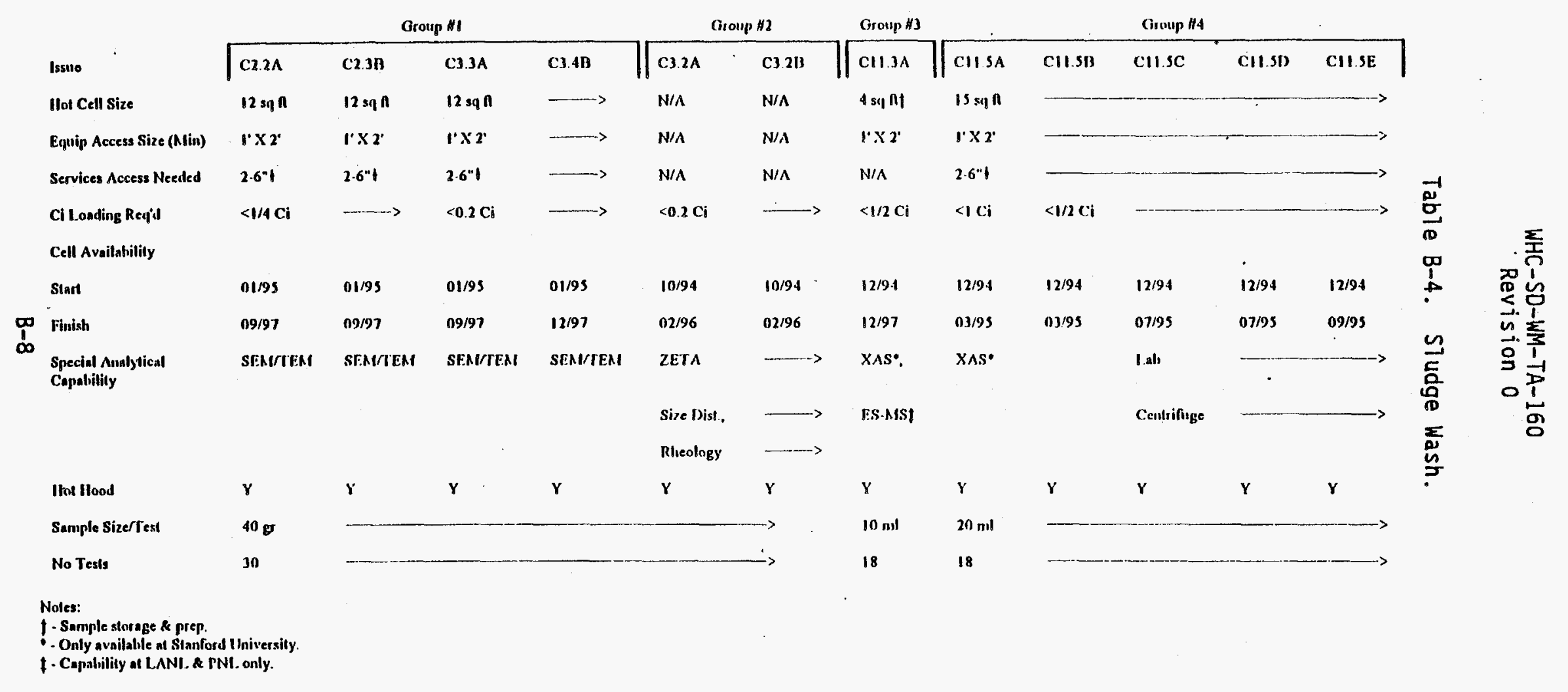


Table B-5. Organic Destruction.

Group \#1

Hot Ceil Size

C7.1A

C8.10C

CS.10D

9 sq $\mathrm{tt}$

12 sq ft

lo sq $\mathrm{ft}$

Equip. Access Size (Min)

$l^{\prime} \times 2^{\prime}$

$l^{\prime} \times 2^{\prime}$

$l^{\prime} \times 2^{\prime}$

Services Access Needed

$1-5^{\prime \prime}$

$2-5 \phi$

$2-6 !$

Ci Loading Req'd

$<5 \mathrm{Ci}$

$<1 \mathrm{Ci}$

$<10 \mathrm{Ci}$

Cell Avaiiability

$$
\text { Start }
$$

$10 / 94$

$04 / 95$

$06 / 96$

Finish

$09 / 95$

$12 / 96$

$03 / 97$

Special Analycical Capability

None

Hot Hood

$Y$

$Y\left(2^{\prime} X 7^{\prime}\right)$

$Y$

Sample Size/Test

1 @. $5 \mathrm{~L}$

$2-1 \mathrm{~L}$

$7 @ 0.11$

$100 \mathrm{ml}$

$10 \mathrm{~L}$

No Tests

8

7

1 
WHC-SD-WM-TA-160

Revision 0

Table B-6. Settle/Decant.

Group

\author{
Issue \\ Hot Cell. Size \\ Equip. Access Size (Miri) \\ Services decess Needed \\ Ci Loading Req'd.
}

Ceil Availability

\begin{tabular}{|c|c|c|}
\hline Cl.lA & CL.1B & C1.2B \\
\hline 36 sq $\mathrm{tt}^{\circ}$ & & N/A \\
\hline $2: X=$ & & W/A \\
\hline $2-5^{\prime \prime}$ & & N/A \\
\hline $12 \mathrm{Ci}$ & 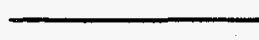 & N/A \\
\hline
\end{tabular}

Group $\approx 2$

CI.3A C1.+B
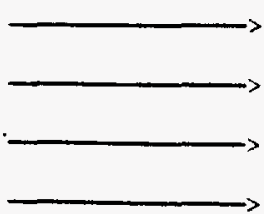

\section{in progress}

$06 / 94$

$01 / 97$

0495

$01 / 98 t$

$06 ; 98$

$06 ; 98$

$06 ; 95$

SEM

IEM

Size Dist

Rheology

$\begin{array}{llllll}Y & Y & Y & Y & Y & Y \\ 3 \rightarrow L & & \\ & \end{array}$

Notes:

- Preliminary test dath may be available by AE information need date of 06/95.

Tesing of 5 selected tank wastes would not be complete umil abour 09/96.

: - Function is hot lab work to characterize dip sampies taken at varying sages of in-tank serling to measure seuting progress. 
II -8

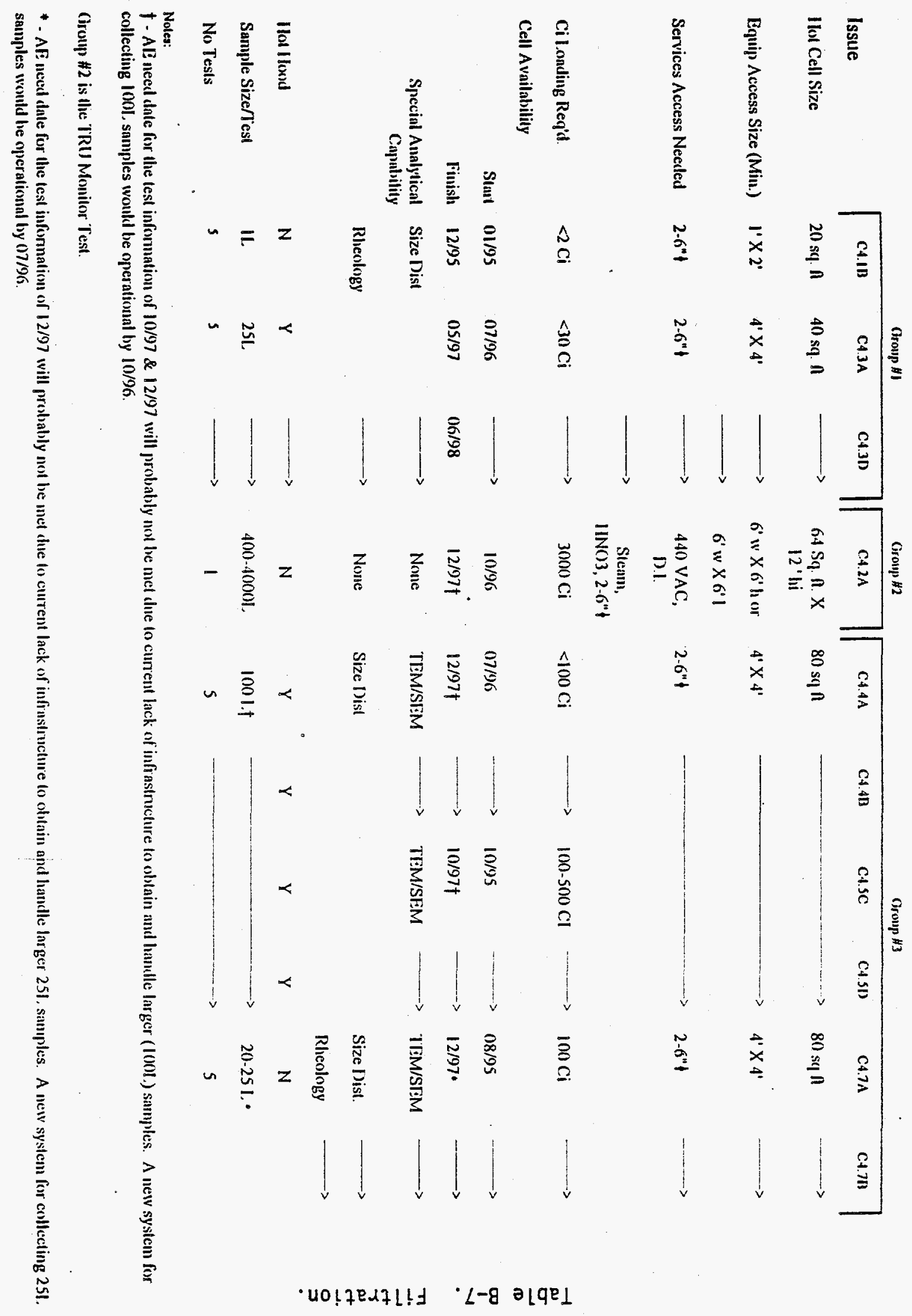


WHC-SD-WM-TA-160

Revision 0

Tabie B-8. Centrifugation.

Group \#1

Issue

Hor Cell Size

Equip. Access Size (Min)

Services Access Needed

Ci Loading Reg'd.

Ceil Availabiiity

Star
Finisis
Special Anaiyrica
Capabili

\section{Hot Hood}

Sample SizerTest

No Tests
CS.1A

N/A

N/A

N/A

$<3 \mathrm{Ci}$

$10 / 95$

$12 / 96$

TENSEM

Densities

Size Dist

Y

$100 \mathrm{mi}$

30

\section{C5.2B}

100 sq At

$4^{\prime} \times 4^{\prime}$

$2.5 \phi$

$<500 \mathrm{Ci}$

$01 / 96$

$12 / 96+$

IEMUSEM

Densivies

Size Dist

Rheoiogy

$Y$

100-500 LT

4
C5.jB
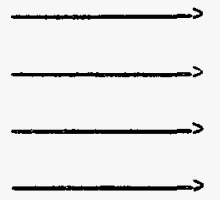

$10 / 95$

$03 / 98$

Notes:

+ AE information date shown will be delaved 19 months due to site limizs on retrieving \& transporing the specified test sample sizes. The new LR 56 transporter shouid be operavional by $10 / 96$ for the large tert sampies. 
WHC-SD-WM-TA-160

Revision 0

\section{APPENDIX C}

SAMPLE RETRIEVAL AND HANDLING EQUIPMENT

$$
c-1
$$


WHC-SD-WM-TA-160

Revision 0

\section{CONTENTS}

Cl 3- AND 25-L SAMPLER CONFIGURATION .................. . C-3

C2 $25-L$ SAMPLER TANK RISER HANDLING INTERFACES . . . . . . . . . . . $. \quad c-7$

C3 LR-56 SHIELDED LIQUID WASTE TRANSPORTER . . . . . . . . . . . . . c-11

C4 PAS-1 CASK ...................... . . . . . . . . . . .

\section{LIST OF FIGURES}

C-1 Savannah River Site 3- and 25-L Sludge Collector Concept . . . . . C-5

C-2 Mobile Waste Tank Riser 3- and 25-L Sampler Interface Concept . . . C-9

C-3 Savannah River Site 25-L Sampler Waste Tank Interface . . . . . . C-10

C-4 LR-56 Unit for the Transportation of Radioactive Liquids. . . . . . C-13

C-5 LR-56 Transporter Shielded Tank . . . . . . . . . . . ... . . C-14

C-6 LR-55 Transporter Load/Unioad Port . . . . . . . . . . . . . C-15

C-7 LR-56 Transporter Load/Unload Connections . . . . . . . . . . . . . C-16

C-8 NuPAC PAS-1 Shielded Transportation Package . . . . . . . . . . . C-19

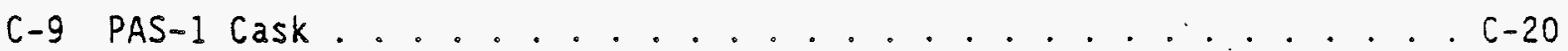


WHC-SD-WM-TA-160

Revision 0

APPENDIX C1

3- AND 25-L SAMPLER CONFIGURATION 
WHC-SD-WM-TA-160

Revision 0

This page intentionally left blank.

$$
c-4
$$


Figure C-1. Savannah River Site 3- and 25-L Sludge Collector Concept.

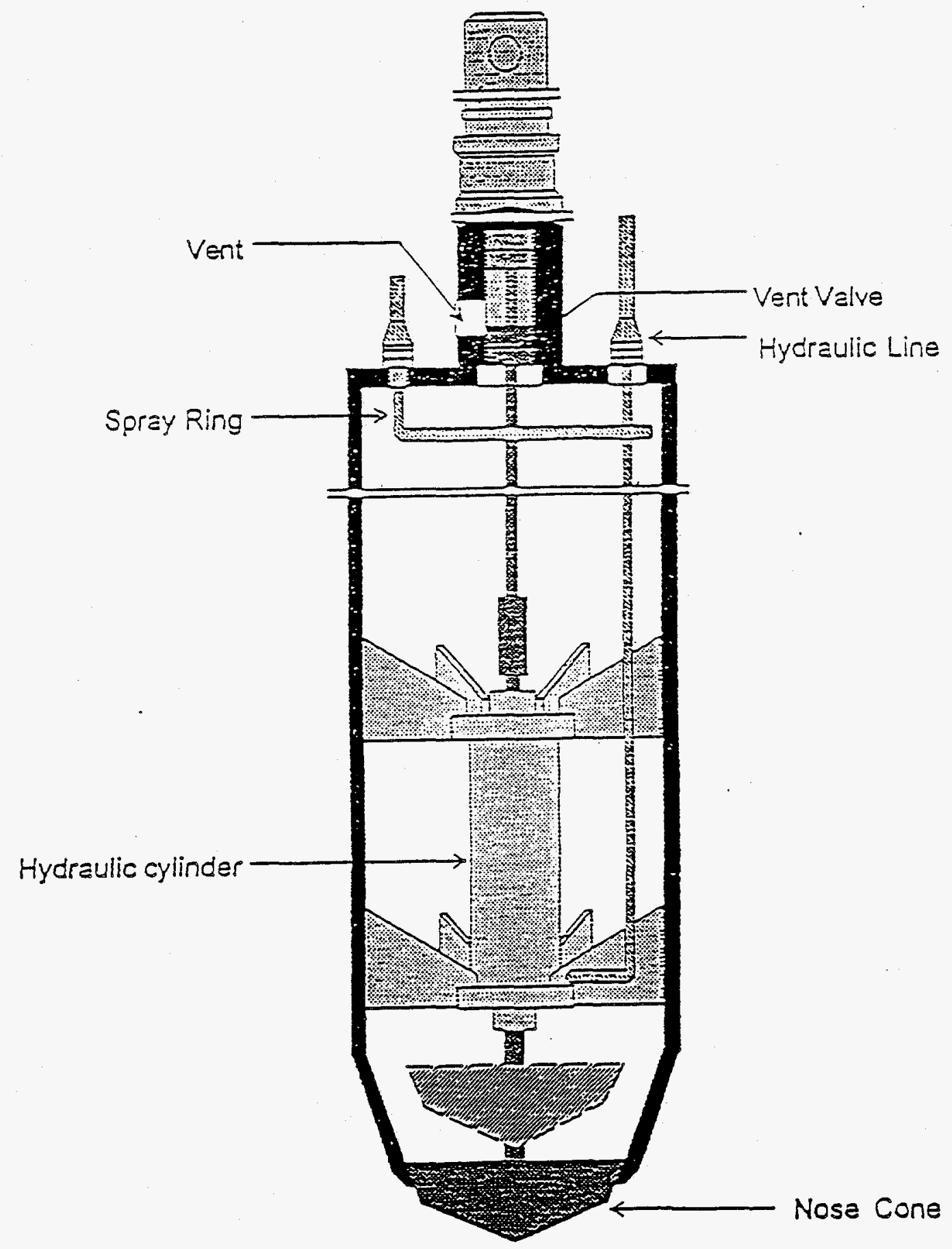


WHC-SD-WM-TA-160

Revision 0

This page intentionally left blank. 
WHC-SD-WM-TA-160

Revision 0

\section{APPENDIX C2}

25-L SAMPLER TANK RISER HANDLING INTERFACES 
WHC-SD-WM-TA-160

Revision 0

This page intentionally left blank. 
WHC-SD-WM-TA-160

Revision 0

Figure C-2. Mobile Waste Tank Riser 3- and 25-L Sampler Interface Concept.

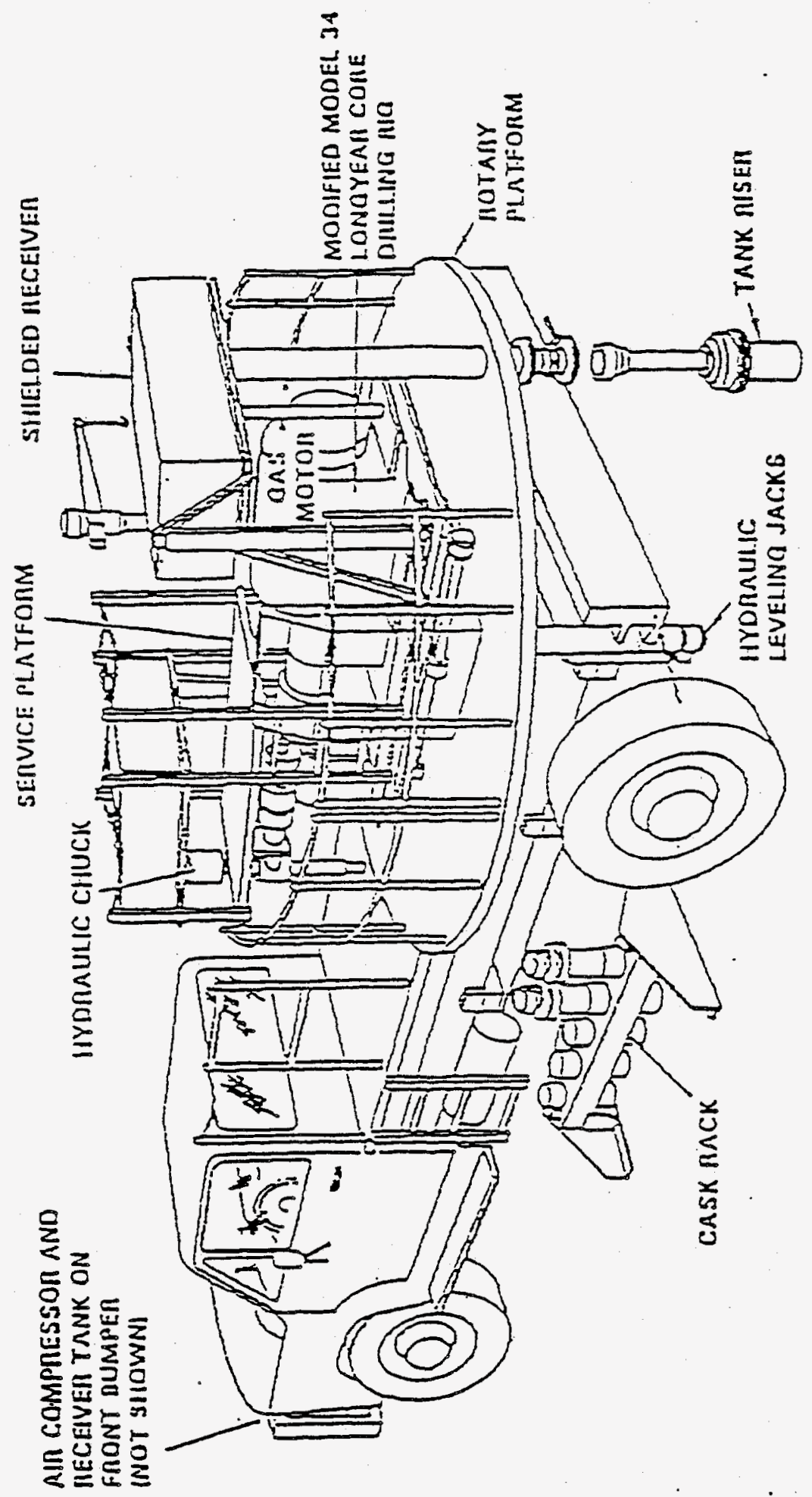




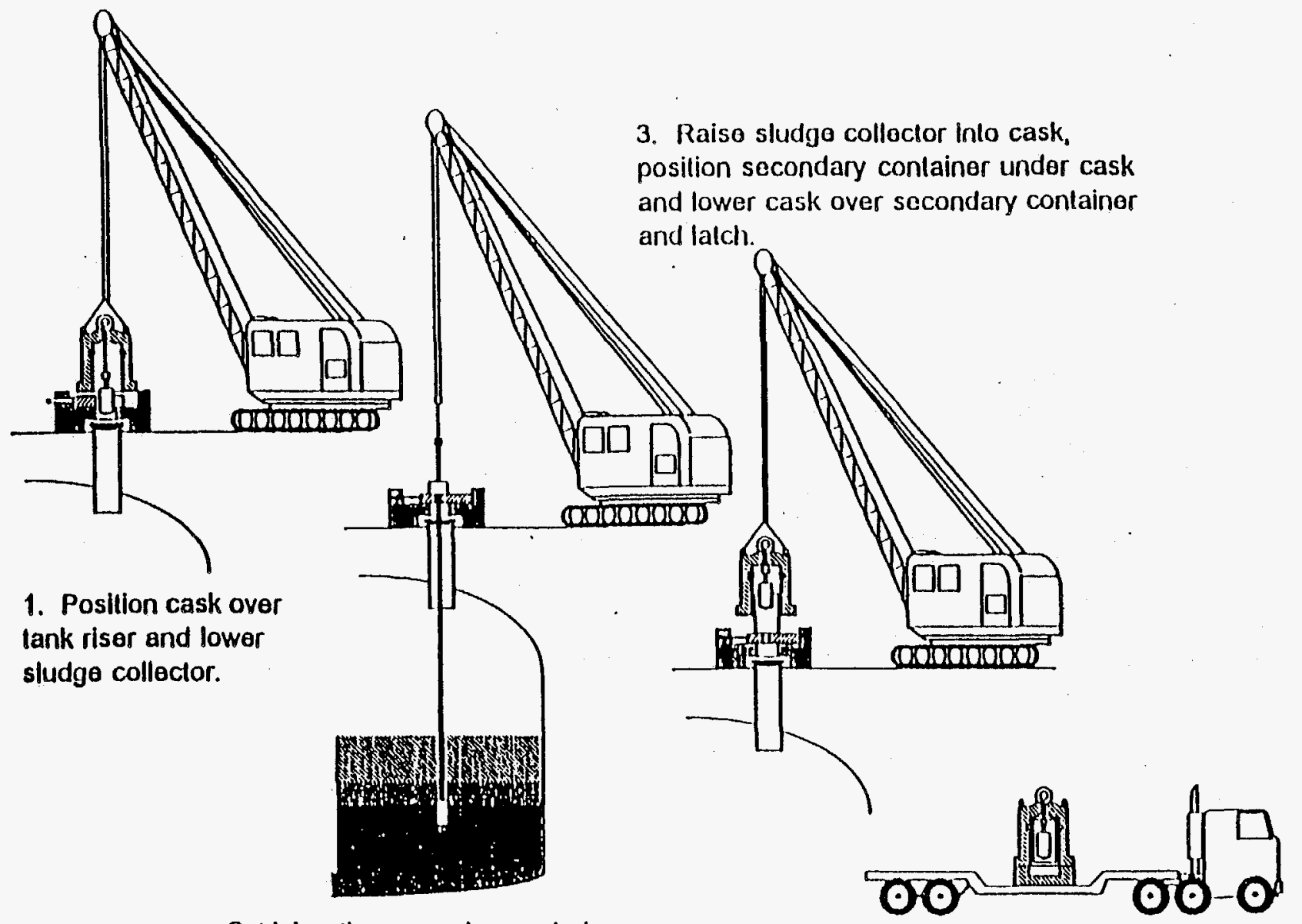

$\stackrel{n}{\frac{1}{5}}$

$\stackrel{\Phi}{\omega}$

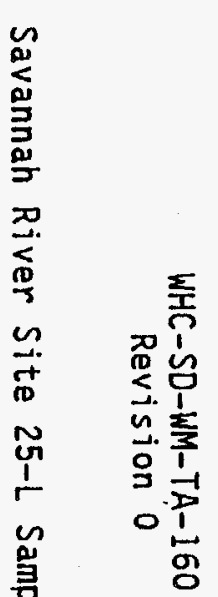

2. Using the crane lower sludge

4. Place cask back on base, secure collector into wasle, collect sample, and Iransport to recoiving facility. and wilhdraw sludge colleclor. 
WHC-SD-WM-TA-160

Revision 0

APPENDIX C3

LR-56 SHIELDED LIQUID WASTE TRANSPORTER

$C-11$ 
WHC-SD-WM-TA-160

Revision 0

This page intentionally left blank.

$c-12$ 
WHC-SD-WM-TA-160

Revision 0

Figure C-4. LR-56 Unit for the Transportation of Radioactive Liquids.

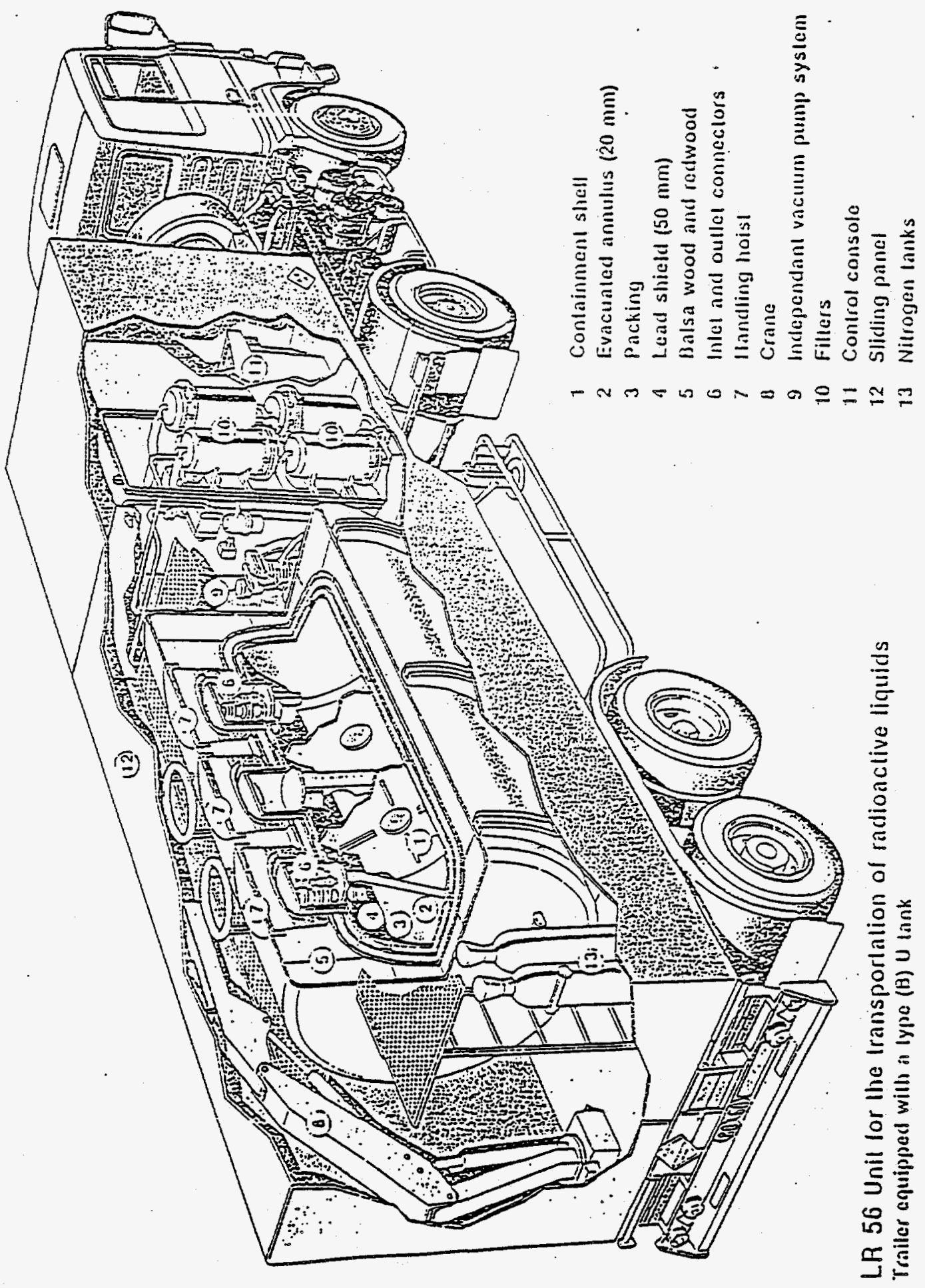


WHC-SD-WM-TA-160

Revision 0

Figure C-5. LR-56 Transporter Shielded Tank.

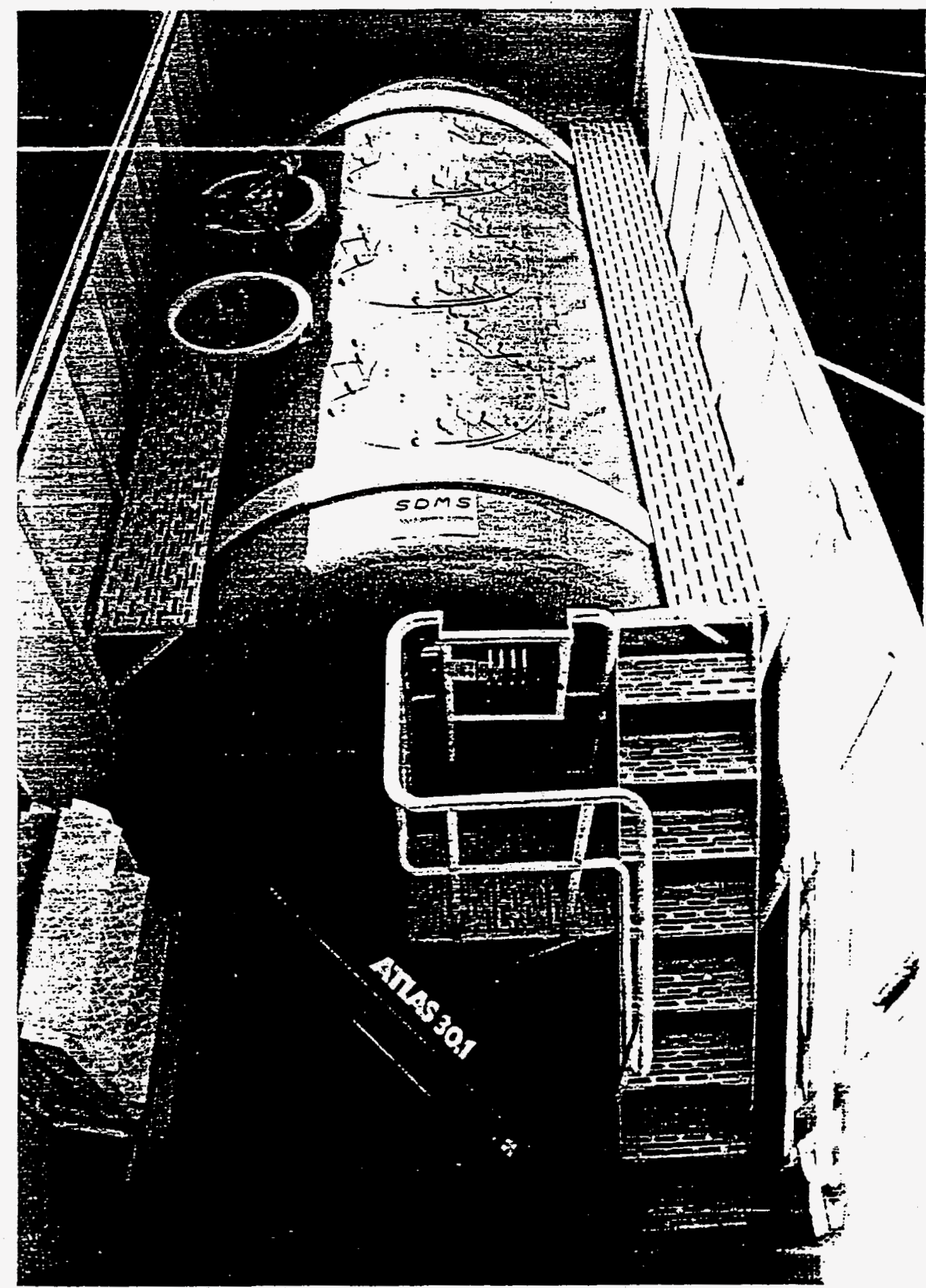


WHC-SO-WM-TA-160

Revision 0

Figure C-6. LR-56 Transporter Load/Unioad Port.

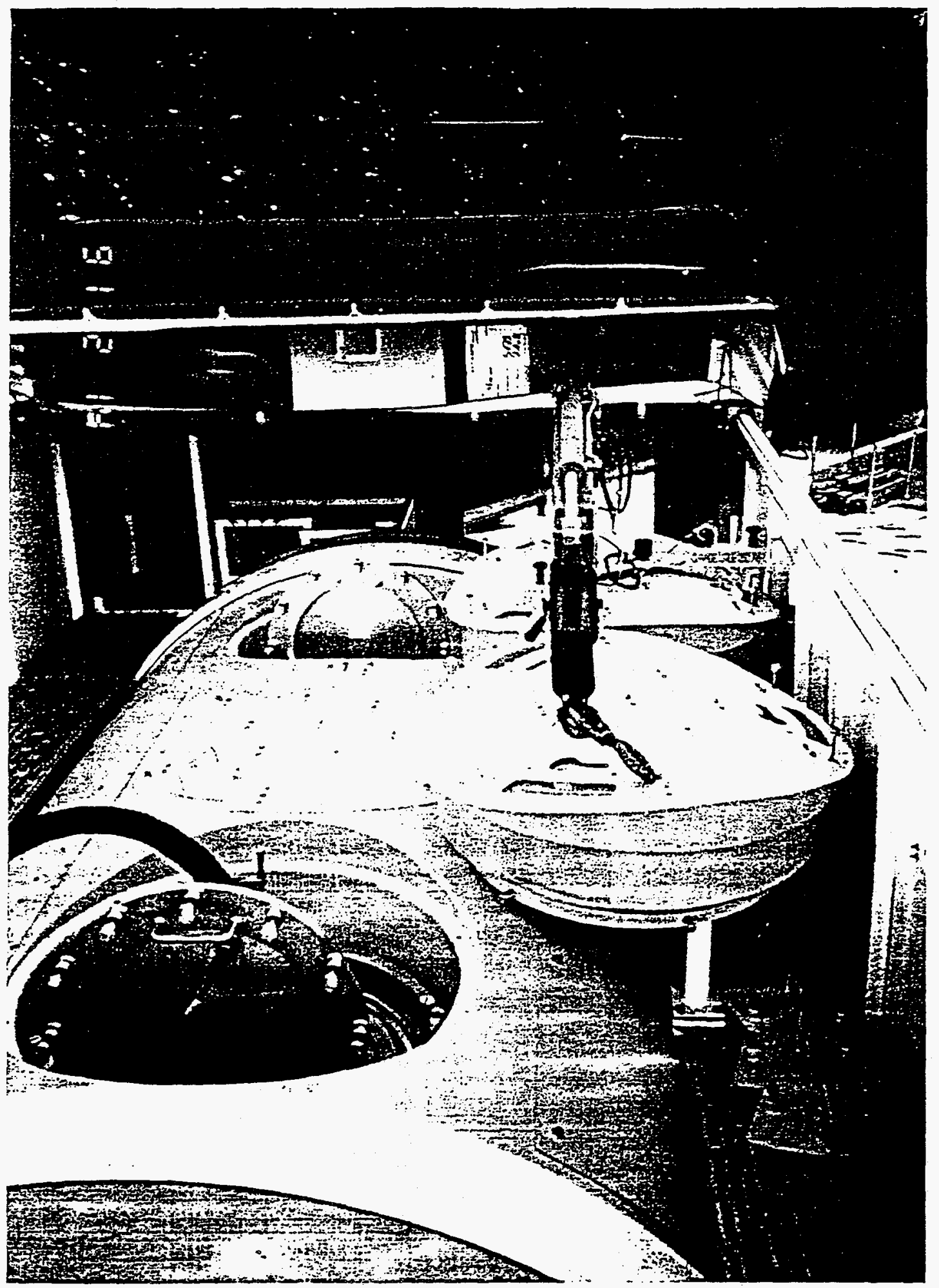


WHC-SD-WM-TA-160

Revision 0

Figure C-7. LR-56 Transporter Load/Unioad Connections.

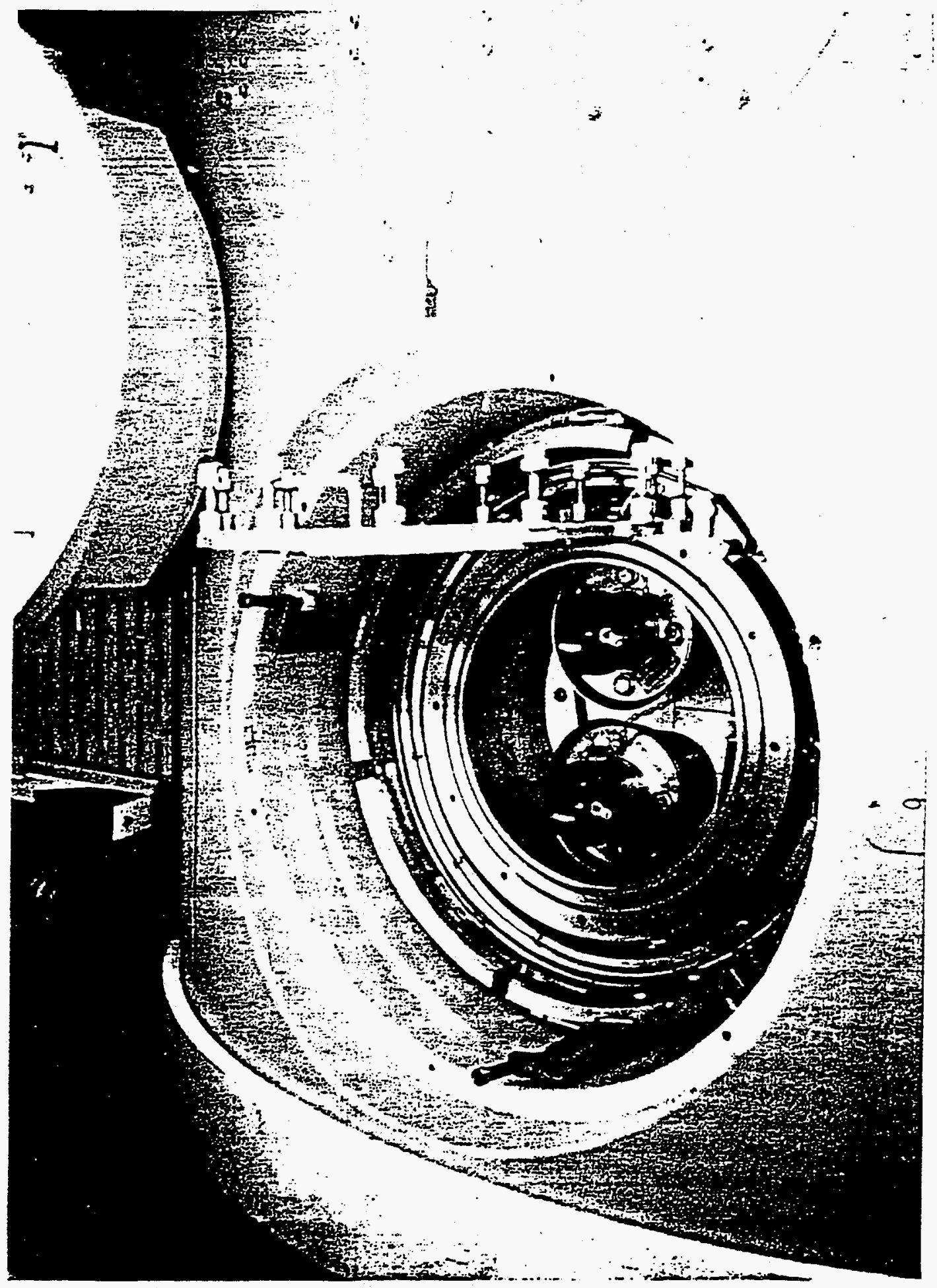


WHC-SD-WM-TA-160

Revision 0

APPENDIX C4

PAS-1 CASK

C-17 
WHC-SD-WM-TA-160

Revision 0

This page intentionally left blank.

C-18 
WHC-SD-WM-TA-160

Revision 0

Figure 6-8. NUPAC PAS-1 Shielded Transportation Package.

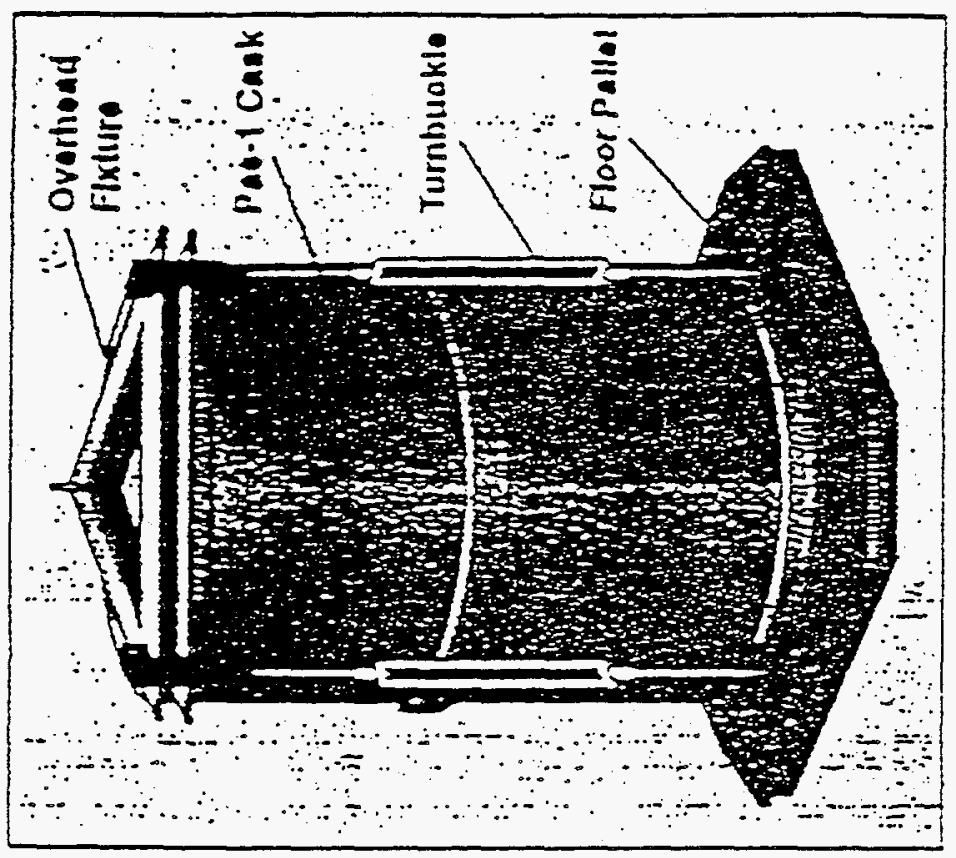

$\frac{U}{\stackrel{\Xi}{8}}$

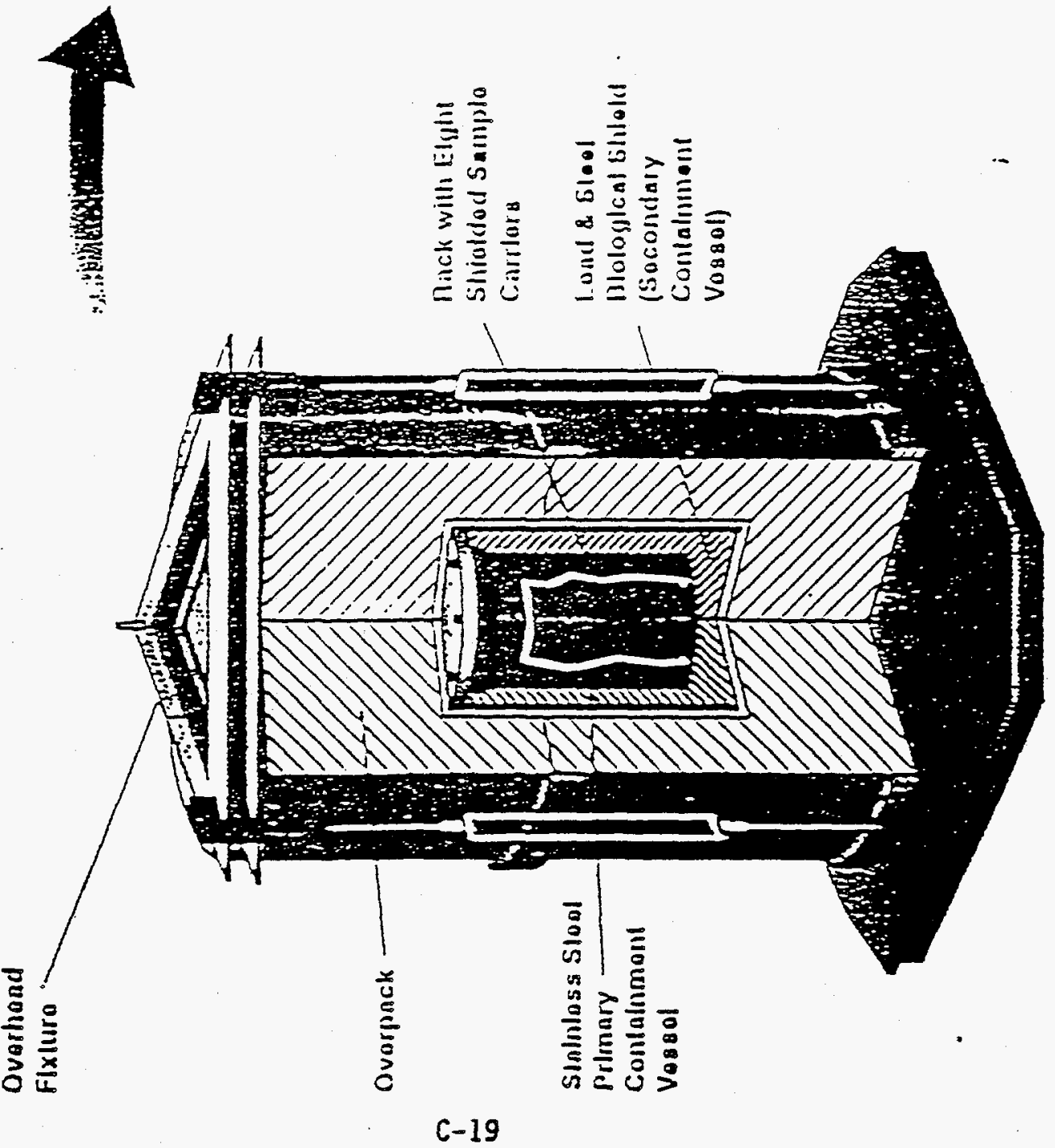




$$
\text { WHC-SO-WM-TA-160. }
$$

Revision 0

Figure C-9. PAS-1 Cask.

- Double containment with double O-ring seals

- Bore seal on primary vessel ( $8,3 / 8$ in. bolts).

- Face seal on secondary vessel $(8,1$ in. bolts)

- Leak testable to $10^{-7} \mathrm{~atm}-\mathrm{cc} / \mathrm{sec}$ (defined as "leaktight" by ANSI). .

- Shielding - 5.1 in. lead and 0.75 in. steel

- Foam filled overpack secured with $8,3 / 4$ in. bolts

- Marimum gross weight of 13,000 lbs.

- Sample cask weighs up to 1,375 lbs. 
WHC-SD-WM-TA-160

Revision 0

APPENDIX D

SITE SURVEYS

D-1 
WHC-SD-WM-TA-160

Revision 0

\section{CONTENTS}

DI PRELIMINARY SITE CONTACTS AND RESPONSES . . . . . . . . . . . D-5

D2 SITE ASSESSMENT DATA . . . . . . . . . . . . . . . . . D-11

D3 SAMPLE SITE GO-NO-GO ANALYSIS, 222-S LABORATORY . . . . . . . . D-53

\section{LIST OF FIGURES}

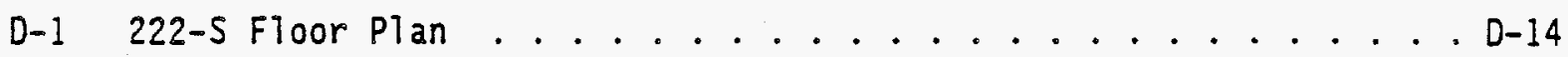

D-2 222-S Environmental Hot Cell Expansion ............. . D-15

D-3 ANL-East Building 200 . . . . . . . . . . . . . D-17

D-4 ANL-East Building 200 Hot Cells.............. . . . . . . .

D-5 324 Building Simplified Floor Plans (First Floor) . . . . . . D-20

D-6 Radiochemical Engineering Cells . . . . . . . . . . . . . D-21

D-7 Shielded Materials Facility................. D-22

D-8 325-A Building Floor Plan . . . . . . . . . . . . D-23

D-9 325-A Hot Cells .................. D-24

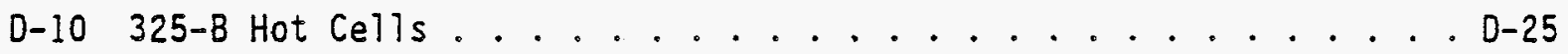

D-11 327 Building Postirradiation Testing Laboratory . . . . . . . . D-26

D-12 Waste Encapsulation and Storage Facility Cell Area Arrangement . . 0-28

D-13 Waste Encapsulation and Storage Facility First and Second

Floor Plan ................. . . D-29

D-14 Waste Encapsulation and Storage Facility Cell Cross-Sectional

View .................... D-30

D-15 Los Alamos National Laboratory MST-5 Hot Cell Facility . . . . . D-32

D-16 Fuels and Materials Examination Facility Arrangement . . . . . . D-34

D-17 Fuels and Materials Examination Facility 42-ft 6-in. Level . . . D-35

D-18 Fuels and Materials Examination Facility Building Main

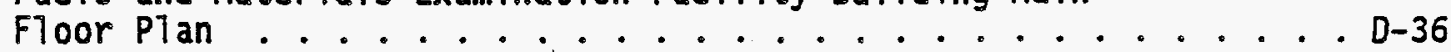




\section{WHC-SD-WM-TA-160 \\ Revision 0}

\section{LIST OF FIGURES (cont)}

D-19 Fuels and Materials Examination Facility 21-ft 3-in. Level . . D-37

D-20 Fuels and Materials Examination Facility (-)35-ft 0 -in. Level . D-38

D-21 ANL-W Analytical Laboratory Cel7s - Plan View . . . . . . . D-40

D-22 ANL-W Analytical Laboratory Ce11 - Elevation View ....... D-41

0-23 Hot Fuel Examination Facility Argonne National Laboratory-W. . . 0-42

D-24 Fuel Cycle Facility Argonne National Laboratory-W . . . . . . . D-43

D-25 Building 4501 - First Floor Plan (Cross-Hatched Areas

Radiation Zones) .............. . . D-46

D-26 Building 2026 - Plan of Oak Ridge National Laboratory

High-Radiation-Level Analytical Laboratory (First Floor) . . . . D-47

0-27 Building 2026 - Typical Work Cell Cross-Section . . . . . . . D-48

D-28 Building 3517 Arrangement . . . . . . . . . . . D-49

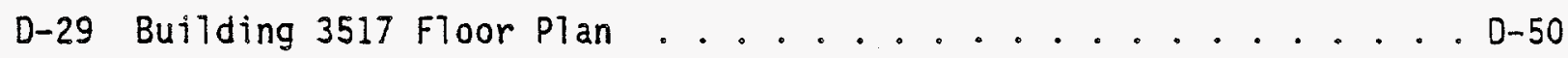

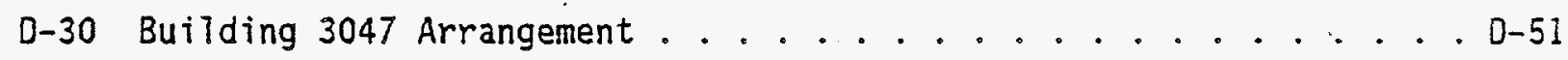

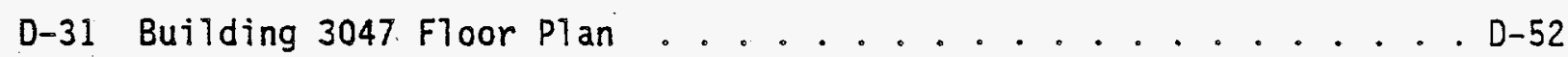

\section{LIST OF TABLES}

D-1 Preliminary Hot Test Siting Evaluation ......... D-7

D-2 Preliminary Site Evaluation Legend .......... D-8

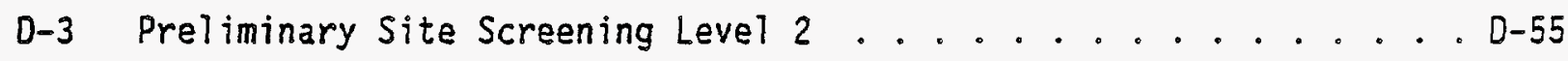


WHC-SO-WM-TA-160

Revision 0

This page intentionally left blank. 
WHC-SD-WM-TA-160

Revision 0

APPENDIX DI

PRELIMINARY SITE CONTACTS AND RESPONSES 
WHC-SD-WM-TA-160

Revision 0

This page intentionally left blank. 


\begin{tabular}{|c|c|c|c|c|c|c|c|c|c|c|}
\hline & A & B & C & D & $\mathbf{E}$ & $F$ & G & "1 & I & J \\
\hline sites & $\begin{array}{l}\text { Hot cells } \\
\text { Availlable }\end{array}$ & $\begin{array}{l}\text { Mot Labs } \\
\text { Available }\end{array}$ & $\begin{array}{l}\text { Curle Loading } \\
\text { Acseptoble }\end{array}$ & $\begin{array}{c}\text { facilitity } \\
\text { SAR }\end{array}$ & $\begin{array}{l}\text { Analytical } \\
\text { Capubility }\end{array}$ & $\begin{array}{l}\text { Sraff } \\
\text { Avaiflablo }\end{array}$ & $\begin{array}{l}\text { Mot Lab } \\
\text { incerest }\end{array}$ & $\begin{array}{l}\text { Process Dev./ } \\
\text { resting Interest }\end{array}$ & $\begin{array}{l}\text { MEPA } \\
\text { Bounded } \\
\text { Bowded }\end{array}$ & $\begin{array}{l}\text { Prituary site } \\
\text { contacts }\end{array}$ \\
\hline LANL & 1 & 1 & 1 & 1 & $1-7$ & 1,3 & 1 & 1 & $\operatorname{Yes}^{x}$ & Bob villarreal \\
\hline${ }^{*}$ ANL $-E$ & 1 & 1 & J & 1 & $1-7$ & 3 & 12 & $1 ?$ & No & $\begin{array}{l}\text { David Green } \\
\text { Doul Graceyk }\end{array}$ \\
\hline$\star A M L-W$ & $1 ?$ & 1 & 1 & 1 & $1,2,3,6,7$ & 3 & 1 & 1 & No & Jahn Krsul \\
\hline *LITCO & 2 & 1 & 2 & 1 & $1-7$ & 1 & 1 & 1 & Yes ${ }^{x}$ & $\begin{array}{l}\text { Leroy Lewis } \\
\text { Charlic Heggert-DoE }\end{array}$ \\
\hline${ }^{\star} O R N L$ & 2 & 17 & 1 & 1 & $1-7$ & 3 & $1 ?$ & 1 & No & $\begin{array}{l}\text { Jim stokely/8ill } \\
\text { witkins } \\
\text { orad Patton }\end{array}$ \\
\hline tSRS & 3 & 2 & $=$ & - & - & - & 2 & 2 & - & Ion french \\
\hline HLNL & 3 & - & $=$ & -- & $\ldots$ & -- & - & 2 & -- & Price Russ \\
\hline tSNL & -- & -- & -- & -- & $-\cdots$ & - & 2 & 2 & -- & Larry Dustard \\
\hline $\begin{array}{c}\text { Ilanford } \\
324\end{array}$ & $\begin{array}{l}1 \text { SMF } \\
3 \text { RCE }\end{array}$ & 3 & 18 & 2 & $\begin{array}{l}8 \\
8 \\
\end{array}$ & $\begin{array}{c}2,3 \\
3\end{array}$ & $\begin{array}{l}2 \\
2 \\
\end{array}$ & $\begin{array}{l}1 \\
1\end{array}$ & No & $\begin{array}{l}\text { Jium Jarrets } \\
\text { Paut Carter-pok }\end{array}$ \\
\hline $\begin{array}{l}\text { Ilanford } \\
325\end{array}$ & 1 & 1 & $2 ?$ & 1 & $1-7$ & 1 & 1 & 1 & Yes & $\begin{array}{l}\text { Kurt sitvers } \\
\text { Pau! Carter-dok }\end{array}$ \\
\hline $\begin{array}{c}\text { Ulanford } \\
327\end{array}$ & 1,2 & 3 & 1 & 2 & 5,6 & 1 & 2 & 1 & No & $\begin{array}{l}\text { Jina Jarrest } \\
\text { Paul Carter-DoE }\end{array}$ \\
\hline $\begin{array}{r}\text { Hanford } \\
222-5 \\
\end{array}$ & 1 & 1 & 2 & 1 & $1-7$ & 1 & 1 & 1 & Yes & $\begin{array}{l}\text { Dave Dodd } \\
\text { Paul Carter-Dok }\end{array}$ \\
\hline $\begin{array}{c}\text { Ilanford } \\
\text { WESF }\end{array}$ & $2 ?$ & 3 & 1 & $1 ?$ & 8 & 3 & 2 & $1 ?$ & No & Kent Smicls \\
\hline
\end{tabular}

To survey/responses received as of November 10,1994 data pretiminary.

+ Telephone call with $C$. Stroup and G. llowden

$x$ Requires review of existing Ells questionnaire to deternine need for additonal NEPA actions. 
WHC-SD-WM-TA-160

Revision 0

Table D-2. Preliminary Site Evaluation Legend. (2 sheets)

PRELIMINARY SITE EVALUATION LEGEND

(Circle Number Most Representative of Your Capability)

Site: Contact:

Phone:

Building:

Column A

1 Hot cells available beginning January 1995 through 1998

2 Hot cells available beginning January 1996 through 1998

3 Hot cells are not available

4 No hot cells in building

Column B

$\begin{array}{ll}\text { Hot lab capabilities available beginning January } 1995-1998 \\ 2 & \text { Hot lab capabilities available beginning January } 1996-1998 \\ 3 & \text { Hot lab capabilities not available } \\ 4 & \text { No hot lab capability in builaing }\end{array}$

Column $c$

$\begin{array}{ll}1 & \text { Celis capable of up to } 2000 \mathrm{Ci} / \mathrm{cell} \\ 2 & \text { Cells capable of up to } 200 \mathrm{Ci} / \mathrm{cell} \\ 3 & \text { Cells capable of up to } 10 \mathrm{Ci} / \mathrm{cell} \\ 4 & \text { Building limit: }\end{array}$

COlumn D

\begin{tabular}{ll}
\hline I & SAR Documentation for up to $2000 \mathrm{Ci} / \mathrm{Cell}$ \\
2 & SAR Documentation for up to $200 \mathrm{Ci} / \mathrm{cell}$ \\
3 & SAR Documentation for up to $10 \mathrm{Ci} / \mathrm{cell}$ \\
4 & Building SAR Iimit:
\end{tabular}

Column E

\begin{tabular}{ll}
\hline 1 & Analytical equipment for gamma radionuclides \\
2 & Analytical equipment and methodology for Sr and TC \\
3 & Analytical equipment and methodology for particle size \\
4 & Analysis of ion exchange resin for deformation and degradation \\
5 & Total organic carbon (TOC), semi-volatile organic and \\
complexant organic analysis instruments, standards and \\
methodology \\
6 Metals analysis, including ICF/AES and ICP/Ms \\
7 Ion chromatography for anions \\
None of the above available in this building. Available \\
Bld:
\end{tabular}

Column $F$
$1 \quad$ Staff available to support work beginning January 1995
2 Staff available to support work beginning July 1995
3 New staff hiring and training required
4 Staff not available 
WHC-SD-WM-TA-160

Revision 0

Table D-2. Preliminary Site Evaluation Legend. (2 sheets)

Column G

1 Can support hot lab work with staff and facilities

2 Cannot support hot lab work

Column H

1 Can support process development testing with staff. and facilities

2 Cannot support process development work

column I

Y Candidate facility has existing NEPA documentation that would bound this added work scope

YX Candidate facility has NEPA documentation that would probably cover the scope of work. Would need EH\&S questionnaire review to confirm

N Existing NEPA documentation would not cover this work. Revised NEPA would be required. 
WHC-SD-WM-TA-160

Revision 0

This page intentionally left blank. 
WHC-SD-WM-TA-160

Revision 0

\section{APPENDIX 02}

SITE ASSESSMENT DATA

D-11 


$$
\text { WHC-SD-WM-TA-160 }
$$

Revision 0

This page intentionally left blank. 


\section{Hot Cell/Site Evaluation}

Site $222-S$

\begin{tabular}{|c|c|c|c|c|c|}
\hline Building number: & & & & $11 \mathrm{a}$ & . \\
\hline Number of cells: & $1 \mathrm{~A}$ & IE1 & if & Pods (2) & 1E2 \\
\hline \multicolumn{6}{|l|}{ Attribute } \\
\hline Hot cell size & $50 \times 54$ & $61 \times 61$ & $5^{1} \times 18^{1}$ & $51 \times 61$ & $51 \times 81$ \\
\hline Equipment access & $31 \times 31$. & $2.5^{\circ} \times 5^{\circ}$ & $5 ! \times 81$ & $31 \times 30$ & $21 \times 31$ \\
\hline Service access & 4 a 4" & $\begin{array}{l}9 " \times 17 " \\
3 \text { a } 4 " \phi\end{array}$ & $\begin{array}{l}911 \times 17^{11} \\
6 \text { a } 611 \phi\end{array}$ & $\begin{array}{c}9 " 1 \times 17^{\prime \prime} \\
1 \text { a } 12^{\prime \prime} \phi_{;} 1^{\prime \prime} \text { a } \text { 6 }^{\prime \prime} \phi\end{array}$ & $\begin{array}{l}9 " 1 \times 17^{\prime \prime} \\
4 \text { a } 4 " \phi\end{array}$ \\
\hline ci loading capability & $\leq 2,000 \mathrm{Ci}$ & $\leq 2,000 \mathrm{Ci}$ & $\leq 2,000 \mathrm{Ci}$ & $\leq 2,000 \mathrm{Ci}$ & $\leq 2,000 \mathrm{Ci}$ \\
\hline $\begin{array}{r}\text { Cell availability dates: } \\
\text { Start } \\
\text { End }\end{array}$ & $\begin{array}{l}1 / 95 \\
6 / 98\end{array}$ & $\begin{array}{l}1 / 96 \\
6 / 98\end{array}$ & $\begin{array}{l}3 / 95 \\
6 / 98\end{array}$ & $\begin{array}{l}1 / 95 \\
6 / 98\end{array}$ & $\begin{array}{l}1 / 96 \\
6 / 98\end{array}$ \\
\hline \multicolumn{6}{|l|}{$\begin{array}{l}\text { Speciat onalytical } \\
\text { equipment in facility }\end{array}$} \\
\hline Hot hoods & Yes & Yes & Yes & Yes & res \\
\hline $\begin{array}{r}\text { Onsite waste disposal: } \\
\text { Primary } \\
\text { Secondary }\end{array}$ & $\begin{array}{c}\text { Back to tank } \\
\text { Lab pack (organics) }\end{array}$ & $\begin{array}{l}\text { Back to tank } \\
\text { Lab pack (organics) }\end{array}$ & $\begin{array}{c}\text { Back to tank } \\
\text { Lab pack (organics) }\end{array}$ & $\begin{array}{c}\text { Back to tank } \\
\text { Lab pack (organics) }\end{array}$ & $\begin{array}{c}\text { Back to cank } \\
\text { Lab pack (organics) }\end{array}$ \\
\hline $\begin{array}{l}\text { Estimated cost for } \\
\text { cell cleanout and } \\
\text { commissioning }\end{array}$ & $\$ 50 \mathrm{~K}$ & $\$ 500 \mathrm{~K}$ & $\$ 50 \mathrm{~K}$ & $\$ 0 K$ & $\$ 500 \mathrm{~K} ?$ \\
\hline
\end{tabular}

NOTE: To convert inches to cent imeters, mul tiply by 2.54 .

To convert feet to meters, multiply by 0.3048 .

*special analytical equipment needed with a value of more than $\$ 100 \mathrm{~K}$ and a 4 -month procurement time. 


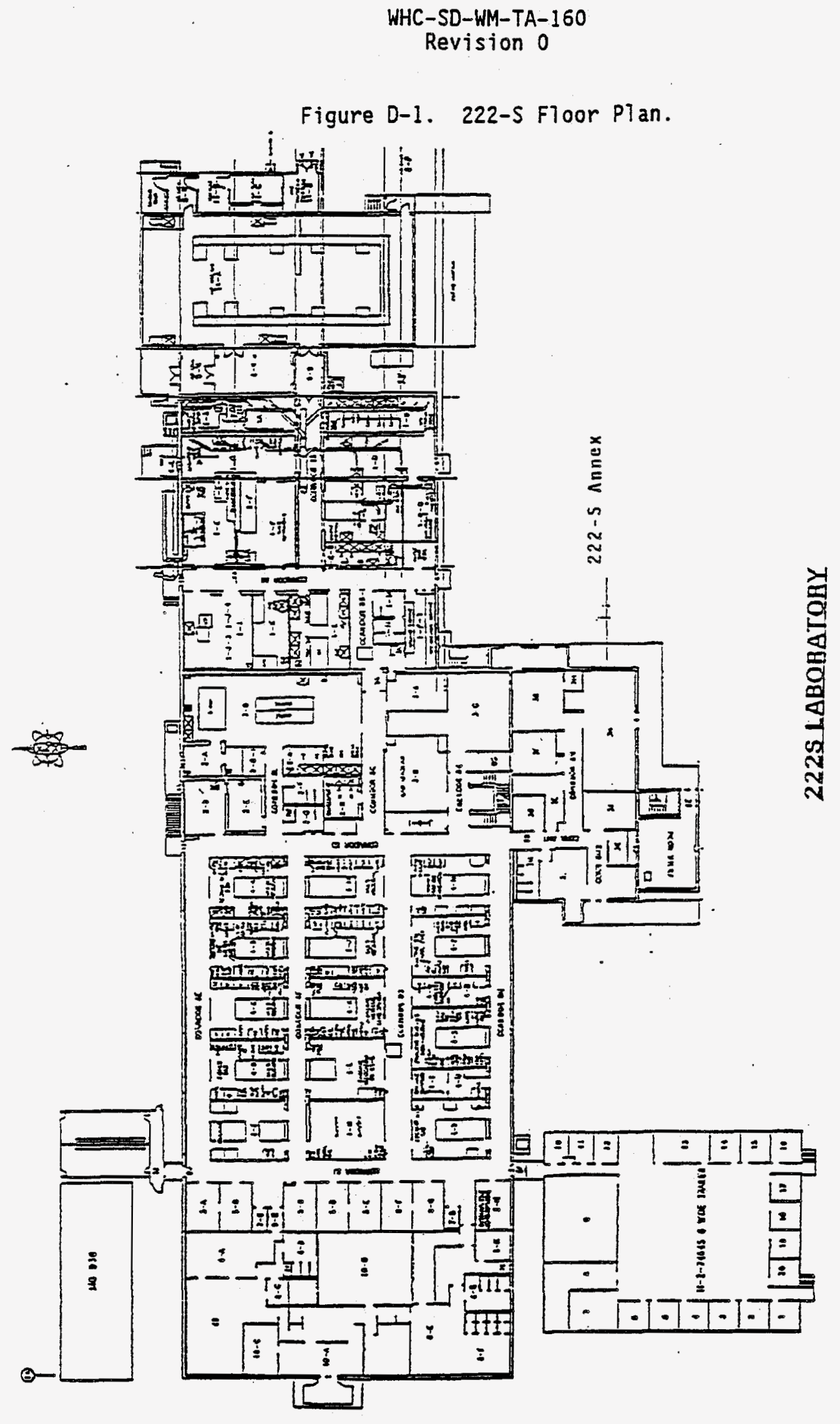


WHC-SD-WM-TA-160

Revision 0

Figure D-2. 222-S Environmenta] Hot Cel1 Expansion.

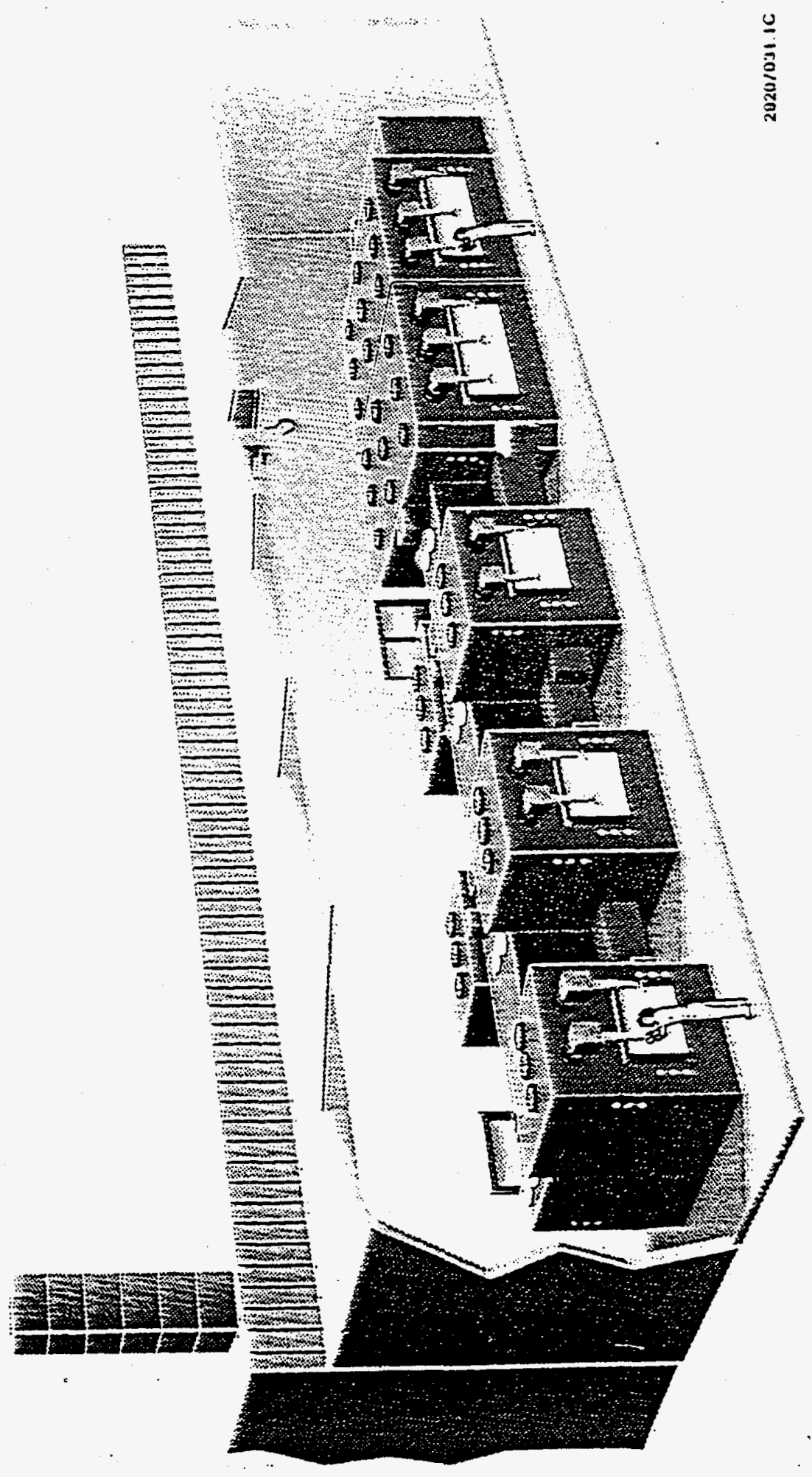

$0-15$ 


\section{Hot Cell/Site Evaluation}

Site ANL-East

\begin{tabular}{|c|c|c|c|}
\hline Bullding number: & 200 & 200 & 200 \\
\hline Number of cells: & 2 Analytical & 2 Kilo Curie & Mega. Curie \\
\hline \multicolumn{4}{|l|}{ Attribute } \\
\hline Hot cell size & $\begin{array}{rr}\# 1 & 121 \times 71 \\
\# 2 & 71 \times 71\end{array}$ & $\begin{array}{lrll}\# 1 & 14^{\prime} & \times & 14^{\prime} \\
\# 2 & 70^{\prime} & \times & 12^{\prime}\end{array}$ & $\sim 10^{\circ} \times 10^{\circ}$ \\
\hline Equipment access & $71 \times 70$ & $7^{\prime} \times 7^{\circ}$ & $7 \cdot \times 71$ \\
\hline Service access & $?$ & $?$ & $?$ \\
\hline cf loading capability & $30 \mathrm{ci}$ & $100 \mathrm{Ci}$ & $\leq 1$ M Ci \\
\hline $\begin{array}{r}\text { Cell availability dates: } \\
\text { Start } \\
\text { End }\end{array}$ & $\begin{array}{cc}\# 1 & \# 2 \\
1 / 95 & 1 / 95\end{array}$ & $\begin{array}{cc}\# 1 & \# 2 \\
1 / 95 & 1 / 95\end{array}$ & $\begin{array}{c}\# 1 \\
1 / 96\end{array}$ \\
\hline $\begin{array}{l}\text { Special analytical } \\
\text { equipment in facility }\end{array}$ & SEM/TEM & SEM/TEM & SEM/TEM \\
\hline Hot hoods & Yes & Yes & Yes \\
\hline $\begin{array}{r}\text { Onsite waste disposal: } \\
\text { Primary } \\
\text { Secondary }\end{array}$ & $\begin{array}{l}\text { Ship to Hanford } \\
\text { Ship to Hanford }\end{array}$ & $\begin{array}{l}\text { Ship to Hanford } \\
\text { Ship to Hanford }\end{array}$ & $\begin{array}{l}\text { Ship to Hanford } \\
\text { Ship to Hanford }\end{array}$ \\
\hline Estimated cost for cell & \$oK & $\$ 0 K$ & SOK \\
\hline
\end{tabular}

NOTE: To convert inches to centimeters, multiply by 2.54

to convert feet to meters, mul tiply by 0.3048

*Special analytical equipment needed with a value of more than $\$ 100 \mathrm{~K}$ and a 4 -month procurement $t$ ime.

SEM/TEM = Scanning electron microscope/transmission electron microscope 
WHC-SD-WM-TA-160

Revision 0

Figure D-3. ANL-East Building 200.
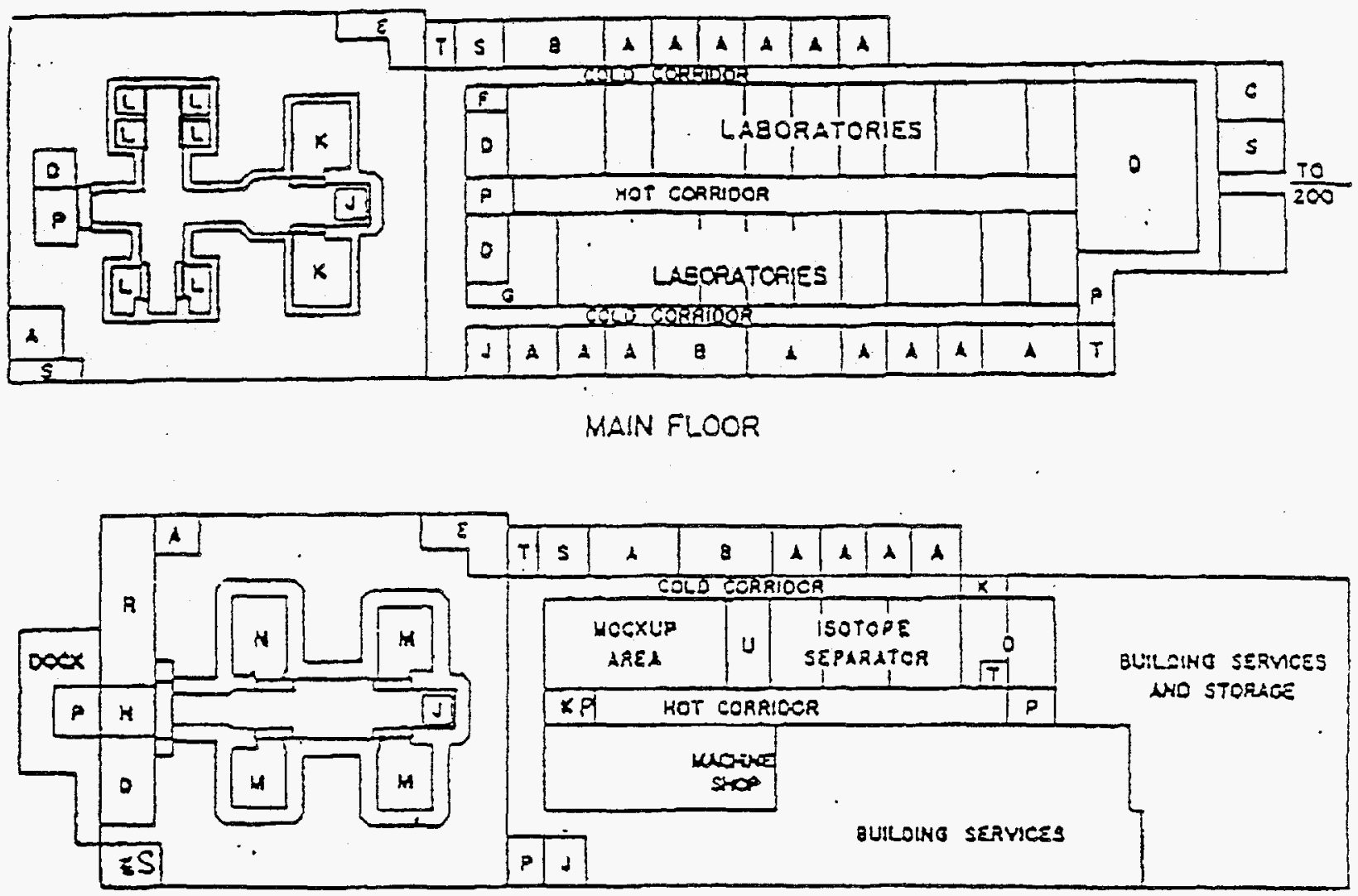

Lond Side 1320 is at

Wldth in care Sectlon: 95 lost

\section{SERVICE FLOOR}

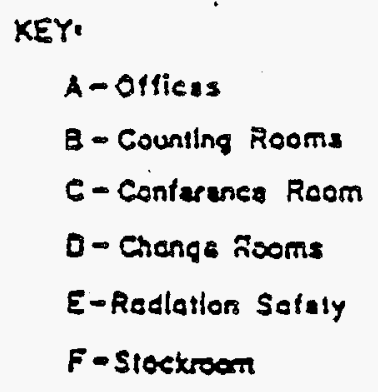

KEY.

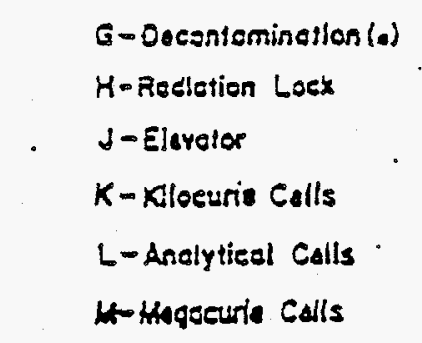

G-Decontominetlon (e)

N-Decontenination Call

P - Ale Lost

R-Rieciomotion Arso

S-Sigirs

T-Jenilar Closer

$u$ - Laboratory

Fig. A-1. Floor Plan of Shieided-Cell Facility 
Figure D-4. ANL-East Building 200 Hot Cel1s.
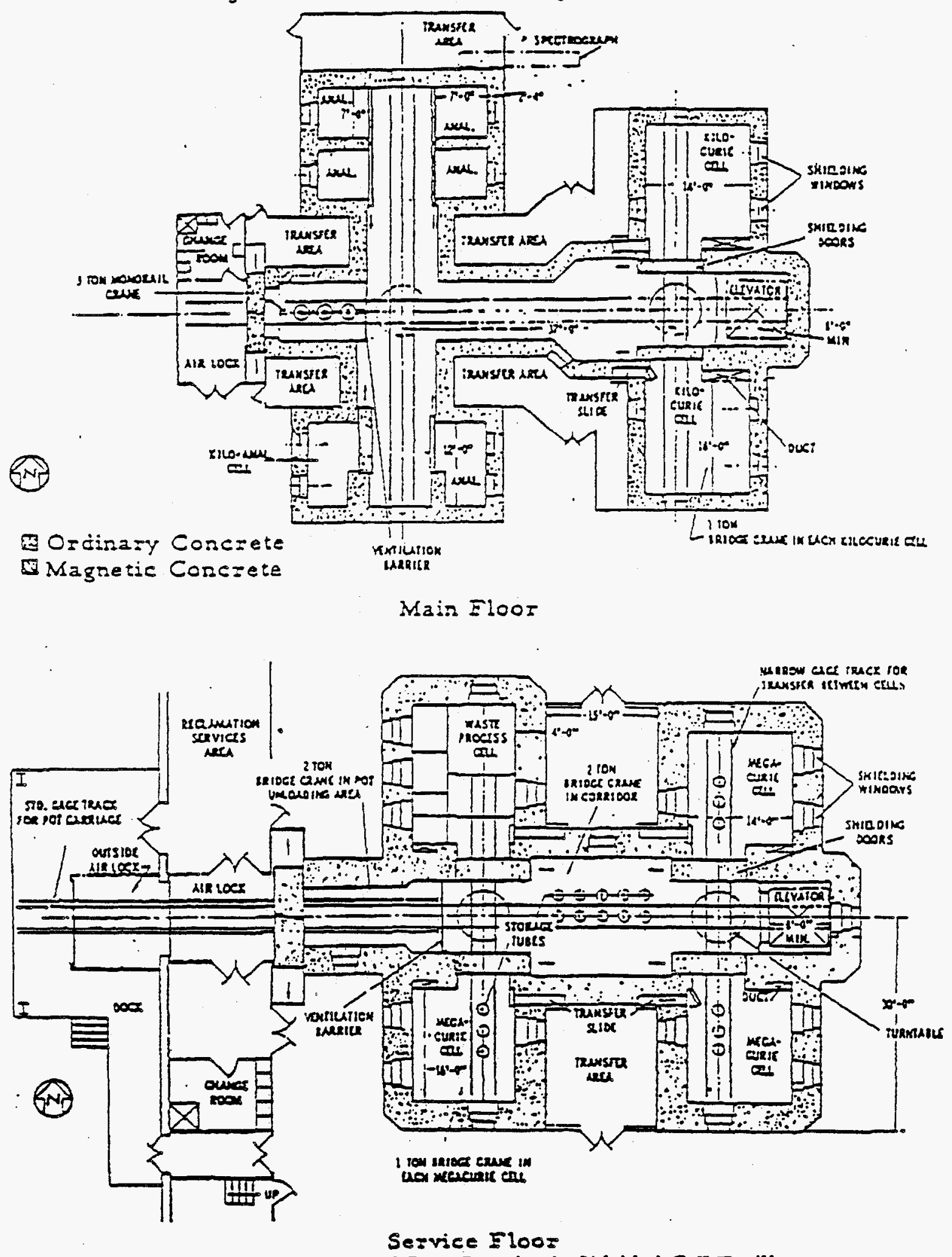

Fig. A-2. Fioor Plan of Cave Complex in Shielded-Cell Facility 


\section{Hot Cell/Site Evaluation}

Site Hanford - 300 Area

\begin{tabular}{|c|c|c|c|c|c|}
\hline Building number: & 324 RCE & $324 \mathrm{SMF}$ & $325-A$ & $325-8$ & 327 \\
\hline Number of cells: & $\begin{array}{l}1 \text { - c cell } \\
1-0 \text { cell }\end{array}$ & $\begin{array}{l}1 \text { w/8 sta. } \\
1 \text { w/11 sta. }\end{array}$ & $\begin{array}{l}1 \text { w/2 sta. } \\
2 \text { w/1 sta. }\end{array}$ & 6 & 5 \\
\hline \multicolumn{6}{|l|}{ Attribute } \\
\hline Hot cell size & 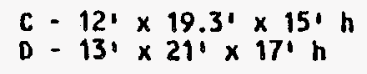 & 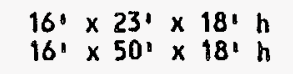 & $\begin{array}{r}A=6.51 \times 151 \times 151 \mathrm{~h} \\
B 8 C-6.5 \times 5.8 \times 15, \mathrm{~h}\end{array}$ & $60 \times 5.51 \times 6.25 \mathrm{~h}$ & $\begin{array}{l}4 \text { a } 61 \times 4.51 \times 4.51 \mathrm{~h} \\
1 \text { a } 10.25 \times 6.31 \times 8.3 \mathrm{~h}\end{array}$ \\
\hline Equipment access & $8 . \times 6 \cdot$ doors & $50 \times 71$ doors & $\begin{array}{c}61 \times 71 \text { door plus } 1311 \\
\text { port } / \text { cell }\end{array}$ & $26^{\prime \prime} \times 30^{\prime \prime \prime} \times 4211$ & $7 " \phi$ port or cell end wall \\
\hline Service access & $4 " 14-6 / c e l l$ & $4 " \phi 4 / \mathrm{sta}$. & & & $7 " \$ 2$ or more/cell \\
\hline Ci loading capabillity & $\leq 3 \mathrm{H} / \mathrm{cell}$ & $\leq 3 \mathrm{M} / \mathrm{cell}$ & $\leq 7,000$ & $\leq 2,000$ & $\leq 2,000$ \\
\hline $\begin{array}{r}\text { Cell availability dates: } \\
\text { Start } \\
\text { End }\end{array}$ & $\begin{array}{c}\text { C - 1/96, D }-1 / 95 \\
\text { Open }\end{array}$ & $\begin{array}{l}1 / 95 \\
\text { Open }\end{array}$ & $\begin{array}{l}2 / 95 \\
\text { Open }\end{array}$ & $\begin{array}{l}1 / 95 \\
\text { Open }\end{array}$ & $\begin{array}{l}1 / 95 \\
\text { Open }\end{array}$ \\
\hline $\begin{array}{l}\text { Special analytical } \\
\text { equipment in facility* }\end{array}$ & $\begin{array}{c}\text { None, this bldg. uses } \\
325 \text { 8ldg. labs }\end{array}$ & $\begin{array}{l}\text { None, this bldg. } \\
\text { uses } 325 \text { Bldg. labs }\end{array}$ & $\begin{array}{c}\text { None, this bldg. uses } 325 \\
\text { 8ldg. labs }\end{array}$ & ICP-AES & $\begin{array}{c}\text { None, this bldg. uses } 325 \\
\text { Bldg. labs }\end{array}$ \\
\hline Hot hoods & Yes & No & Yest & Yes & \\
\hline $\begin{array}{r}\text { Onsite waste disposal: } \\
\text { Primary } \\
\text { Secondary }\end{array}$ & $\begin{array}{l}\text { Ship to } 200 \text { Area } \\
\text { Ship to } 200 \text { Area }\end{array}$ & $\begin{array}{l}\text { Ship to } 200 \text { Area } \\
\text { Ship to } 200 \text { Area }\end{array}$ & $\begin{array}{l}\text { Ship to } 200 \text { Area } \\
\text { Ship to } 200 \text { Area }\end{array}$ & $\begin{array}{l}\text { Ship to } 200 \text { Area } \\
\text { Ship to } 200 \text { Area }\end{array}$ & $\begin{array}{l}\text { Ship to } 200 \text { Area } \\
\text { Ship to } 200 \text { Area }\end{array}$ \\
\hline $\begin{array}{l}\text { Estimated cost for } \\
\text { cell cl eanout and } \\
\text { commissioning }\end{array}$ & $\begin{array}{l}C \sim \$ 400 \mathrm{~K} \\
D=\$ 2,000 \mathrm{~K}\end{array}$ & $\begin{array}{l}-\$ 2,000 \mathrm{~K}-\text { south } \\
-\$ 250 \mathrm{~K}\end{array}$ & $\begin{array}{l}A-\$ 50 \mathrm{~K} \\
B-\$ 800 \mathrm{~K} \\
C-\$ 0\end{array}$ & $\$ 50 \mathrm{~K}$ & , \\
\hline
\end{tabular}

NOTE: To convert inches to centimeters, multiply by 2.54 .

To convert feet to meters, multiply by 0.3048 .

*Special analytical equipment needed with a value of more than $\$ 100 \mathrm{~K}$ and a 4 -month procurement time. +Small group of hot hoods available in basement.

\footnotetext{
ICP-AES = Inductively coupled plasma - atomic emission spectrometer

RCE $\quad$ Radiochemical engineering
}

SMF = shielded Materials facility 
WHC-SD-WM-TA-160
Revision 0

Figure D-5. 324 Building Simplified Floor Plans (First Floor).

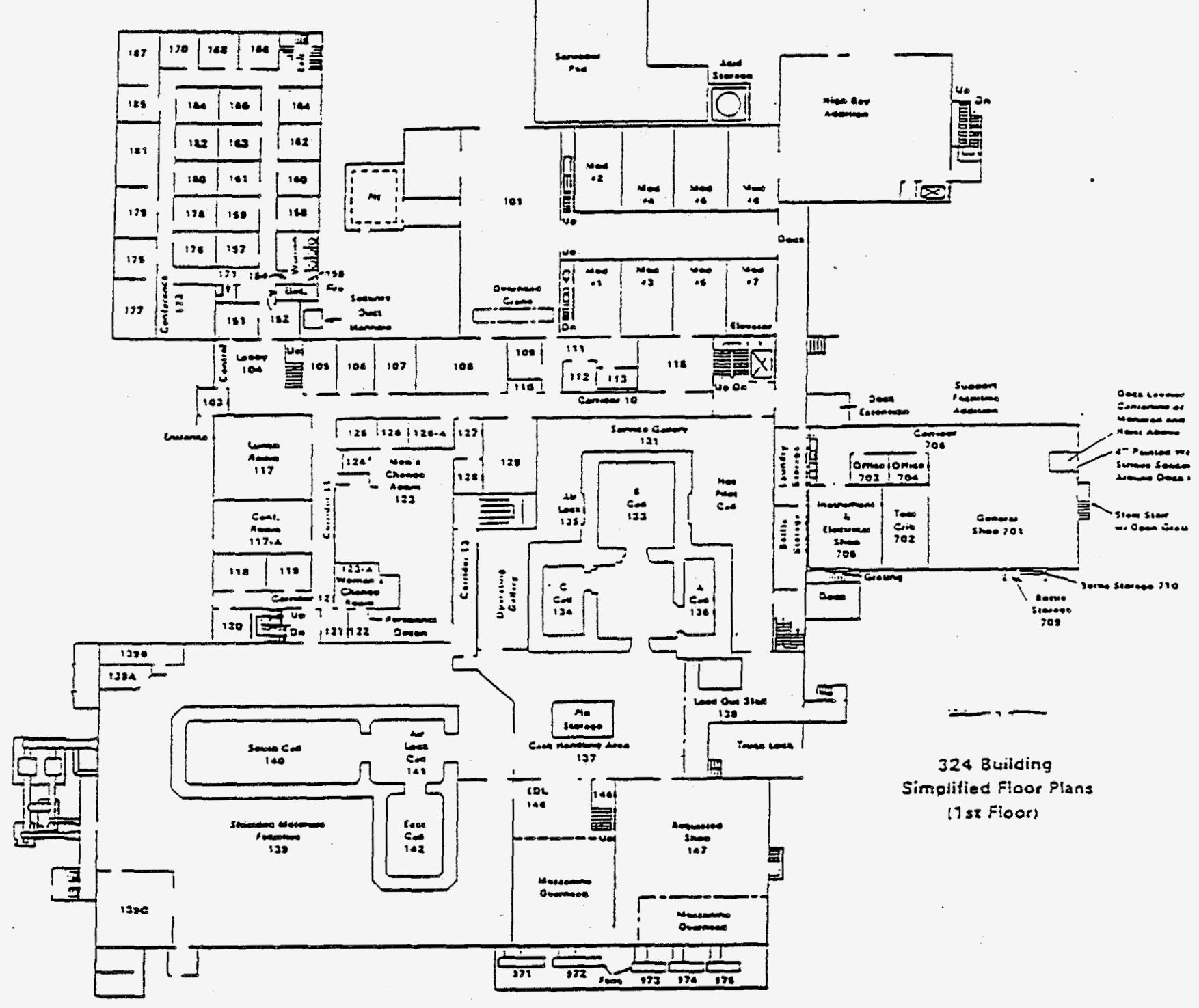


WHC-SD-WM-TA-160

Revision 0

Figure D-6. Radiochemical Engineering Cells.

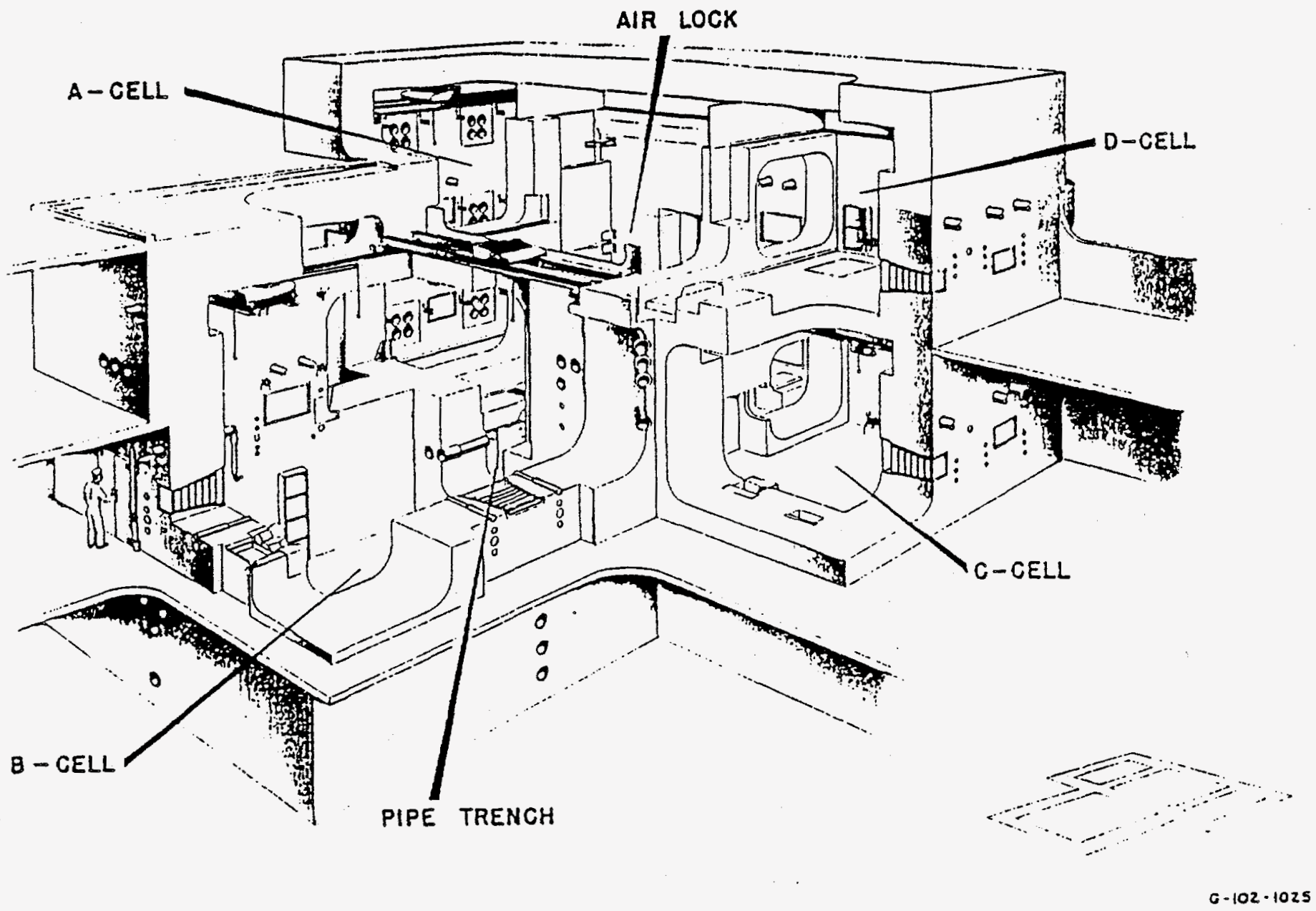


WHC-SD-WM-TA-160

Revision 0

Figure D-7. Shielded Materials Facility.

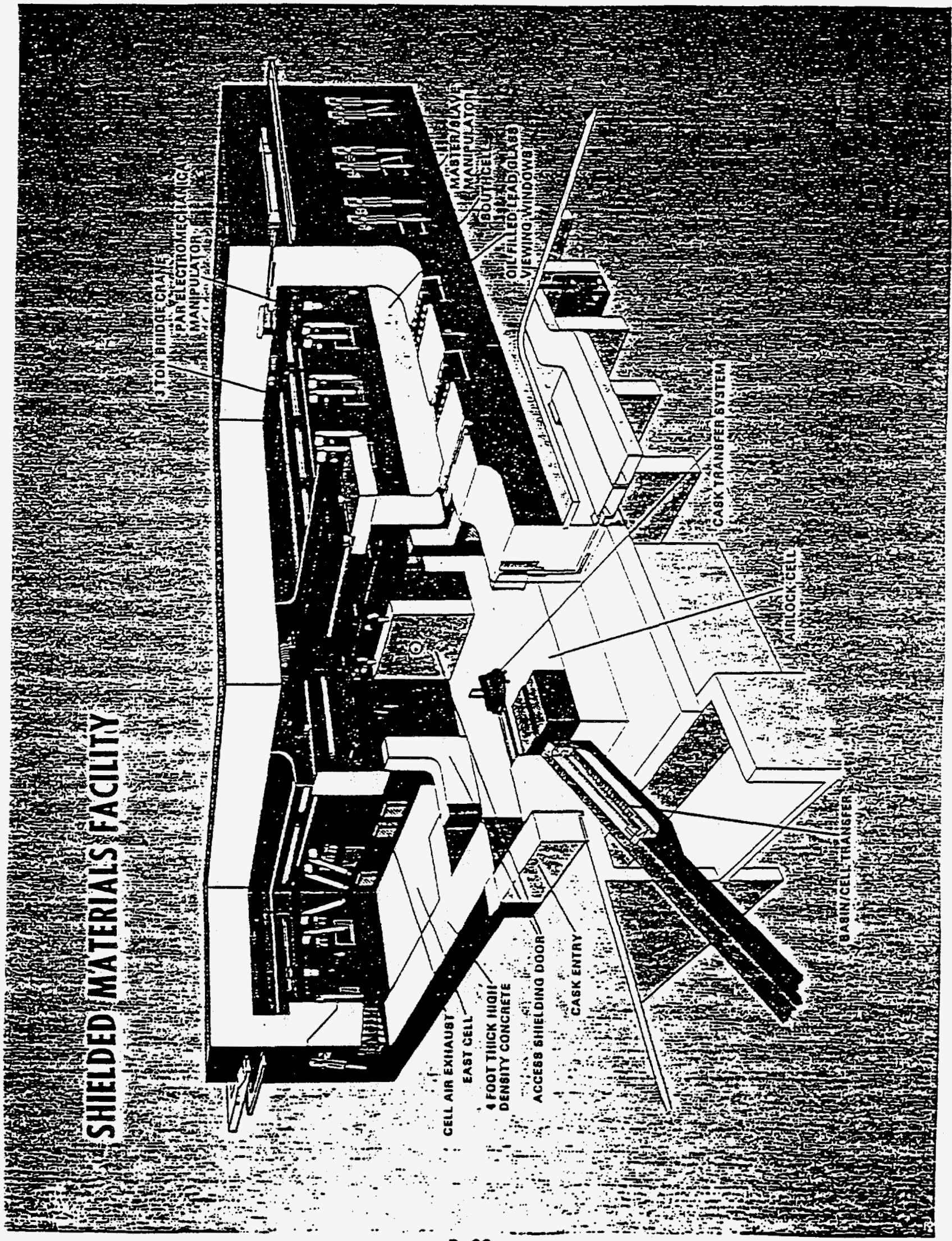


WHC-SD-WM-TA-160

Revision 0

Figure D-8. 325-A Building Floor Plan.

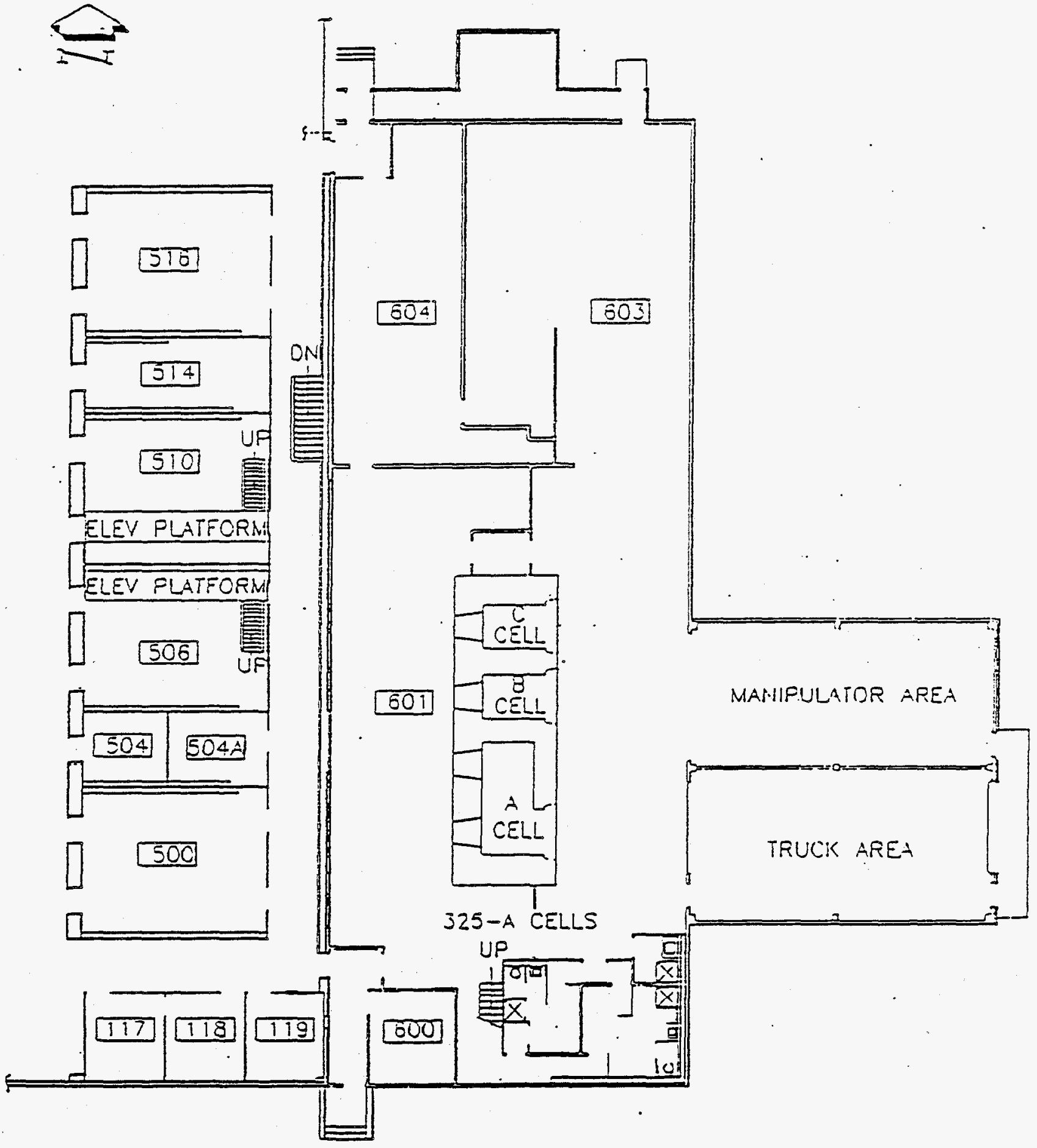


WHC-SD-WM-TA-160

Revision 0 .

Figure D-9. 325-A Hot Cells.

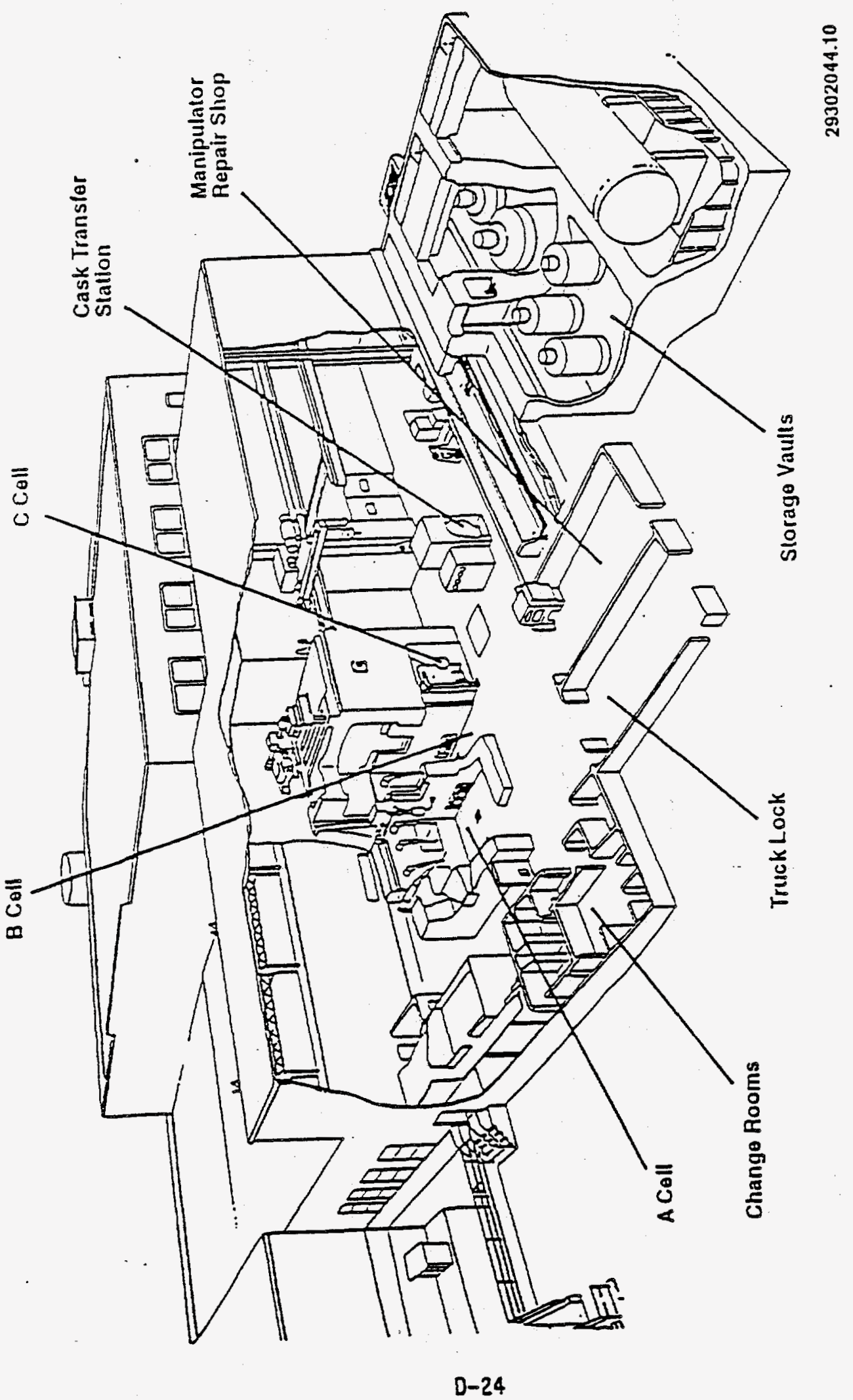


WHC-SD-WM-TA-160

Revision 0

Figure $0-10.325-B$ Hot Cells.

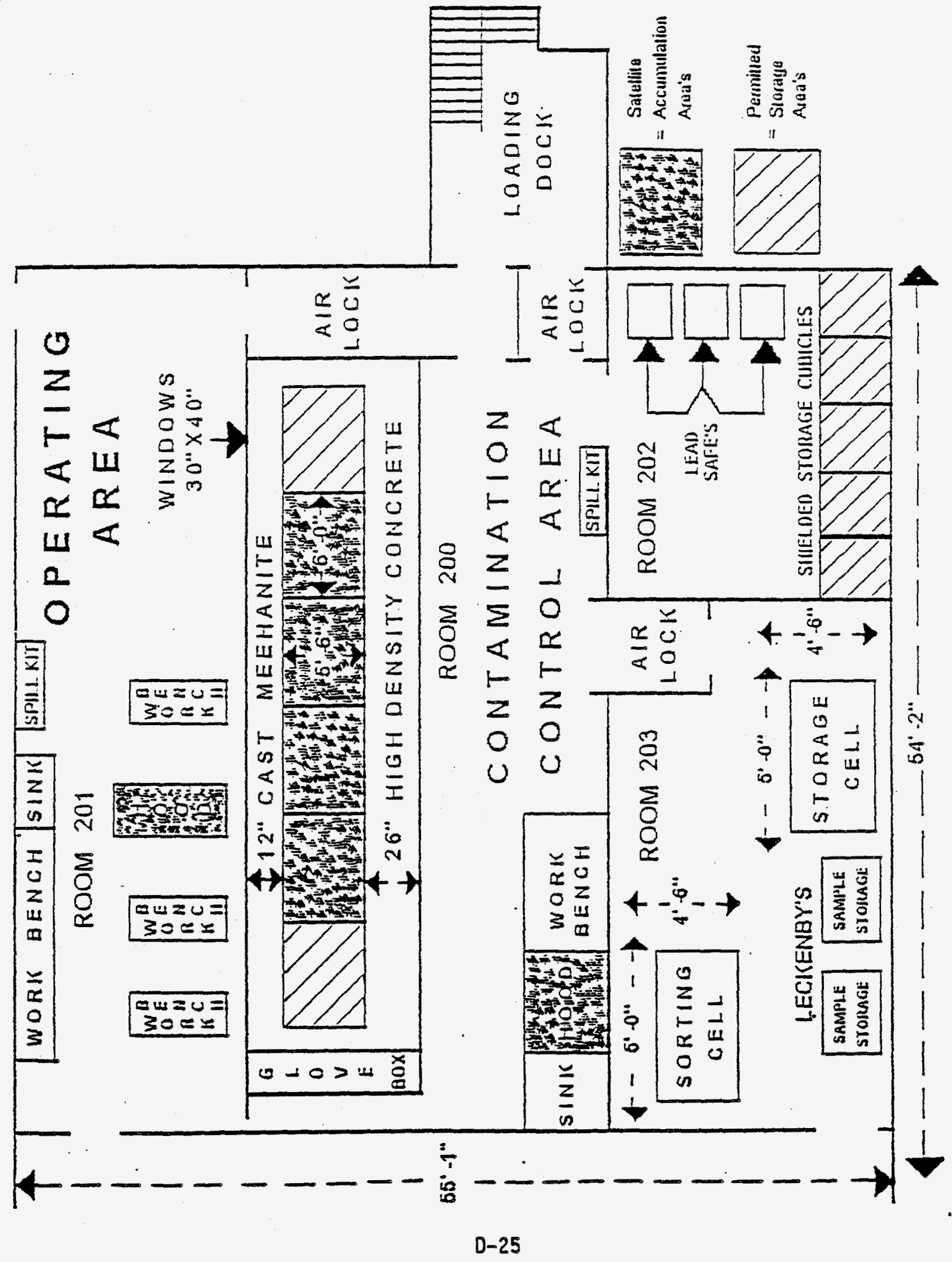


WHC-SD-WM-TA-160
Revision 0

Figure D-11. 327 Building Postirradiation Testing Laboratory.

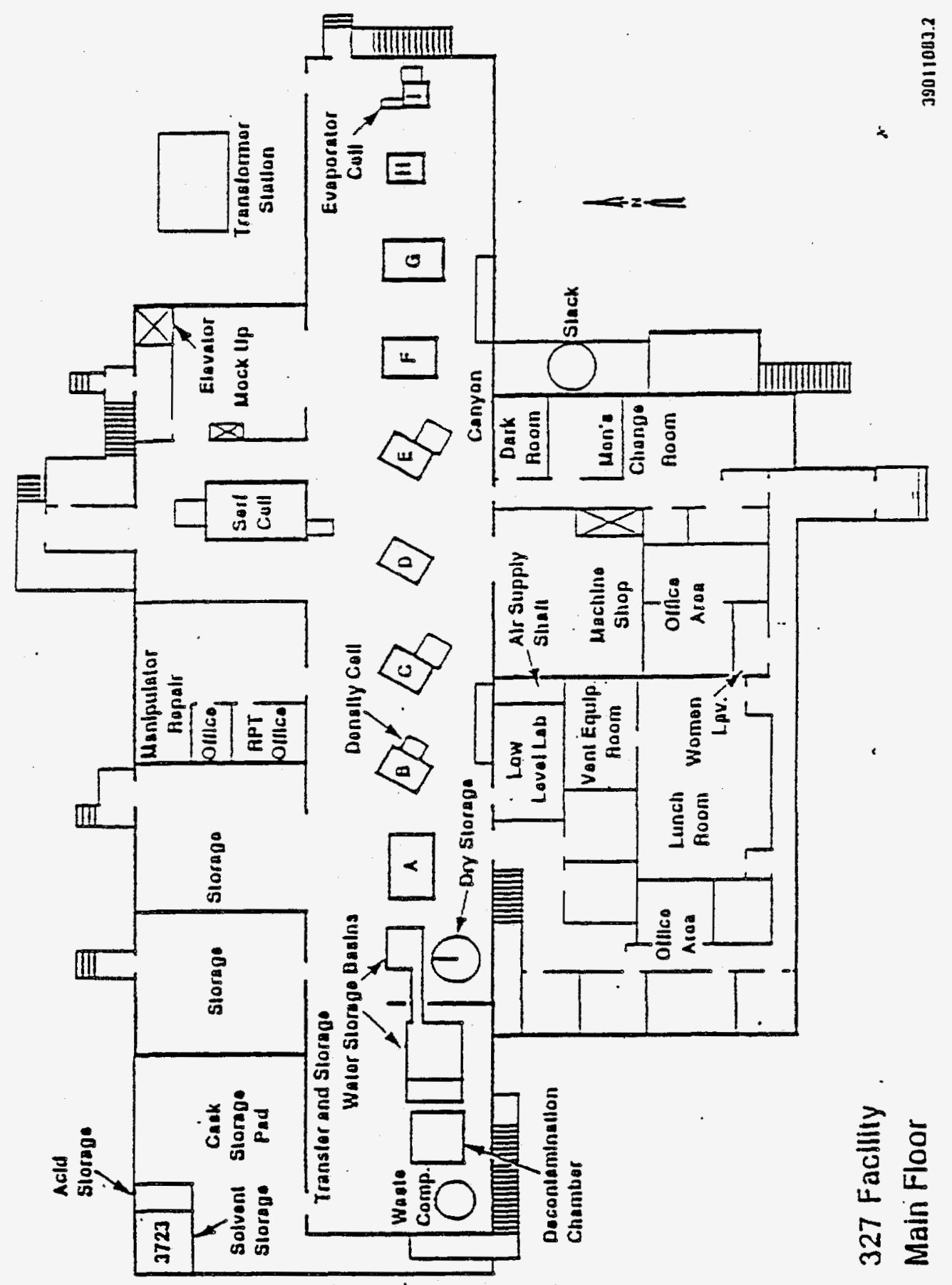




\section{Hot Cell/Site Evaluation}

Site Hanford - WESF

\begin{tabular}{|c|c|c|}
\hline Building number: & HESF & WESF \\
\hline Number of cells: & $B$ and $C$ & $D$ and $E$ \\
\hline \multicolumn{3}{|l|}{ Attribute } \\
\hline Hot cell size & $81 \times 81 \times 12.81 \mathrm{~h}$ & $8^{\circ} \times 18.712 .8 \cdot h$ \\
\hline Equipment access & $81 \times 84$ & $81 \times 16 !$ \\
\hline Service access & $4-4116$ & $8-4^{\prime \prime} \varnothing$ \\
\hline ci loading capability & $<100 K$ & $<100 \mathrm{~K}$ \\
\hline $\begin{array}{l}\text { Cell availability dates: } \\
\text { Start } \\
\text { End }\end{array}$ & $\begin{array}{l}2 / 96 \\
\text { Open }\end{array}$ & $\begin{array}{l}2 / 96 \\
\text { Open }\end{array}$ \\
\hline $\begin{array}{l}\text { Special analytical } \\
\text { equipment in facility* }\end{array}$ & $\begin{array}{l}\text { None in building. } \\
\text { Use } 222 / 325 \text { labs. }\end{array}$ & $\begin{array}{l}\text { None in building. } \\
\text { Use } 222 / 325 \text { labs. }\end{array}$ \\
\hline Hot hoods & No & No \\
\hline $\begin{array}{r}\text { Onsite waste disposal: } \\
\begin{array}{r}\text { Primary } \\
\text { Secondary }\end{array}\end{array}$ & $\begin{array}{l}\text { Yes } \\
\text { Yes }\end{array}$ & $\begin{array}{l}\text { Yes } \\
\text { Yes }\end{array}$ \\
\hline $\begin{array}{l}\text { Estimated cost for } \\
\text { cell cleanout and } \\
\text { commissioning }\end{array}$ & 7.B M for $B, C, D$, and $E$ & \\
\hline
\end{tabular}

NOTE: To convert inches to centimeters, mult iply by 2.54 .

To convert feet to meters, multiply by 0.3048 .

*Special analytical equipment needed with a value of more than $\$ 100 \mathrm{~K}$ and a 4 -month procurement time.

HESF = Waste Encapsulation and Storage facility 
WHC-SD-HM-TA-160

Revision 0

Figure D-12. Waste Encapsulation and Storage Facility Cell Area Arrangement.

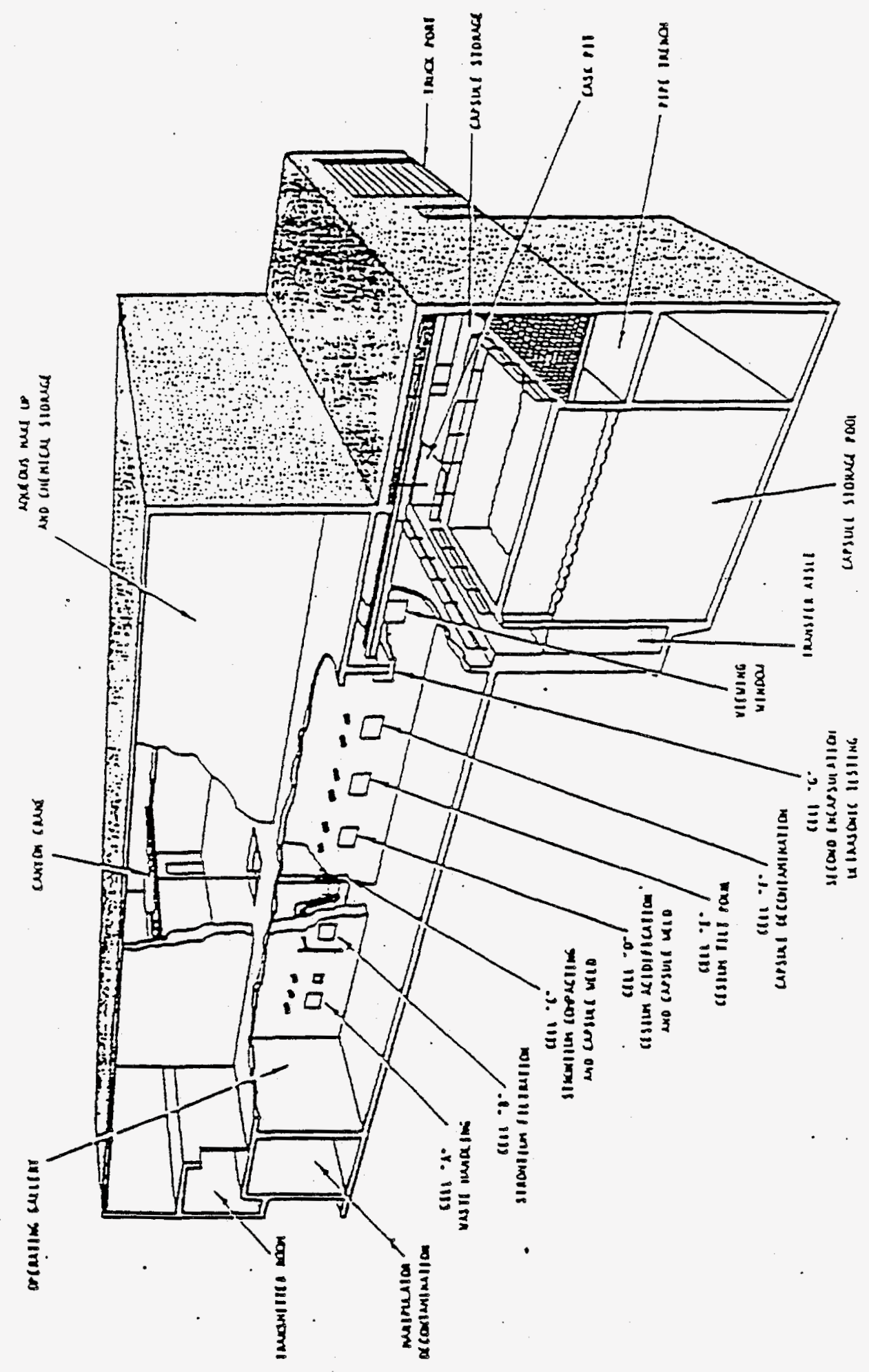


WHC-SD-WM-TA- 160

Revision 0

Figure D-13. Waste Encapsulation and Storage Facility First and Second Floor Plan.

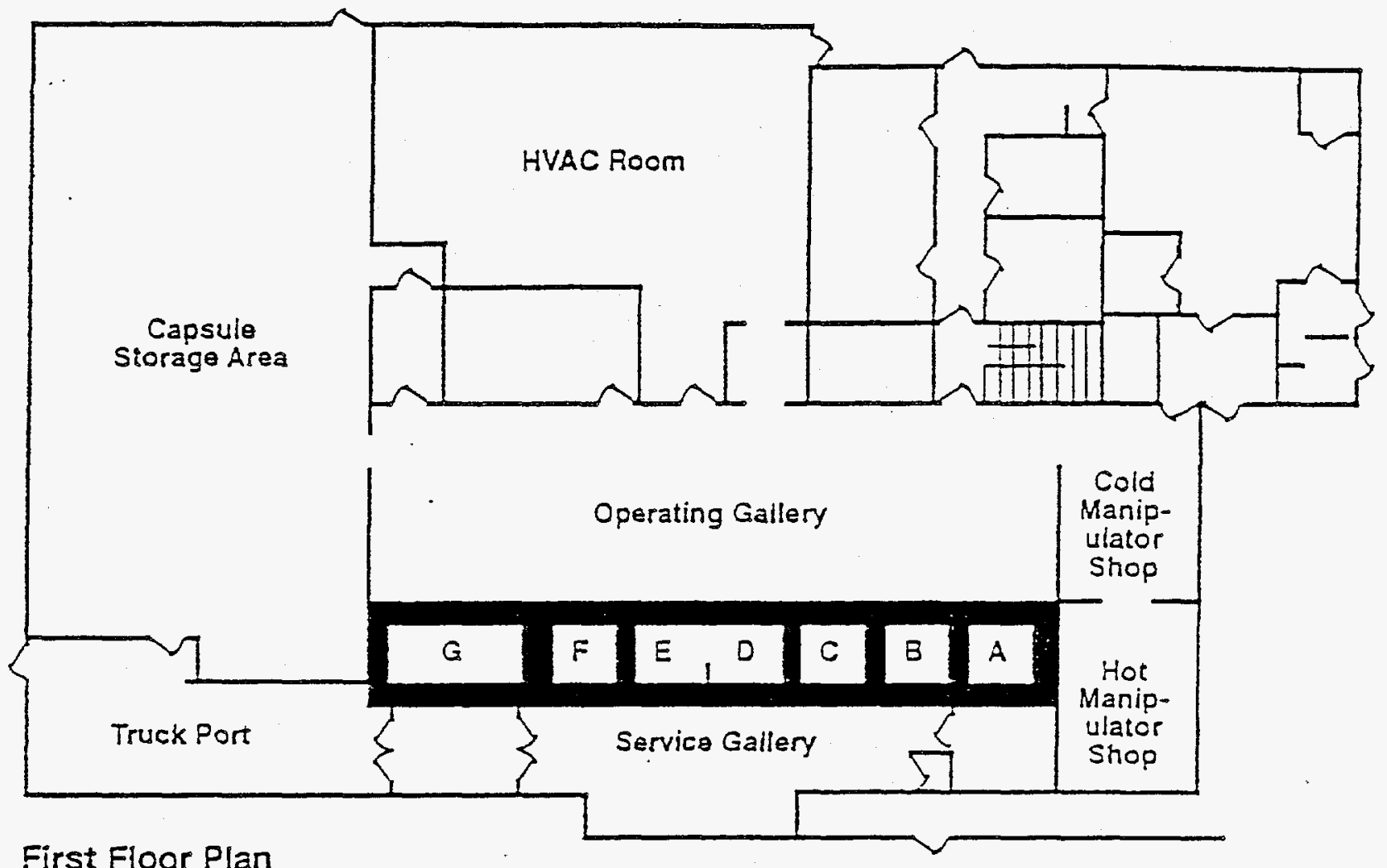

First Floor Plan

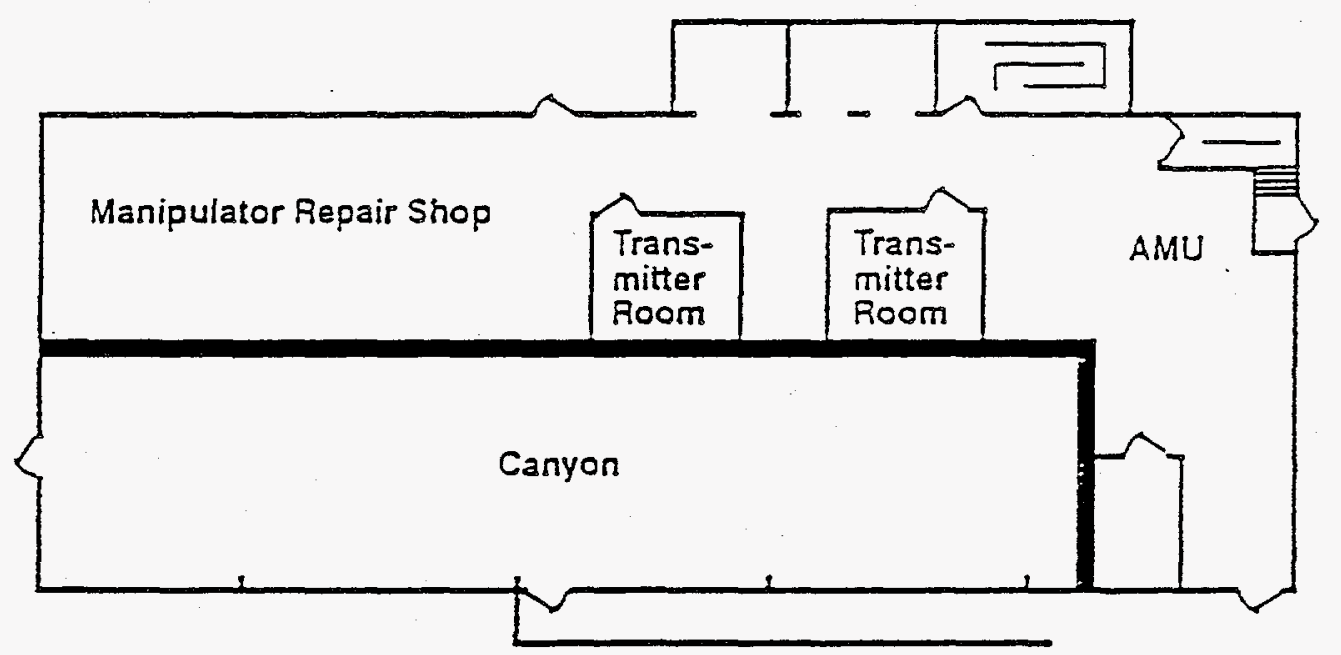

Second Floor Plan 
WHC-SO-WM-TA-160
Revision 0

Figure D-14. Waste Encapsulation and Storage Facility Cell Cross-Sectional View.

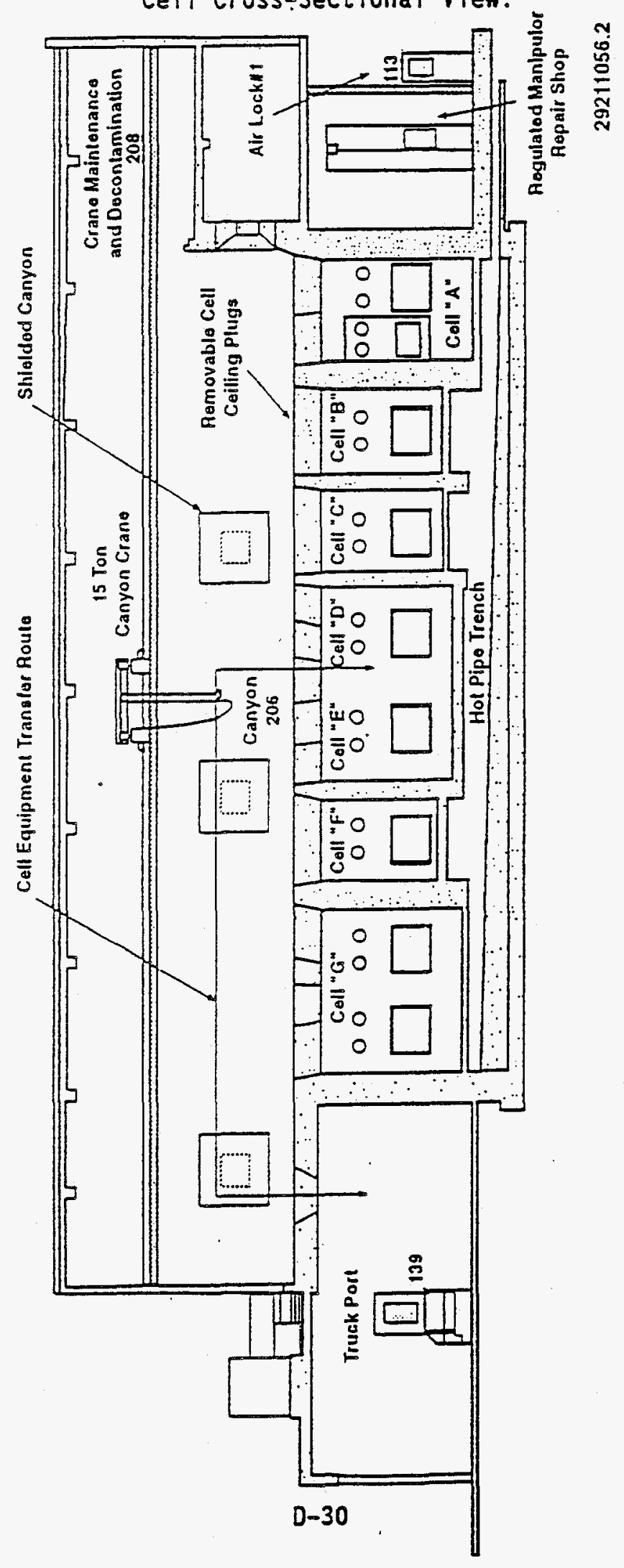




\section{Hot Cell/Site Evaluation}

Site Los Alamos National Laboratory

\begin{tabular}{|c|c|c|}
\hline Building number: & CMR Wing 0 & CMR Wing D \\
\hline Number of cells: & 4 Doubles & 8 singles \\
\hline \multicolumn{3}{|l|}{ Attribute } \\
\hline Hot cell size & $61 \times 14^{\circ}$ & $61 \times 61$ \\
\hline Equipment access & $6511 \times 6511$ & $6511 \times 6511$ \\
\hline Service access & $4 " \phi 8 / \mathrm{cell}$ & $4 " \$ 4 / \mathrm{cell}$ \\
\hline Ci loading capabillity & 60,000 & 60,000 \\
\hline $\begin{array}{l}\text { Cell availability dates: } \\
\begin{array}{r}\text { Start } \\
\text { End }\end{array}\end{array}$ & $\begin{array}{l}10 / 94 \\
10 / 98\end{array}$ & $\begin{array}{l}10 / 94 \\
10 / 98\end{array}$ \\
\hline \multicolumn{3}{|l|}{$\begin{array}{l}\text { Special analytical } \\
\text { equipment in facility* }\end{array}$} \\
\hline Hot hoods & Yes & Yes \\
\hline $\begin{array}{r}\text { Onsite waste disposal: } \\
\begin{array}{r}\text { Primary } \\
\text { Secondary }\end{array}\end{array}$ & $\begin{array}{l}\text { Return to Hanford } \\
\text { Yes }\end{array}$ & $\begin{array}{l}\text { Return to Hanford } \\
\text { Yes }\end{array}$ \\
\hline $\begin{array}{l}\text { Estimated cost for } \\
\text { cell cl eanout and } \\
\text { commissioning }\end{array}$ & so & $\$ 0$ \\
\hline
\end{tabular}

NOTE: To convert inches to centimeters, multiply by 2.54 .

to convert feet to meters, multiply by 0.3048 .

*Special analytical equipment needed with a value of more than $\$ 100 \mathrm{~K}$ and a 4 -month procurement time.

CMR = Central monitoring room 
WHC-SD-WM-TA-160

Revision 0

Figure D-15. Los Alamos National Laboratory MST-5 Hot Cell Facility.

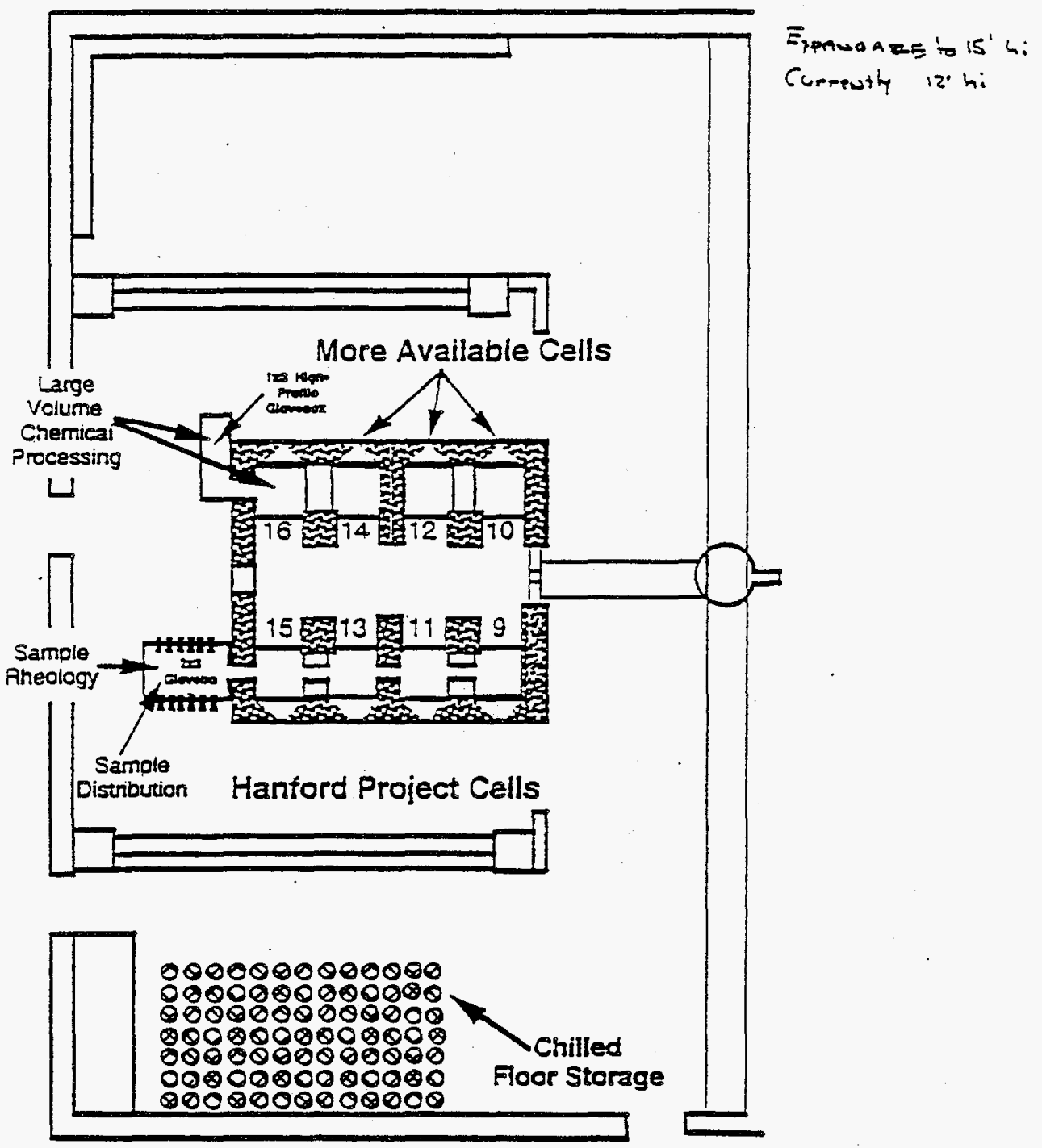




\section{Hot Cell/Site Evaluation}

Site Hanford - FMEF

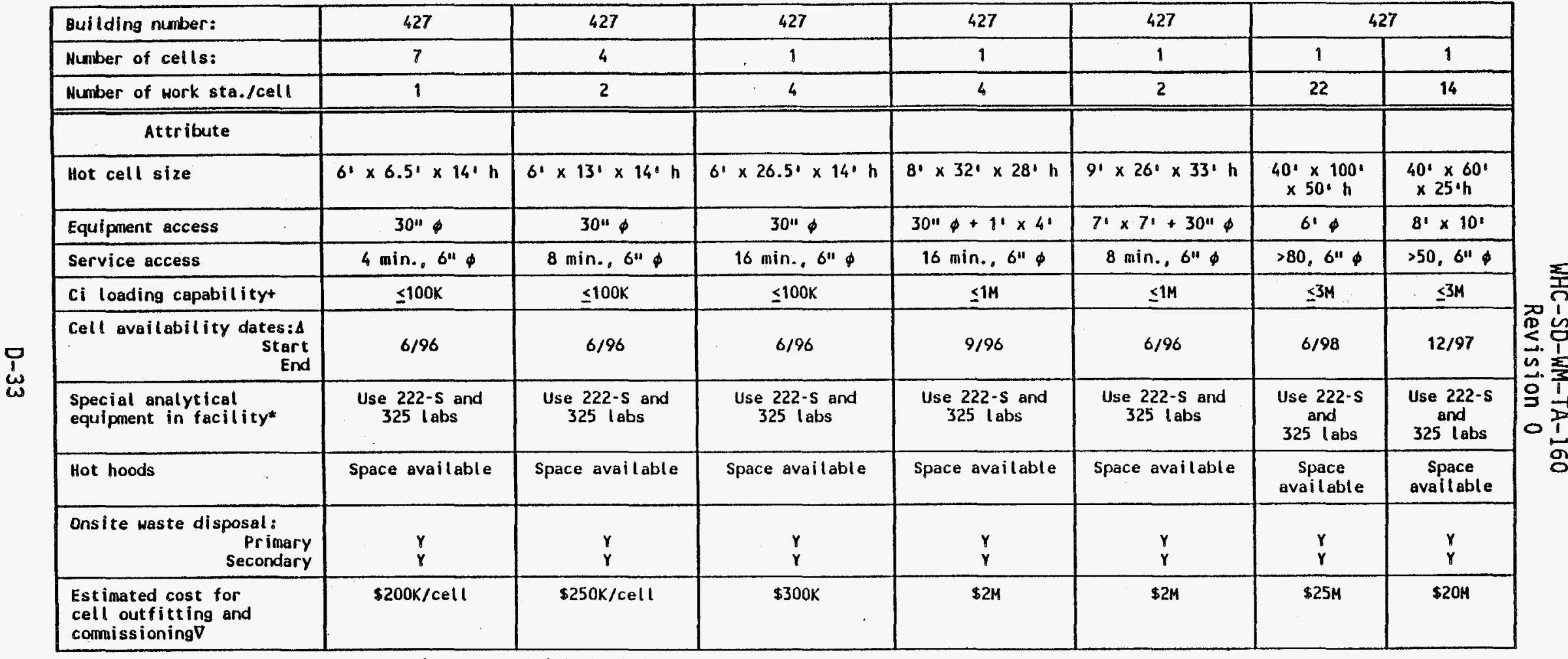

NOTE: To convert inches to centimeters, multiply by 2.54 .

to convert feet to meters, multiply by 0.3048 .

*Special analytical equipment needed with a value of more than $\$ 100 \mathrm{~K}$ and a 4 -month procurement time.

+Estimated based on equivalent cells - must be confirmed before using data.

EEstimated earliest date outfitted cells could be available for test equipment installation.

VAdded costs for facility support expected dependent on cell conbination selected.

FMEF = Fuels and Materials Examination Facility 


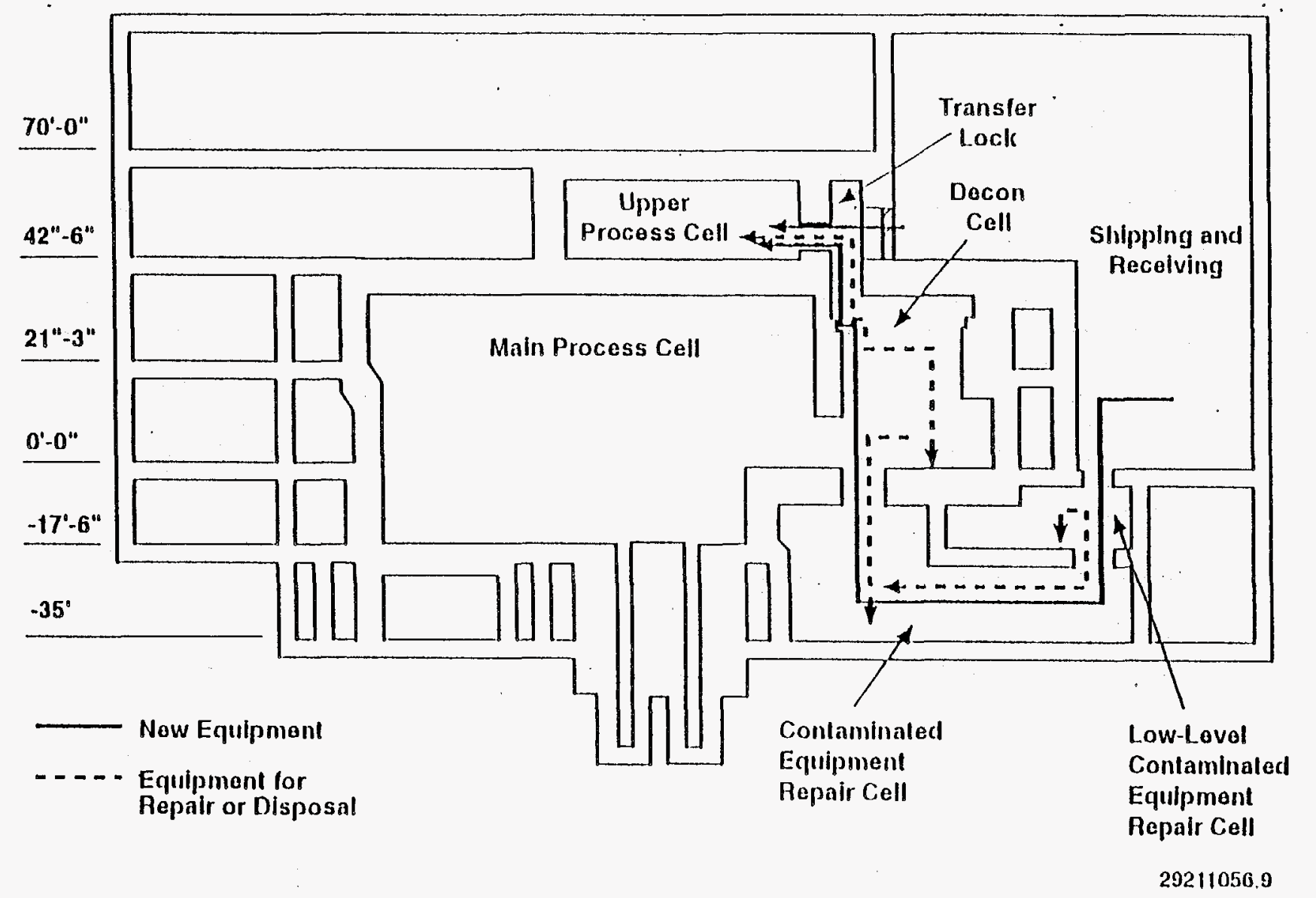


Figure D-17. Fuels and Materials Examination Facility 42-ft 6-in. Level.
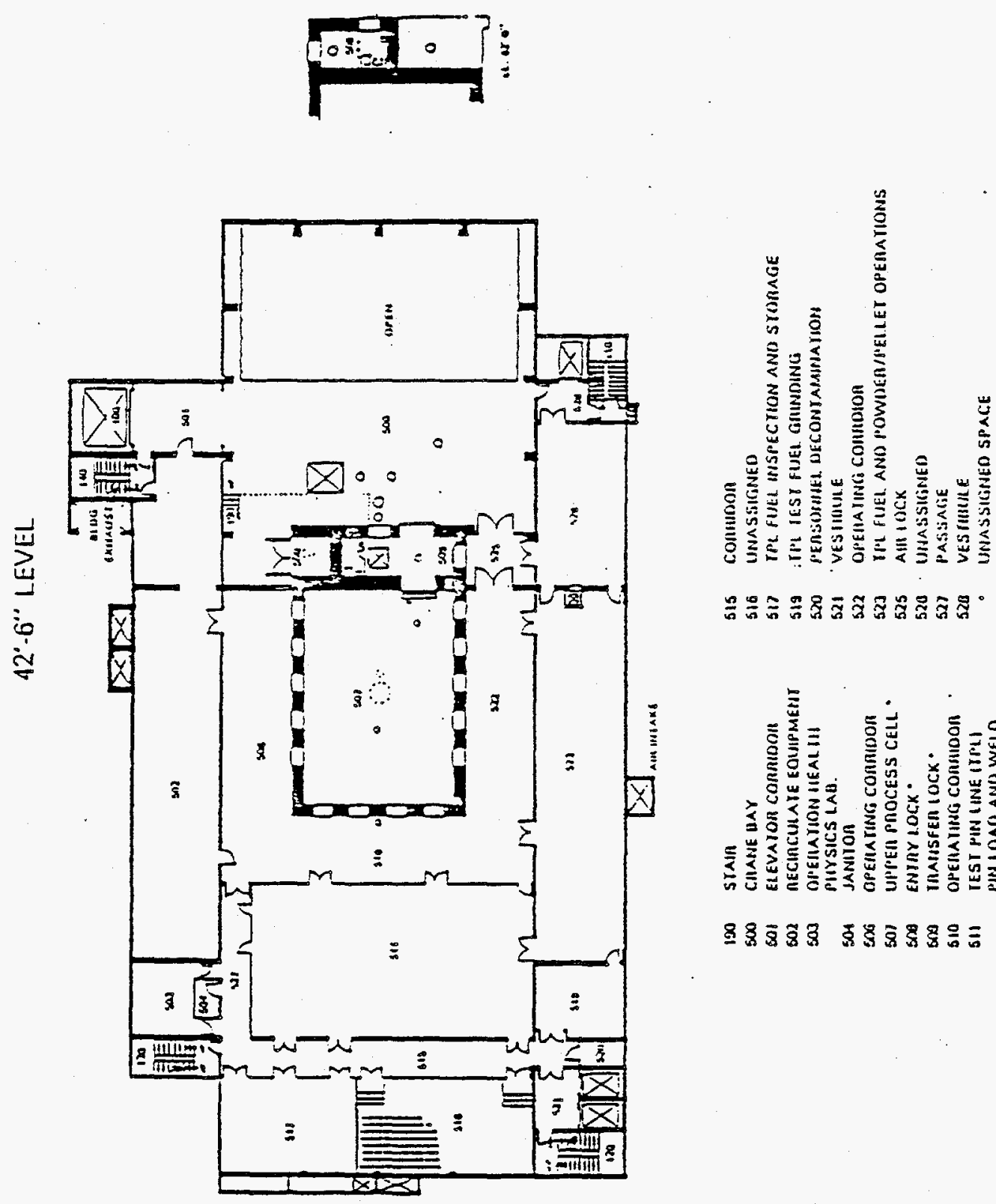

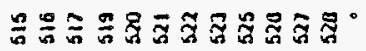

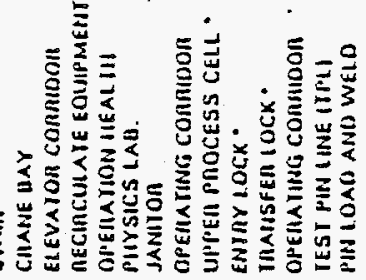

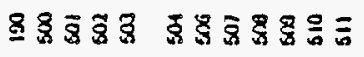


WHC-SD-WM-TA-160

Revision 0

Figure D-18. Fuels and Materials Examination Facility Building Main Floor Plan.

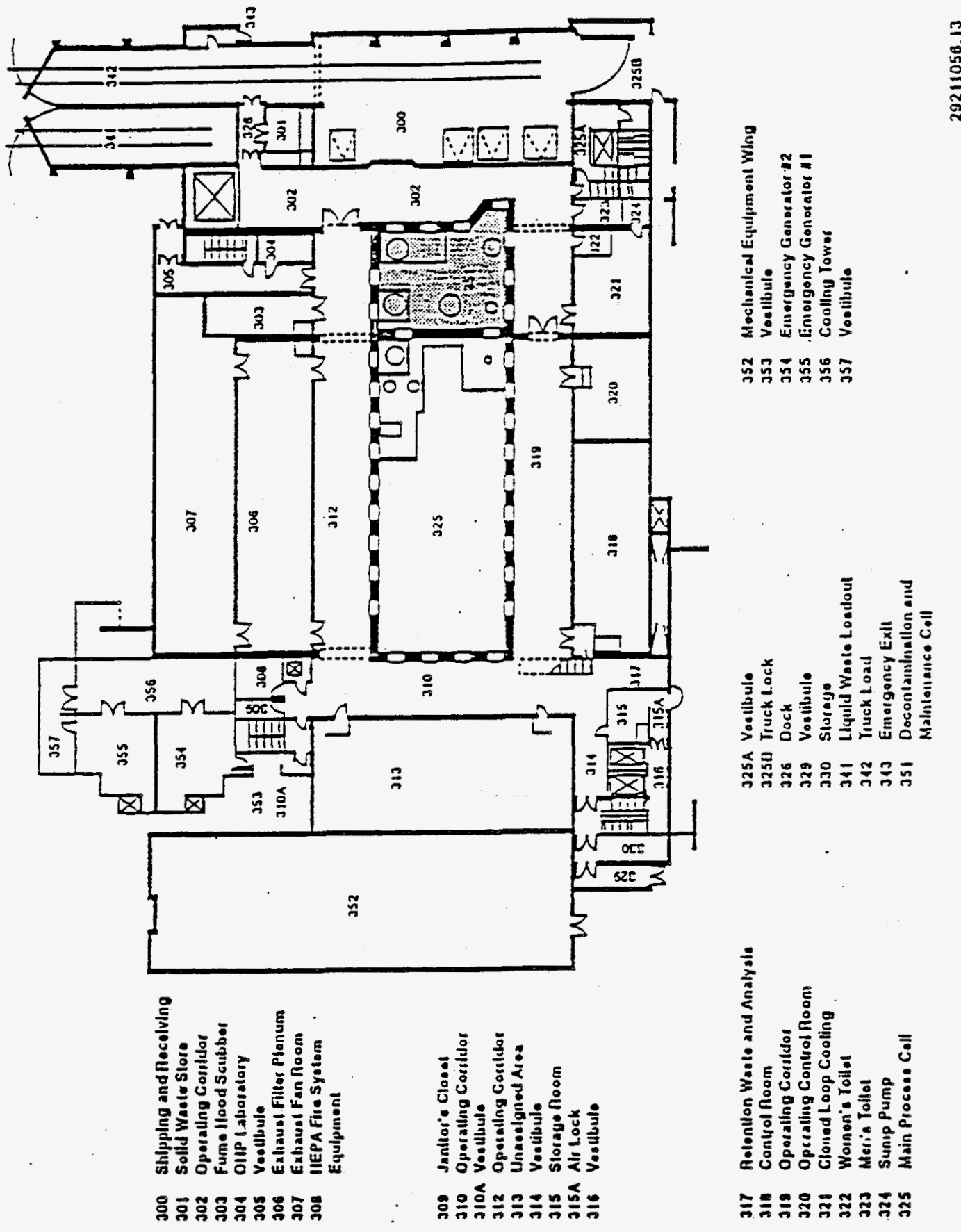


WHC-SO-WM-TA-160

Revision 0

Figure D-19. Fuels and Materials Examination Facility 21-ft 3-in. Level.

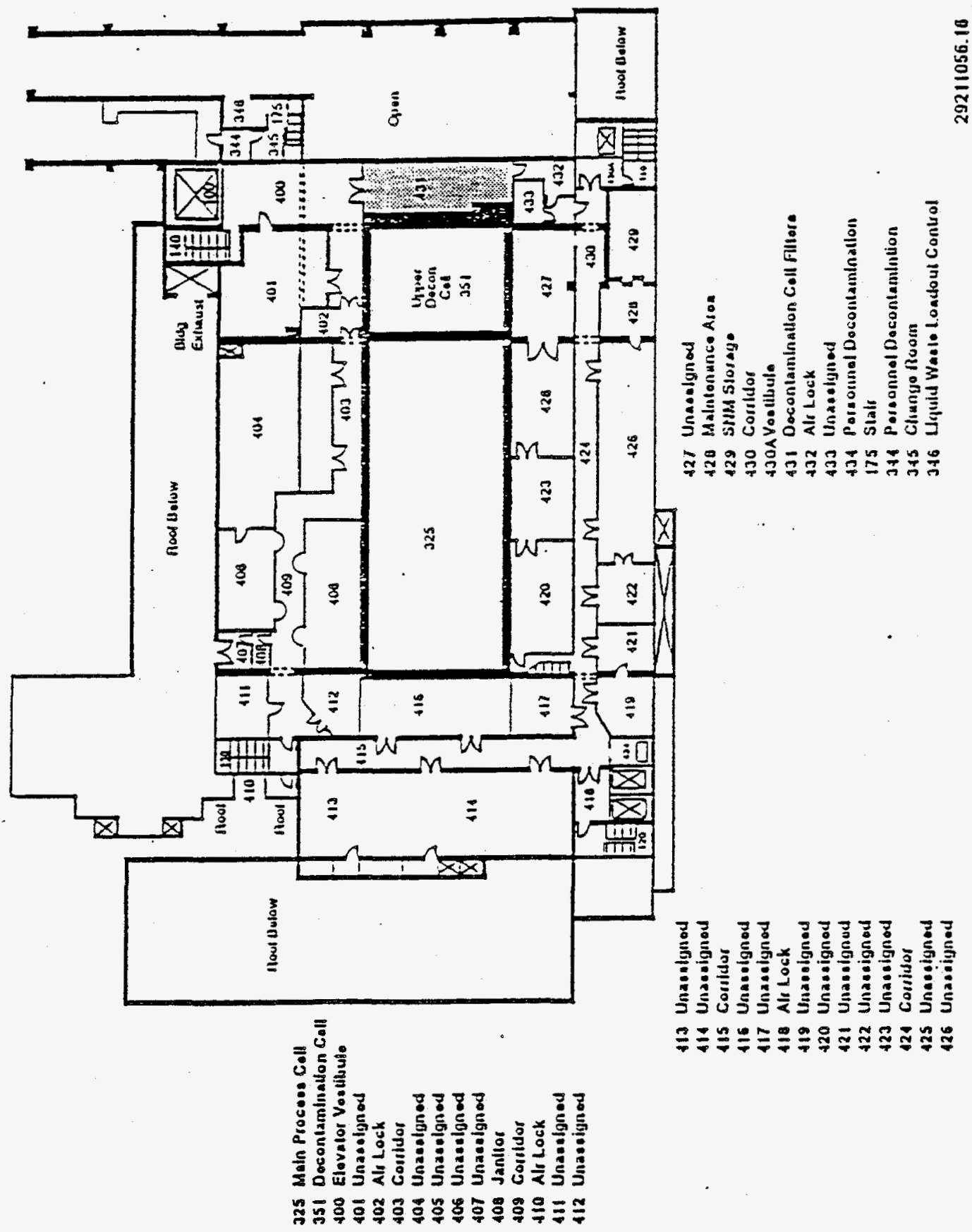


WHC-SD-WM-TA- 160

Revision 0

Figure D-20. Fueis and Materials Examination Facility (-)35-ft 0 -in. Level.

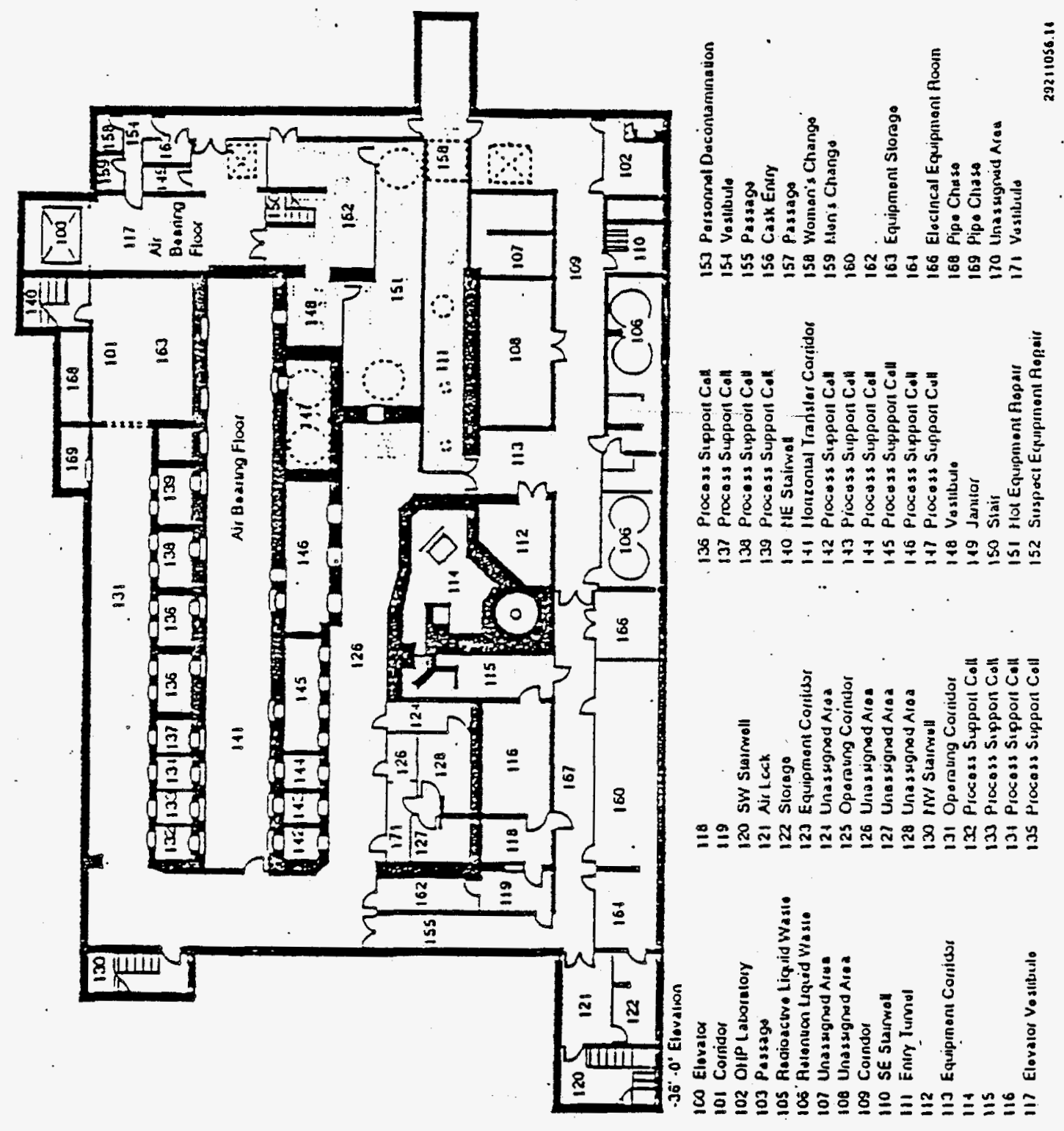




\section{Hot Cell/Site Evaluation}

\section{Site Idaho Falls ANL-W}

\begin{tabular}{|c|c|c|c|}
\hline Buil ding number: & Analytical Lab & HFEF & FCF \\
\hline Number of cells: & 1 & $2-3$ stations & $2-3$ stations \\
\hline \multicolumn{4}{|l|}{ Attribute } \\
\hline Hot cell size & $51 x+6.51$ & $20^{\circ} \times 30^{\prime}$ & $20^{\circ} \times 25^{\circ}$ \\
\hline Equipment access & $31 \times 76$ & Very large & Very large \\
\hline Service access & Yes & Yes & Yes \\
\hline ci loading capability & $2,000 \max$. & $>2,000$ & $>2,000$ \\
\hline $\begin{array}{r}\text { Cell availability dates: } \\
\text { Start } \\
\text {. End }\end{array}$ & $\begin{array}{l}3 / 95 \\
\text { Open }\end{array}$ & $\begin{array}{c}1 / 1 / 95 \\
\text { Open }\end{array}$ & $\begin{array}{c}1 / 1 / 95 \\
\text { Open }\end{array}$ \\
\hline \multicolumn{4}{|l|}{$\begin{array}{l}\text { Special analytical } \\
\text { equipment in facility*t }\end{array}$} \\
\hline Hot hoods & Yes & Use Analytical Lab & Use Analytical Lab \\
\hline $\begin{array}{r}\text { Onsite waste disposal: } \\
\text { Primary } \\
\text { Secondary }\end{array}$ & $\begin{array}{l}\text { Ship to Hanford } \\
\text { Yes }\end{array}$ & $\begin{array}{l}\text { Ship to Hanford } \\
\text { Yes }\end{array}$ & $\begin{array}{c}\text { Ship to llanford } \\
\text { Yes }\end{array}$ \\
\hline $\begin{array}{l}\text { Estimated cost for } \\
\text { cell cleanout and } \\
\text { commissioning }\end{array}$ & Clean & clean & clean \\
\hline
\end{tabular}

NOTE: To convert inches to centimeters, mult tiply by 2.54 .

To convert feet to meters, multiply by 0.3048 .

*Special analytical equipment needed with a value of more than $\$ 100 \mathrm{~K}$ and a 4 -month procurement time.

+Analytical equipment available includes XAS and in-cell ICP, MS, IR, TEM, and SEM.

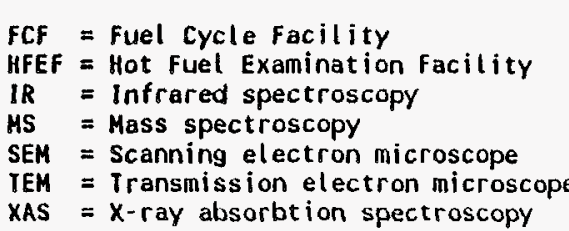


WHC-SD-WM-TA-160

Revision 0

Figure D-21. ANL-W Analytical Laboratory Cells - Plan View.

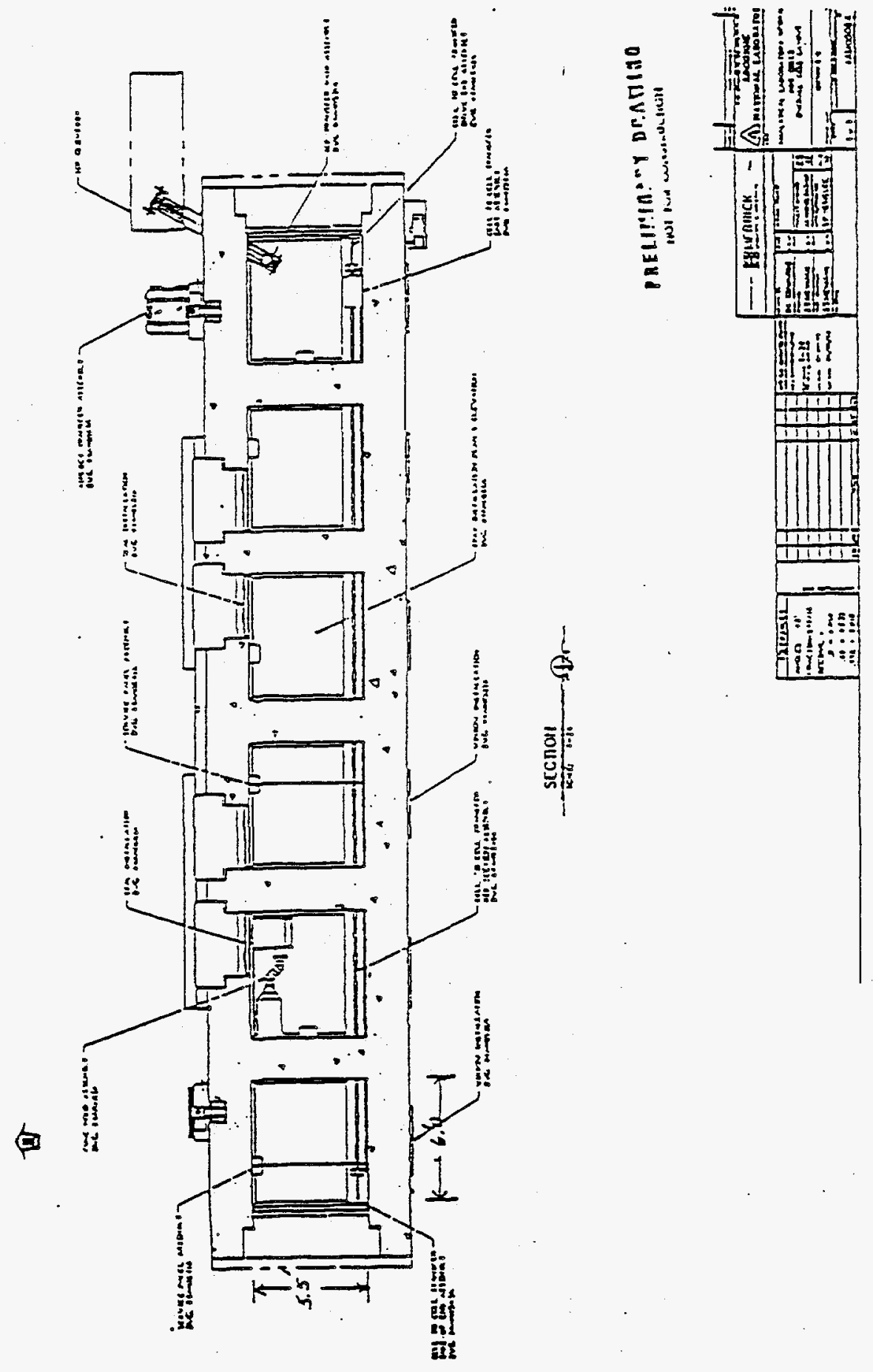


WHC-SD-WM-TA-160

Revision 0

Figure D-22. ANL-W Analytical Laboratory Cell - Elevation View.

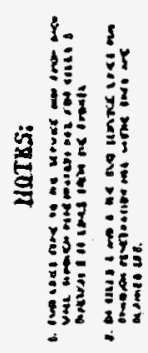
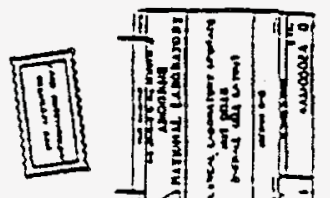

ती

1.

x 1 in

章

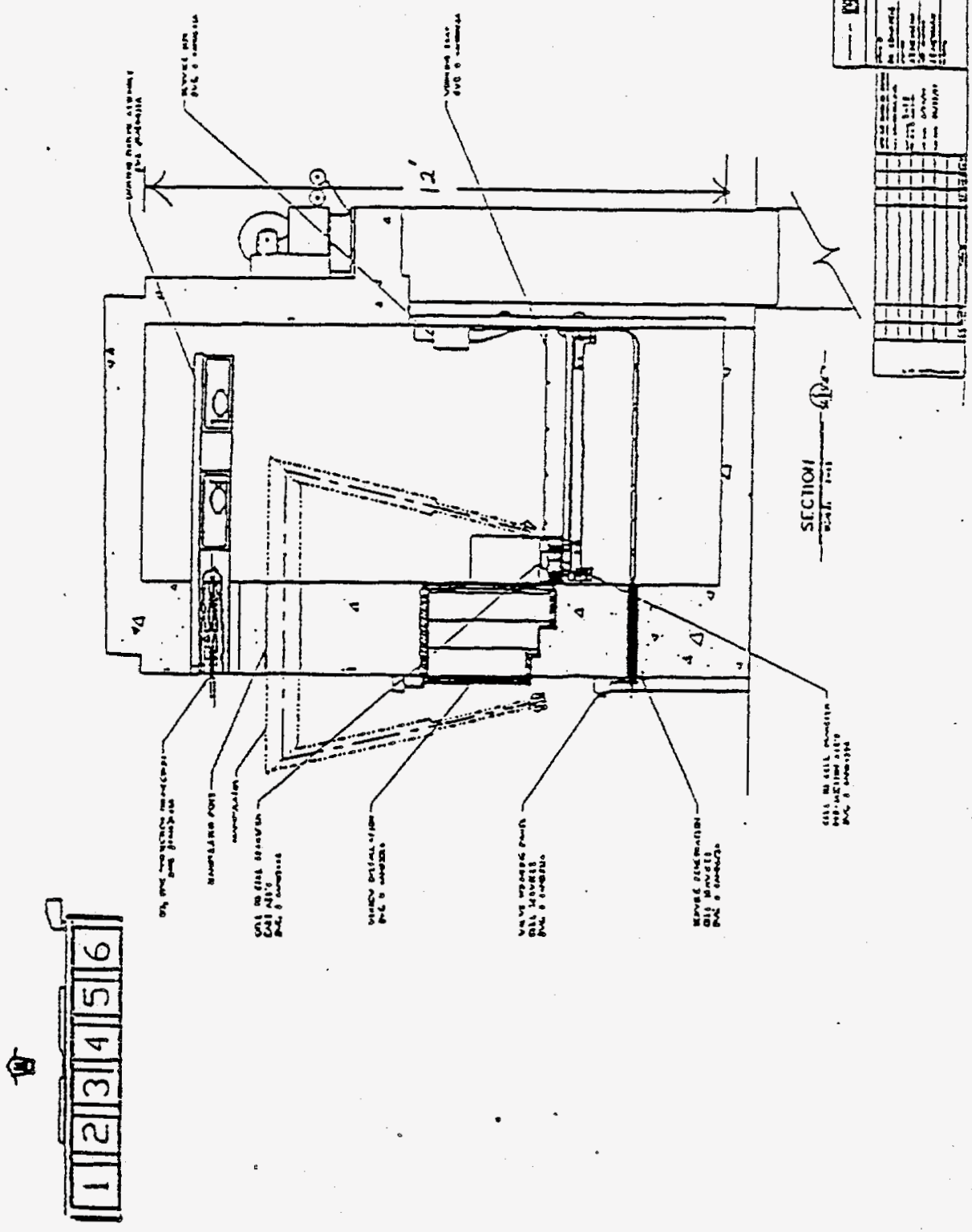


WHC-SD-WM-TA-160

Revision 0

Figure D-23. Hot Fuel Examination Facility Argonne National Laboratory-W.

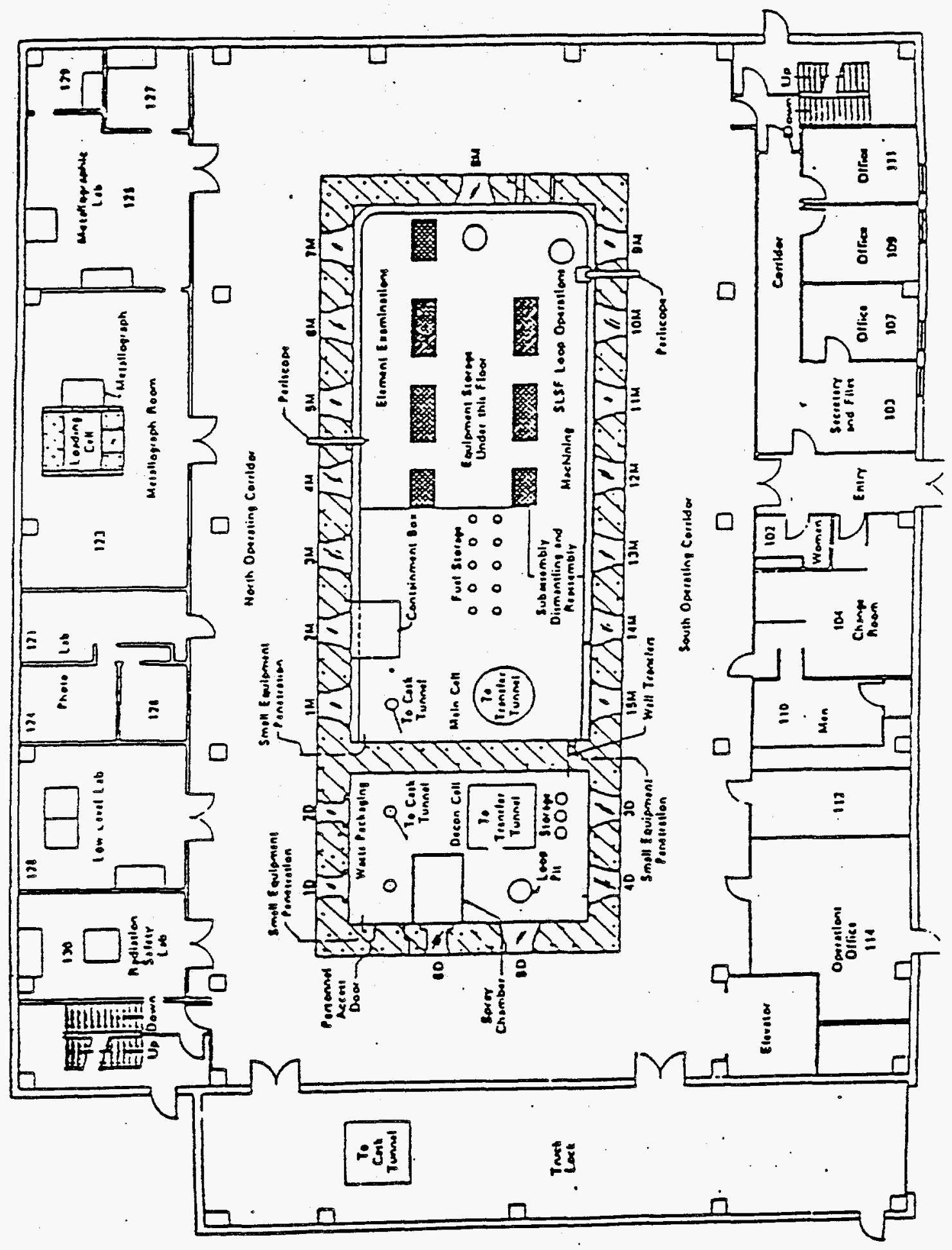


Figure D-24. Fuel Cycle Facility Argonne National Laboratory-W.

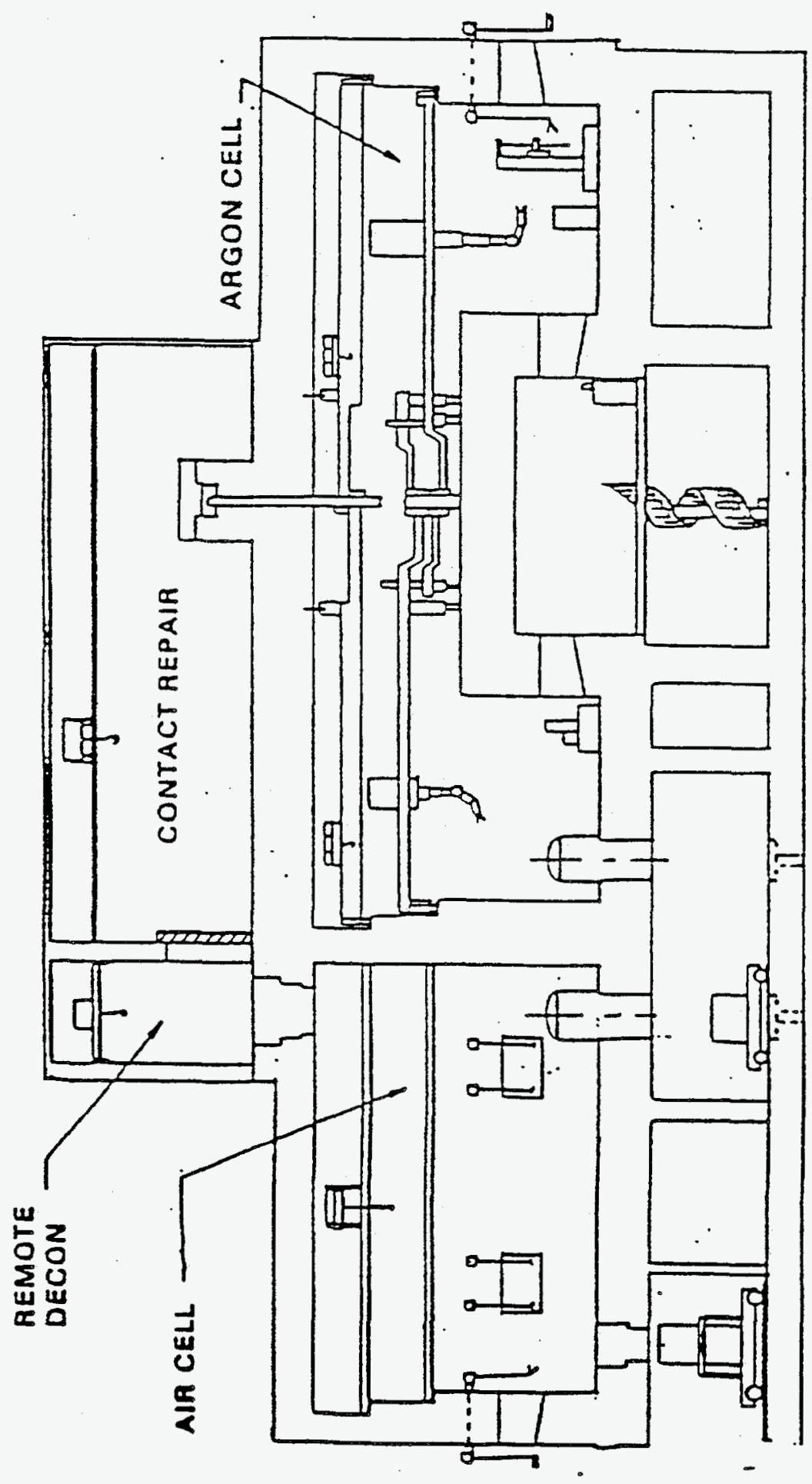




\section{Hot Cell/Site Evaluation}

Site Idaho Falls - LITCO

\begin{tabular}{|c|c|c|c|}
\hline Building number: & CPP-G01 & CPP-G84 & CPP-G66 \\
\hline Number of cells: & 3 & 1 & 1 \\
\hline \multicolumn{4}{|l|}{ Attribute } \\
\hline Hot cell size & $2.5^{\circ} \times 6^{1}$ & $20^{\prime} \times 50^{\prime}$ & $100^{\prime} \times 20^{\prime}$ \\
\hline Equipment access & $2.51 \times 31$ & $41 \times 61$ & $141 \times 64$ \\
\hline Service access & Yes & Yes & Yes \\
\hline ci loading capability & $\begin{array}{l}5^{\circ} \text { concrete } \\
>2,000\end{array}$ & $\begin{array}{l}\text { 3' concrete } \\
\text { unknown }\end{array}$ & $>2,000$ \\
\hline $\begin{array}{r}\text { Cell availability dates: } \\
\text { Start } \\
\text { End }\end{array}$ & $\begin{array}{l}1 / 95 \\
\text { Open }\end{array}$ & $\begin{array}{l}7 / 95 \\
\text { Open }\end{array}$ & $\begin{array}{c}1 / 95 \\
1 / 97 ?\end{array}$ \\
\hline \multicolumn{4}{|l|}{$\begin{array}{l}\text { Special anslytical } \\
\text { equipment in facility*t }\end{array}$} \\
\hline Hot hoods & No & No & Ho \\
\hline $\begin{array}{r}\text { Onsite maste disposal: } \\
\text { Primary } \\
\text { Secondary }\end{array}$ & $\begin{array}{l}\text { Ship to Hanford } \\
\text { Yes }\end{array}$ & $\begin{array}{l}\text { Ship to Hanford } \\
\text { Yes }\end{array}$ & $\begin{array}{l}\text { Ship to Hanford } \\
\text { Yes }\end{array}$ \\
\hline $\begin{array}{l}\text { Estimated cost for } \\
\text { cell cleanout and } \\
\text { commissioning }\end{array}$ & Clean & $\begin{array}{l}\text { LIrco would pay if } \\
\text { any }\end{array}$ & None expected \\
\hline
\end{tabular}

NOTE: To convert inches to cent imeters, mult tiply by 2.54 . To convert feet to meters, maltiply by 0.3048 .

*Special analytical equipment needed with a value of more than $\$ 100 \mathrm{~K}$ and a 4 -month procurement time.

+Analytical equipment available - in-cell XAS in CPP-G84 other work done at ANL-W Lab.

LITCO = Lockheed Idaho Technology Company

$X A S=X$-ray absorbtion spectroscopy 


\section{Hot Cell/Site Evaluation}

Site Oak Ridge National Laboratory

\begin{tabular}{|c|c|c|c|c|}
\hline Building number: & 4501 & 2026 & 3517 & 3047 \\
\hline Number of cells: & $2(B$ and $D)$ & 6 & 5 & 4 \\
\hline \multicolumn{5}{|l|}{ Attribute } \\
\hline Hot cell size & $8^{\circ} \times 6^{\prime} \times 20^{\prime} \mathrm{h}$ & $60 \times 7 \cdot 11 \cdot \mathrm{h}$ & $\begin{array}{l}2-71 \times 81 \times 110 \mathrm{~h} \\
1=131 \times 81 \times 110 \mathrm{~h} \\
1=91 \times 101 \times 160 \mathrm{~h}\end{array}$ & $\begin{array}{l}2-61 \times 81 \times 131 \mathrm{~h} \\
2-86 \times 80 \times 18, h\end{array}$ \\
\hline Equipment access & $-30^{\prime \prime} \times 30^{\prime \prime}$ & $-71 \times 5^{\prime}$ & $\begin{array}{l}1-201 \times 81 \times 111+ \\
\text { full cell ceilling }\end{array}$ & $\begin{array}{l}2-60 \times 81+ \\
2-81 \times 81+\end{array}$ \\
\hline Service access & $6^{\prime \prime} \phi 4 / \mathrm{cell}$ & $4 " \phi$ & $6 " \phi$ and $10^{\prime \prime} \phi$ & $4 " \phi$ and $6 " \phi$ \\
\hline Ci loading capability & $\leq 20,000$ & $\leq 20,000$ & $\leq 40,000$ & $\leq 20,000$ \\
\hline $\begin{array}{r}\text { Cell availability dates: } \\
\text { Start } \\
\text { End }\end{array}$ & $\begin{array}{ll}8^{\star \star} & 0 \\
4 / 95 & 6 / 95 \\
\text { open } & \text { Open }\end{array}$ & $\begin{array}{l}9 / 96 \\
\text { Open }\end{array}$ & $\begin{array}{r}1 / 96 \\
12 / 98\end{array}$ & $\begin{array}{l}1 / 95 \\
\text { Open }\end{array}$ \\
\hline $\begin{array}{l}\text { Special analytical } \\
\text { equipment in facility }\end{array}$ & $\begin{array}{l}\text { Bldg. } 4501 \text { anal. equip. } \\
\text { (gamma, ICP-AES, ICP-MS, } \\
\text { SEM. IEM) }\end{array}$ & $\begin{array}{c}\text { Bldg. } 2026 \text { anal. equip. } \\
\text { (gamma, sr and IC, particle } \\
\text { size roc ICP-AES, ICP-MS, } \\
\text { ion chro.) }\end{array}$ & $\begin{array}{l}\text { None, this building use } \\
\text { adjacent labs } \\
\text { Bldg: 2026, } 4501\end{array}$ & $\begin{array}{c}\text { None, this building uses } \\
\text { adjacent labs. } \\
\text { Bldg. 2026, } 4501\end{array}$ \\
\hline Hot hoods & Yes & Yes & No & No \\
\hline $\begin{array}{r}\text { Onsite waste disposal: } \\
\text { Primary } \\
\text { Secondary }\end{array}$ & $\begin{array}{l}\text { Yes - onsite } \\
\text { res - onsite }\end{array}$ & $\begin{array}{l}\text { Yes } \\
\text { Yes }\end{array}$ & $\begin{array}{l}\text { Yes } \\
\text { Yes }\end{array}$ & $\begin{array}{l}\text { Yes } \\
\text { Yes }\end{array}$ \\
\hline $\begin{array}{l}\text { Estimated cost for } \\
\text { cell cleanout and } \\
\text { commissioning }\end{array}$ & $\begin{array}{cc}B & D \\
\$ 250 K & \$ 350 K\end{array}$ & NA & $\$ 5 M$ & $\$ 0$ \\
\hline
\end{tabular}

NorE: To convert inches to centimeters, multiply by 2.54 .

To convert feet to meters, multiply by 0.3048 .

*Special analytical equipment needed with a value of more than $\$ 100 \mathrm{~K}$ and a 4 -month procurement time.

**Could use part of A cell until 8 cell $c / 0$ is completed.

\section{tceiling}

ICP-AES = Inductively coupled plasma - atomic emission spectrometer

ICP-HS = Inductively coupled plasma - mass spectrometer

SEM = Scanning electron microscope

TEM = Transmission el ectron microscope

IOC = rotal organic carbon 
WHC-SD-WM-TA-160

Revision 0

Figure D-25. Building 4501 - First Floor Plan

(Cross-Hatched Areas Radiation Zones).

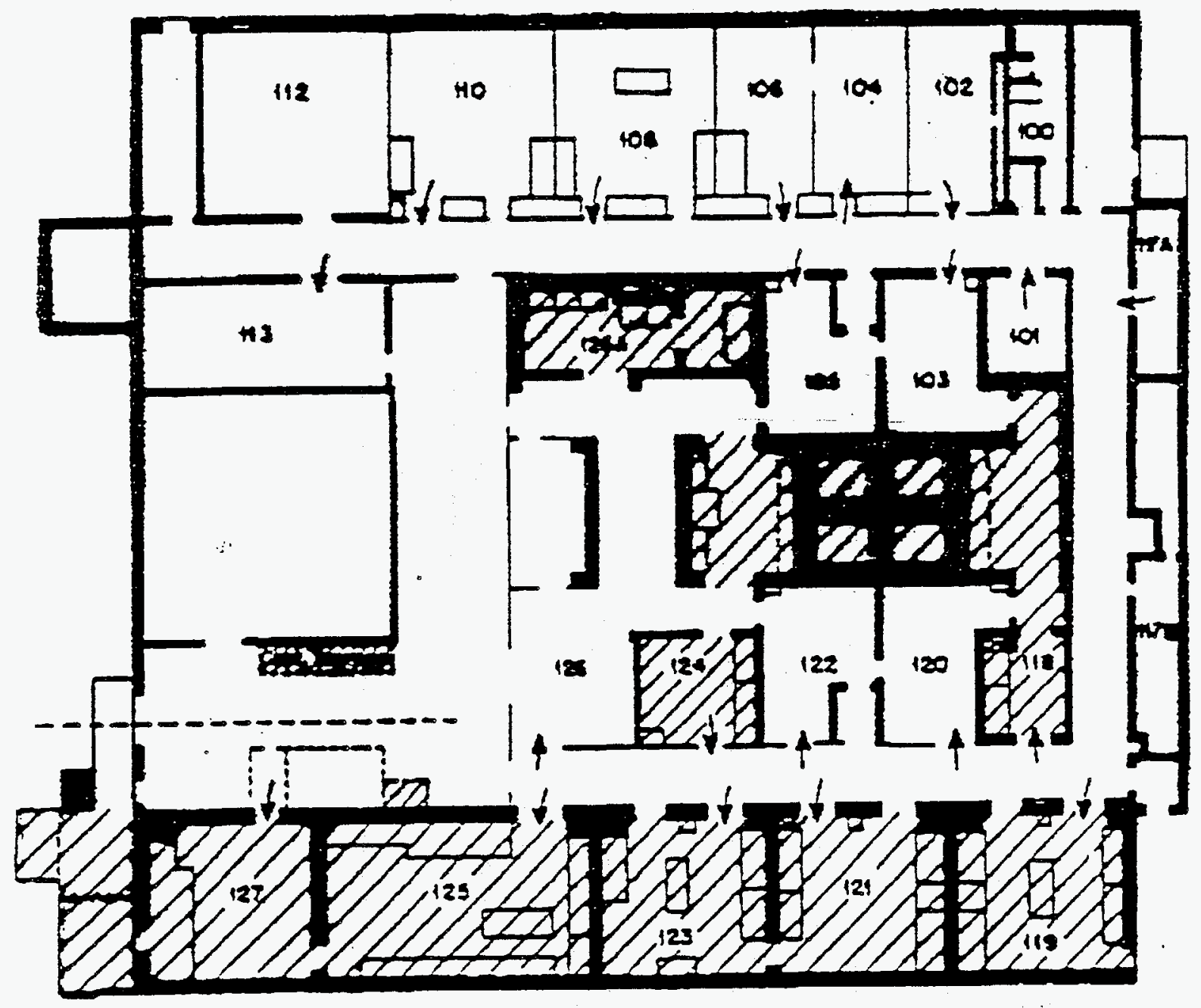


Figure D-26. Building 2026 - Plan of Oak Ridge National Laboratory High-Radiation-Level Analytical Laboratory (First Floor).

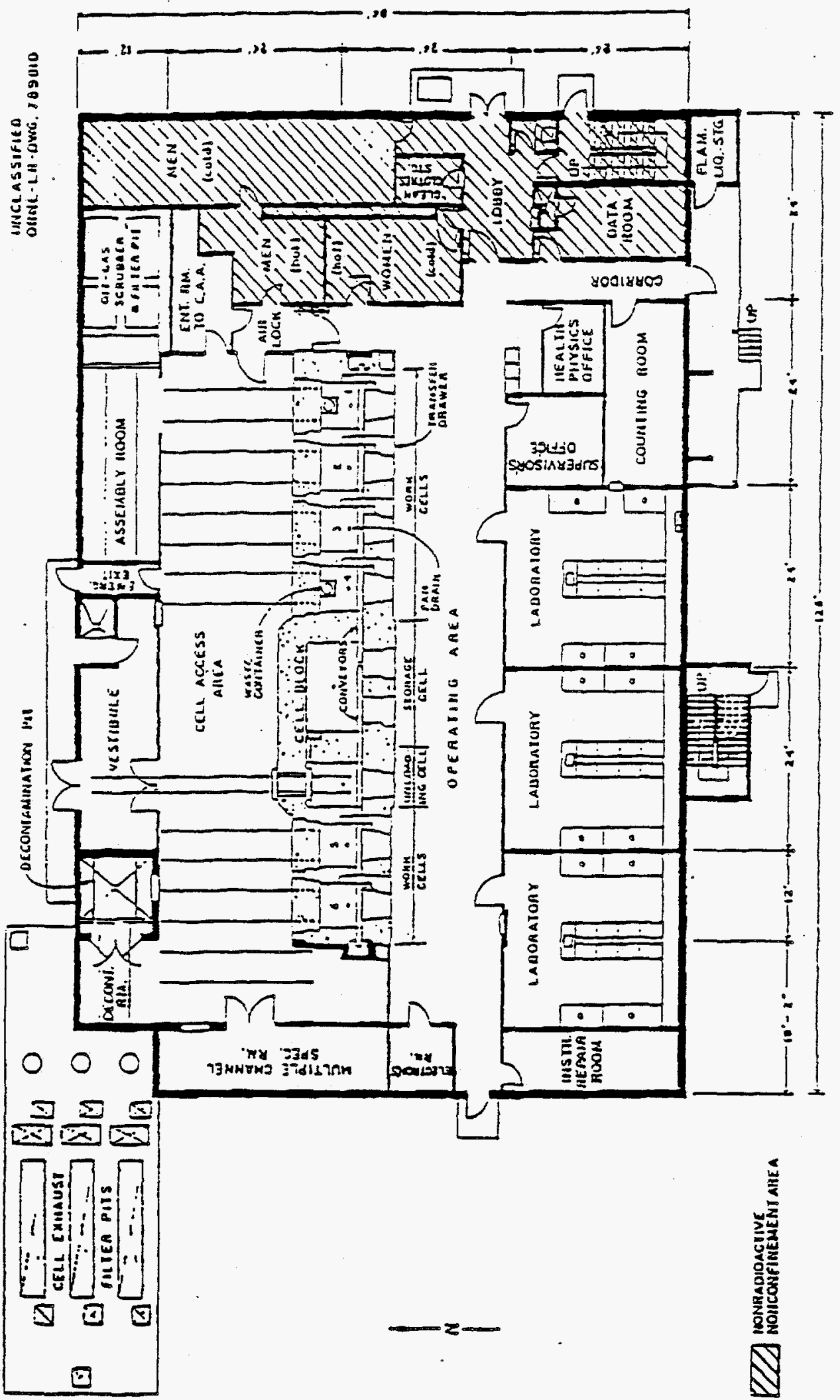


WHC-SD-WM-TA-160

Revision 0

Figure 0-27. Building 2026 - Typical Work Cell Cross-Section.
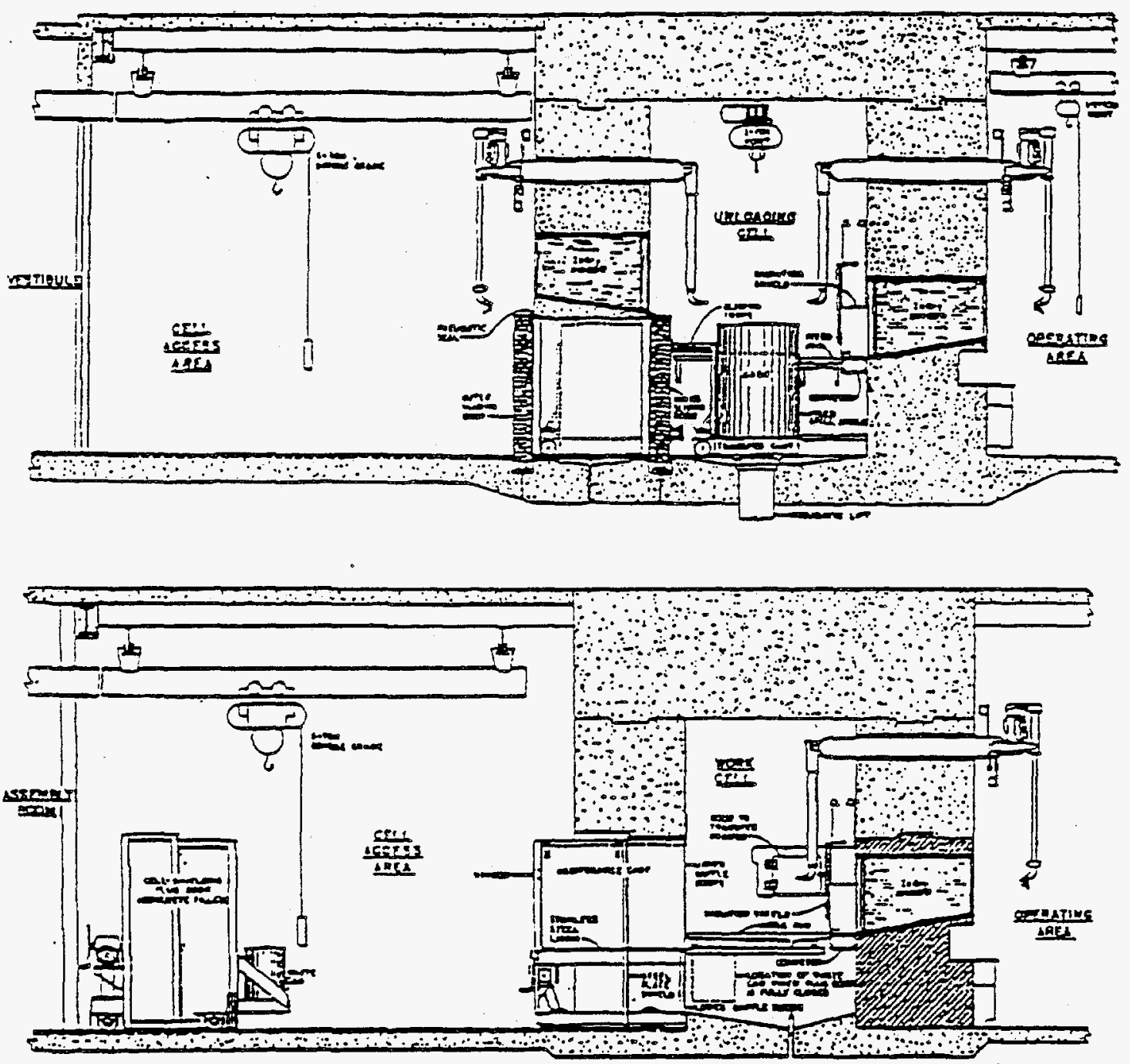
WHC-SD-WM-TA- 160

Revision 0

Figure D-28. Building 3517 Arrangement.

0
0
0
1
0
0
0
3
0
$\frac{1}{2}$
0
0

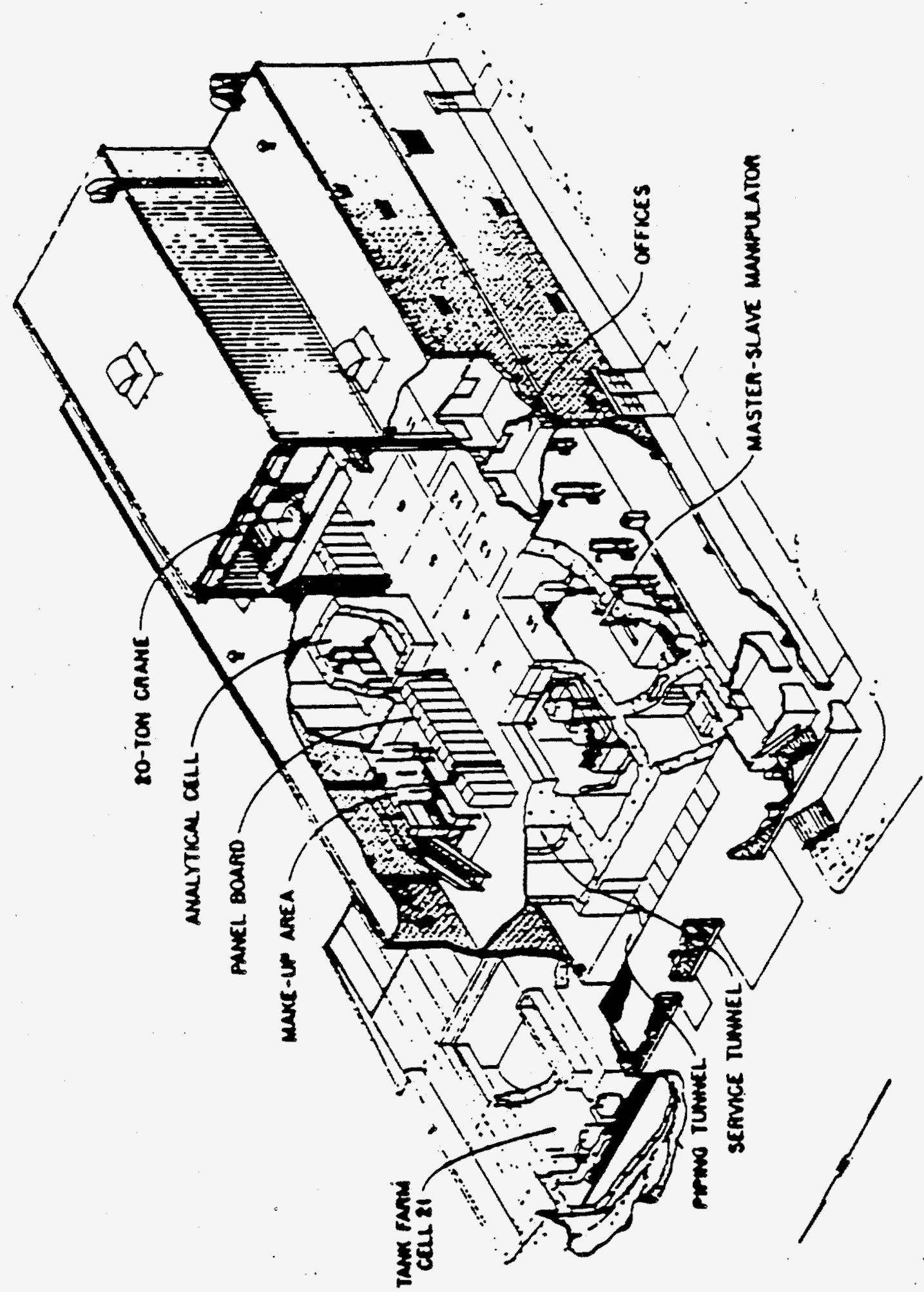


WHC-SD-WM-TA-160

Revision 0

Figure D-29. Building 3517 Floor Plan.

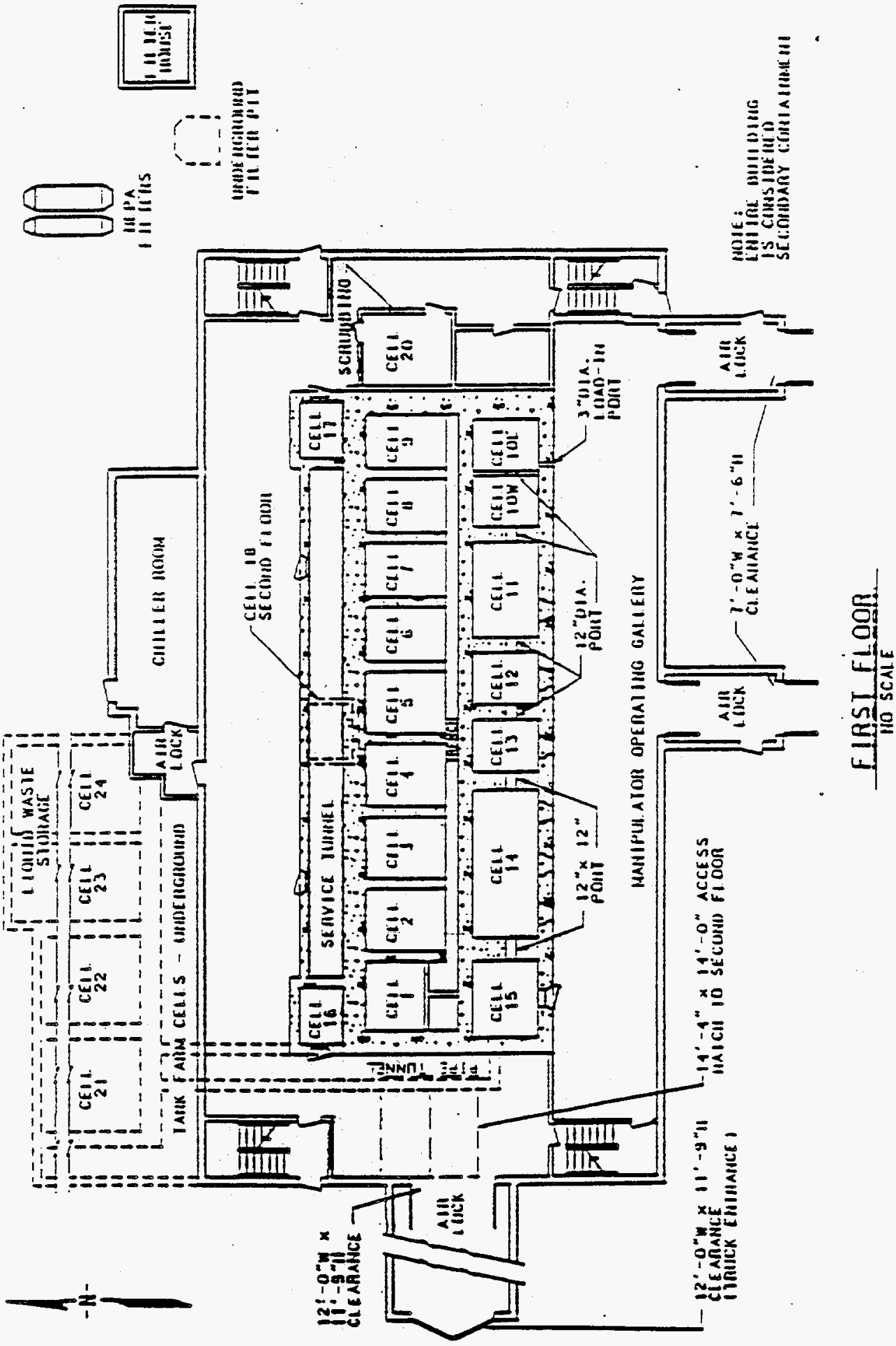


WHC-SD-WM-TA-160

Revision 0

Figure D-30. Building 3047 Arrangement.

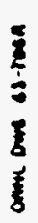

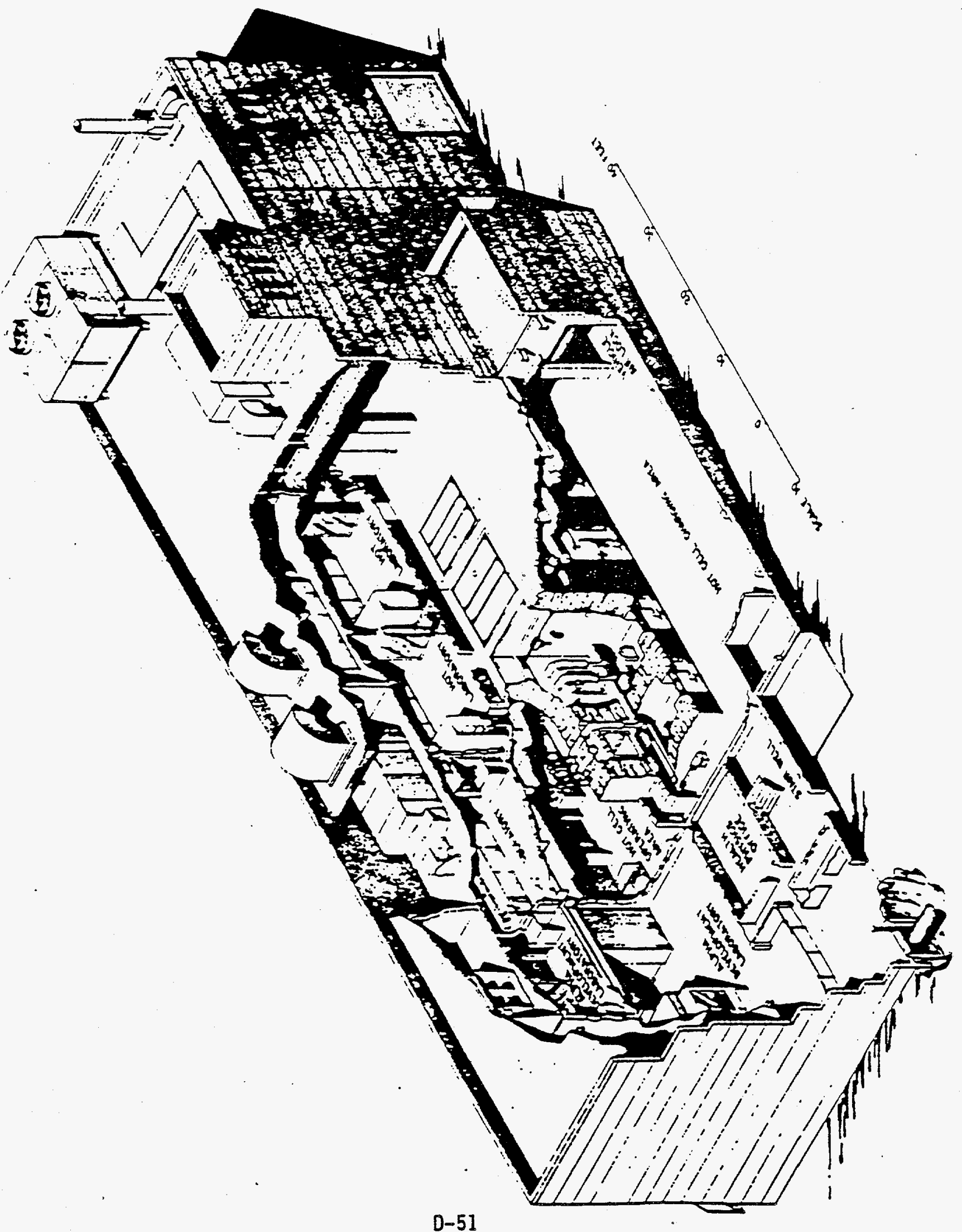


WHC-SD-WM-TA-160

Revision 0

Figure D-31. Building 3047 Floor Plan.
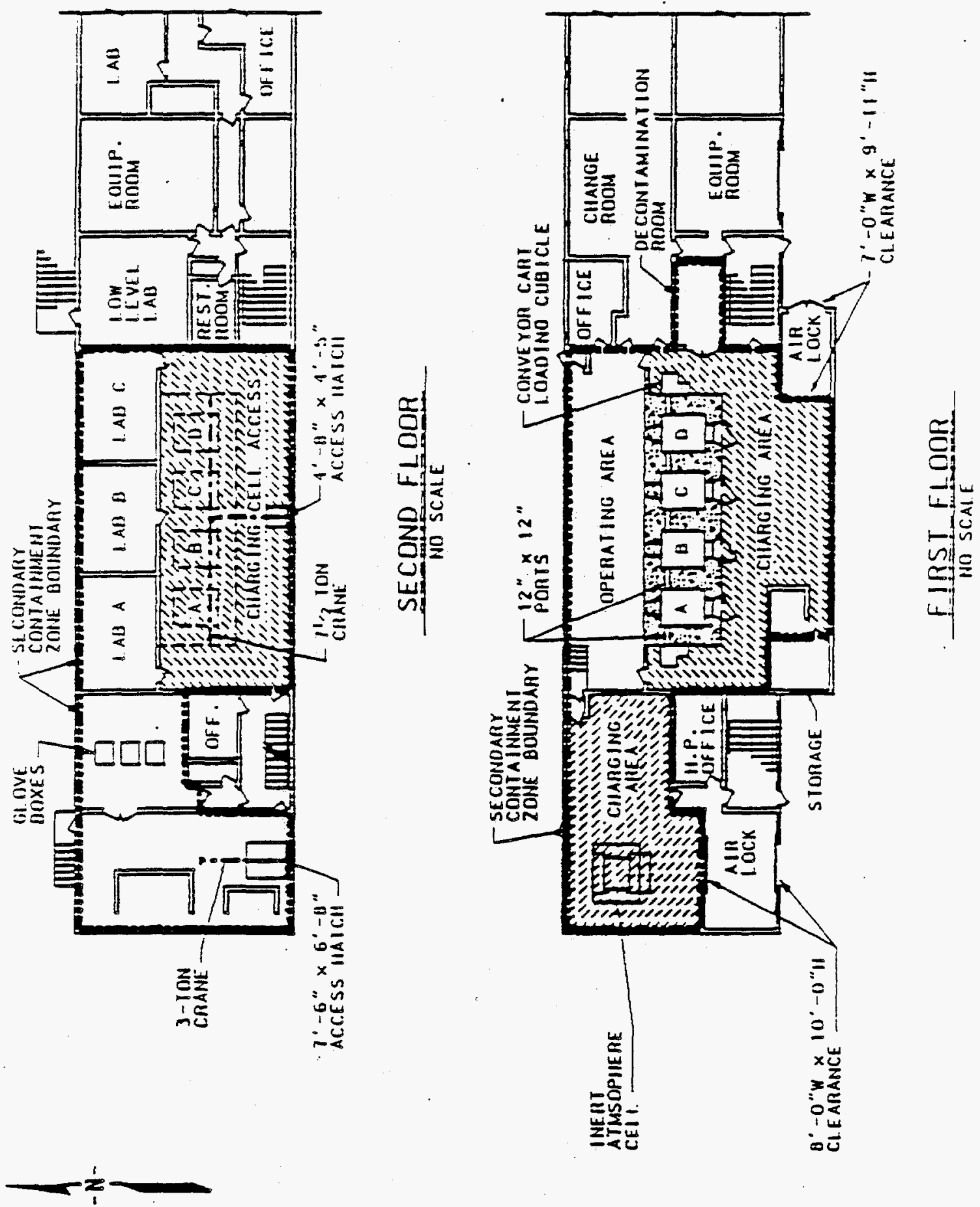
WHC-SD-WM-TA-160

Revision 0

APPENDIX D3

SAMPLE SITE GO-NO-GO ANALYSIS, 222-S LABORATORY 
WHC-SD-WM-TA-160

Revision 0

This page intentionally left blank. 
Table D-3. Preliminary Site Screening Level 2. (3 sheets)

Technology: SettLe DEcant Group Number: $\forall 1$

\begin{tabular}{|c|c|c|c|c|}
\hline & $\begin{array}{l}\text { Waste } \\
\text { Yolume } \\
\text { Constraint }\end{array}$ & $\begin{array}{l}\text { Cell } \\
\text { Size }\end{array}$ & $\begin{array}{c}\text { Hot } \\
\text { Cel1 Equip } \\
\text { Access }\end{array}$ & $\begin{array}{l}\text { Curie } \\
\text { Loading }\end{array}$ \\
\hline 222-5 Building & Y & & & \\
\hline Cell IEI & & $Y$ & $Y$ & $Y$ \\
\hline $\mathrm{Ce} 11$ IE2 & & $Y$ & Y & $Y$ \\
\hline Cell IF & & $Y$ & Y & Y \\
\hline Cell IA & & $N$ & $Y$ & $Y$ \\
\hline Cell IIA (Pods) & & $N$ & $Y$ & $Y$ \\
\hline WESF & $Y$ & & & \\
\hline $\mathrm{Cell} B$ & & $y$ & Y & $Y$ \\
\hline $\mathrm{Cell} \mathrm{C}$ & & y & $y$ & $y$ \\
\hline Cel1 0 & & $y$ & $Y$ & Y \\
\hline Cell E & & $Y$ & $y$ & $Y$ \\
\hline 324 Building & $Y$ & & & \\
\hline $\mathrm{Cell} \mathrm{C}$ & & $Y$ & Y & Y \\
\hline Cell 0 & & $Y$ & $Y$ & $Y$ \\
\hline Cell South & & $Y$ & $Y$ & $Y$ \\
\hline Ceill East & & $Y$ & Y & $Y$ \\
\hline 325 Building & $Y$ & & & \\
\hline Cell A & & $Y$ & $Y$ & $Y$ \\
\hline Cell B & & $Y$ & $Y$ & $Y$ \\
\hline Cell C & & $\bar{Y}$ & $Y$ & $Y$ \\
\hline Cell SAL & & Y & Y & $Y$ \\
\hline
\end{tabular}




$$
\begin{gathered}
\text { WHC-SD-WM-TA-160 } \\
\text { Revision } 0
\end{gathered}
$$

Table D-3. Preliminary Site Screening Level 2. (3 sheets)

\begin{tabular}{|c|c|c|c|c|c|}
\hline & & $\begin{array}{l}\text { Waste } \\
\text { Volume } \\
\text { Constraint }\end{array}$ & $\begin{array}{l}\text { Cell } \\
\text { Size }\end{array}$ & $\begin{array}{c}\text { Hot } \\
\text { Cel1 Equip } \\
\text { Access } \\
\end{array}$ & $\begin{array}{l}\text { Curie } \\
\text { Loading }\end{array}$ \\
\hline 327 Building & & $Y$ & & & \\
\hline \multicolumn{6}{|l|}{$\mathrm{Ce} 11 \mathrm{~B}$} \\
\hline $\mathrm{Cell} \mathrm{C}$ & 7 & & $N$ & $Y$ & $Y$ \\
\hline \multicolumn{6}{|l|}{ Cell $D$} \\
\hline \multicolumn{6}{|l|}{ Ce]1 E } \\
\hline Cell G & \} & & $Y$ & $Y$ & Y \\
\hline \multicolumn{6}{|l|}{ FMEF } \\
\hline \multicolumn{6}{|l|}{ Cel1 132} \\
\hline Cell 133 & $\zeta 5$ & & $Y$ & $Y$ & $Y$ \\
\hline \multicolumn{6}{|l|}{ Cell 134} \\
\hline $\begin{array}{lll}135 \\
136 \\
\end{array}$ & \} 0 & & $Y$ & $y$ & $Y$ \\
\hline Cell 137 & 5 & & $Y$ & $Y$ & $Y$ \\
\hline \multicolumn{6}{|c|}{ Cell $138>0$} \\
\hline Cel1 139 & 5 & & $Y$ & $Y$ & $Y$ \\
\hline \multicolumn{6}{|l|}{$\mathrm{Ce} 11 \quad 142$} \\
\hline Ceil 143 & 35 & & $Y$ & $Y$ & $Y$ \\
\hline Cell 144 & $J$ & & & & \\
\hline Cel1 145 & & & $Y$ & $Y$ & $Y$ \\
\hline Cel1 146 & & & $Y$ & $Y$ & $Y$ \\
\hline Cell 147 & & & $Y$ & $Y$ & $Y$ \\
\hline Cel1 325 & & & $Y$ & $Y$ & $Y$ \\
\hline Cell 507 & & & $Y$ & $Y$ & $Y$ \\
\hline
\end{tabular}
Technology: SeTtLE/DECANT Group Number: 1 
WHC-SD-WM-TA-160

Revision 0

Table D-3. Preliminary Site Screening Level 2. (3 sheets)

Technology: Setre/Decant Group Number: 1

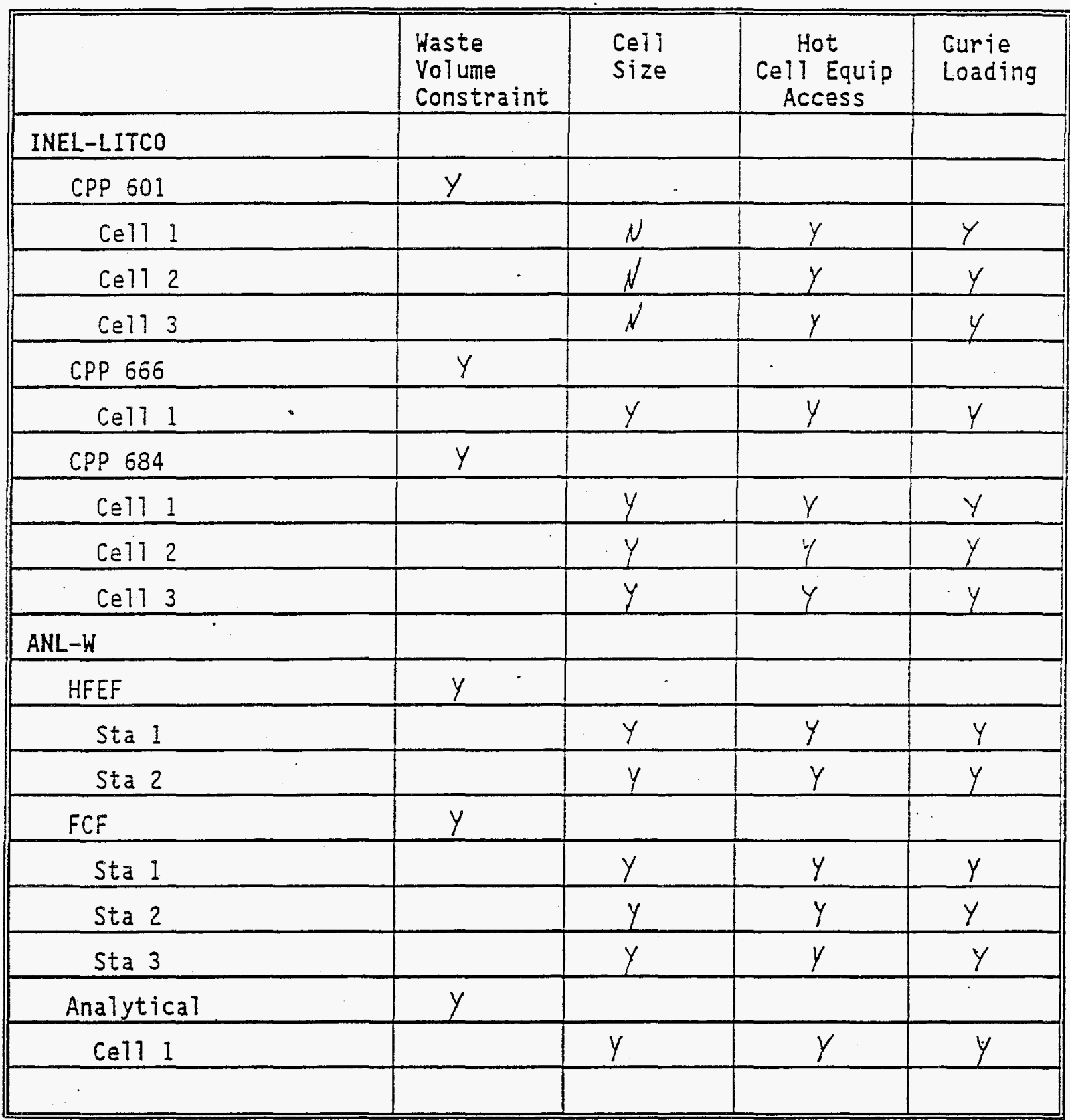


WHC-SO-WM-TA-160

Revision 0

This page intentionally left blank. 
WHC-SD-WM-TA-160

Revision 0

APPENDIX E

SITE SURVEY ANALYSIS DATA

E-1 
WHC-SD-WM-TA-160

Revision 0

\section{LIST OF FIGURES}

E-1 Site Evaluation Worksheet ............... E-3

\section{LIST OF TABLES}

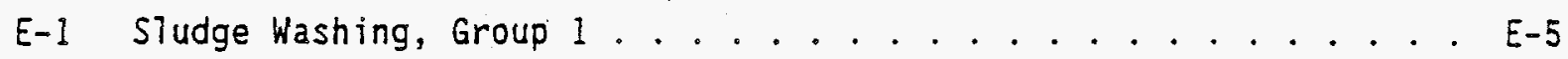

E-2 Sludge Washing, Group $3 \ldots \ldots \ldots$ E-6

E-3 Sludge Washing, Group $4 \ldots \ldots \ldots$ E-7

E-4 Settie/Decant, Group 1 ................. . E-8

E-5 Filtration, Group 1.................... E-g

E-6 Filtration, Group 2 ................ . . . . . . . . . .

E-7 Filtration, Group $3 \ldots \ldots \ldots$. . . . . . . . . . . . .

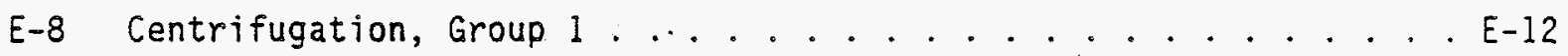

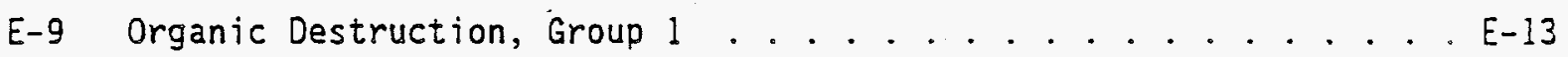

E-10 Ion Exchange, Case 1, Group 1................. E-14

E-11 Ion Exchange, Case 1, Group 2............... E-15

E-12 Ion Exchange, Case 2, Group 1.............. E-16 


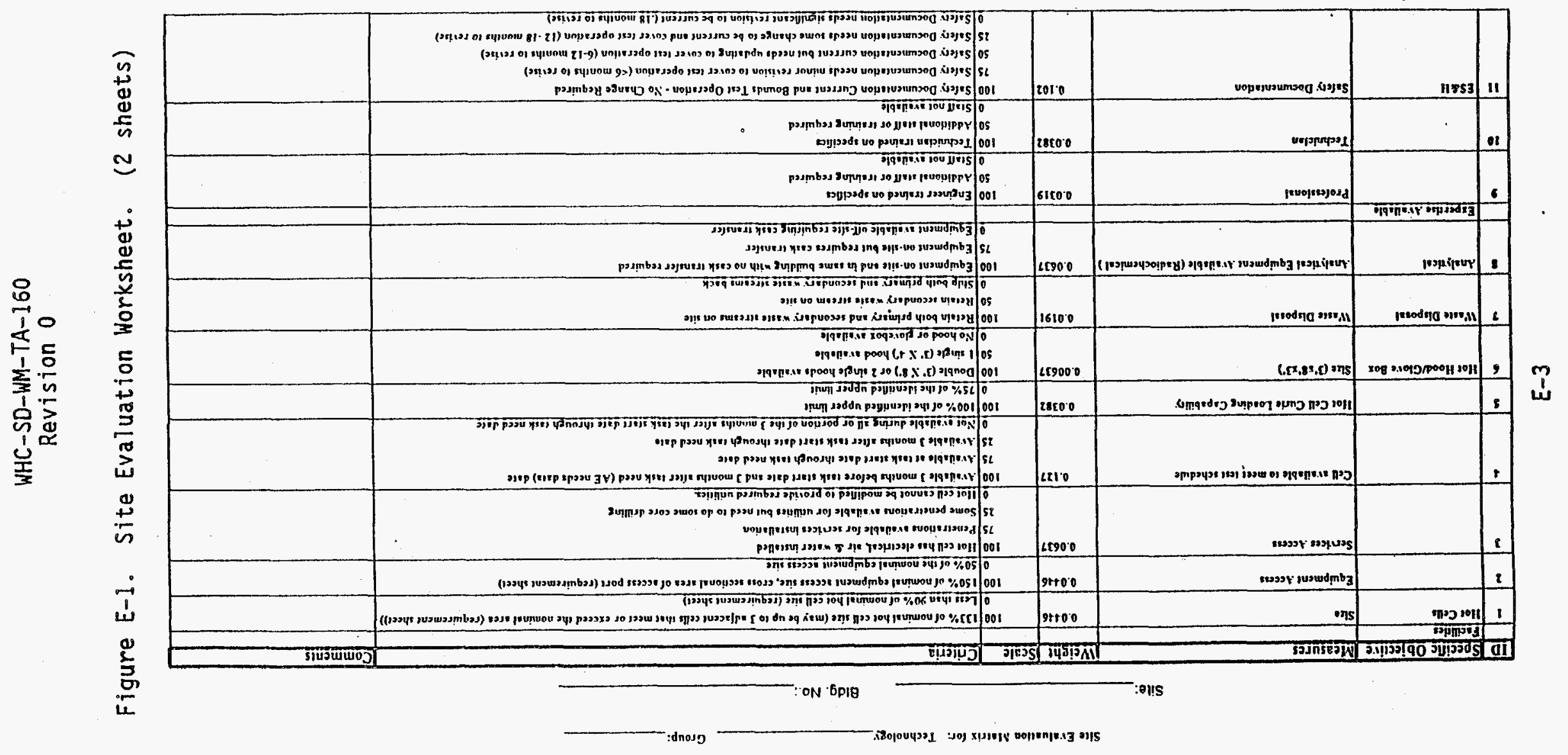




\section{WHC-SD-WM-TA-160 \\ Revision 0}

Figure E-1. Site Evaluation Worksheet. (2 sheets)

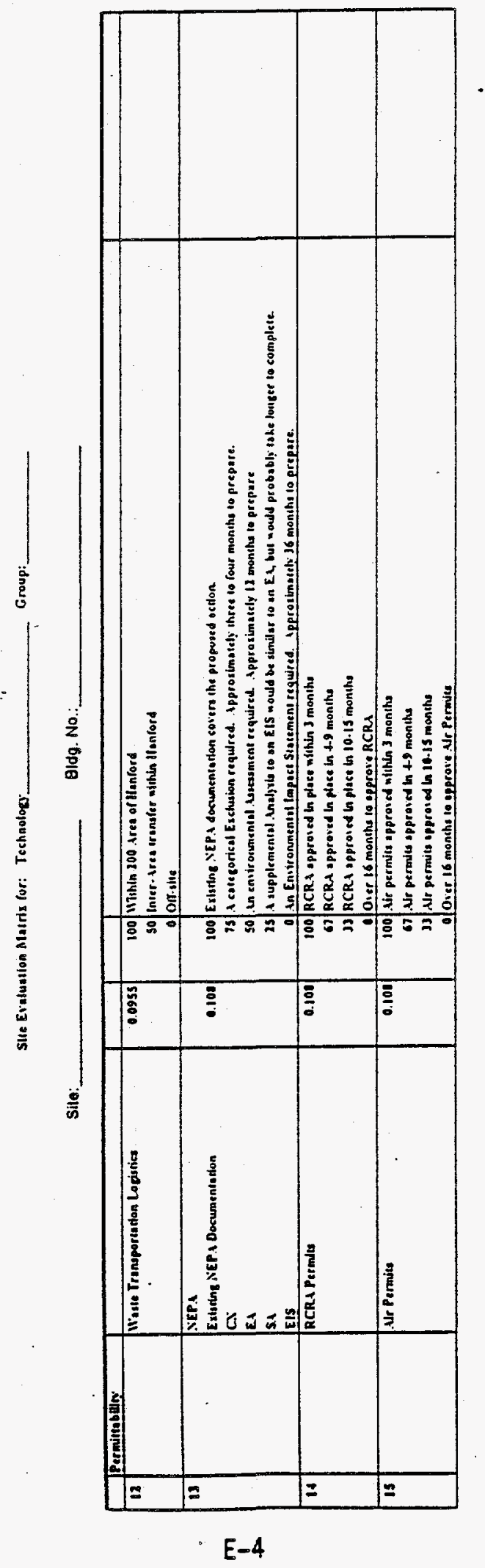




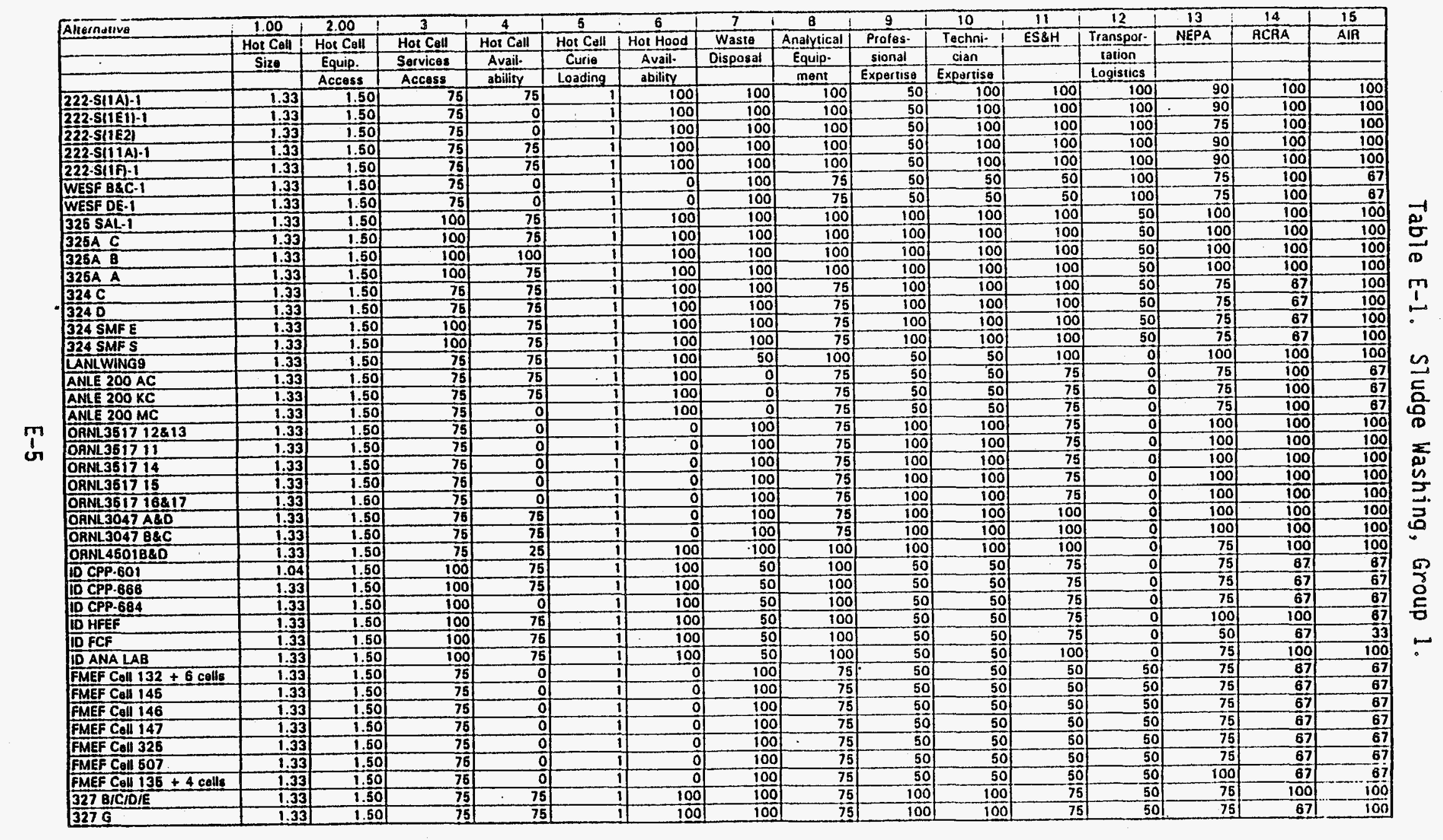




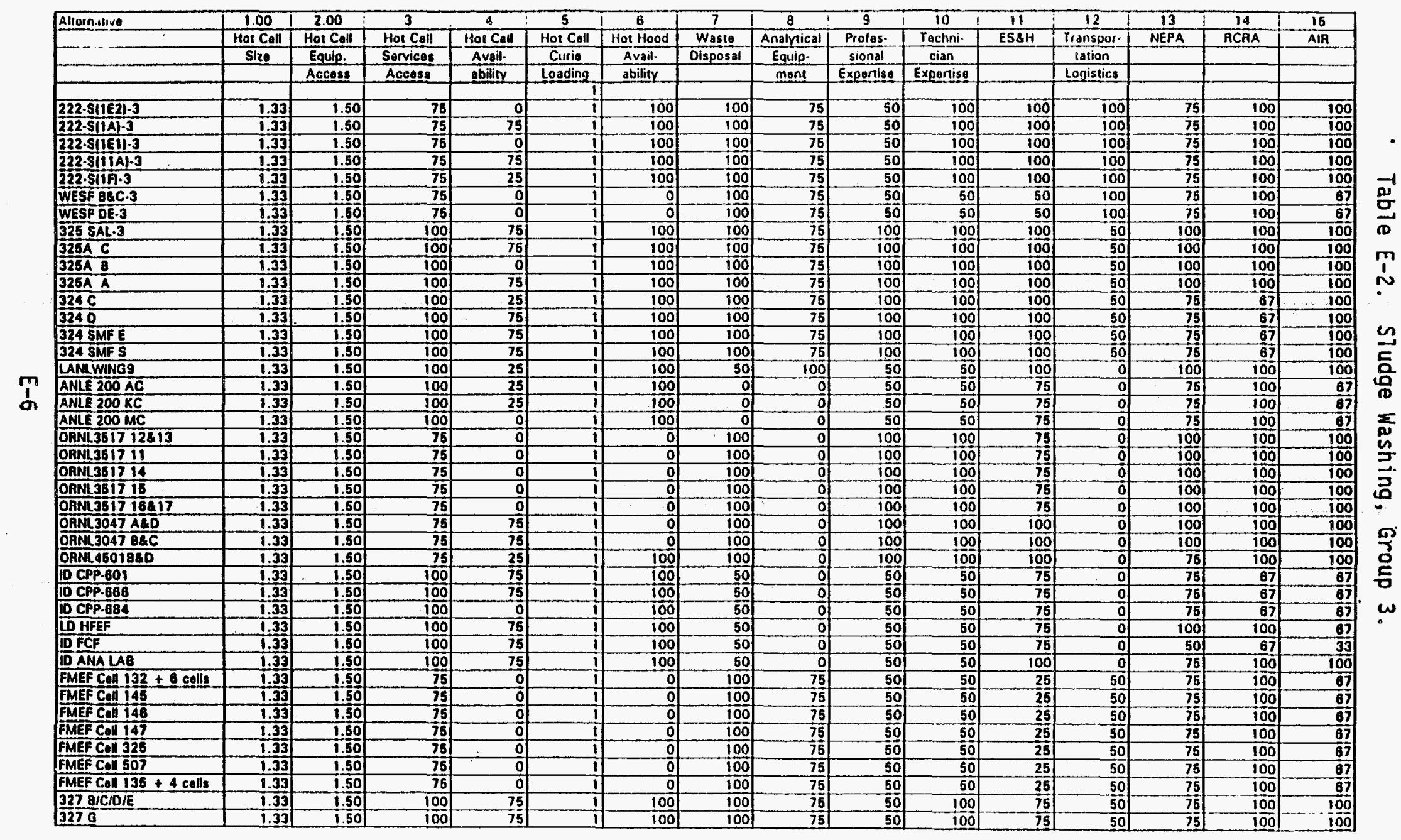

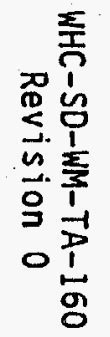




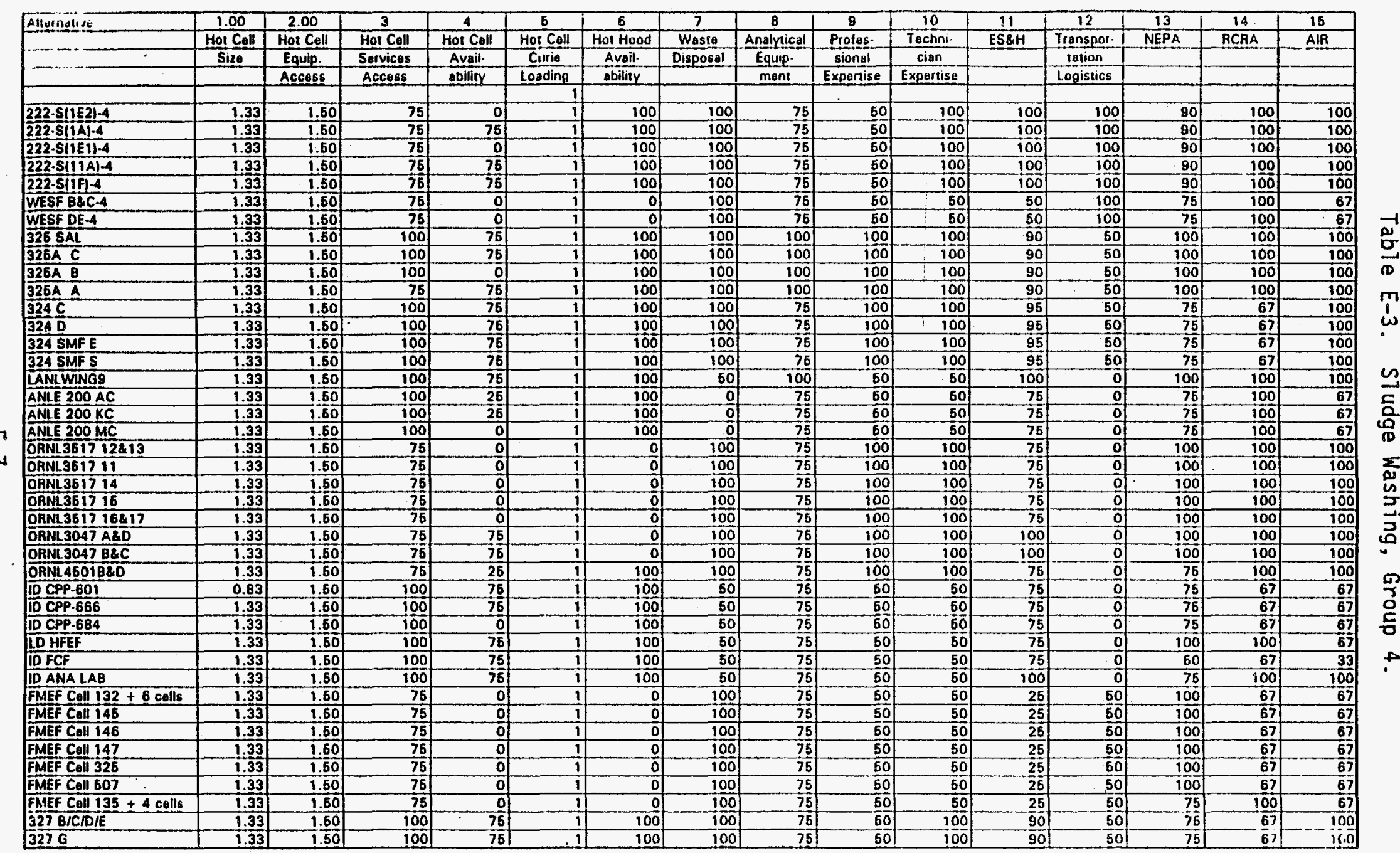




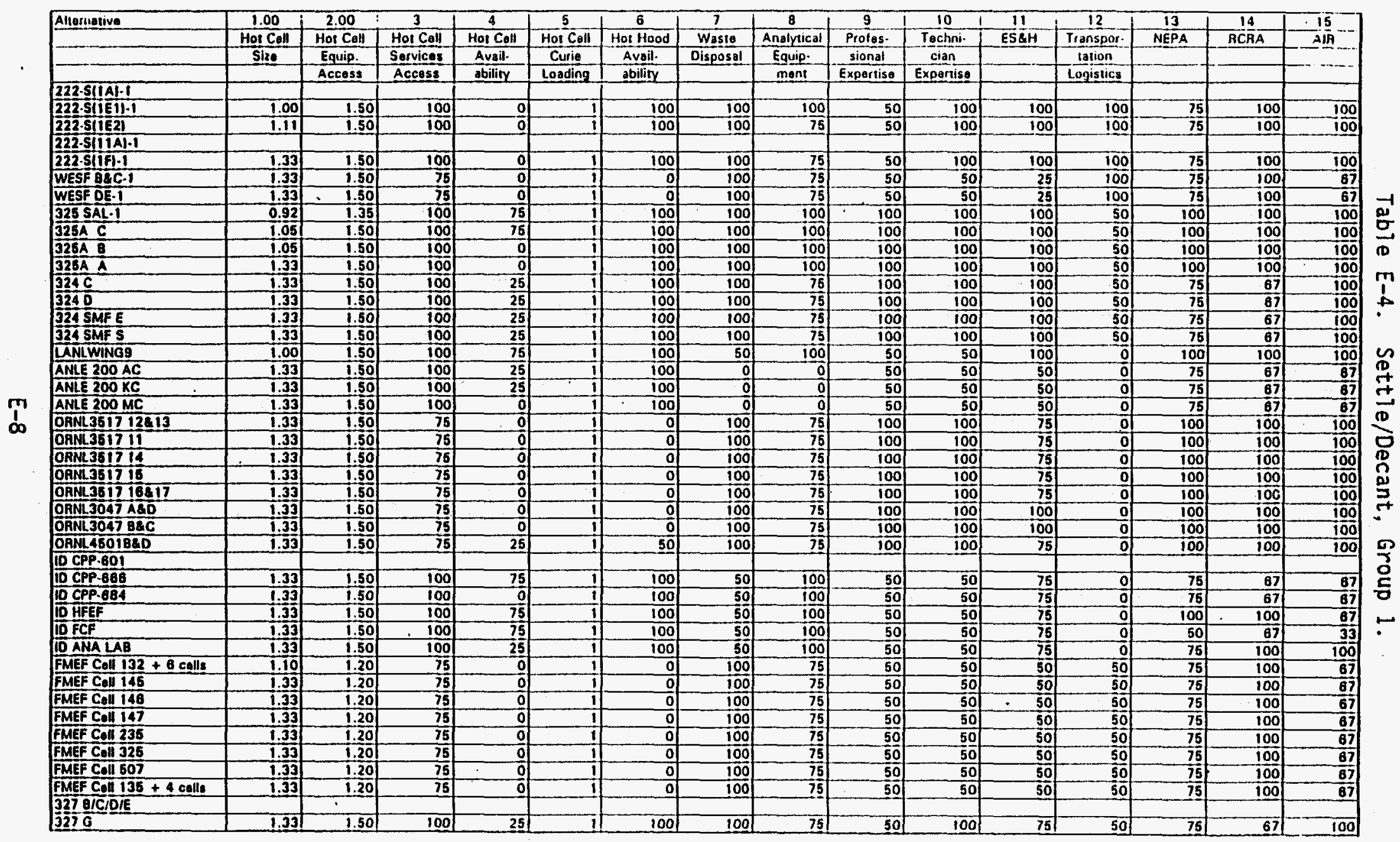

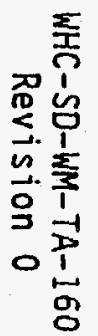




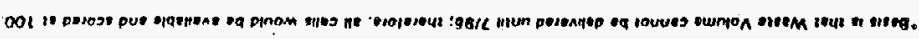

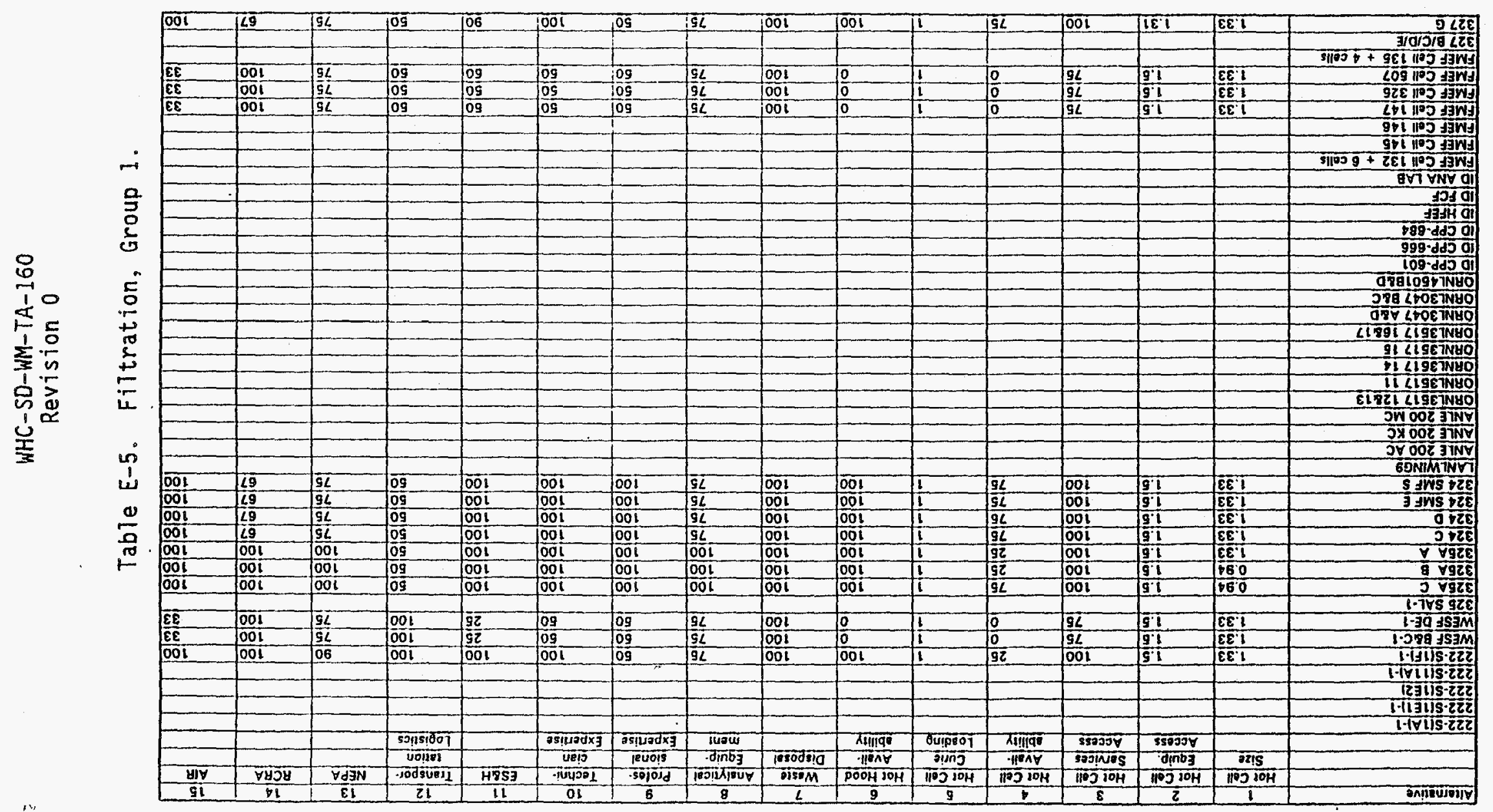




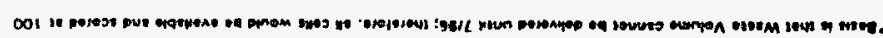

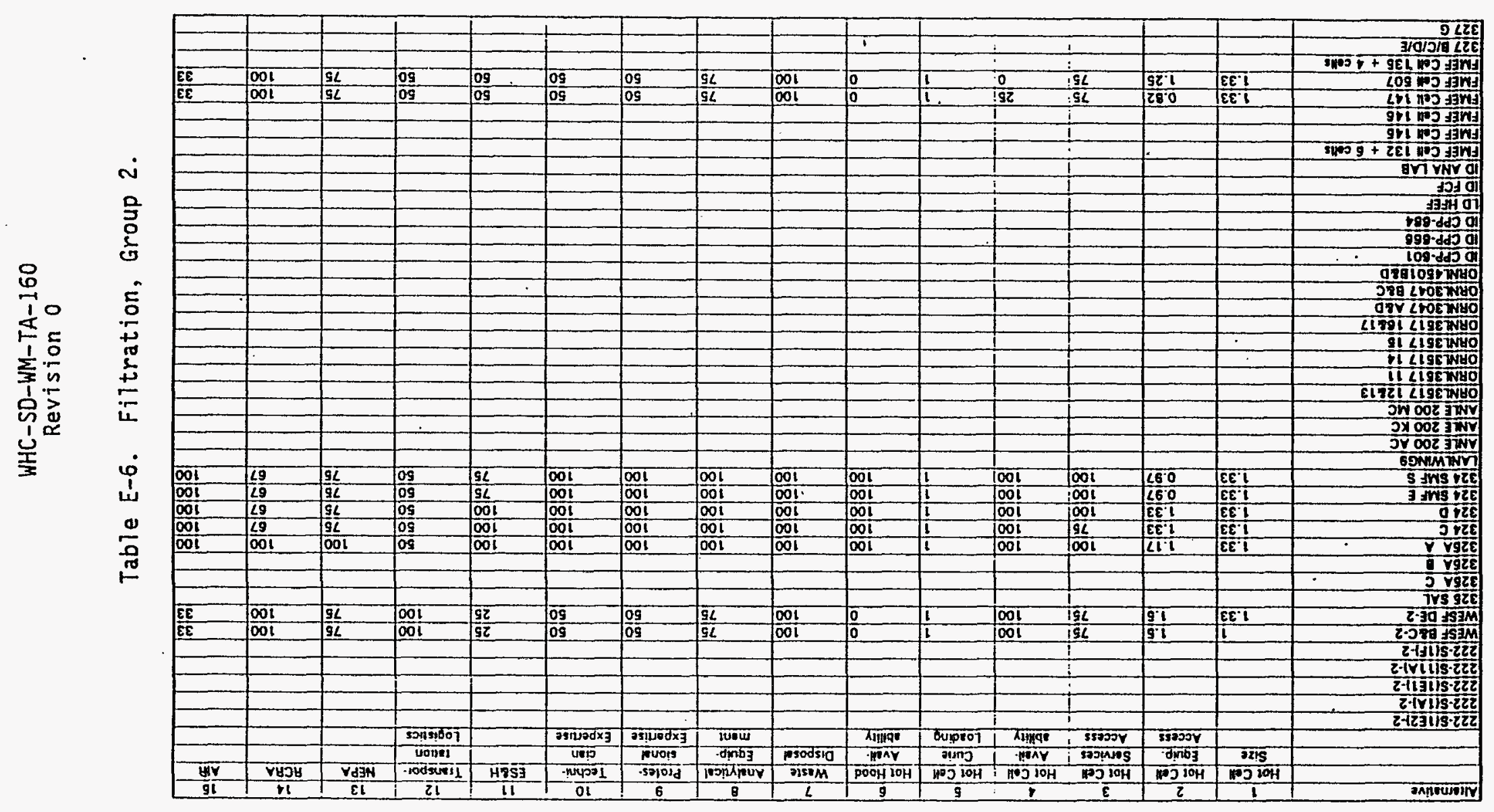

운 


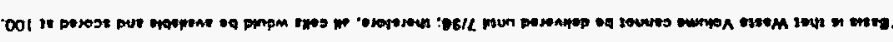

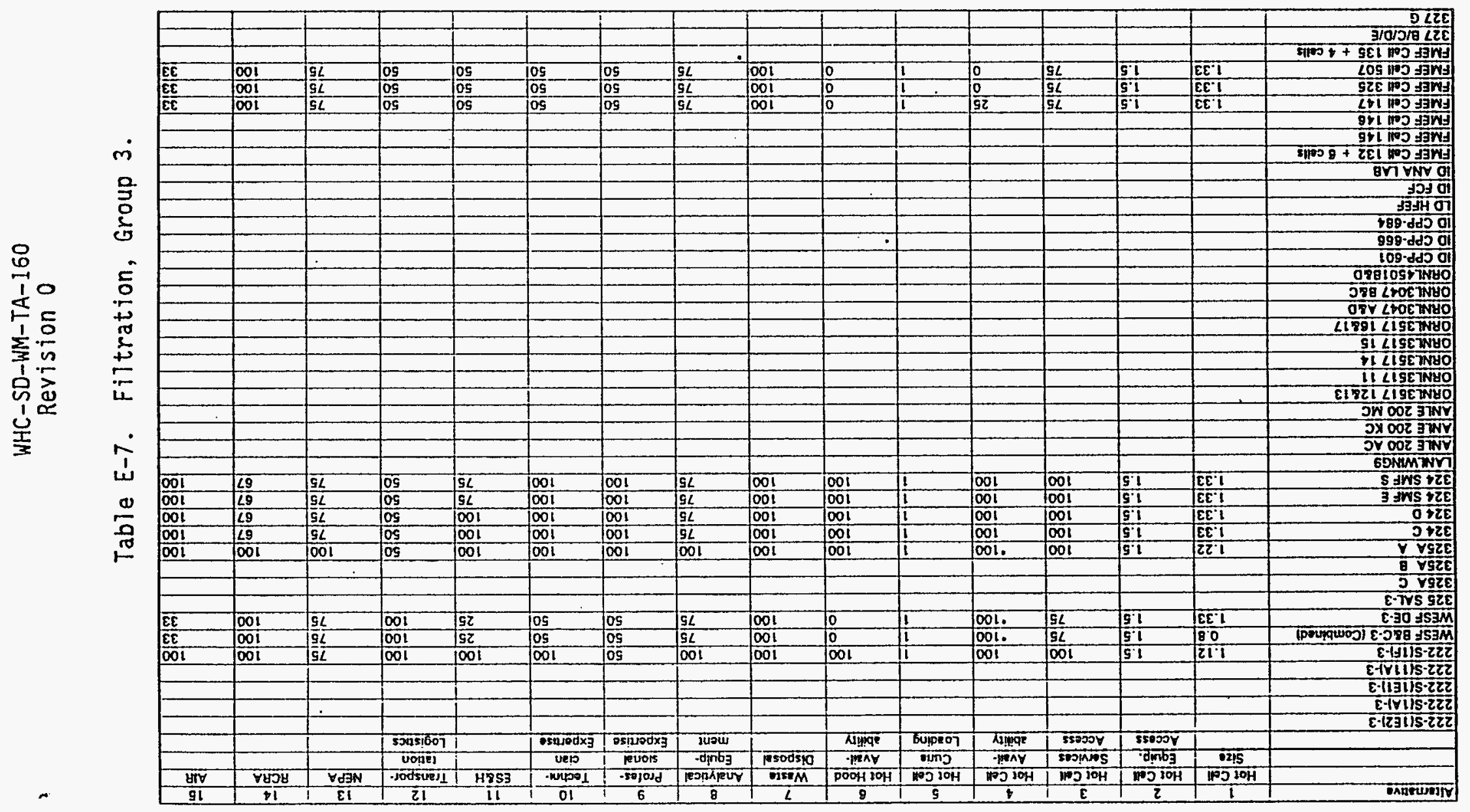




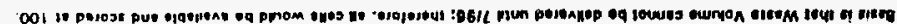

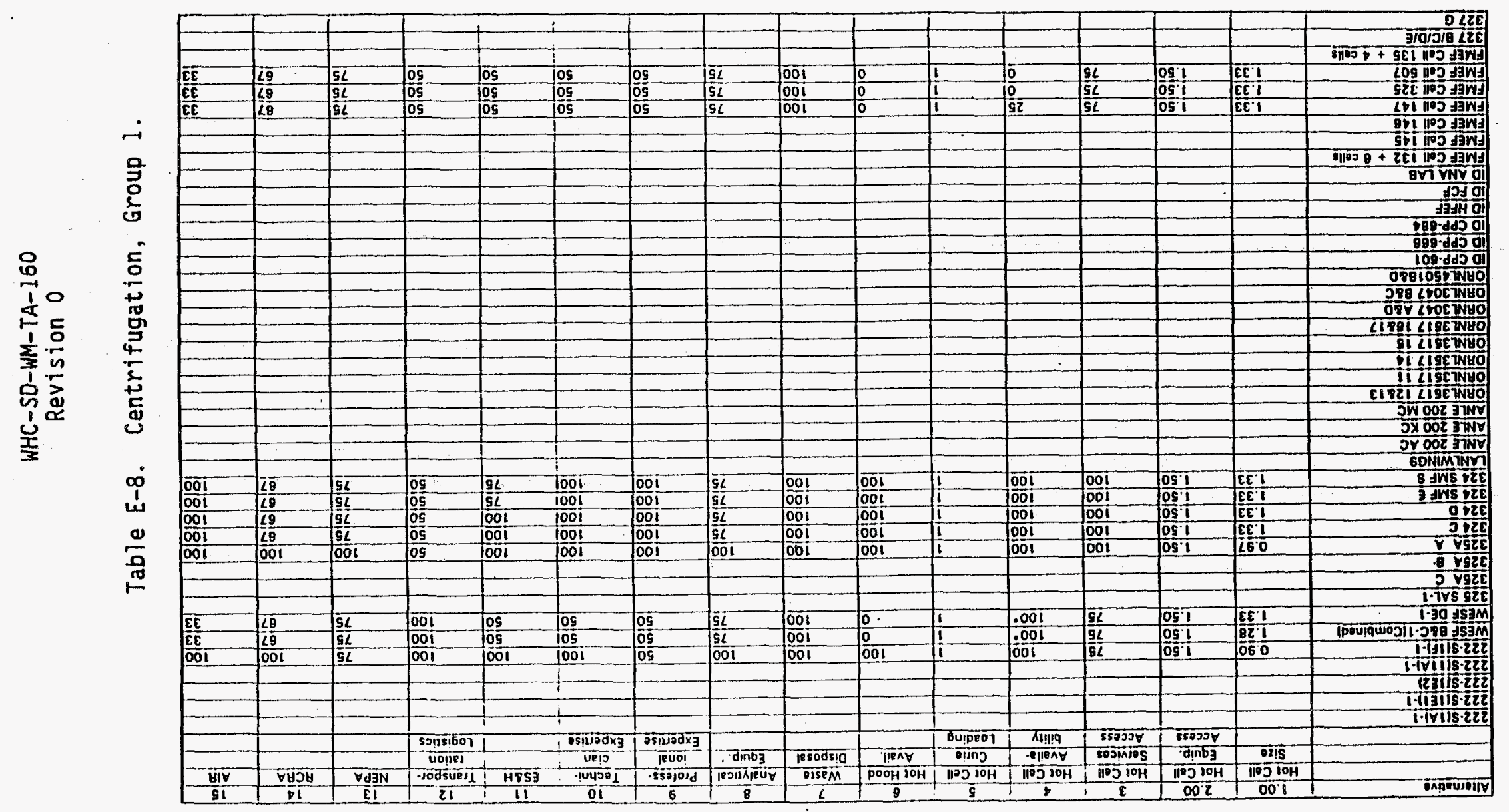




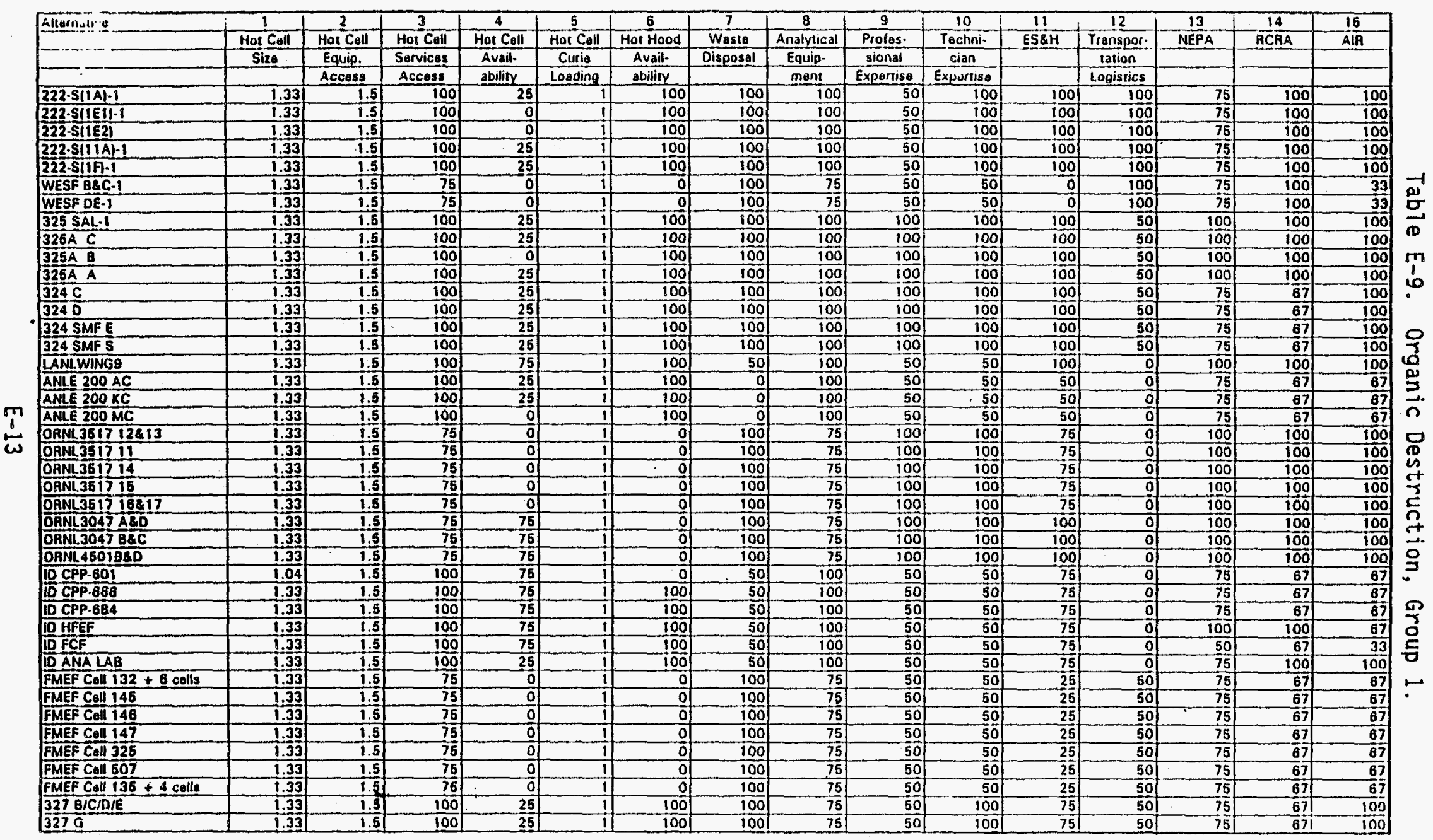

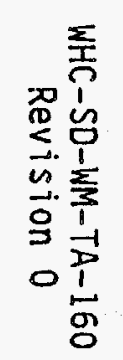




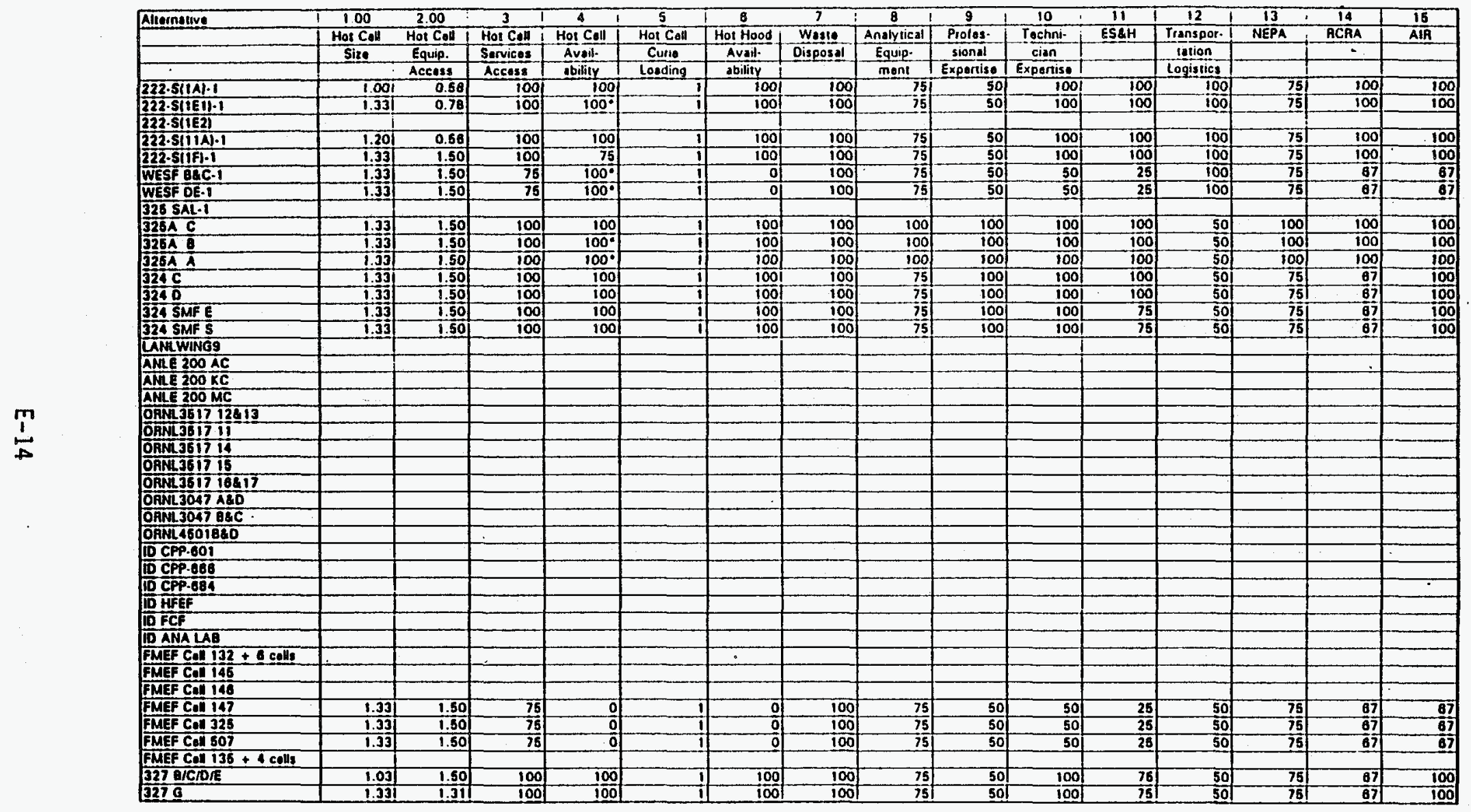

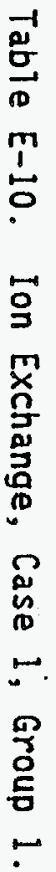




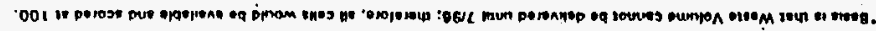

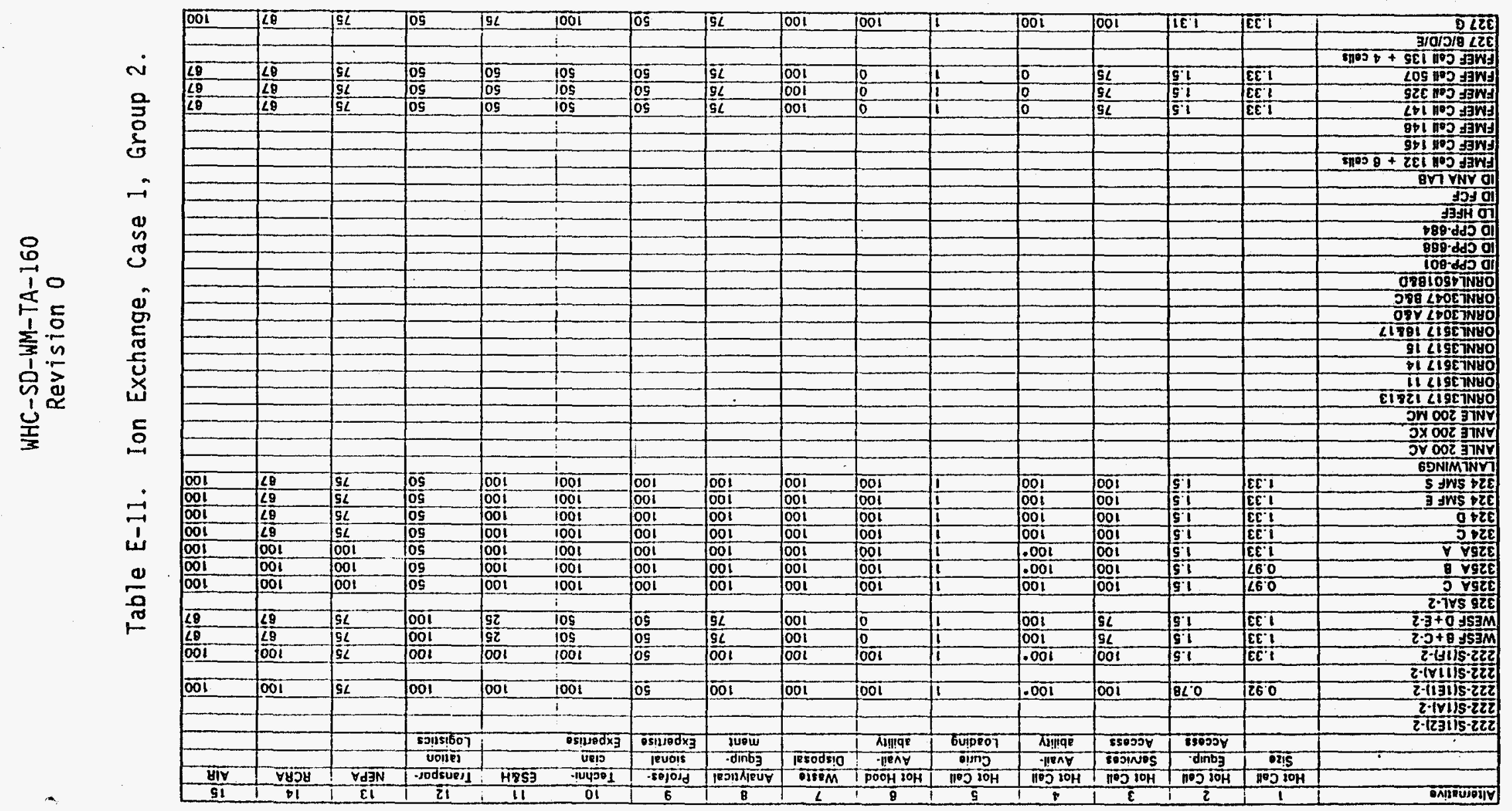




\section{WHC-SD-WM-TA-160 \\ Revision 0}

Table E-12. Ion Exchange, Case 2, Group 1.

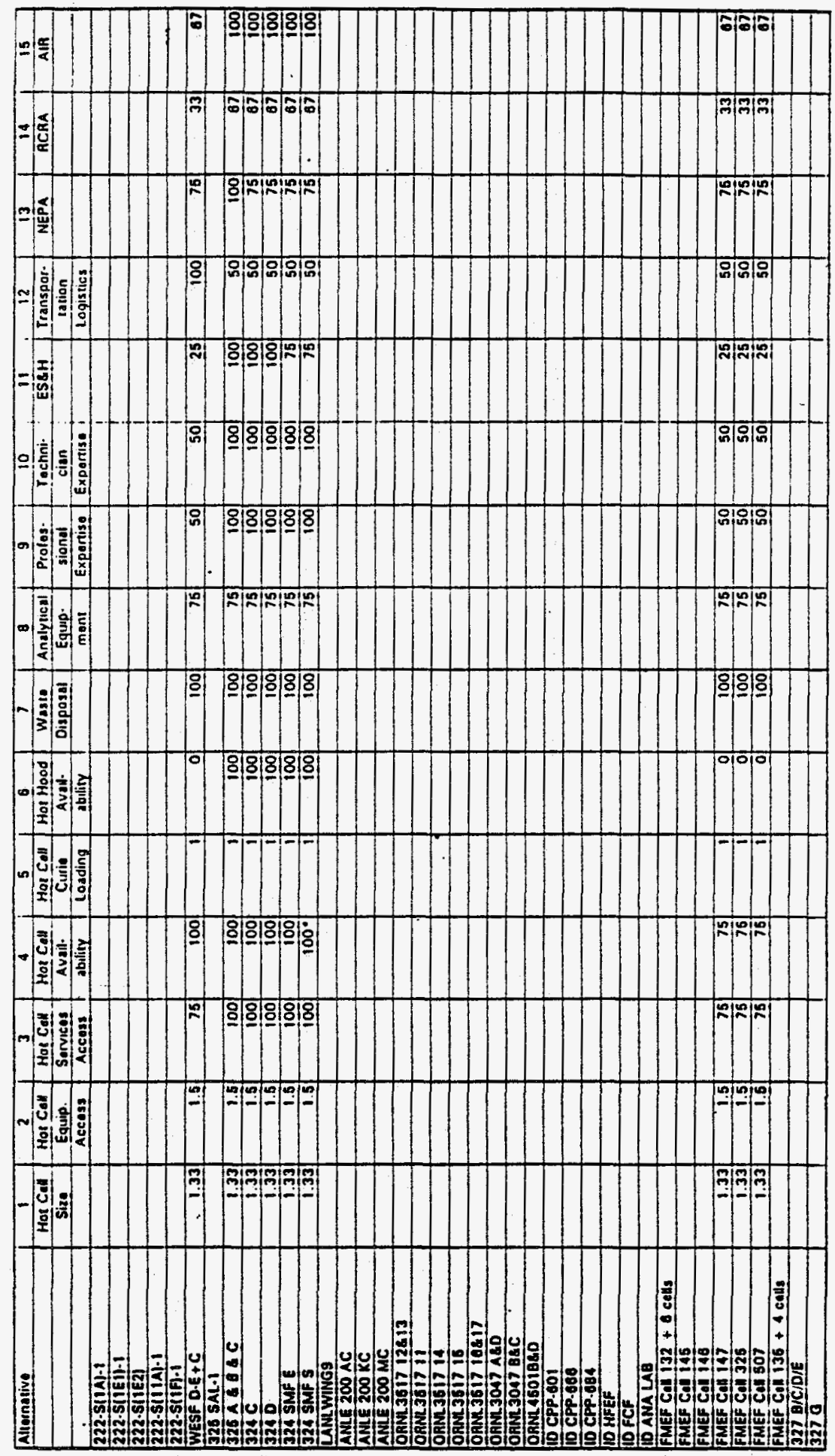


WHC-SD-WM-TA- 160

Revision 0

\section{APPENDIX F}

DECISION ANALYSIS METHODOLOGY AND SAMPLES 
WHC-SD-WM-TA-160

Revision 0

\section{CONTENTS}

FI. SITING EVALUATION AND RATING PROCESS ................. . . . . .

FI.1 OVERVIEW OF THE DECISION PROCESS . . . . . . . . . . . . . . F-3

F1.1.1 Alternatives ................ F-4

Fl.1.2 Objectives ............... . . F-4

F1.1.3 Criteria Scales................ F-5

F1.1.4 Weights............... . . F-5

FI.1.5 Overall Rating .............. F-g

F2.0 SITE EVALUATION . . . . . . . . . F-g

F2.I ALTERNATIVE EVALUATION FOR ION-EXCHANGE ISSUE CASE I

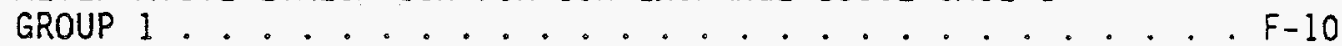

F2.1.1 Overall Ranking ................ . . . . . . . .

F2.1.2 Performance Profiles . . . . . . . . . . . . F-10

F2.1.3 Sensitivity Analysis ............ . F-10

F2.2 TEST GROUP SITING RECOMMENDATION ........... . F-10

F3.0 REFERENCES ............................... . . . . . . . .

\section{LIST OF FIGURES}

F-1 Performance Profile for 325A A . . . . . . . . . . . . . . F-11

F-2 Performance Profile for $325 \mathrm{~A}$ B . . . . . . . . . . . . . . . F-12

F-3 Performance Profile for $325 \mathrm{~A} \mathrm{C} \mathrm{.} \mathrm{.} \mathrm{.} \mathrm{.} \mathrm{.} \mathrm{.} \mathrm{.} \mathrm{.} \mathrm{.} \mathrm{.} \mathrm{.} \mathrm{.} \mathrm{.} \mathrm{.} \mathrm{.} \mathrm{F-13}$

F-4 Performance Profile for 222-S(IF) . . . . . . . . . . . . . F-14

F-5 Performance Profile for 222-S(IEI) . . . . . . . . . . . F-15

\section{LIST OF TABLES}

F-1 Decision Analysis Objectives and Scales . . . . . . . . . . F-6 


\section{APPENDIX F}

\section{DECISION ANALYSIS METHODOLOGY AND SAMPLES}

\section{F1.0 SITING EVALUATION AND RATING PROCESS}

This section describes the methodology for rating the alternative facilities based on "hot test" requirements. Facility rankings were developed for each testing issue group. The following discusses the methodology and provides an example of its application.

The testing issue groups analyzed were as follows:

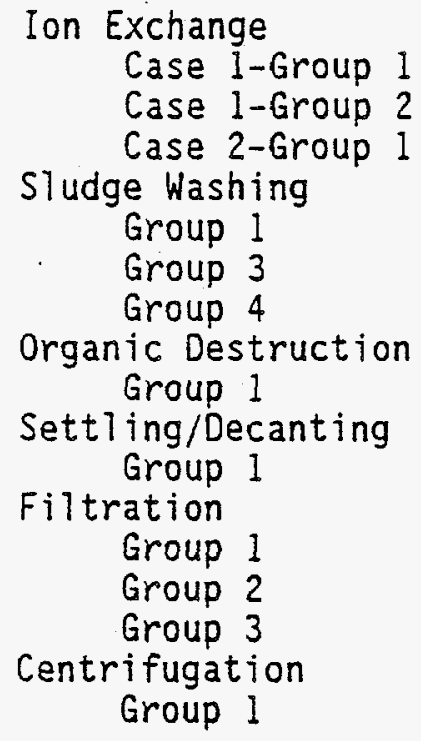

The Multiattribute Utility (MAU) theory was used as the decision analysis methodology to score the "hot testing" facilities and determine the rankings for each testing issue group. For this, several meetings were held with specialists on the various testing procedures and technologies. During these meetings the objectives, criteria (measures), and the weights (the importance) for criteria were established. Each criteria for the "hot testing" facilities were then scored for every testing issue group. The weights were applied to the criteria in the MAU process to produce an overall score for each alternative ("hot test" facility).

\section{FI.1 OVERVIEN OF THE DECISION PROCESS}

The steps in the decision process were as follows.

- Develop the overall objective of the project. 
WHC-SD-WM-TA- 160

Revision 0

- Develop fundamental objectives or goals that will allow achievement of the overall objective.

Fundamental objectives are broken down into separate components or sub-objectives by a process of further specification. This continues until a level is arrived at for which measures can be defined.

- Develop criteria (measures) for the objectives.

Measures are natural scales (e.g., hot cell size) or constructed scales (clear definitions of levels of performance with an assigned score).

- Develop weights for each of the objectives and criteria using the swing weighting method.

- Convert to a common measure by developing value functions for the criteria.

- Aggregate the alternative's scores on individual measures into an overall rating for each alternative.

\section{F1.1.1 Alternatives}

Alternatives were reviewed based on the set of objectives and measures developed. Some alternatives were screened out before the decision analysis process because they lacked the necessary features (e.g., inability to ship waste to the facility or some physical aspect of the facility was not adequate).

\section{FI.1.2 objectives}

Objectives are statements on what we want to achieve (Keeney 1992). Objectives with criteria and natural or constructed scales are listed for each of the technology subgroups (Table 4-1).

The overall objective was identified as: Comparatively rank the overall capability of the available hot test facilities and infrastructure to support the "hot testing" requirements of a technology issue group.

Fifteen fundamental objectives were identified as important to this overall goal:

Hot cell size

Hot cell equipment access

Hot cell services access

Hot cell availability to meet test schedule

Hot cell curie loading capability

Hot hood/gloveboxes

Waste disposal (tank sample residue and test by-products)

Analytical equipment available (radiochemical)

$$
F-4
$$


WHC-SD-WM-TA-160

Revision 0

Professional expertise

Technical expertise

Environmental, Safety, \& Health (ES\&H)

Sample transport

National Environmental Policy Act of 1969 (NEPA) Permits

Resource Conservation and Recovery Act of 1976 (RCRA) Permits

Air Permits.

Cost was. not considered in this decision process because the goal was to establish alternatives based solely on technical capability and availability at this stage. Objectives that clearly showed no significant variation from site to site and those objectives (requirements) that could be easily remedied were dropped from consideration (e.g., the common availability of master/slave manipulators in hot cells or a minor piece of equipment that could easily be purchased).

\section{FI.1.3 Criteria Scales}

Criteria are also called performance measures or attributes. They measure the degree to which the objectives are achieved. Normally fundamental objectives are further broken down into more specific sub-objectives untiT a criterion or performance measure was identified. In this case, only one level of objectives was needed.

Most of the measures were constructed scales that were established by a team composed of analytical chemists, technology development engineers, and project engineers. In this case, most of the measures were constructed scales and had a common scale of 0 to 100 (see Table F-1). The scales were constructed to minimize ambiguity, so a given level of performance could be clearly scored. The constructed scale's value functions consisted of numerical values assigned to levels of performance with a common scale from 0 to 100 .

Natural scales were developed for hot cell size, hot cell equipment access and hot cell curie loading capability. The hot cell size measure was a ratio of the cell floor area to the nominal floor area requirement. The hot cell equipment access measure was a ratio of the cell's equipment access size to the nominal hot cell equipment access requirement. The hot cell curie loading capability measure was a ratio of the cell's curie loading capability to the upper limit curie loading needed. The value functions were linear and were provided a scale between 0 and 100 .

For the natural scales such as hot cell size, if the value for the cell was above the needed range of the scale, it was given a maximum score of 100 because excess size was not considered a benefit.

\section{F1.1.4 Weights}

Weights for the objectives capture the tradeoff at each level between the objectives at that level; the highest weights are matched with the most important objectives or criteria. The importance of the objectives are compared at each level with each other. 
WHC-SD-WM-TA-160

Revision 0

Table F-1. Decision Analysis Objectives and Scales. (sheet 1 of 3 )

\begin{tabular}{|c|c|c|}
\hline Objective & Weight & Scale construction \\
\hline Hot cell size & 0.0447 & $\begin{array}{l}\text { Ratio of cell size to the nominal hot } \\
\text { cell size, floor area }(0.9 \text { to } 1.33) \text {. }\end{array}$ \\
\hline $\begin{array}{l}\text { Hot cell equipment } \\
\text { access }\end{array}$ & 0.0447 & $\begin{array}{l}\text { Ratio of equipment access of cell to } \\
\text { nominal equipment access size, cross } \\
\text { sectional area }(0.5 \text { to } 1.5) \text {. }\end{array}$ \\
\hline $\begin{array}{l}\text { Hot cell services } \\
\text { access }\end{array}$ & 0.0638 & $\begin{array}{l}100 \text { Hot cell has electrical, air, and } \\
\text { water installed. } \\
75 \text { Penetrations are available for } \\
\text { services installation. } \\
25 \text { Some penetrations are available } \\
\text { for utilities but some core } \\
\text { drilling is needed. } \\
0 \text { Hot cell cannot be modified to } \\
\text { provide the required utilities. }\end{array}$ \\
\hline $\begin{array}{l}\text { Hot cell availability } \\
\text { to meet test schedule }\end{array}$ & 0.127 & $\begin{array}{l}100 \text { Available } 3 \text { months before task } \\
\text { start date and } 3 \text { months after } \\
\text { task need date. } \\
75 \text { Available at task start date } \\
\text { through task need date. } \\
25 \text { Available } 3 \text { months after task } \\
\text { start date through task need } \\
\text { date. } \\
0 \text { Not available during all or } \\
\text { portion of the } 3 \text { months after } \\
\text { the task start date through the } \\
\text { task need date. }\end{array}$ \\
\hline $\begin{array}{l}\text { Hot celi curie loading } \\
\text { capability }\end{array}$ & 0.0382 & $\begin{array}{l}\text { Ratio of hot cell curie loading } \\
\text { capability to the desired curie } \\
\text { loading limit, area }(0.75 \text { to } 1.00) \text {. }\end{array}$ \\
\hline Hot hood/gloveboxes & 0.00637 & $\begin{array}{l}100 \text { One double ( } 3 \text { by } 8 \mathrm{ft} \text { ) or two } \\
\text { single hoods available. } \\
50 \text { One single ( } 3 \text { by } 4 \mathrm{ft} \text { ) hood } \\
\text { available. } \\
0 \text { No hood or glovebox available. }\end{array}$ \\
\hline $\begin{array}{l}\text { Waste disposal } \\
\text { (tank sample residue } \\
\text { and test by-products) }\end{array}$ & 0.0191 & $\begin{array}{l}100 \text { Retain both primary and secondary } \\
\text { waste streams onsite. } \\
50 \text { Retain secondary waste stream on } \\
\text { the site onsite. } \\
0 \text { Ship both primary and secondary } \\
\text { waste streams back. }\end{array}$ \\
\hline
\end{tabular}


Tabie F-1. Decision Analysis Objectives and Scales. (sheet 2 of 3)

\begin{tabular}{|c|c|c|}
\hline Objective & Weight & Scale construction \\
\hline $\begin{array}{l}\text { Analytical equipment } \\
\text { available } \\
\text { (radiochemical) }\end{array}$ & 0.0638 & $\begin{array}{l}100 \text { Equipment onsite and in the same } \\
\text { building with no cask transfer } \\
\text { required. } \\
75 \text { Equipment onsite but requires } \\
\text { cask transfer. } \\
0 \text { Equipment is offsite requiring } \\
\text { cask transfer. }\end{array}$ \\
\hline Professional expertise & 0.0319 & $\begin{array}{l}100 \text { Engineer trained on the } \\
\text { specifics. } \\
50 \text { Additional staff or training } \\
\text { required. } \\
0 \text { Staff unavailable. }\end{array}$ \\
\hline Technical expertise & 0.0382 & $\begin{array}{l}100 \text { Technician trained on specifics. } \\
50 \text { Additional staff. or training } \\
\text { required. } \\
0 \text { Staff unavailable. }\end{array}$ \\
\hline $\begin{array}{l}\text { Environmental, Safety, } \\
\text { \& Health }\end{array}$ & 0.102 & 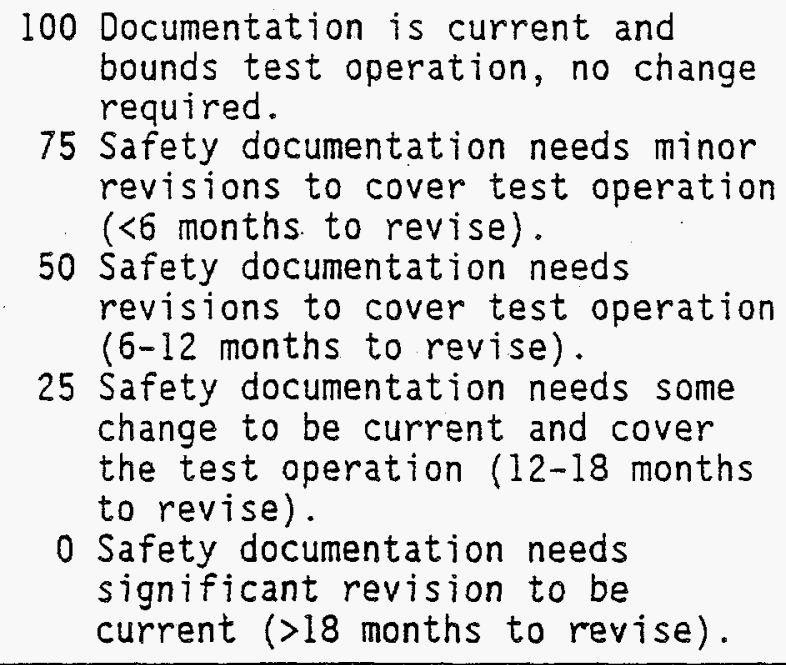 \\
\hline Sample transport & 0.0956 & $\begin{array}{l}100 \text { Within } 200 \text { Area of Hanford Site } \\
50 \text { Inter-area transfer within } \\
\text { Hanford Site } \\
0 \text { Offsite }\end{array}$ \\
\hline
\end{tabular}


WHC-SD-WM-TA-160

Revision 0

Table F-1. Decision Analysis Objectives and Scales. (sheet 3 of 3 )

\begin{tabular}{|c|c|c|}
\hline Objective & Weight & Scale construction \\
\hline NEPA Permits & 0.108 & $\begin{array}{l}100 \text { Existing NEPA documentation } \\
\text { covers the proposed action. } \\
75 \text { A categorical exclusion is } \\
\text { required. Approximately } 3 \text { to } \\
4 \text { months to prepare. } \\
50 \text { An Environmental Assessment is } \\
\text { required. Approximately } 12 \text { months } \\
\text { to prepare. } \\
25 \text { A supplemental analysis to an } \\
\text { Environmental Impact Statement } \\
\text { (similar to EA) is required, } \\
\text { ionger to prepare than EA. } \\
0 \text { An Environmental Impact Statement } \\
\text { is required. Approximately } \\
36 \text { months to prepare. }\end{array}$ \\
\hline RCRA Permits & 0.108 & $\begin{array}{l}100 \text { RCRA approval in place within } \\
3 \text { months. } \\
67 \text { RCRA approval within } 3-9 \text { months. } \\
33 \text { RCRA approval within } 9-15 \text { months. } \\
0 \text { over } 15 \text { months to approve RCRA. }\end{array}$ \\
\hline Air Permits & 0.108 & $\begin{array}{l}100 \text { Air Permits approved within } \\
3 \text { months. } \\
67 \text { Air Permits approved within } \\
3-9 \text { months. } \\
33 \text { Air Permits approved within } \\
9-15 \text { months. } \\
\text { o over } 15 \text { months to approve Air } \\
\text { Permits. }\end{array}$ \\
\hline
\end{tabular}

$E A=$ Environmental Assessment

NEPA = National Environmental Policy Act of 1969

RCRA = Resource Conservation and Recovery Act of 1976

Weights depend on the ranges in performance over which the alternatives vary; an objective that has a narrow range will receive less weight than one that can significantly impact the alternative by changing the level of performance. In the process of developing the weights, ranges normally are considered in a "bottom up" process; in this case we had. only one level of objectives to consider.

The method that was used to determine the weights or the relative importance of the criteria is a standard decision analytic process known as "swing weighting," which ties the weights to range of the scales.

Some objectives would have had larger weights without the initial screening for minimum criteria because evaluators were concerned that certain criteria or objectives met minimum levels. Because the minimums were met, the concern was not as great for those objectives thus their importance or weight was proportionally smaller. 
WHC-SD-WM-TA-160

Revision 0

\section{F1.1.5 Overall Rating}

The overall evaluations of the "hot test" alternatives were obtained by rolling up all the individual parts for each alternative into a single number by which the alternatives can be quantitatively compared. The function used in this case was a linearly additive value function in which the assessed criteria weights were multiplied by the score (value) for each of the criteria for the particular alternative. A score of 100 would indicate a maximum score on all the criteria.

The evaluations for each technology issue group include the following (the references are to figures and tables in the main text of this report).

- A facility evaluation table for recording preselected scoring data about each of the candidate hot test facilities (Appendix D2).

- The criteria scoring of each facility and testing issue group (see Table 4-1, in the main report text).

- A graphical representation of the overall rating for the facilities (Figures 4-1 through 4-12).

- Performance Profiles for the highest ranked facilities for each issue group were prepared (those for the ion-exchange work will be shown in the following example).

The performance profile shows how an alternative's level of performance on the major objectives and the weight given to each major objective combine to produce that alternative's overall evaluation. The performance profile graph uses bar width to represent the weight while the height represents the alternative's performance on that objective. The profile shows how an individual objective contributes to the overall score for the alternative. The total area of all the bars is the alternative's overall value. These profiles show the relative strengths and weaknesses of each alternative.

- Sensitivity analysis of selected fundamental objectives.

A sensitivity analysis was performed to determine the robustness of the alternative rankings to changes in weighting (how the value of an alternative or testing facility varies based on changing the weight or importance of one fundamental objective). Thus insight into the effect of an individual objective on the overall performance rating is shown.

\section{F2.0 SITE EYALUATION}

Each alternative for each testing issue group was scored using the criteria established. The overall ranking for each testing issue group is displayed in Table 4-1 in the main text. To illustrate the evaluation and 
WHC-SD-WM-TA-160

Revision 0

sensitivity analysis process used on each testing issue group, the narrative below will discuss (1) the top ion-exchange hot test candidates and their performance profiles, and (2) the sensitivity of the rankings because of changes in measure weights. The sensitivity of the rankings regarding increases or decreases in importance of a measure were reviewed; one weight of a measure is increased (e.g., to $20 \%$ ) or decreased while holding the other measures at proportionally the same relative weight.

\section{F2.1 ALTERNATIVE EVALUATION FOR ION-EXCHANGE ISSUE CASE 1 GROUP 1}

\section{F2.1.1 Overal1 Ranking}

The result of the overall ranking (Tabie 4-1) shows $325 \mathrm{~A} \mathrm{C}, 325 \mathrm{~A} \mathrm{~B}$, and $325 \mathrm{~A} A$ as the top candidates (95) with 222-S(IF) (91), and 222-S(IEI) (91) in fourth and fifth positions.

\section{F2.1.2 Performance Profiles}

The performance profiles (Figures $F-1$ through $F-5$ ) for $325 A C, 325 A B$, and $325 \mathrm{~A} A$ indicate maximum scores for all measures except for Sample Transport. Hot Cell 222-S(IF) had maximum scores for all measures except for Availability, NEPA Permits, Analytical Equipment, and Professional Expertise. The 222-S(IEI) had maximum scores for all measures except NEPA Permits, analytical equipment, equipment access, hot cell size, and professional expertise measures.

\section{F2.1.3 Sensitivity Analysis}

Referring to Table 4-1 (main text), the top three candidates and 222-S(IF) are robust for changes in ES\&H, Air, NEPA, or RCRA Permit weightings (up to 20\%). The 222-S(IEl) surpasses 222-S(IF) when availability is weighted at $20 \%$. No change in the ranking results when measure weights are decreased to $4 \%$ for sample transport, $2 \%$ for analytical equipment, or $2 \%$ for services access. Increasing the weight for the sample transport measure to $20 \%$ moves 222-S(IF) and 222-S(IEI) to the first position. Decreasing the weight for the RCRA Permits measure does not change the original ranking.

\section{F2.2 TEST GROUP SITING RECOMMENDATION}

Upon completion of the above analysis for all testing issue groups, the combined site evaluation team met as discussed in Sections 4.3 and 4.3 .1 to perform the final facility assignments as presented in Table 4-2. 
WHC-SD-WM-TA- 160

Revision 0

Figure F-1. Performance Profile for 325A A.

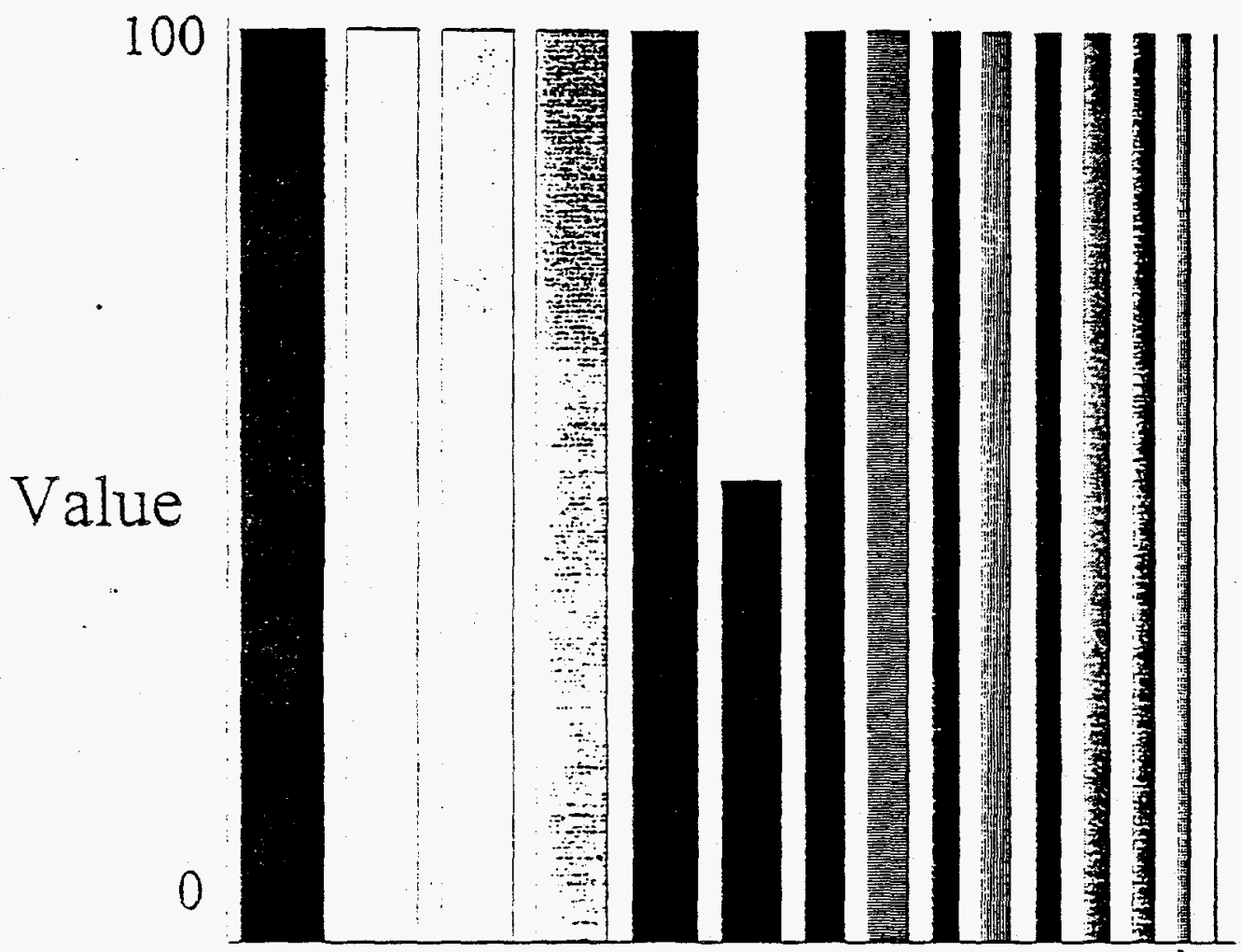

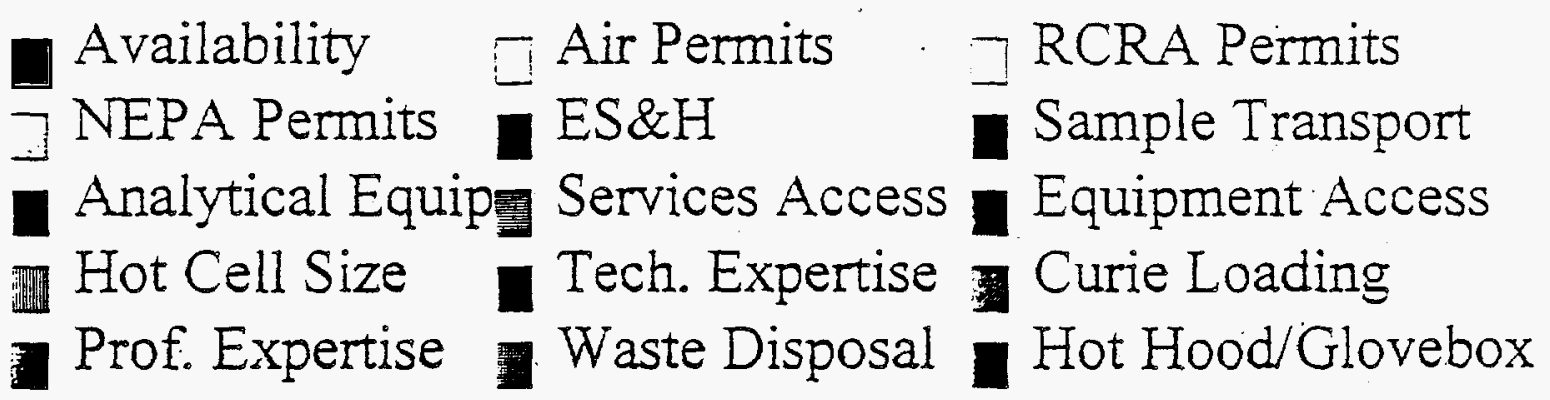


WHC-SD-WM-TA-160

Revision 0

Figure F-2. Performance Profile for 325A B.

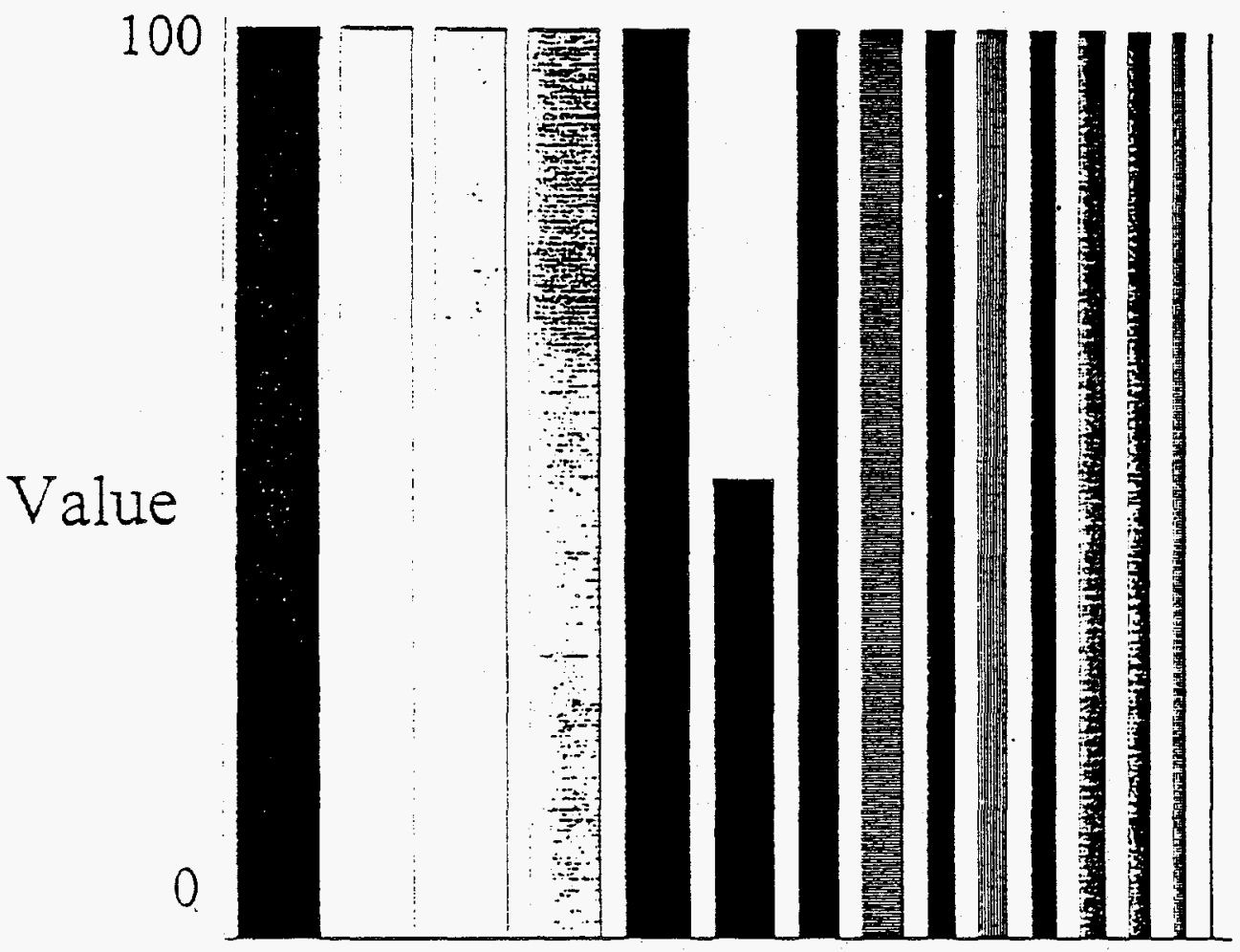

$\begin{array}{ll}\text { Availability } & \text { Air Permits } \\ \text { NEPA Permits } & \text { RS\&H Permits } \\ \text { Analytical Equip) Services Access } & \text { Equipment Access } \\ \text { Hot Cell Size } & \text { Tech. Expertise Curie Loading } \\ \text { Prof. Expertise } & \text { Waste Disposal }\end{array}$ 
WHC-SD-WM-TA-160

Revision 0

Figure F-3. Performance Profile for $325 \mathrm{~A} \mathrm{C}$.

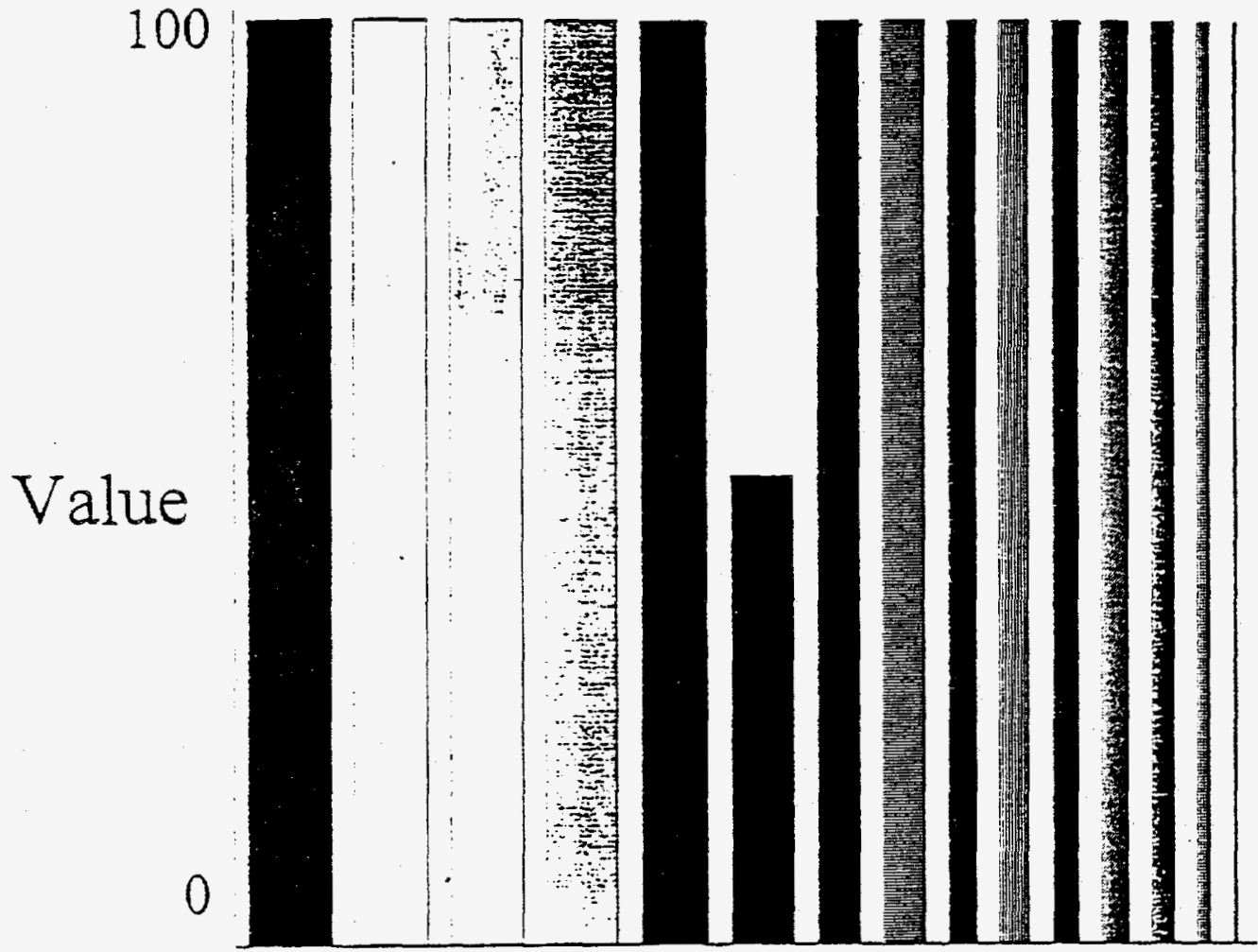

$\begin{array}{ll}\text { Availability } & \text { Air Permits } \\ \text { NEPA Permits } & \text { RCRA Permits } \\ \text { Analytical Equip } & \text { Services Access } \\ \text { Sample Transport } & \text { Equipment Access } \\ \text { Hot Cell Size } & \text { Tech. Expertise } \\ \text { Curie Loading } \\ \text { Prof. Expertise }\end{array}$ 
WHC-SD-WM-TA-160

Revision 0

Figure F-4. Performance Profile for 222-S(IF).

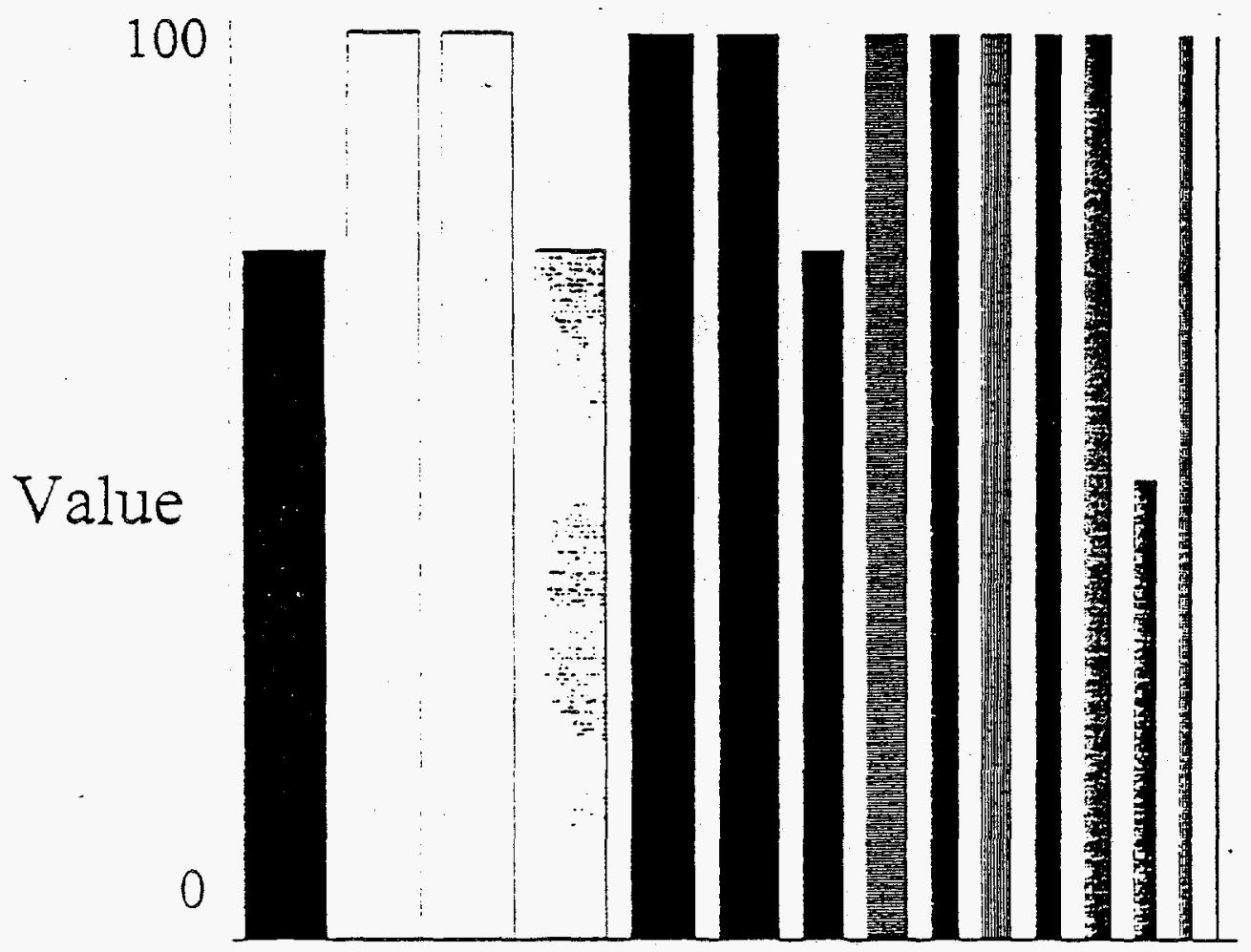

availability $\quad$ Air Permits $\sqsupset$ RCRA Permits

$\sqsupset$ NEPA Permits ES\&H

Analytical Equip

清 Hot Cell Size Tech. Expertise Curie Loading

Prof. Expertise Waste Disposal Hot Hood/Glovebox 
WHC-SD-WM-TA- 160

Revision 0

Figure F-5. Performance Profile for 222-S(1EI).

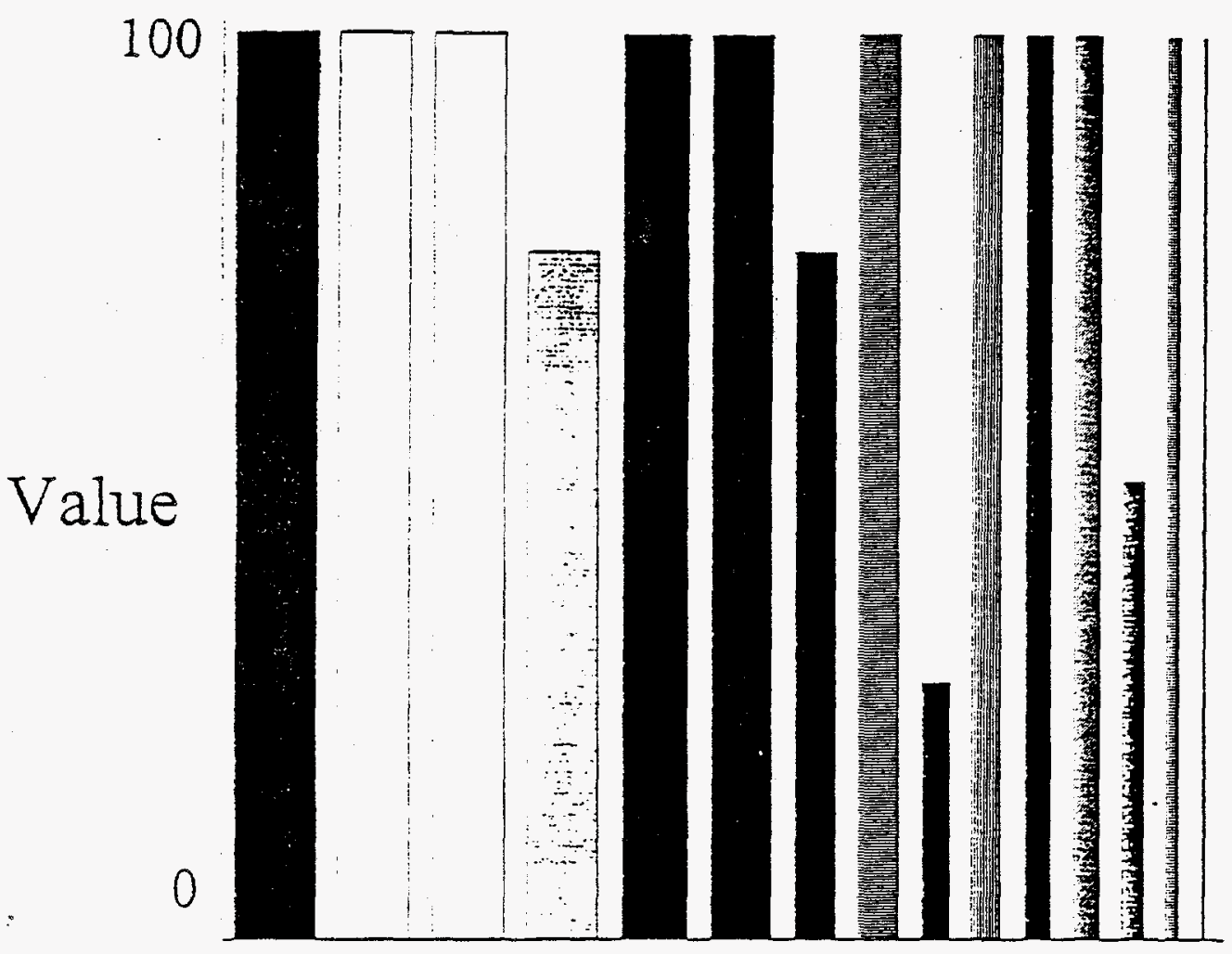

- Availability Air Permits $\square$ RCRA Permits

] NEPA Permits $\overline{\text { ES\&H }} \quad \overline{\mathbf{n}}$ Sample Transport

Analytical Equip

副. Hot Cell Size Tech. Expertise Curie Loading

3 Prof. Expertise a Waste Disposal Hot Hood/Glovebox 
WHC-SD-WM-TA-160

Revision 0

\section{F3.0 REFERENCES}

Keeney, Ralph L., 1992, Value Focused Thinking: A Path to Creative Decision Making, Harvard University Press, Cambridge, Massachusetts.

National Environmenta] Policy Act of 1969, 42 USC 4321, et seq.

Resource Conservation and Recovery Act of 1976, 42 USC 6901, et seq. 
WHC-SD-WM-TA- 160

Revision 0

APPENDIX G

RECORD OF KEY MEMORANDUMS

G-1 
WHC-SD-WM-TA- 160

Revision 0

\section{CONTENTS}

Meeting With States on Transportation of Hanford Tank Sample . . . . . G-3

PAS-1 Cask Maximum CS-137 Concentration . . . . . . . . . . . . . G-5

DOE Laboratory Compatibiljty with Tank Sample Casks . . . . . . . . . . . G-6

Testing Siting Final Report Notes . . . . . . . . . . . . . . . . G-7

Use of WESF Cells For IPM Process Development Testing . . . . . . . . . G-11

Transloading Waste Tank Samples for Off-site Shipment . . . . . . . . G-13 
[544] From: Curtis R Stroup at -WHC321 12/1/94 12:59PM (3273 bytes: 1 In, 1 f门)

To: Cary M Seide1, Steven M Joyce, Gary F Howden at "WHC97, David A Dodd at WHC121

Subject: MEETING WITH STATES ON TRANSPORTATION OF HANFORD TANK SAMPLE Message Contents

Text item. 1: Text_1

On November 9, 1994, a meeting was held to discuss the transportation of type A containers and the PAS-1 type $B$ cask, containing Hanford tank waste samples, from Hanford to INEL and LANL. Representatives (see attached 7 ist of attendees) from WHC Analytical Services Oregon Department of Energy (Ken Niles), Department of Energy, WHC transportation, and Washington State Patrol (Mr. Bill Bennett) attended the meeting.

Mr. Ken Niles and Mr. Bill Bennett felt that the packaging and transportation methods and rates ( 2 PAS-1 shipments per month) were acceptable. Mr. Ken Niles stated that he would discuss Hanford's transportation plans at the next western governors meeting. Mr. Niles felt that shipments of larger quantities than PAS-1 casks could carry would be an issue with the states. Mr. Niles also stated that he would discuss Hanford's transportation plans with the Umatilla Indians at his next opportunity. 
WHC-SD-WM-TA-160

Revision 0

$\begin{array}{lll}\frac{\text { NAME }}{\text { Curtis Stroup }} & \frac{\text { PHONE }}{509-372-0816} & \text { Analytical Tabs. } \\ \text { Paula Clark } & 509-376-4718 & \text { Dept. of Energy (Analytical Services) } \\ \text { Frank Votaw } & 509-376-7171 & \text { T \& P Haz. Mat. Operations } \\ \text { Sen Moy } & 509-376-8372 & \text { DOE Traffic Manager } \\ \text { Bill Bennett } & 206-783-0347 & \text { W. S. P. } \\ \text { Ken Niles } & 503-378-4906 & \text { Oregon DOE } \\ \text { Bill Irvine } & 509-376-5727 & \text { WHC Transportation \& Packaging } \\ \text { J. Greg Field } & 509-376-0781 & \text { WHC/TP/Packaging Safety Engineering } \\ \text { Richard J. Smith } & 509-376-9501 & \text { WHC/TP/Packaging Safety Engineering } \\ \text { Cary M. Seidel } & 509-375-0846 & \text { Analytical Labs. }\end{array}$


[517] From: David A Dodd at "WHC121 11/7/94 4:46PM (1812 bytes: 32 in)

To: PauT F Stevens at -WHC217, Gary F Howden at WHC97, Curtis R Stroup at WHC321

Subject: PAS-1 Cask Maximum Cs-137 Concentration

Text item 1: Text_1

Paut,

I think the feedstock that would be sent to the selected

site in the PAS-1 cask would be on the order of $1 \mathrm{Ci} / \mathrm{L}$. The

eluant off the loaded $\mathrm{Cs}$ column would reach the $50 \mathrm{ci} / \mathrm{L}$.

That product might have to be diluted for return to

Hanford in the cask. There would be no alpha in that material and therefore hydrogen generation should be negligible.

David Dodd

One of the criteria for the tank sample testing facility that was put forth at the meeting this morning was that they be able to accommodate tank samples with $\mathrm{Cs}-137$ concentrations up to $50 \mathrm{Ci} / 1$. I have reviewed the Safety Analysis Report (SAR) for the PAS-I cask, which would be used to ship the tank samples off the Hanford Site, at least in the initial phase of the campaign. Due to operational limits due to potential hydrogen generation, the maximum Cs-137 concentration that the cask can accommodate is $5 \mathrm{Ci} / 1$. The shielding analysis assumes a mixture of isotopes with the $\mathrm{Cs}-137$ concentration at $3 \mathrm{Ci} / 1$ (with 41 of samples).

As the SAR is written now, CS-137 $50 \mathrm{Ci} / 1$ samples must be dijuted. Future revisions may allow small tank samples with high Cs-137 concentrations to be shipped.

Paul Stevens

Packaging Safety Engineering 
WHC-SD-WM-TA- 160

Revision 0

[522] From: PauT F Stevens at WHC217 11/10/94 2:13PM (1901 bytes: 1 in) To: Gary F Howden at -WHC97, David A Dodd at -WHC121, Curtis R Stroup at -WHC321

Subject: DOE Laboratory Compatibility with Tank Sample Casks Message Contents

Text item 1: Text_1

When PSE started work on the revision of the PAS-1 cask SAR to include liquid shipments of up to 4 liters, they visited many of the DOE laboratory sites that you are considering for your testing campaigns to assess their ability to handle the cask. For INEL, ANL-E and the Hanford labs ( 325 \& 222S) we have data that indicates that they can handle the PAS-1 cask and sample containers. We do not have enough information on ORNL's facilities to make a positive judgment.

The PAS-1 cask maybe removed from its overpack outside the laboratory facility and transported into the facility with a dolly (the cask without overpack is approximately 1,900 (b). The laboratory facility must have the capability of removing the primary containment vessel from the PAS-1 (750 1b) and be capable of loading the shielded sample containers into the glove box (130 1b each, 7 in 00,13 in high).

If you have information the ORNL facility that might help me determine if it can handle the PAS cask, please let me know. Also, if you have a ORNL contact I could talk to, it would be greatly appreciated.

I will not be in the office tomorrow - if you have any information/news, please leave it with my secretary, Donna Rodgers (376-8772).

Paul Stevens

Packaging Safety Engineering 


\section{$11 / 22 / 94$ (Revised 11/23/94)}

Daity Team Meeting:

Attending: Bruce, Pat and Gary

Progress:

Pat reported on his investigation of the shipping cask question from the previous meeting:

Type A casks are shipped by common carrier and do not require dedicated trucks.

Type B casks are special haul on dedicated trucks. Cost is about $\$ 1.50 /$ mile.

\section{Discussion:}

Discussed ways/issues that would support combining some of the issues to reduce the total number of issues to be analyzed. A key issue was sample transportation. Called Curtis Stroup on speaker phone with following info from Curtis:

Curtis will write up a memo to file covering the discussions with the State of Oregon officials the week of $11 / 10 / 94$, including attendance list and will provide a copy by $12 / 1 / 94$.

Curtis says the understanding with the Oregon State representatives was that they would support two truck shipments per month across Oregon carrying two PAS-1 casks **. Curtis says it's very questionable whether they wouid consider a 50-100 liter cask.

Curtis' understanding is that the PAS-1 cask (which will be permitted to carry up to 4 liters of hi activity waste in January, 1995) can be redesigned to carry up to 8 liters/cask. That would require redesign of the inner. container and relicensing. Time to do so is estimated at 6 months to redesign and 3 months to relicense. With some aggressive work, Curtis believes the first of several new cask containers could be available for use in a total of 9-10 months from start of redesign.

A follow up call between Curtis and Gary provided the following guidance:

\section{Offsite shipping capability}

\section{Type A casks:}

Beginning January, up to $250 \mathrm{~mL}$ samples can be shipped to any national lab via common carrier. Have 2 Type A casks. (Twenty $10 \mathrm{~mL}$ and One $100 \mathrm{~mL}$ container Warthog) New Type A Hedgehog capabie of $10,100 \& 250 \mathrm{~mL}$ by May 95 . Expect 15-20 availabie) Retrieval via existing $250 \mathrm{~mL}$ sampler system and $10 \mathrm{~mL}$ grab sampler. Can support shipments of a maximum of 3 Type A $10 \mathrm{~mL}$ containers per 
month. (Lela Susaki has charge of archive sample inventory) George Stanton has charge of taking samples for TWRS pretreatment

Beginning February '95: Two PAS-1 casks, capable of 4 liters each, 16 liters per month. Retrieval via existing $250 \mathrm{~mL}$ sampler system, current plans are to keep $70 \mathrm{~mL}$ out of every $250 \mathrm{~mL}$ core sample leaving balance to go back to tanks or out for shipment. Expect to be taking about. (2 cores per tank) 300 to 400 core samples (not counting grab samples) in FY 95 . Out of 300 to 400 , we could get at best about 40 to 50 liters in year.

(A new strategy has been proposed to drasticaliy reduce the number of core samples taken. Takes about 20 shifts to take 2 cores. If the present coring program is reduced, Pretreatment could fund the coring crews to take core samples for us since they would be available or partially disbanded).

Beginning November/December '95: Two PAS-1 Casks *, capable of 8 liters each, 32 liters/month based on current agreements with Oregon. Retrieval based on current projections would net about 60 liters during the year or 30 liters the first half of $\mathrm{CY} 96$ that could be shipped to other sites.

Beginning July/September 196: Two or more PAS-1 Casks *, capable of 8 liters each, at least 16 liters/month with the 25 liter sampler system operational to provide retrieval and 222 lab support + for repackaging.

\section{Footnotes:}

* Al1 containers procured with Characterization funds. Characterization would have first priority if require. Procurement of additional PAS-1 casks has a lead time of about 5 months at a cost of $\$ 150 \mathrm{~K}$ each, the Hedgehog Type A will be 3.5 months lead time At \$10-15K each in quantity.

+ Curtis is going to call Jim Mullally in Bazinetts group to set up a meeting to discuss the SRP 25 liter coring device and scope what will be required to interface it with the 222 lab facility.

** Assumes all other states might fall in line with Oregon, which is probably not true. 
Testing Siting Final Report Notes (Cont'd)

$11 / 23 / 94$

Daily Team Meeting:

Attending: Bruce, Pat, Rudy, Gary

Next Meeting: Monday $11 / 28 / 94$ at 10AM Raytheon B1d

\section{Progress:}

Bruce finished the data sheets for the 222 labs and passed to Pat for review. Gary reviewed and discussed the sample shipping limitations described above.

\section{Discussion:}

Discussed ways to reduce the number of alternatives to be considered. Continuing site assessment will be done based on the following "rules" and screening criteria:

Rule \#1) Work on an issue will not be split between sites, that is, when an issue requires a combination of cold and hot testing, the work will all be done at the same site. The basis for this rule is avoidance of data correlation problems, reduced coordination and administration.

Rule \#2) Issues that can use the same radioactive waste sample(s) for resolution will be combined/grouped and will not be split between sites. The basis for this rule is avoidance of unnecessary shipping of radioactive waste samples.

Rule \#3) Issues that require an elaborate/costly hot 1 ab or hot cell set up and can be resolved on the same set up as another issue(s) will be combined/grouped. The basis for this rule is avoidance of unnecessary test apparatus/set up cost. The guidance for this rule is costs over $\$$ 25K per set up.

Continuing site assessment will also be subject to the following two Go-No-Go screening criteria on an issue by issue basis. Failure on one or both will be the basis for not spending time preparing detailed assessment data sheets for the issue at that site.

Question A) Can WHC ship the identified schedule of tank waste to the site in time to for the site to meet the $A-E$ schedule?

Question B) Are there conditions at the candidate site that would preclude it from consideration?

B-1) Cell or hot lab unavailable

B-2) Staff commitment 
WHC-SD-WM-TA- 160

Revision 0

8-3) Some indication a state would not allow waste shipment to that site

B-4) Time to obtain needed operating permits for the site facifity

B-5) DOE directive/guidance 
WHC-SD-WM-TA-160

Revision 0

\section{MEETING MINUTES}

Subject: Use of WESF Cells For IPM Process Development Testing

TO: Distribution

BUILDING: See Distribution

FROM: Gary Howden

CHAIRMAN: R. R. Gadd

\begin{tabular}{|c|c|c|c|}
\hline $\begin{array}{l}\text { Dept-Operation-Component } \\
\text { TWRS/Projects/IPM Project }\end{array}$ & $\begin{array}{l}\text { Area } \\
200 E\end{array}$ & $\begin{array}{ll}\text { Shift } & \text { Meeting Date } \\
\text { Day } & 10 / 3 / 94\end{array}$ & $\begin{array}{l}\text { Number } \\
\text { Attending } \\
8\end{array}$ \\
\hline $\begin{array}{l}\text { Distribution: } \\
\qquad \begin{array}{l}\text { B Plant/WESF } \\
\text { W. W. Bowen } \\
\text { R. E. Heineman Jr } \\
\text { D. K. Smith }\end{array}\end{array}$ & $\begin{array}{l}S 6-65 \\
S 6-65 \\
S 6-65\end{array}$ & $\begin{array}{l}\text { IPM Project } \\
\text { D. L. Banning } \\
\text { S. A. Barker } \\
\text { R. R. Gadd } \\
\text { G. F. Howden } \\
\text { R. V. Vaddey }\end{array}$ & $\begin{array}{l}G 3-20 \\
G 3-20 \\
G 3-20 \\
G 3-20 \\
G 3-20\end{array}$ \\
\hline
\end{tabular}

The meeting was called to identify issues that must be assessed to provide a recommendation to WHC senior management and DOE/RL on the use of " $B$ " through " $E$ " window cell work stations in WESF for a two year process development testing mission in support of the design of the Initial. Pretreatment Module (IPM).

R. R. Gadd opened the meeting with a statement of the IPM Projects objective to find a compatible location for performing pretreatment process development. The test will be a treatability study that has a maximum throughput requirement. An RD \& D permit would allow greater throughput, but would take much longer to obtain.

It was also noted that this test work would be completely self contained within the WESF cells and would not require rad waste transfers through or to B Plant. A French shielded transporter being procured by the Tank Farms Maintenance \& Operations organization would be used to move tank waste samples to WESF and remove the test effluents.

R. E. Heineman indicated that the program for the return of cesium and strontium capsules from several offsite locations is their primary mission and carries a high priority with DOE/HQ and DOE/RL and a lot of public visibility. He identified the following points for assessment in development of a recommendation on use of WESF for the added testing mission: 
WHC-SD-WM-TA-160

Revision 0

Page 2 of

\section{Mission Related Issues:}

1. Are there basic incompatibilities in the use of the facility for an operational mission of capsule storage \& maintenance, and a testing mission of chemical process development in support of the IPM Project design?

2. What are the risks to the capsule return and storage mission of giving up $4 / 7$ ths of the available cell work station space.

Operational Issues:

1. What added demands would the pretreatment testing mission make on the capsule recovery mission resources, space and personnel.

2. What effect would a joint mission have on the capsule recovery missions emergency response capability?

3. What effect would a joint mission have on the recovery and repackaging of residual $\mathrm{CS}$ and $\mathrm{Sr}$ stored at other hot cell facilities?

4. Cell cleanout and modification would take place in 7 ate CY 95 and early cy96. Testing would start in mid-1996. Would the test program interfere with the capsule return program?

Safety and Permitting Issues:

1. What would be the impact on existing safety and environmental permitting of a joint mission?

2. The work to isolate WESF from B Plant is expected to be complete in CY 95. Would this impact the cell clean-up and installation of test equipment?

Schedule Issues:

1. B Plant/WESF Management is planning on starting design of a capsule re-encapsulation capability in FY-96. Would performance of the $1-2$ year test (starting in mid $C Y 96$ ) effect the development of this capability? If so, are there work-arounds?

Conciusion:

Kent Smith will continue as the primary interface with the IPM Project and will work with the Project staff on resolution of the above issues.

A ground rule for the assessments is that we cannot delay the capsule return shipments and on-site handling.

As of $10 / 26 / 94$, RL has placed any further action on use of WESF for IPM Project testing on hold pending resolution of budget and test sizing issues. We will advise when this hold is lifted. 
WHC-SD-WM-TA-160

Revision 0

December 21, 1994

TO: G.F.Howden

FROM: D.A. Dodd

Subject: Transioading Waste Tank Samples for Off-site Shipment

There is currentiy only one cask type, PAS-I, approved for use in shipping liquid and solid, Hanford waste tank materials to off-site locations. This cask is not conducive in its present configuration for loading in the tank farm area. Samples are currently brought to the 222-S Laboratory, composited into predetermined quantities in primary containers, and loaded into the cask. Shipping and manifest documents are prepared and arrangements are made through WHC Transportation for shipment. Each shipment requires a significant effort to coordinate and document.

Questions have been raised concerning the ability and willingness of 222-S Laboratory to perform this transloading activity if off-site facilities are chosen as the location for conducting tests necessary to design the Pretreatment Process Facility. In response, the 222-S Laboratory is willing to provide support to this effort as long as the primary function/mission of the laboratory, analyses of samples, is not jeopardized. If this activity is to continue for the duration of testing, 3 years, a special handling location within the building will be established. This segregation of work activities would then interject minimum perturbations to the production mission.

A stipulation is imposed however, no major modifications to the facility be required to accommodate the activity. This precludes the transloading of 25 liter samplers but lesser volume samplers, e.g. $3 \mathrm{~L}$, $500 \mathrm{~mL}$, can be accommodated. Major modifications would be required to move the $>8$ ton cask, to mate the cask to the hotcell for shielding during entry of the sampler into the hotcell, to move and empty the weight of the sampler, and to clean the sampler for reuse.

Modifications necessary for this activity could not be completed within the time frame of the testing unless extraordinary priority were placed on them. Placing appropriate priority would adversely impact other production activities in the facility. 
WHC-SD-WM-TA- 160

Revision 0

This page intentionally left blank.

G-14 